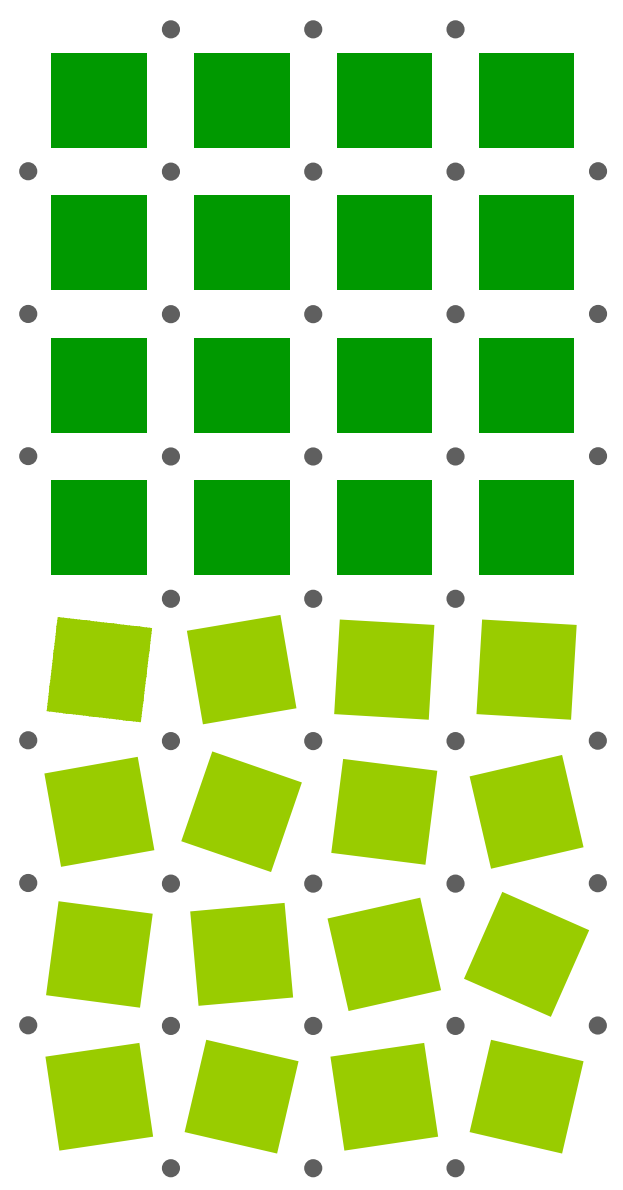

\title{
Paisagem e
}

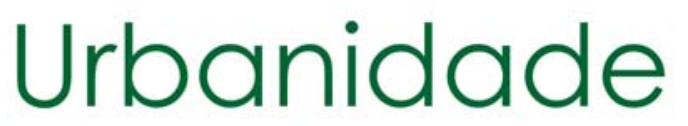

Os limites do projeto urbano na conformação de lugares em Palmas

Tese de Doutorado

Glauco de Paula Cocozza

Orientadora

Profa. Dra. Catharina Pinheiro

Cordeiro dos Santos Lima

Universidade de São Paulo

Faculdade de Arquitetura e Urbanismo

Paisa gem e Ambiente

São Paulo

2007 


\title{
Paisagem e Urbanidade
}

Os limites do projeto urbano na conformação de lugares em Palmas

\author{
Glauco de Paula Cocozza
}

Tese de Doutora do a presentada à Faculda de de Arquitetura e Urbanismo da Universida de de São Paulo para obtenção do título de Doutor em Arquitetura e Urbanismo

Área de Concentração: Paisagem e Ambiente

Orientadora: Profa. Dra. Cathanina Pinheiro Cordeiro dos Santos Lima 
AUTORIZO A REPRODUÇÃO E DIVULG AÇÃO TOTAL OU PARCIALDESTE TRABALHO, POR QUALQUER MEIO CONVENC IONAL OU ELEIRÔNICO, PARA FINSDE ESTUDO E PESQ UISA, DESDE QUE CITADA A FONTE.

E-MAlL: gcocozza@uft.edu.br/glauco_cocozza@yahoo.com.br

Cocozza, Glauco de Paula

C667p Paisagem e urbanidade: os limites do projeto urbano na conformação de lugaresem Palmas / Glauco de Paula Cocozza. --São Paulo, 2007.

253 p. : il.

Tese (Doutorado - Área de Concentração: Paisagem e Ambiente) - FAUUSP.

Orientadora: Catharina Pinheiro Cordeiro dos Santos Lima

1.Espaços livres 2.Espaç̧o público 3.Espaço urbano - Projeto 4.Pa Imas (TO) I.Título

CDU 712.25 
Dedico este trabalho a quem está para chegar.... 


\section{Agradecimentos}

Agradeço,

Primeiramente a Liliane, que até o último momento me deu forças para que eu pudesse tê-lo concluído;

a minha família, que soube me apoiarem todasas decisões;

a Catharina Lima, que me inspira na arte de ensinar,

aos professores das disciplinas da FAU-USP, Jorge Oseki, Paulo Pellegrino, Euller Sandeville e Heliana Comin Vargas;

a Manoel Rodrigues Alves e Carlos Roberto Monteiro Andrade, da EESC, que na fase final dessa jomada proporcionaram novas visões sobre o urbano; aos professores e colegas do curso de Capacitação em Arquitetura Pa isa gístic a, pessoa s incríveis que tra nsmitira m novos conhec imentos; aos colegas de Votuporanga, que em discussões informa is me ajudaram a desenvolver esse tema;

aos professores do curso de a rquitetura e à UFT, que possibilitaram uma maior dedicação a este trabalho;

a Luiz Hildebrando, César de Santis, Daniela Fighera, Simone, Chiquinha, e a todas as pessoas da SEDUH, SEMUC e ADTO, que me ajudaram nessa pesquisa;

a Walfredo Antunes, que em longas conversas me fez compreender um pouco mais sobre a cidade que projetara;

a Raul Pereira e aos novos amigos da a rquitetura paisagística, que batalham por uma nova paisagem nascidades;

a Neuza, Dalva e dona Cissa, pessoasque aprendi a admirar; a o aluno Daniel Pimentel, que me apresentou à sua Vila União;

aosalunos do curso de arquitetura Reyffere Geórgia;

aos velhos e novos amigos de São Carlos, cidade que novamente esteve presente em minha trajetória acadêmica;

aos novos amigos de Palmas;

e, finalmente, a todos os a nônimos que ajudaram a construir o meu objeto de pesquisa. 


\section{Res u mo}

Na recente histónia urbana, Palmas, a mais nova cidade planejada brasileira, se depara na atualidade com questões e conflitos que mesmo o planejamento urbano não conseguiu evitar. Este trabalho identifica a gênese urbana da Vila União, região de Palmas na qual o determinismo do plano confronta com formas espontâneas de apropriação, e cria uma nova face na conformação de lugares. Seu processo de ocupação construiu um espaço urbano específico, resultando em uma outra urbanidade. A contestação identitária configurou sua qualidade espacial, caracterizada pela esfera pública da vida cotidiana.

A hipótese central que permeia este trabalho é que os lugares conforma dos nos limites entre o projeto urbano e os processos soc ia is, são os principais promotores dessa nova urbanidade. A dualidade entre urbanismo e urbanização proporcionou um caráter híbrido à cidade, evidenciando os processos cultura is de construção do espaço. 


\section{A bstract}

In the recent urban history, Palmas, the newest Brazilian planned city, actually confront many questions that even the urban planning cannot avoid. This work aims identify the morphological genesis of Vila União, a neighborhood unity in Palmas, where the determinism of the plan confront with the spontaneous appropriations forms, and create a new face in the constitutions of places. Your occupation process built a specific urban space, resulting in urbanity. The identitary contestation configured your spatial quality, characterized by the public sphere of quotidian life.

The central hypothesis that permeates this work is that places conformed between the urban design and the social process, are the principal urbanity promoters. The dua lity between urbanism and urbanization provides a hybrid character to the city, making evident the cultural process to built space 


\section{Lista de Figuras}

Fig. 01 Modelo de Unida de de Vizinhança de Pery............................................ 62

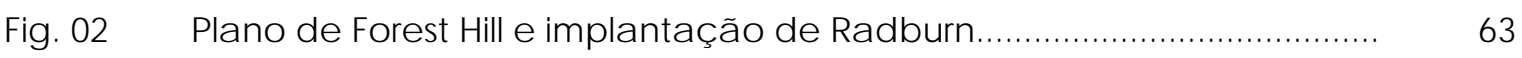

Fig. 03 Unidade de Vizinhança de Brasília ............................................................ 66

Fig.04 Plano piloto da TOD e detalhe de seu centro comercial............................ 68

Fig. 05 Organização dos espaços livres e área comercial: TOD............................ 69

Fig. 06 Ruase calçadas; Ruas atrás dascasas.................................................. 70

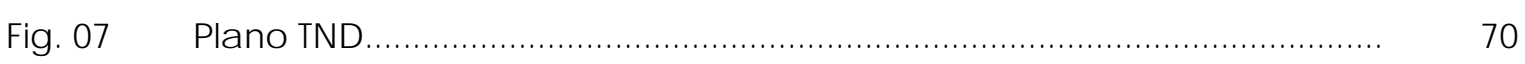

Fig. 08 Modelo centralizado e multifocal............................................................. 77

Fig. 09 Planta de Roma mostrando as a venidas abertas por Sisto V.................... 78

Fig. 10 Abertura dasavenidas em Paris e projeto de Washington....................... $\quad 79$

Fig. 11 Viena antes de depois de sua intervenção urbana.................................... 80

Fig. 12 Estudo da axialidade da trama urbana de Londres................................ 81

Fig. 13 Esboço da conectividade de fluxospara o espaço................................... 82

Fig. 14 Fluxos e concentração de pessoas na Trafalgar Square, Londres............ 84

Fig. 15 Relação entre espaço livre e edificação nas superquadras de Brasília.. 85

Fig. 16 Piazza San Marco e Piazza del Campo..................................... 86

Fig. 17 Modelo que nega as interfacese modelo urbano com interfaces.......... 87

Fig. 18 Sistemas de espaços livres em Roma e na cidade de La Plata............... $\quad 87$

Fig. 19 Plano de Cerda para Barcelona ..................................................................... 88

Fig. 20 Maquete de uma quadra de Barcelona .................................................... 88

Fig. 21 Sistema de Espaços livres em um projeto de uso urbano de uso misto.... $\quad 89$

Fig. 22 Mapa da localização do Estado do Tocantinse da cidade de Palmas. $\quad 94$

Fig. 23 Localização da cidade entre a Serra e o futuro Lago.............................. 95

Fig. $24 \quad$ Plano de Chandigarh e de Palmas......................................................... 97

Fig. 25 Perspectiva geral do plano de Palmas....................................................... 98

Fig. 26 Modelo de Unidade de Vizinhança de Pemy e de Palmas........................ 99

Fig. 27 Praça dos Girassóis: marco iconográfico da cidade.................................. 106

Fig. 28 Áreas de preservação e proteção de Palmas............................................ 108

Fig. 29 Áreas de Conservação propostaspelo Novo Plano Diretor de Palmas... $\quad 108$

Fig. 30 Espaço livre utilitário da cidade: Avenida Teotônio Segurado................. 109

Fig. 31 Chegada a Palmas - Iníc io dasobras........................................................ 110

Fig. 32 Processo de implantação e urbanização da Cidade................................. 111

Fig. 33 Perspectiva da cidade na apresentação do projeto................................. 112

Fig. 34 Etapas de crescimento da cidade até o ano de 2010............................. 113

Fig. 35 Ocupação da cidade a té 2002............................................................. 114 
Fig. 36 Tabela de custos totais de serviços urbanos.

Fig. 37 Morfologia do Plano de Palmase Morfologia atual da cidade.....

Fig. 38

Projeto para as primeiras quadras de Palmase Quadra ARSE 51.

116

Fig. 39

Primeira Missa Campal na Praça dos Girassóis..

118

Fig. 40

Aspecto da Praça dosGirassóis no início de Palmas......

119

Fig. 41

Processo de idealização e fase da construção da Praça dos Girassóis..

119

Fig. 42

Aspec to inicial e atual da Praça dos Girassóis.

120

Fig. 43

Aspec to inicial do Paço Municipale do Bosque dos Pioneiros..

121

Fig. 44

Antiga Praia da Graciosa quando a inda no Rio Tocantins.

121

Fig. 45

Orla da Graciosa no Lago construído no Rio Tocantins.

122

Fig. 46

Apropriação das Margens do Lago: Praia do Prata e da Amo

123

Fig. 47

Loca lização da cidade e projeto do Parque Cesamar..

126

Fig. 48

Osjardins como imagem da cidade

127

Fig. 49

Abertura da Avenida Teotônio.

128

Fig. 50

Trecho da Avenida com o Palácio Araguaia a o Fundo.

129

Fig. 51

Croqui do Grupo 4 ilustrando o contexto urbano e paisagístic o

129

Fig. 52

Primeira foto: trec ho totalmente devasta do da avenida.

131

Fig. 53

Ocupação do J a rdim Aureny em 1994

133

Fig. 54

Área do Palacinho no início de Palmas.

134

Fig. 55

Limites definidos pelo desenho.

135

Fig. 56

Primeiras construções da Vila União

136

Fig. 57

Detalhe de Casa com o logotipo do J oão de Barro.

136

Fig. 58

Primeiras construções da Vila União

137

Fig. 59

Plano de Palmase detalhe das três quadras que compõem a VU..

138

Fig. 60

Loc a liza ção das Feiras 304S (AESE 31) e 307N(ARNO 33).

140

Fig. 61

Cenas do Mercado da 307N em uma manhã de domingo

141

Fig. 62

Cenas do cotidiano nas ruas da Vila União.

Fig. 63

Princípio de divisão da malha das quadrascom seus acessos.

148

Fig. 64

Loca lização da Vila União e Quadras Centra is.....

149

Fig. 65

Mapa de Densidade Populacional de Palmas.

150

Fig. 66

Mapa de ocupação Temitorial da Cidade de Palmas.

151

Fig. 67

Mapa de uso proposto para a Vila União

Fig. 68

Projeto diferenciado para a ARNO 32.

153

Fig. 69

Quadra de Palmascom marcas impressas no espaço.

Fig. 70

Vila União seguindo as premissas de sua conformação

Fig. 71

Horta comunitária da Amo 33 gerida pela comunidade local...

Fig. 72

Quadras Centra is seguind o premissas do plano 
Fig.73 Quadras Centra is na atua lidade....

Fig. $74 \quad$ Imagem síntese daspropostas elaboradas no Pla no Diretor de Palmas.

Fig. 75

Plano diretor da cidade com as "áreas" pré-estabelecidas.

Fig. 76

Duas principa is centra lidades: Palmas Centro e Taquaralto.

Centralidades da Arse 13.

Fig. 81

Centralidade da Arse 14 - comércio junto a Praça

Praça da Arse14 em uma terça-feira à tarde.

Fig. 105 Praça da Amo31(a primeira quadra da Vila União) terça-feira à tarde.. 
Fig. 110 Movimentose permanências na Área Central a na Vila União.....

Fig. 111 Amo 33 domingo pela manhã ................................................................. 195

Fig. 112 Espaços priva dos e espaç os livres das quad ras c entra is............................ 199

Fig. 113 Praça da Arse14....................................................................................... 199

Fig. 114 Muros dos lotes residencia is que limitam o espaço público do privado.. 201

Fig. 115 Calçadasque não promove urbanidade.................................................... 202

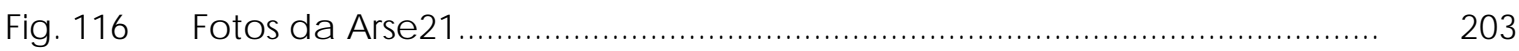

Fig. 117 Espaços privadose livres da Vila União....................................................... 204

Fig. 118 Espaços edificadose não ed ificados das quadrascentra is..................... 204

Fig. 119 Cenários do cotidia no da Vila União............................................................. 205

Fig. 120 Áreas edific adase não ed ific adas da Vila Uniã o...................................... 206

Fig. 121 Relação entre a escala da arquitetura e do espaço livre.......................... 206

Fig. 122 Transfomação e manutenção dascaracteństic as edilícias: Vila União.. 207

Fig. 123 Barreiras existentes na região central.......................................................... 209

Fig. 124 Barreiras no espaço das quadras centra is................................................... 210

Fig. 125 Foto aérea da praça central da Arse12................................................. 211

Fig. 126 Interfac es existentes nas quad ras centra is............................................... 212

Fig. 127 Interfaces que oc orrem nas quadras centra is......................................... 213

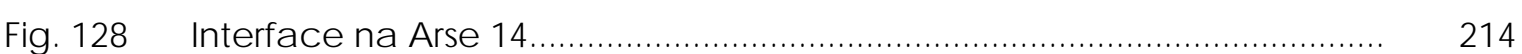

Fig. 129 Barreiras na Vila Uniã o.......................................................................... 215

Fig. $130 \quad$ Barreiras na Vila União o.................................................................... 215

Fig. 131 Interfaces na Vila União ..................................................................... 216

Fig. 132 Foto aérea da entra da das Quadras Amo 32 e 33.................................. 216

Fig. 133 Detalhe de interfaces na Vila União...................................................... 217

Fig. 134 Diferentes momentos do paisa gismo dos canteiros e rotatórias............... 219

Fig. 135 Pa isa gem das a venida s a rteria is na regiã o central.................................. 219

Fig. 136 Espaços verdes na á rea central............................................................ 220

Fig. 137 Caracterizaçã o dos de Espaços livres Verdes na regiã o central.............. 220

Fig. 138 Espaços verdes tota Imente modific ados: região centra I.......................... $\quad 222$

Fig. 139 Espaç os verdes pertencentes a o sistema viá rio de Pa Imas....................... 222

Fig. 140 Canteiros centra is e passeio de pedestres na Arse14................................ 223

Fig. 141 Espaços verdes que sofreram intervenção projetual................................. 224

Fig. 142 Área da Praça da Arse12 sem intervenção com as espéciesnativas..... 224

Fig. 143 Praça da Arse13 com sua vegetação nativa incorporada ao projeto... 225

Fig. 144 Espaços verdes que não sofreram intervenção projetual......................... 226

Fig. 145 Espaços verdes sem intervenção projetual................................................ 227

Fig. 146 Arborização da quadra central............................................................... 227 
Fig. 147 Arborização nascalça das da região central............................................. 228

Fig. 148 Arborização na Vila União o...................................................................... 229

Fig. 149 Arboriza ção nos lotes partic ula res da Vila União........................................ 229

Fig. 150 Caracterização dos Espaços Verdes na Vila Uniã o..................................... 229

Fig. 151 Espaços verdes modific a dos e com nova vegetação................................ 230

Fig. 152 Canteiros centra is da s a venida s......................................................... 230

Fig. 153 Espaços livres verdes que sofreram intervenção projetual........................ 231

Fig. 154 Praça central da Amo 33......................................................................... 231

Fig. 155 Espaços livres verdes parcia Imente modifica dos...................................... 232

Fig. 156 Cenas do cotidiano e dos espaços livres sem intervenção projetual...... 233 


\section{Lista de símbolos, abreviatura e siglas}

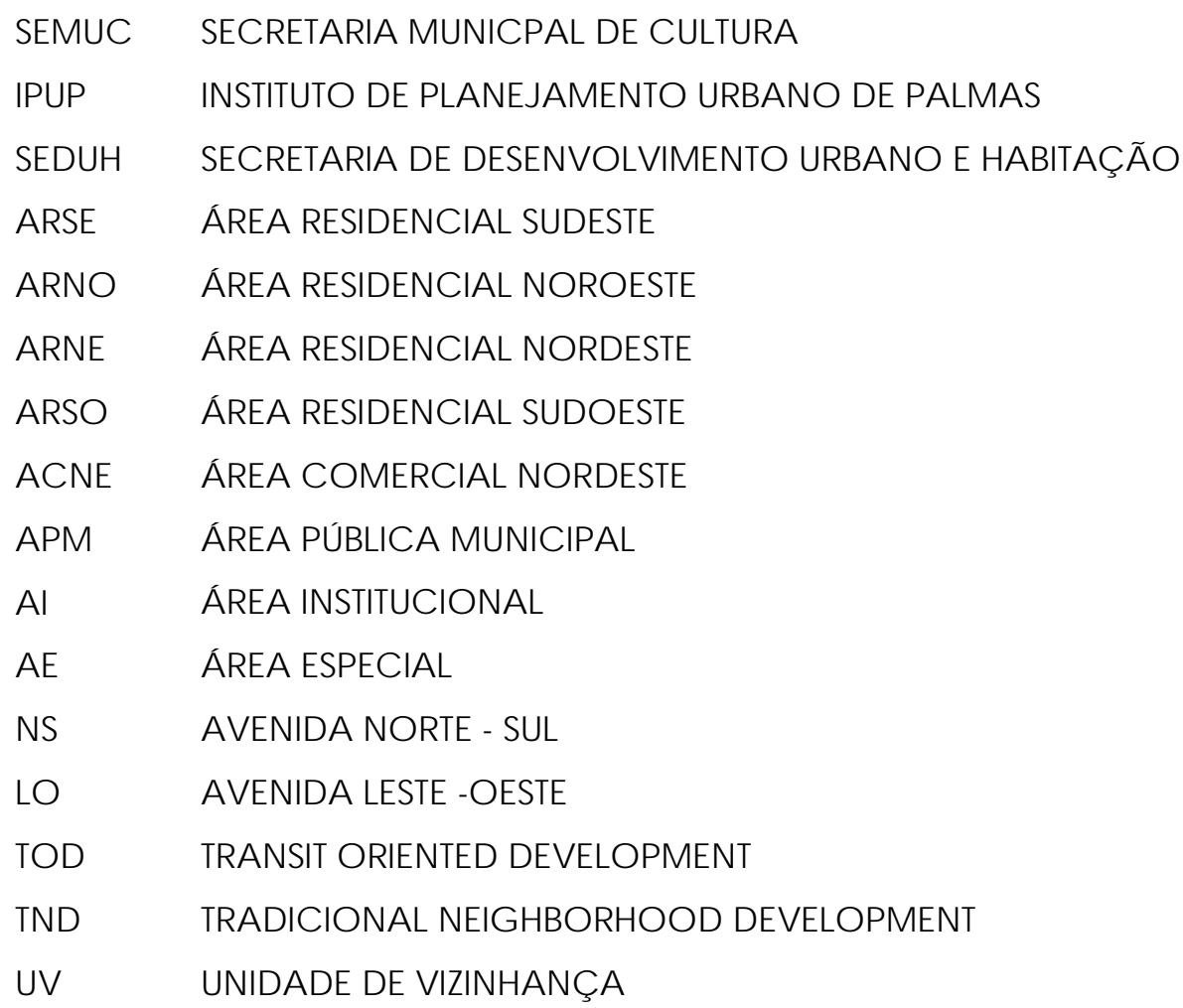




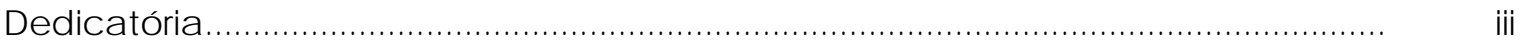

Agra dec imentos.............................................................................................. iv

Resumo

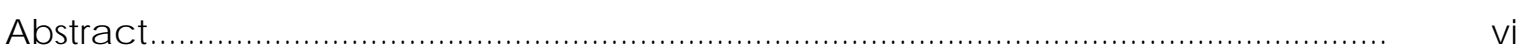

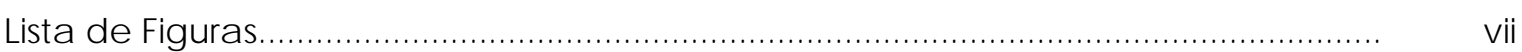

Lista de Símbolos, Abreviaturas e Siglas....................................................................... xii

\section{S U M Á R I O}

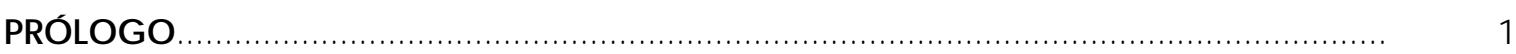

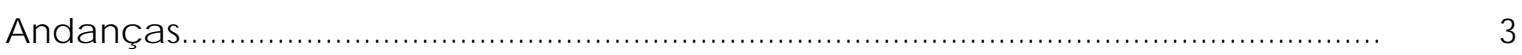

INTRODUÇÃO................................................................................................................

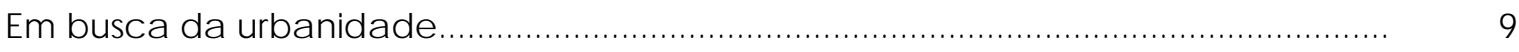

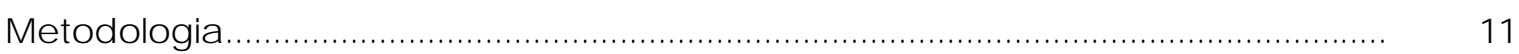

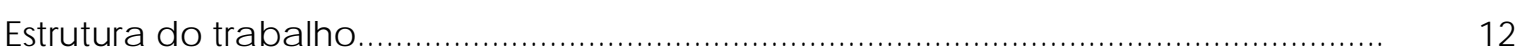

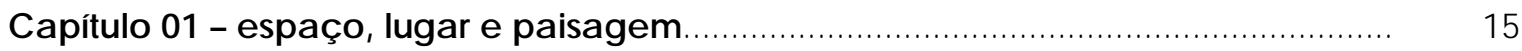

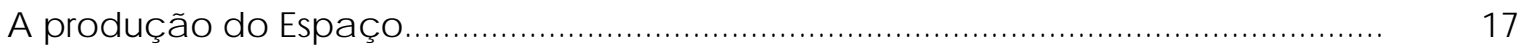

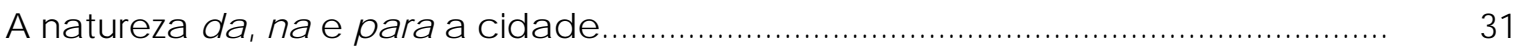

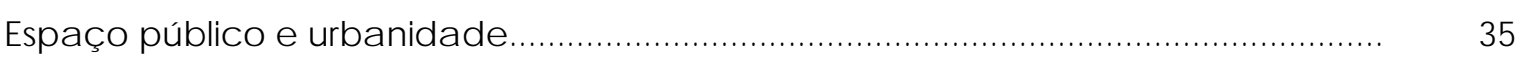

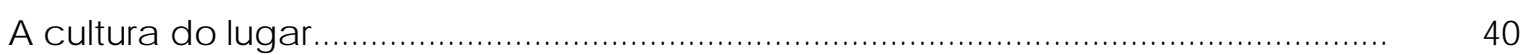

A ordem da desordem - os usos do cotidiano .......................................................... 45

A c ultura e o lugar na contemporaneida de ............................................................. 52

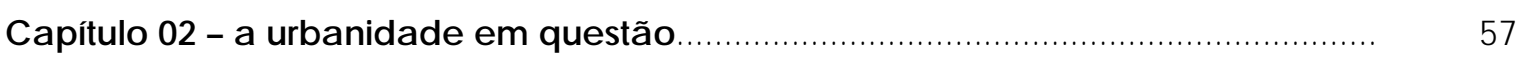

Utopias e limites do projeto urbano ......................................................................... 59

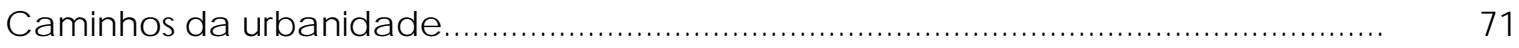

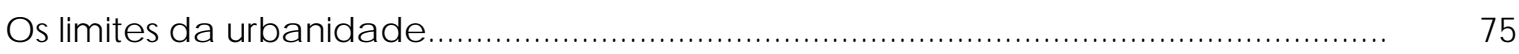

Capítulo 03 - inscrições no espaço de Palmas.......................................................... 91

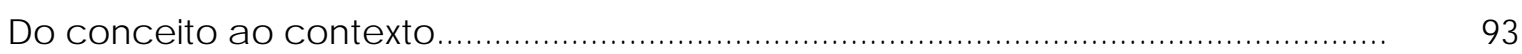

A gênese do urbanismo de Palmas......................................................................... 97

Os luga res a ntes e depois da ponte....................................................................... $\quad 100$

Espaço e Paisa gem em Pa Imas................................................................................. 101

Do plano a cidade real: os limites do projeto urbano.............................................. 103 


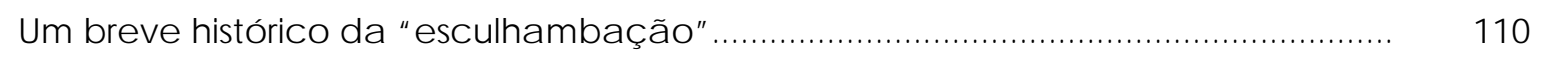

A formação e transformação dos espaços públic os de Pa Ima s.................................. 118

Do contexto a o lugar - dimensões da paisagem na Av. Teotônio .............................. 128

As inva sões bárbaras............................................................................................... 132

Vila União: um bairo dentro do plano..................................................................... 134

Quando o mercado vira praça e a praça vira mercado........................................... 139

Capítulo 04 - os limites do projeto urbano na conformação de lugares.................... 145

As categorias de a ná lise.................................................................................... 147

Fragmentos de uma cidade real.......................................................................... $\quad 148$

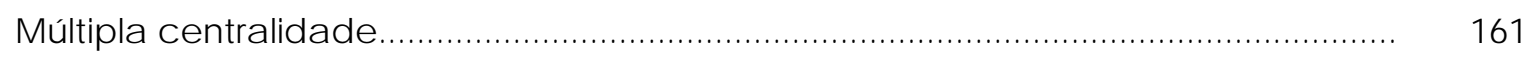

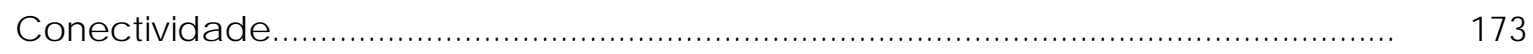

Movimento e permanência no espaço................................................................... 184

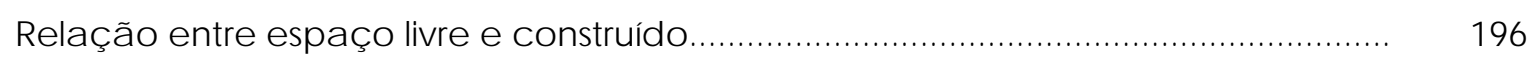

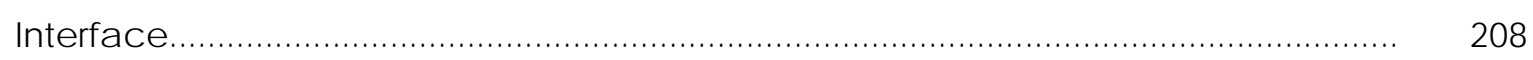

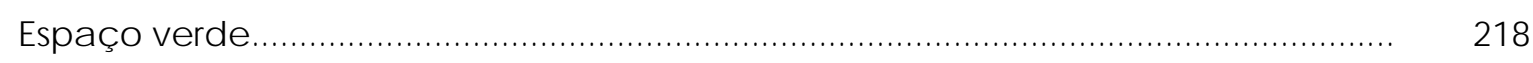

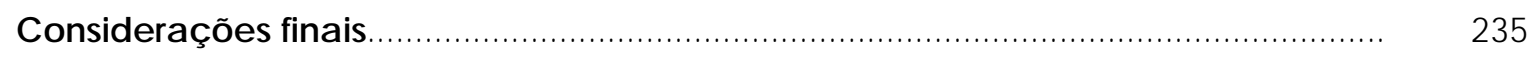

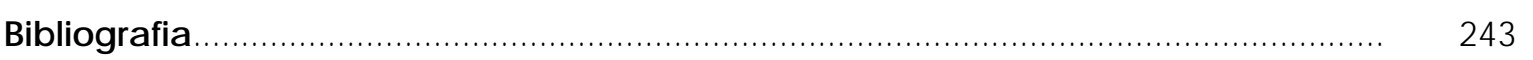




\section{A n d a n ç a s}

Ainda me lembro de minha época de começo do curso de arquitetura no Mackenzie, isso em 1993, quando um amigo me convidou para ir a Palmas junto com outros colegas do curso, a mais nova cidade planejada Brasileira e que estava em plena construção. Lembro-me de uma aula de um professor falando sobre o plano da cidade, mas para mim, Goiás, Tocantins, ainda eram locais desconhecidos de minha noção ainda pequena de Brasil, que se limitava ao sul e ao sudeste brasileiro, e a algumas viagens para o nordeste em família quando garoto.

Não fui a essa viagem, uma pena, mas recordo das pessoas a o regressar de lá relatando as aventuras e os fatos pelo qual haviam passado, muitos inusitados, e fiquei com aquela inveja sadia e feliz por eles que puderam vivenciar tal experiência, a construção de uma nova cidade.

Logo depois fui a Brasília em uma viagem semelhante, em um encontro de estudantes de arquitetura de todo Brasil. Era 1994, época de copa do mundo, Brasil tetracampeão. Lá estava eu em meio a outros estudantes na capital planejada de meu país, as aulas sobre arquitetura e urbanismo ajudaram a compreender a lgumas coisas, porém experimentar a sensação de estar no meio do Brasil foi para mim ma is entusia smaste.

Alguns anos se passaram quando voltei a Brasília, já como arquiteto, mas daí a passeio, e para a Chapada dos Veadeiros, um local mágico no interior desse país. Este fato vem ao caso por uma simples conversa. Estava eu conversando com um primo meu, quando perguntei onde iria dar aquela estrada que passava pela chapada, ele disse.... se você for sempre em frente chegará em Palmas, fica mais ou menos $700 \mathrm{~km}$. Logo me lembrei daquele meu amigo de faculdade e imaginei como estava longe de casa e como estava perto dessa cidade que para mim só existia nas aulas de urbanismo. Mesmo com uma coceira para seguir em frente, acabei retomando a Brasília e posteriomente a São Paulo.

Virei professor de arquitetura na Universidade Federal de Uberlândia, e para mim o cerrado já não era algo distante, mas parte do meu cotidiano. Nessa curta experiência por lá, dando aula de urbanismo e discutindo sobre cidades planejadas, novamente Palmas aparece na minha vida como um estudo de caso a 
ser compreendido. Na época tentei organizar uma visita com os alunos e outros professores para lá, mas a distância impediu que nosso encontro fosse antecipado.

Era 2003, Uberlândia tinha ficado para trás, e acabara de ingressar no doutorado. Em julho fiz algo que há muito não fazia, viajar com meu pai. Ele me convidou para ir a uma fazenda de um amigo no norte de Mato Grosso. Não fazia idéia para onde estava indo, mas aceitei. Encontrei com meu pai em Minas Gerais, e fomos de carro em direção a o centro do Brasil, novamente. Pela estrada passei por Goiânia, mas seguimos em frente pois ainda tínhamos muitos kilometros a percorrer até chegar ao nosso destino. Um pouco antes de escurecer vejo uma placa, bem vindo ao Tocantins. Era real, ele existia, e eu estava lá. Ainda me lembro de ligar para Liliane e contar onde estava, havia parado em Gurupi para pemoitar.

Partimos na outra manhã para a fazenda. Para lá chegar cruzamos o no Araguaia de balsa pela manhã, e para meu espanto vi centenas de pessoas acampadas nas suas margens. Estava em plena temporada de veraneio e as pessoas dessa região se mudam para os bancos de areia na época seca. Ainda lembro de meu pai falando, "esse é um outro Brasil, Glauco". Para mim era mesmo. Fomosà fazenda, passamosalguns dias lá e começamosa viagem de volta.

Cruzamos novamente o Araguaia, mas dessa vez paramos em um desses acampamentos para comer algo, nem lembro o que comi. Chegamos em Paraíso, na beira da BR 153, que cruza todo o Brasil de norte a sul. Como sabia que estava perto de Palmas, apenas 80 km, não pude deixar de pedir a meu pai para lá passar, pois precisava ver e conhecer aquela cidade planejada em meio ao cerrado brasileiro. Atrasamos um pouco a nossa volta, mas meu desejo foi atendido. Já era de noite e resolvemos que ińamos lá domir e seguir viagem na manhã seguinte. Paraíso está em uma cota mais alta, e de lá já pude ver um clarão que iluminava uma noite de julho de 2003, era Palmas. À medida que percomámos a estrada, o clarão sumia e voltava, dependendo da sinuosidade da pista, a té que uma hora ele acendeu de vez. Havíamos chegado ao outro lado do rio, a beira de um lago recém criado, e que só depois fui saber da sua história. Uma ponte me separava daquele momento, $8 \mathrm{~km}$, percoridos em linha reta, porém com o olhar se movimentando na busca de compreender aquele contexto. No fim da ponte, a chegada, e era bem no dia em que os jipeiros do Rally dos Sertões descobriam a cidade junto comigo. 
Não entendia direito onde estava, mas sabia do Palácio, que logo vi ao cruzar a ponte, e que a cidade tinha um eixo principal, mas que não sabia onde ficava e que tampouco se chamava Teotônio Segurado.

A descobrimos à noite e nos preparamos para viajar no próximo dia. Levantamos cedo e fomos conhecer novamente a cidade pela manhã antes de seguir viagem, algumas fotos do palácio, da Serra que então surgia com o amanhecer, e me preparei para ir embora em direção a São Paulo, guardando numa máquina fotográfica antiga, toda manual, restaurada e que levara na viagem para uma experimentação fotográfica, lembranças de um local que há muito queria conhecere que pensava comigo que dificilmente voltaria.

Não sei se foi o destino, mas voltei. Em uma reviravolta em minha vida resolvi prestar um concurso na Universidade Federal do Tocantins. Na época as dúvidas eram maiores que as certezas e para cada amigo que contava, recebia com um sinal de espanto perguntas como, "o que você está fazendo da sua vida?" Até hoje não sei. Lembro-me de relatar para minha orientadora para onde estava indo, em um a Imoço no Enepea de Belo Horizonte em 2004, contei-lhe que acabara de ser aprovado no concurso e que estava pensando em me mudar para Palmas. $O$ espanto não foi menor, mas a força dada me motivou a seguir esse caminho. $E$ segui.

Antes de ir para lá uma outra amiga me disse: sabe quem também mora em Palmas? O César, do Mackenzie. Era meu amigo que havia me perguntado na época da faculdade se eu ina naquela viagem. Dessa vez disse que sim. 


\section{Em busca da urbanidade}

O olhar atento do arquiteto pode suscitar diferentes questionamentos sobre a esfera urbana que o cerca e que o instiga. Vivenciar uma cidade planejada é presenciar um laboratório a céu aberto, onde estas questões podem ser levantadas através de uma simples caminhada, de uma simples mirada para a paisagem, ou de compreensões mais significativas de como conformar lugares. Os impactos de um projeto urbano são revelados não só pelos a mbientes físic os criados, sua estrutura visível, mas pela dinâmica social que se conforma, sua estrutura invisível, à medida que o espaço se consolida.

A pratica projetual do arquiteto e urbanista vem sendo posta à prova pelos gradativos, e novos posicionamentos quanto à verdadeira eficácia do modelo tecnicista de intervenção no espaço, de sua práxis como idealizador de lugares. Sua espacialização, esbarra em premissas cultura is que vem sendo estudadas por diferentes grupos de profissionais, mas principalmente pelas ciências humanas, como ponto de convergência para se construir um novo modelo.

È nesse cenário de entendimento que se propõem os estudos da Paisagem e Urbanidade: os limites do projeto urbano na conformação de lugares em Palmas.

A cidade de Palmas, a última cidade planejada brasileira do séc. XX, apresenta esse panorama, de conflitos gerados pelo traçado, pelo ordenamento de um plano determinista, e por uma condição cultural, política, econômica e social, que confronta diretamente o espaço concebido como ideal.

Os elementos que conferem ao espaço urbano qualidade, conformados nos limites entre o projeto e os condicionantes culturais que $o$ promovem, colocam em questionamento não a prática projetual, mas em que sentido esses são geradores e fomadores desta nova urbanidade para ascidades. 
O trabalho possui como tema principal as interfaces entre a arquitetura (projeto) e a sociedade (cultura), e em que medida a conformação da paisagem e dos espaços livres públicos definem esse diálogo.

Neste sentido, a hipótese central que permeia este trabalho é que os lugares conformados nos limites entre o projeto urbano e os processos sociais, são os princ ipais promotores dessa nova urbanidade.

As premissas deste trabalho se iniciaram no mestrado, quando no estudo das proposições urbanístic as sustentá veis, a ausência das discussões dos condicionantes cultura is na produção espacial, revelavam essa lacuna no disc urso a mbiental. Ta is proposições defendiam a tese de que a ecologia, promovida pela sustentabilidade urbana, é o principal caminho para alcançar e assim promover, um equilíbrio na relação entre homem e natureza, criando uma nova ética no desenvolvimento em todas as esferas da sociedade em prol de um bem comum, a manutenção dos recursos naturais para as gerações futuras.

Um novo papel da urbanidade, na época entendida como civilidade, iniciava os questionamentos sobre a prática de produção dos espaços através da dimensão cultural da sustentabilidade. A hipótese inicial a conceituava como uma tríade de qualidades que resultariam do equilíbrio entre: o urbano, ambiental e cultural, formando a base da sustentabilidade cultural. A investigação revelou seu caráter a djetivo, convergindo para uma percepção dos novos va lores qua lita tivos do espaço.

A pesquisa delimitou o espaço livre urbano e sua produção, como objeto central desta nova urbanidade. A abordagem dos temas que estruturam esse condicionante qualitativo das cidades, se caracteriza nos limites entre homem e espaço. Limites para esta pesquisa não se evidenciam como barreiras, como fronteiras, mas como possibilidades, potencialidadese como interfaces.

O objeto de estudo é a cidade de Palmas, Tocantins. O seu planejamento revela uma forte influência do tecnicismo e determinismo, definindo um projeto urbano que possibilita novamente, após Brasília, a 
discussão sobre os reflexos da produção do espaço sob uma ótica progressista. Porém, a cidade ideal encontrou variáveis rea is para o seu desenvolvimento, descaracterizando em parte o seu processo de conformação, evidenciando os condicionantes culturais, políticos e ambientais que definem uma nova condição para seu projeto.

O objetivo do trabalho é identificar os graus de urbanidade que se inserem em duas áreas distintas da cidade de Palmas, a Vila União e as quadras centrais, definidos por categorias substantivas e adjetivas no espaço, determinando em que circunstâncias projetuais e socia is os lugares são conformados.

\section{Metodologia}

O trabalho buscou no estudo de caso um forte aporte prático para os suportes teónico-conceituais que estruturam a pesquisa. A Vila União é um fragmento que contrapõem as diretrizes do projeto urbano, conferindo-Ihe uma outra condição qua lita tiva.

O principal viés teórico está na condição dialética do espaço, definido por Milton Santos, por objeto e ação. Em um primeiro ensaio, buscou-se o entendimento sobre a produção do espaço e da paisagem, e seus condicionantes cultura is de conformação. Para o trabalho foram elencados quatro eixos teóricos para explicitar o conceito proposto, dentre os quais: Espaço Público, Lugar, Cotidiano e Cultura Contemporânea. Estes definem como os processos sociais inscrevem as marcas das deteminadas sociedades, caracterizando as esferas públicas e privadas no espaço livre. Um segundo ensaio teórico refere-se ao projeto urbano, demonstrando as caractenísticas conceituais, sociais, morfológicas, e de sintaxe espacial, de paradigmas que tem como princípio o ordenamento urbano.

A pesquisa do objeto apresenta duas vertentes, a primeira, por informações de fontes secundárias, bibliográfica e órgãos govemamentais, estadual e municipal. A segunda são os levantamentos feitos em fonte 
primária. Para a demonstração da tese foram comparadas duas áreas distintas na cidade, a Vila União e as Arse 12, 13 e 14, escolhidas pelos diferentes processos de conformação espacial.

Foram feitas pesquisas in loco, observando-se os elementos que formata $m$ as categorias de análise elencadas para este trabalho; entrevistas com o autor do projeto da cidade, com o govemador que criou a Vila União, com o diretor de planejamento da cidade, e com os representantes dos moradores das quadras estudadas, a lém de levantamentos fotográficos e de sintaxe espacial.

Como referencial teórico, os principais autores utiliza dos foram: Marc Augé, Rosalyn Deutsche, Michael de Certeau, Hannah Arendt, Henri Lefebvre, Edward Casey, Nora Rabotnikof, Richard Sennett, Ruben Pesci, Ignasi de Solá-Morales, Mike Featherstone, Félix Guattari, Milton Santos, Maria Ângela Faggin Pereira Leite, Ana Fani Carlos, Bill Hillier, Maria Elaine Kolhsdorf, Frederico de Holanda, Otília Arantes, Antônio Carlos Robert Moraes, Tereza Caldeira, Heitor Frugoli J r. e Luc récia Ferrara.

\section{Estrutura do Trabalho}

A tese se divide em quatros capítulos principais. O primeiro discute os aspectos teórico-conceitua is dos eixos estruturantes deste trabalho: o espaço público, cotidiano, lugar e cultura. Essa discussão se baseia nos signific a dos contemporâneos do espaço livre como principal articulador da esfera pública, colocado aqui não só pelo seu aporte físico, mas pela dimensão política e abstrata que este abarca.

O segundo Capítulo refere-se aos pressupostos de urbanidade, como esses permearam a cultura urbana, na história e na atualidade. São apresentados os modelos projetua is das Unidades de Vizinhança e do Novo Urbanismo. As premissas das categorias de análise são enfatizadas sob a ótica colocada por Pesci e Holanda, definindo seus condicionantes projetua is e socia is de conformação. 
O terceiro capítulo caracteriza a cidade de Palmas e o estudo de caso, a Vila União, uma região dentro do plano que foi ocupada através de uma invasão promovida pelo poder público, como ação política contra o govemo anterior, e social, já que concedeu a posse da terra aos habitantes até então excluídos da área "legal" do plano. O texto permeia a história da cidade, a consolidação da desordem gerada pela gestão do espaço urbano, a formação dos espaços públicos e as três categorias de espaços verdes existentes.

O quarto capítulo descreve inicialmente o processo de conformação do espaço nas unidades de vizinhança, e como suas deteminações projetuais encontraram os limites de uma sociedade em formação. A segunda parte apresenta as categorias de análise da tese, elencadas a partir dos pressupostos de urbanidade do capítulo 02: múltipla centralidade, conectividade, movimento e permanência no espaço, relação entre espaço livre e construído, interface e espaço verde. Essa é uma análise crítica das duas regiões do plano, definindo assim os conceitos desta nova urbanidade. 


\section{A produção do e spaço}

As cidades se conformam e se constituem pelas diferentes práticas sociais que participam do processo de construção dos espaços, sejam eles construídos ou livres, ideais ou reais, projetados ou espontâneos, para em cada momento desta recente história, na relação tempo-espaço, inscrever as necessidades humanas dos diferentes grupos sociais no temitório geográfico proporcionado pela natureza primeira. A fomação da urbe indica cada etapa deste processo, subscrevendo histórias que conformam as paisagens, as identidades e os contextos culturais de cada espaço urbano.

Processos de transforma ção urbana sempre foram condicionados pela construção de sua memória e a essência de seus fatos coletivos, uma vez que a cidade (urbe), enquanto meio físico, concretiza-se não de modo unitário e coerente, mas sim de modo fragmentado e múltiplo em uma estrutura específica que, deteminada pelo espaço coletivo urbano, constitui-se no locus da comunidade. (ALVES, 2006)

\footnotetext{
“Na realidade, é o movimento histórico do processo de produção espacial que desvenda o fato de que o espaço geográfico não é nem etemo, nem inerte e imóvel, e tampouco natural, mas um produto concreto de relações socia is historic amente determinadas." (CARLOS, 1994, p 33)
}

Esse tema permeia estudos de pesquisadores de diferentes áreas, não se restringindo a um campo específico, criando uma interdisciplina ridade, pelo menos na teoria, na busca do entendimento dos fenômenos que produzem os diferentes espaços. A sua construção insere variáveis das sociedades em suas deteminadas épocas, sobre específicas paisagens e contextos biofísicos. Essa diversidade detemina que a aproximação de áreas que se relacionam com a questão urbana, como as ciências humanas, trazem uma importante interface no estudo sobre as formas de apropriação. 
A criação de uma nova ciência para o espaço, passa pelo entendimento das diferentes percepções destas áreas de estudo. Não pela visão holística e multid isc iplinar propagada como a ideal para a elaboração de estratégias que englobem vários conhecimentos, já que sempre existe a pré-disposição para a valorização de certas especificidades de maior afinidade do pesquisador, mas pela compreensão do estado da arte em que se coloca essa produção na contemporaneidade.

A produção do espaço é a ciência do uso, das necessidades, dos desejos e das diferentes possibilidades da apropriação humana sobre a natureza. Se para o geógrafo Milton Santos (1991, p 64), a produção do espaço é resultado da ação dos homens agindo sobre o próprio espaço, intermediados pelos objetos, natura is e artificia is, para a a rquiteta Kolhsdorf (1996, p 18), qualquer estruturação social não existe sem espaço. Ele é fruto das relações e da história do homem com o contexto que o cerca. As cidades enquanto produções sociais humanas, das trocas, dos fluxos e da constituição de sociedades, resultam ora se completando ao espaço geográfico, ora se opondo a ele, deteminando a sua sobrevivência.

\begin{abstract}
"A sociedade também produz o espaço e passa a ter dele uma determinada consciência. Refere-se ao fato de que os homens, ao produzirem seus bens materiais e se reproduzindo como espécie, produzem o espaço geográfico. Entretanto, dependendo do momento histórico o fazem de modo específico, diferenciado de acordo com o está gio de desenvolvimento das forças produtivas. 0 espaço passa a ser produzido em função do processo produtivo geral da sociedade." (CARLOS, 1994, p 22)
\end{abstract}

O espaço é o local dos conflitos e das contra dições, e muitas vezes da alienação das relações humanas sobre si mesmas e sobre a natureza primeira. Estes emergem na história a través da luta de classes e a través das suas múltiplas faces, entre o público e privado, entre o fragmento e o todo, entre a forma e a função, entre o abstrato e o concreto, e entre o ideal e o real. É a contra dição da própria existência do homem como ser social, onde os novos paradigmas de sua produção se alienam da condição natural e coletiva para a sua construção qualitativa. Assim como afima Lefebvre 
(2003), o espaço é a contradição entre as forças produtivas e as relações sociais de produção e de propriedade.

Este se constitui a tra vés das estruturas socia is, ec onômicas, polític as e culturais, das diferentes sociedades sobre a geografia de deteminadas paisagens. Em Palmas, objeto deste trabalho, a inserção de um novo espaço urbano no cerrado modific ou grande parte da condição natural existente. A cidade se apropriou da paisagem para a sua configuração, transformandoa, moldando-a a uma nova estrutura urbana e social.

“Cada tipo de paisagem é a reprodução de níveis diferentes de forças produtivas, materia is e imateriais, pois o conhecimento ta mbém faz parte do rol de forças produtivas." (SANTOS, 1991, p 64)

As estruturas desta pa isa gem, síntese formal e estética da apropria ção do suporte físico pela sociedade, alteram os condicionantes que dão a ela legibilidades como tal, modificadas pelas ativida des sócio-econômicas que definem e criam os espaços das práticas humanas, resultando em uma natureza segunda, do homem sobre a natureza, entre o sujeito e o objeto.

"Sensível como visualidade, a paisagem é uma apreensão surpreendente do real que, ao ganhar visibilidade, e só então, nos indica intervenções e formas de organização que melhor podem contribuir para concretizar as alterações deseja das pela sociedade, para dar um sentido às ações humanas, para permitir ver o espaço humano em perspectiva." (LETE, 2004, p 54)

O espaço é o produto, muitas vezes inacabado, da abstração promovida pelas ações antrópicas. Se para Lefebvre, este é fruto da percepção, da vivência e da concepção humana, o seu uso é a junção destes elementos, geralmente pautado na funcionalidade e mais valia que este deve apresentar e estruturar, o que normalmente acarreta na ruptura entre o espaço do homem e o da natureza.

Este estudo é a ciência da forma e da apropriação, sejam elas téc nicas, a rtísticas ou cultura is, formatando novos conhecimentos, na busca de cidades onde o ambiente urbano se perpetue como o lugar da representação e da prática social de deteminadas sociedades. O espaço 
deve ser considerado como um conjunto indissociável de que participam, de um lado, certo arranjo de objetos geográficos, objetos natura is e objetos sociais, e, de outro, a vida que preenche e os anima, ou seja, a sociedade em movimento. (SANTOS, 1991, p 26)

\begin{abstract}
“Espaço urbano e sociedade são duas faces da mesma moeda; ou seja, o espaço é um aspecto estrutural da cidade. Seu papel supera o conceito sociológico de suporte de atividades, pois não é um meio ńgido e neutro, mas capaz de oferecer possibilidades e restrições á realização de práticas. Sua natureza social implica que o espaço da cidade seja necessariamente histórico, no sentido de posicionado em marcos tempora is, geográficos e cultura is." (KOLHSDORF, 1996, p 21)
\end{abstract}

A atualidade das cidades reflete uma histónia de conflitos entre o processo e o produto da sua construção. Um dos desafios da contemporaneidade é sanar as múltiplas conseqüências da ruptura entre a natureza primeira e segunda, entre a esfera públic a a esfera privada, entre a fragmentação e a segregação que compõem hoje estas paisagens.

“A história humana é também uma inintemupta transformação da primeira em segunda natureza, num processo onde o homem vai alterando as paisagens da superfície da terra, imprimindo-lhes a sua marca." (MORAES, 1994, p 74)

As alienações dos que produzem o espaço, sem uma efetiva percepção dosfatores socia is e naturais, e sua conseqüente fragmentação, condiciona os novos paradigmas projetua is para uma reversão deste processo, na expectativa de criar uma alteração desta natureza segunda, integrando seus elementos com os valores antrópicos do cotidiano e da paisagem de uma cidade.

Para Milton Santos, a síntese do espaço se caracteriza pela sua configuração temitorial, pela dinâmica social e pelo conjunto de relações que definem uma sociedade, objeto e ação. A cidade é a fruto das somas, da pluralidade, da diversidade de situações que se interagem e se repulsam, configurando uma rede de espaços e de relações sociais, de estruturas visíveis e invisíveis, que transformam um fragmento em um todo e o todo em 
fragmento. Esta denomina ção refere-se às estruturas não físicas, visíveis a té certo ponto em nossa percepção.

\begin{abstract}
“No processo de apropriação da natureza, construção da paisagem e qualific ação do lugar, a atenção está deslocada para a ordem do fragmento, percebida através de situações básicas, monótonas e inalteráveis - em essência, a forma pela qual são perpetuados no lugar interesses de dominação - condenado todosa não percebero movimento real da sociedade, que é o movimento do espaço." (LEITE, 1992, p 76)
\end{abstract}

As estruturas sociais, que se conformam e se transformam no tempo, se caracterizam por significados e valores que são transmitidos no e pelo espaço. O contraponto entre o valor de troca e de uso é fundamental para sua produção e configuração, em um momento específico. Segundo Carlos (1996, p 65), o espaço e tempo são cada vez mais, no contexto das transfomações do processo produtivo, dominados pela troca. A cidade é historicamente local onde essas ocorrem, dos fluxos e da consolidação do ser natural em ser social.

\footnotetext{
“Pelo contrário, em oposição a esta tendência dominante e oficial, a verdade do espaço vincula o espaço, por um lado, a prática social e, por outro, a os conceitos elaborados e encadeados pela filosofia, ainda que superando-a como tal, precisamente graças a sua conexão com a prática ... Não há rea lida de sem uma concentração de energia, sem um foco ou um núcleo e, em conseqüência, sem um movimento dialético: focalização-dissipação, concentração fragmentação." (LEFEBVRE, 2003)
}

A rede de espaços caracteriza as tramas urbanas, que configuram as cidades e que permitem ao homem, condicioná-lo como um lugar, na busca de uma qualidade urbana e ambiental promovida principalmente pela sua diversidade de apropriações. Essa busca não se apresenta somente pelas possíveis e variáveis instâncias do projeto, mas pelas diferentes assimila ções dos condic iona ntes cultura is que estruturam a vida cotidiana de uma cidade. 
Essa diversidade possibilita a configuração de novas formas espacia is, onde a funcionalidade e formalismo do projeto são incorporados por práticas de ocupação e uso de deteminados grupos sociais.

Segundo Lefebvre, o papel e a função do espaço se deram através de seus símbolos, que na prática os produziu inicialmente diversificados pela dimensão do intuitus, transfoma do em habitus e depois em intelectus. Este, como símbolo da modemidade, abstraiu a importância das tramas sociais para a configuração de espaços "não gregários", da universalidade, e da monumentalidade que este deveria representar para a cidade e para a humanidade.

Seus símbolos são produzidos pelo cotidiano, pelos modos de produção e pelas relações sociais. Obsenvar como se comportam os movimentos no espaço urbano é essencial para o processo projetual e para sua conformação. O percebido (Intuitus), o vivido (habitus) e o concebido (intelectus) se tomam a tría de principal deste processo, que irá compor uma nova dialética entre homem e natureza.

As dimensões do percebido e do vivido, essencia is para delimitar as estruturas e funções das práticas sociais, são evidenciadas por métodos e teorias como o estruturalismo e a fenomenologia. A primeira, de acordo com Moraes, defende a estrutura como a categoria básica no entendimento de qualquer fenômeno social, enquanto a segunda, se refere à experiência vivida como base de todo conhecimento e observação das representações, como objeto da investigação.

A vertente culturalista da antropologia se baseia no pensamento estruturalista para o estudo do ser em grupo, das relações sociais, desconstruindo o sujeito enquanto indivíduo. O sujeito é social e ao mesmo tempo é indivíduo. Ele resulta da dimensão prática e histórica de como se produz a cultura, os ritose os signific ados de uma deteminada sociedade.

O concebido é a forma, a representa ção projetual do espaço a través dos desejos de deteminados indivíduos e sociedades. Através deles, percebe-se a legibilidade das estruturas visíveis que compõem o ambiente antrópico, a paisagem urbana, e as arquiteturas do edificado e do não- 
edificado. Ela carrega os símbolos construídos junto às cidades, e que podem ou não representar as práticas espaciais dos diferentes grupos sociais.

A crítica colocada neste trabalho não se refere somente à práxis do arquiteto, tampouco à cidade modema, mas dos limites do projeto como principal propulsor da qualidade urbana, dos limites com que o processo de criação e conformação do espaço se depara, e como os paradigmas culturais e ambientais podem ser incorporados na sua elaboração. Jane Jacobs já alertava sobre o fracasso dos modelos de planejamento, que destruíam os espaços da representação e das práticas socia is para a elaboração de projetos que se preocupavam ma is com as formas e funções como alegoria da vida cotidiana.

\footnotetext{
"Se, na escala da atuação, a paisagem, essa construção transtemporal, transversal, duradoura, não é produto unicamente da disposição de objetos valorizados pelo simples fato de terem sido desenhados por especialistas, de forma análoga, na escala da compreensão, o paisagismo é um modo de entendimento do espaço que transcende o projeto, embora dele se utilize como forma de conhecimento da rea lidade." (LEITE, 2004, p 55)
}

O ser humano busca o diferencial para satisfazer desejos, imprimindo no espaço as marcas que caracterizam os grupos sociais. O projeto urbano evidencia as diferenças através de formas e funções, porém, geralmente não se concentra na diversidade dos anseios dos grupos como pilar da sua prática. Para Lefebvre, o arquiteto ocupa uma posição desconfortável neste processo, pois como detentor da técnica aposta no repetitivo, e como artista aposta no diferencial para exaltar formas sensuais, curvas e outras inúmeras formas geométricas que o produzem.

A produção do espaço também engloba outros condicionantes que atualmente se aliam com a questão social, entre eles, a ecologia. Embora em alguns contextos ela se paute na questão das práticas participativas, através principalmente da inclusão no processo projetual de determinados grupos da sociedade, parte deste discurso ainda se refere à visão natura lista e à romântica da relação homem-natureza, proporcionando um conflito 
entre os desejos e as necessidades humanas no espaço. Na primeira visão, ela exclui a dimensão social dos problemas das ações antrópicas sobre o meio, enquanto a segunda prega um preservacionismo da natureza, colocando-a como um valor maior que o homem. (MORAES, 1994)

A priorização de uma em detrimento da outra, produz conhecimentos ora muito generalista, ora muito específicos sobre a questão ambiental. O urbano não se resume à ação antrópica sobre o meio e aos danos do homem a natureza. Busca-se uma ecologia que sustente a produção do espaço, proporcionando uma melhor interação entre o ambiente e o seu principal agente. Moraes (1994, p 30), enfatiza que o ambiental não se homogeneíza num só alvo de ação, antes se difunde como uma faceta inerente a todo ato de produzir espaço, enquanto que para Guattari (1990, p 33), a ecologia social deverá trabalhar na reconstrução das relações humanas em todosos níveis.

“A prática espacial não pode ser definida nem por um sistema existente (urbano ou ecológico) nem pela adaptação a um sistema. Ao contrá rio, o espaço se teatra liza, se dramatiza, graças às energias potencia is dos grupos diversos que desviam para o seu uso o espaço homogêneo." (LFFEBVRE, 2003)

Cabe ao projeto traduzir os limites desta nova ecologia, na incorporação dos valores culturais das relações sociais, e às ciências humanas, a incorporação dos valores ambienta is do discurso ecológico para a produção dos espaços urbanos. Se para Carlos (1996, p 15) o processo de produção do espaço é também um processo de reprodução da vida humana, ele deve refletir a cultura e os ritos dessas sociedades, que se apropriam do urbano para promoversuas relaçõese práticas.

Produzi-lo culturalmente compreende em evidenciar os limites entre a arte e a técnica na práxis do arquiteto. O vivido é a sua representação, criado a partir dos há bitos dos grupose dos atores socia is que correspondem às formas da apropriação humana. A dialética entre o espaço do homem, construído pela inserção das prátic as cotidianas, contra põem muita s vezes o espaço projetado, o do arquiteto, onde a técnica muitas vezes suprime as 
forças cultura is que deteminam a sua produção. Os ritos do cotidiano se apropriam dos espaços de formas variadas, dando-lhe significados diferentes do concebido. Assim como afirma Ferrara, o espaço é manipulado tecnicamente para adequar-se a uma estabilidade funcional que o submete a um código projetivo absoluto e imutável. (1998, p 26)

O antigo hábito de flanar por alamedas ou pelas praças das cidades, como o flanêur de Benjamin, não se encaixa em muitas novas culturas urbanas, mas que porsua vez, criam novos modos de interação. Estes geram acúmulos de funções e de signos de uma nova experiência coletiva, em parte fruto dos projetos urbanos que representam a atual realidade e necessidade da coletividade, e em parte pelas práticas sociais que imprimem suas marcas nos espaços de uma cidade.

A repetição com que se produzo espaço provoca uma alienação nos cidadãos sobre os elementos cultura is e ambienta is que os estruturam. Os paradigmas e tratados urbanísticos que se acumulam desde o movimento das Cidades-jardins, passando pelo movimento Modemo, até o Novo Urbanismo americano, espelharam alguns dos novos modelos de urbanização da contemporaneidade, e tentaram sem sucesso inserir elementos da prática social, coletivização e ecologia, no projeto, propondo profundas transformações na condição urbana em seus específicos momentos.

Não por acaso, muitos locais não projetados apresentam uma apropriação intensa, desafiando projetistas e intrigando os pesquisadores em observar como o espaço pode ser vivido sem a presença dos elementos comuns que denotam a este qualidade. Em muitos bairros, onde ruas são tomadas por pessoas de diferentes idades e por diferentes interesses, existe uma coletividade que exalta a vitalidade dos espaços de propriedade pública. Estes demonstram um sentido de pertencimento, não referida somente pela diferença de renda e pela imagem de ociosidade dos que utilizam as ruas, mas por sua representação no imaginário coletivo da população. 
“O espaço construído tem uma dupla caracterização: de um lado, demarca as formas de apropriação do espaço urbano; de outro, estas marcas representam o elemento comum de mútuo pertencer entre o espaço e a coletivida de que o dina miza." (FERRARA, 2001, p 15)

O espaço livre, caracterizado como todo espaço livre de edificação, é conformado por outros elementos físic os e socia is que o caracterizam como objeto de estudo da arquitetura paisagística. Esta categoria engloba diferentes esferas que serão abordadas posteriomente neste trabalho. Nestes, as deficiências e necessidades de um povo se revelam, se acomodam, e exaltam as forças do ser social, transmitindo os signos e valores de sua sociedade. Para Carlos (pg. 26), o espaço é produzido em função das exigências e nec essidades da sociedade. Mas em que limite este corresponde às necessidades destas? Qua is as interfaces entre o espaço e sociedade?

Uma nova cultura para o espaço urbano é necessária. A fuga para condomínios fechados é a fuga da diversidade das relações sociais, dos encontros com as diferenças e conflitos que este produz. Para Lefebvre (2003), as contradições da sociedade se revelam no espaço, no nível do espaço, engendrando as contradições do espaço. A tentativa de universalização do ser humano propagada pela utopia modemista, esbarra na redução de uma sociedade sem os conflitos que a caracterizam. Em Palmas, o conflito no e pelo espaço se revela na contraposição ao seu projeto, ao seu determinismo e a tentativa de ordenação das diferenças. É no espaço livre que estas ressaltam e alertam sobre a necessidade de repensar os limites do projeto para a conformação de lugares. No espaço se inscrevem, e ainda mais, se realizam as diferenças, da menor à extrema. (CARLOS, 1996, p 14)

A diversidade, ao mesmo tempo em que é gregária, também pode afastar o ser. Em Palmas, a delimitação de quadras para o uso residencial, sacramentou a divisão do espaço e a segregação que se estabeleceu com o crescimento da cidade. A tentativa de ordenamento organizou também a diferenciação social entre as quadras. 


\begin{abstract}
"As regras que organizam o espaço urbano são basicamente padrões de diferenciação social e de separação. Essas regras variam cultural e historic a mente, revelam os princípios que estruturam a vida pública e indicam como grupos sociais se inter-relacionam no espaço da cidade." (CALEIRA, 2000, p 211)
\end{abstract}

As práticas cultura is e espaciais devem se basear nas diferentes formas de apropriação que esta possibilita. Criar opções para vivenciar a cidade deve ser gerado pela interface de elementos, tanto do espaço livre como do construído, capazes de promover uma melhor qualidade aos ambientes.

\footnotetext{
“À paisagem caberia o papel de revelar a falsificação decorrente do descompasso entre as relações sociais, tal como estão estabelecidas, e a imagem que a representa, abrindo, através da percepção desse descompasso, caminho para mudanças desejadas." (LEITE, 1998, p 66)
}

Locais urbanos que historicamente exaltavam a coletividade e as trocas, a presentam agora novas formas de apropriação. Vivencia ro espaço não significa somente flanar por ele, mas interagir com seus elementos. $O$ espaço vivido, conceito adotado para representar locais com intensas interações sociais, materializa-se de forma a promover novas paisagens e novos lugares. Este é o locus das representações do cotidiano e da cultura de cada sociedade através dos hábitos de seus moradores. O ato de vivenciar se transmite pelos gestos mais banais de cada cidadão, seja por se sentar a uma sombra de árvore, por brincadeiras de crianças ou pela complexa rede de fluxosque se criam na trama de ruase edifícios.

Assim como afima Lefebvre, quantidade e qualidade são contradições nesse processo de produção. A qualidade não se restringe ao projeto, e tampouco à quantidade de espaços livres nas cidades. Seus diferentes níveis se interagem à medida que este é vivenciado pela população, que se apropria de diferentes formas e constrói a sua identidade. Esta contra dição é fruto de uma dialética entre a necessidade e a possibilidade de usos do espaço geográfico de uma cidade. Para Carlos (1994, p 33) o espaço geográfic o não é huma no porque o homem o habita, 
mas antes de tudo porque é produto, condição e meio de toda atividade humana.

\begin{abstract}
"A cidade oferece à sociedade um conjunto "ilimitado de escolhas" e de condições de vida. Como cada um satisfará sua necessidade, isto é, consumirá, o espaço estará vinculado ao lugar que ocupa no processo de produção geral da sociedade." (CARLOS, 1994, p 53)
\end{abstract}

Como produto das atividades humanas, o espaço apresenta a relação dia lética entre causa e efeito sobre o ser. Ao mesmo tempo em que é moldado pelo homem, causa sobre ele efeitos nem sempre esperados por aqueles que o deteminam: medo, insegurança, tranqüilidade, aconchego, perplexidade, solidão, visibilidade. Esses são alguns exemplos sentidos por cidadãos, sejam como indivíduos ou como grupos, experimentados como sensações proporcionadas pelo espaço, seja ele construído ou livre. Assim como afima Caldeira, se as experiências de separações impressas no meio urbano se tomarem hegemônicas em suas sociedades, elas se distanciarão da democracia.(2000, p 340)

A busca por uma nova urbanidade remete a uma associação dialética entre as estruturas que atuam no espaço, físicas e sociais. Estas, desde a sua concepção até a implementação, se deparam com as estruturas da socieda de e principa Imente com as a mbienta is existentes, e as que surgirão da sua transformação, abastecendo o ima ginário e os símbolos de uma sociedade, e permitindo, a cada indivíduo, inserir-se ou extrair-se do contexto urbano. Ele ao mesmo tempo é ator e é agente regulador das condições a mbienta is urba nas determina ntes para a sua qua lidade.

\footnotetext{
"la otra calle, la que no pisé nunca, es el centro secreto de las manzanas, los patios últimos, es lo que las fachadas ocultan, es mi enemigo, si lo tengo, es la persona a quien desagradan mis versos (a mí me desagradan también), es la modesta libreńa en que acaso entramos y que hemos olvidado, es esa racha de milonga silbada que reconocemos y que nos toca, es lo que se ha perdido y lo que será, es lo ulterior, lo ajeno, lo lateral, el bario que no es tuyo ni mío, o que ignoramos y queremos." (BORGES, cita do por ALVES, 2006) ${ }^{1}$
}

\footnotetext{
${ }^{1}$ A outra nua, a que nunca pisei, é o centro sec reto de outras quadras, dos últimos pátios, é o que as fachadas ocultam, é meu inimigo, se o tenho, e a pessoa a quem desagradam meus versos (a mim
} 
Cultura é o conjunto de práticas, técnicas, símbolos e valores que se deve transmitir às novas gerações para garantir a reprodução de um esta do de coexistência social (LEITE, 1998, p 65). Esta pode ser percebida através de seus hábitos, do seu cotidiano e de suas relações, ratificando a necessidade de encontrar os limites entre sociedade e espaço. As estruturas sociais legitimam o papel do espaço livre na construção da urbanidade. A complexidade humana é a essência de sua própria existência, e assim nos diferenciamos de outras espécies e de nós mesmos, individualizados pelas práticas que cada vez mais transfoma o ser huma no em ser independente e globalizado pelos novos sistemas de produção, alimentando novas teorias sobre a contemporaneidade e seus reflexos nestas relações.

A busca pela coletividade se toma, à medida que alguns centros urbanos intensificam diferentes processos de exclusão, um desafio aos urbanistas e planejadores, atados em parte pela prática tecnicista, e em parte pela ainda embrionária partic ipação dos a tores socia is. Esta, não deve ser somente um artifício político-estratégico para legitimar as ações do poder público com o aval da população.

A partic ipação popular não se legitima apenas nas decisões, mas pela vivência e pela inserção do indivíduo no cotidiano de uma cidade. Esta promove diferentes formas de apropriação do teritório, para realização de parte de suas atividades diárias, seja para o lazer, para o trabalho, para a contemplação do feio e do belo, ou simplesmente pela ociosidade que compõem a prática de muitos moradores, e que formam o balé das ruas (J ACOBS, 2000). A responsabilidade do conpo téc nico e dos interloc utores no processo participativo é, compreender essas estruturas invisíveis pa ra projetar o espaço de forma a condicionar os elementos edificados e a mbienta is às sociais que interagem sobre este, mas como também, gerar condições para que se institua em cada intervenção uma relação de identidade, pertencimento e principalmente visibilidade de cada grupo social.

\footnotetext{
também desagradam), é a modesta livraria que acaso entramos e temos esquecido, e essa música que reconhecemose que nos toca, é o que perdemos e o que será, é o exterior, o estranho, a lateral, o bairro que não é teu nem meu, o que ignoramose queremos.
} 
Regina Meyer, ao analisar a obra de Jane Jacobs, descreve que esta consegue subtrair do cotidiano, em seu livro Morte e Vida das Grandes Cidades, essas relações fundamenta is para criar um novo pensamento sobre urbanidade.

\footnotetext{
"O convívio entre as distintas funções urbanas - morar, trabalhar, passear, comprar, conviver, circular - e tantos outros que comparecem em profusão nos seus exemplos é a base da vitalidade urbana, matéria-prima da urbanida de." (MEYER, 2004)
}

As teorias de Jacobs se atualizam e se regeneram, à medida que as questões sobre como revitalizar a coletividade na vida cotidiana, ganham força nos discursos dos pensadores urbanos. O desgaste pelo qual o urbanismo passa, vendo-se em meio aos graves problemas das cidades, indica que as premissas ambientais, econômicas e políticas, não são suficientes para minimizar os impactos causados ao meio urbano. É necessário constituir uma nova consciência civil e cidadã nas diferentes classes de atores socia is que atuam na esfera urbana.

Locais onde há uma vivência urbana diferenciada, apresentam indicadores socia is muitas vezes traduzidos por números e índices, que impossibilitam uma compreensão da sua esfera cultural. Neste ponto, a sociologia, a filosofia e as artes, inserem-se nesta discussão da a rquitetura e urba nismo na contemporaneidade. Carlos Nelson a mpliou essa disc ussão ao perceberque existe uma ponte entre a rquitetura e antropologia.

As mudanças propostas pela ecologia trouxeram à discussão o papel dos recursos naturais dentro do planejamento urbano, e da preservação do ambiente natural. A ecologia, como foco central destas discussões, deve remeter a uma nova ética entre homem, cidade e natureza. A civilidade perdida deve ser incorporada a cotidiano dos habitantes de uma cidade, reforçando o papel da coletividade e da relação com o ambiente natural, através da cultura e da manutenção da diversidade no espaço. 


\section{A naturezada, na e para a cidade}

O termo natureza, costuma estar condicionado a algo intocado, preservado, onde a ação humana ainda não modificou a sua qualidade estética e o seu sistema. Isso não indica que nesses locais não ocorram transformações, causadas principalmente pela dinâmica do espaço natural e pelo sistema biótic o que o condiciona, fomatando a vida nestesloca is.

O ecossistema urbano apresenta uma dinâmica própria, e se relaciona com essa natureza primeira em diferentes âmbitos. Se a busca da urbanidade é pela qualidade das interações entre homem-espaço, as transfomações da natureza segunda apresentam um papel decisivo nesta conformação. Ta is modific ações condic ionam os elementos do urba no a um processo contínuo, que se conecta através da relação tempo e espaço. Por natureza entendemos a conexão sem fim das coisas, o interrompido produzir e negar de formas, a unidade fluente do acontecer que expressa na continuidade da existência temporal e espacial. (SIMMEL, 186, p 175)

A cidade não é natural, muito menos um ambiente que cresce como um organismo vivo, porém, seu crescimento e desenvolvimento interferem na dinâmica natural de seu ambiente. Esse contraponto desta relação se evidencia desde os estudos de Max, até as novas premissas da contemporaneidade do espaço urbano. Para Marx, a natureza tal como se transforma na história humana, é a natureza do homem.

O homem, sujeito, cria sobre a natureza, objeto, o espaço construído, através de ações que alteram o ambiente intocado, para uma área transformada, a natureza segunda, um produto humano. A sua síntese principal é a cidade, local das práticas sociais e do contraponto a ela própria. Essa soriginam a história de um lugar, de sua sociedade e do espaço transfomado. Para Lefebvre, a história social é a história da a propriação da natureza e de sua própria natureza. Masqual é a importância desta relação para a urbanidade? É preciso entender qual é a relação cultural entre natureza e sociedade, os signific adose valores que acarretam nas formas de dominação e ocupação, para assim imprimir suas marcas no espaço. 
"Já não há natureza, ao menos como se entendia antes dos modemos, a parte selva gem e virgem do "ali fora". Ali fora existe um conglomerado, a herança modema, um mundo no qual a natureza e artifíc io aparecem misturados e envoltos por um mundo vetorial e telemático - o jardim modemo. O mundo é um jardim construído pela modemidade, um jardim estupefaciente, desolador e sublime, c uja variedade e intrincamento tipicamente pitorescos estão feitos de contrastes nunca antes imaginados, uma paisagem na qual as chaminés de Auschwitz se misturam com o rastro catastrófico da Apolo XIII, e o fungo de Nagasaki com o das torres gêmeas, mas também onde os parques nacionais e as reservas da biosfera, convertidos num bem escasso, passaram a ser os santuá rios onde se desenvolvem as novas liturgias civis. Herdamos outra natureza, a soma da exploração modema e os restos devastados, uma segunda natureza que tem sua própria beleza e suas próprias leis, um mundo entrópico e de extrema fragilidade, onde inclusive a consciência do efeito borboleta parece a mpliar-se." (ABALOS, 2004)

Culturalmente, o homem se distanciou da natureza e começou a ser social, um fragmento dela, passando a dominá-la através de suas atividades, porém ainda dependente. Os novos hábitos distanciaram o homem do natural, e a sua acomodação em grupos o fez dependente também das atividades sociais. A função de civitas requer certo grau de civilidade que o homem natural já não seria capaz, adquirindo um outro papel dentro do processo produtivo dasações humanas.

A sua natureza, a urbe, é formada pela dominância das estruturas invisíveis que fazem parte das civilizações. Mesmo a cidade não sendo natural, ela surge atra vés de diversas va riáveis das ativida des huma nas, que tem como palco e cenário a natureza.

“A história humana é também uma inintemupta transformação da primeira em segunda natureza, num processo onde o homem vai alterando as paisagens da superfície da terra, imprimindo-lhes a sua marca." (MORAES, 1994, p 74)

A cidade é fruto da natureza humana, e seu distanciamento na produção dos meios urbanos, gerou uma ruptura de suas estruturas. A cidade é um sistema, regulado por suas necessidades e valores, é o locci de intersecção de processos socia is que tem origem em diversa sescala s socia is. (ALVES, 2006) 
Mas até que ponto a natureza é uma necessidade humana? Sua dependência como recurso é maior do que como espaço? Culturalmente o homem foi e ainda parece ser dependente desta. Segundo Lefebvre (1991, p 23) o homem cotidiano está ou parece estar ma is próximo da natureza do que o sujeito da reflexão e da cultura.

O crescimento das cidades na era industrial, não trouxe somente um grande contingente de pessoas e poluição ao meio urbano, mas outros aspectos cruciais para esta relação. Uma nova dinâmica se incorporava às antigas cidades, e uma nova cultura urbana nascia através desta contraposição.

Os danos causados a os recursos natura is no meio urbano são frutos da alienação à natureza, como estrutura e parte fundamental da constituição do urbano. Mesmo o elemento verde, que se incorpora de vez em propostas urbanísticas como a das Cidades Jardins e nos planos do movimento modemo, se destaca pela separação entre suas estruturas. Em poucos momentos da história ela ocorreu com uma visão diferenciada, integrada. Destacam-se os projetos e estudos de Frederick Law Olmsted, que a o criar parques e imaginar uma rede verde como um sistema de preservação dos recursos naturais, presentes principalmente em fundos de vale, objetivava incorporar as duas estruturas no ambiente urbano. Para Simmel, a natureza é a unidade sem fronteiras traçadas de um todo, porém a sua delimitação é essencial para a paisagem. (1986, p 175)

A necessidade de inúmeros parques, praças e espaços verdes em uma cidade entram nesta discussão, à medida que somente a razão da existência destes não é capaz de gerar urbanidade. Se quantidade não significa qualidade, função também não significa apropriação. Para Sennett, a função destrói a natureza de uma praça pública, que é a de mesclar pessoas e diversific a r atividades. (1988, p 26)

A natureza de uma praça em uma cidade remete a sua fomação, porém, os novos modos de apropriação do espaço tem tomado estes elementos resistentes às transformações da sociedade e da própria cidade. Projetar espaços livres ainda é uma grande dificuldade para quem trabalha 
com este tema, repetindo erros e baseando-se em velhos paradigmas para a criação de novos projetos.

\begin{abstract}
“Qualquer intervenção a mbiental, visando alterar a situação desses lugares de ninguém, exige, portanto, profundas transformações socioeconômicas e estruturais, que não são sequer mencionadas nesses projetos, deixando a desagradável impressão de que qualidade de vida é mais uma entre as muitas abstrações que caracterizam a impossibilidade contemporânea de ver o teritónio e seus luga res como tota lida de." (LEITE, 1997, p 106)
\end{abstract}

A precipitada, e muitas vezes equivocada, impressão de que muitas praças ou muitos espaços verdes conferem qualidade a deteminados loca is, esbarra nas suas formas de utilização. A visão contemporânea a que se refere Leite, pode ser traduzida pela compreensão dos aspectos cultura is que simbolizam uma sociedade, registrada pela ocupação de um deteminado território, e incorporadas a estes no seu processo de produção.

A qualidade de vida não se restringe somente à incorporação da natureza no cotidiano de uma sociedade. Estas relações são conferidas por uma ecologia social, referenciada porGuattari no item anterior, com valores e formas de apropriação distintas. Esta pode ser a base para a construção de uma nova relação entre homem-natureza no ambiente urbano.

Essa visão da ecologia, da real necessidade da natureza para o homem contemporâneo, e dos sistemas de espaços livres, é um desa fio para os pesquisadores do ambiente urbano. A sua busca se conforma pela tríade: urbano, ambiente e cultura, ou pela articulação entre os três registros ecológicos citadospor Guattari, denominados por ele de ecosofia.

\footnotetext{
"Apesar de estarem começando a tomar uma consciência parcial dos perigos mais evidentes que ameaçam o meio ambiente natural de nossas sociedades, elas geralmente se contentam em abordar o campo dos danos industria is e, ainda assim, unicamente numa perspectiva tecnológica, ao passo que só uma articulação éticopolítica - a que chamo ecosofia - entre os três registros ecológicos (o do meio ambiente, o das relações socia is e o da subjetividade humana) é o que poderia esclarecer convenientemente tais questões." (GUATTARI, 1990, p 08)
} 
A ciência do espaço deve incluir no seu processo de produção, a inclusão dos aspectos de percepção humana, de cognição e da participação de sociedade organizada para novos paradigmas do projeto. A percepção dos ritos e dos processos do cotidiano das sociedades, auxilia no seu entendimento do espaço, e das culturas que surgem nas cidades no atual momento da contempora neidade.

\section{Espaço público e urbanidade}

A urbanidade no espaço livre é um dos eixos estruturantes deste trabalho. Dentre muitos pontos que a caracterizam, um em especial se toma necessário, por colocar em evidência uma discussão que permeia tanto trabalhos aca dêmic os quanto trabalhos profissiona is, e que conceitualmente se destaca na definição da relação entre espaço, paisagem e sociedade.

A relação entre as esferas públicas e privadas do espaço, retoma alguns pontos levantados no item anterior, onde o papel da coletividade, das interfaces entre uso e apropriação, reafima a importância das interações socia is e dos processos de sua conforma ção.

O espaço público, caracterizado como o espaço de propriedade e apropriação pública, é amplamente exposto como principal limite entre sociedade e cidade. Este porém, pode se apresentar não propriamente como um elemento físico, delimitado, podendo haver outras conotações que conferem a sua publicidade. Marc Augé (1997, p 06) define o espaço público: no como un espacio delimitado y balizado en la superficie de la tierra, sino como ele espacio eventualmente metafórico donde se forma la opinión pública, se puede admitir paralelamente que el espacio privado en sentido literal - el de familia, por ejemplo, que se concreta en una casa o en un apartamento - sea un lugar en el que la opinión pública pueda expresarse, darlugaral debate. ${ }^{2}$

\footnotetext{
2 Não como um espaço delimitado e balizado na superfície da terra, senão como eventualmente metafóric o onde se forma a opinião pública, se pode admitir que o espaço privado em sentido literal -
} 
Co-habitar no espaço público significa se posicionar perante as diferenças geradas pelo coletivo, interagindo com os elementos físicos, polític os e socia is que o conformam. É justamente neste, que essas variáveis podem ter outro significado, de interfaces - ou debates, como alguns autores o caracterizam - entre os agentes que dão a ele legibilidade. Para Rabotnikof, o espaço público é sobretudo de ação, cuja visibilidade resulta de práticas sociais de produção e de reconhecimento.

\begin{abstract}
"The concept of public sphere makes it clear that public space cannot be reduced to empinically identifiable spaces. Public space can also be defined as set of institutions where citizens engage in debate; as the space where rights are declared, thereby limiting power, or as the space where social group identities and the identity of society a re both constituted and questioned." (DEUTSCHE, 1998, p $03)^{3}$
\end{abstract}

“Espacio público al espacio del debate público (que puede tomar formas diversas y no siempre empíricamente espaciales) y espacio de lo público a los espacios donde efectivamente, de forma empíica, se produce el cruce y el encuentro de unos y otros, eventua Imente, estos debaten. Distinguiremos igua Imente el espacio privado (el de los asuntos privados) y ele espacio de lo privado (en el sentido estrictamente espacial de la residencia privada)" (AUGE, 1997, p 06) ${ }^{4}$

O espaço privado, em contraposição a esse, é o espaço de propriedade e apropriação privada. As diferenças entre as duas esferas, assim como afima Sennett, realçam as manifestações ocorridas no ambiente geográfico de grande parte de nossas cidades. Mas qual o limite desta relação define ou não a urbanidade? A esfera pública potencializa a coletividade, induzindo a um modo diferenciado de relacionamento entre homem e espaço.

\footnotetext{
da família por exemplo, que se fixa em uma casa ou em um apartamento, seja um lugar em que a opinião pública possa expressar-se, dar lugar ao debate.

3 O conceito da esfera públic a deixa claro que o espaço público não pode ser reduzido a espaços identificáveis empiricamente. Espaço público pode também ser definido como local de instituições onde cidadãos engajam no debate; como o espaço onde os direitos são declarados, mesmo com poderes limitados; ou como o espaço dos grupos sociais identitários ou a identidade da sociedade são ambas constituíd as e questionadas.

${ }^{4}$ Espaço público a espaço do debate público (que pode tomar formas diversas e nem sempre empiricamente espaciais) e espaço do público aos espaços onde efetivamente, de forma empírica, se produz o cruzamento e o encontro de um e de outros, eventualmente, este debatem. Distinguiremos igualmente o espaço priva do (dos assuntos priva dos) e o espaço do priva do (no sentido estritamente espacial da residência privada).
} 


\begin{abstract}
"A distinção entre as esferas pública e privada, encarada do ponto de vista da privacidade e não do como político, equivale à diferença ente o que deve ser exibido e o que deve ser ocultado. Somente a era modema, em sua rebelião contra a sociedade, descobriu quão rica e variada pode ser a esfera do oculto nas condições da intimidade." (ARENDT, 1981, p 82)
\end{abstract}

Os limites das duas esferas se dão no e pelo espaço. Em Palmas, a herança modemista do traçado, produziu quadras residencia is com funções definidas, e com grande porcentagem de áreas livres públicas, dando uma ênfase a essa esfera na tentativa de promover a qualidade de seu a mbiente urbano. O projeto porém, interferiu nas formas de apropriação, se voltando para seu interior e formando guetos, enclaves, como se este fosse de cada morador da quadra e não da cidade. A segregação espacial e a força da esfera pública não se encontram em um limite físico, mas na fragmentação identitária no espaço.

“A idéia de espaço público emerge então como resposta a necessidade de presença cidadã frente à fragmentação identitária, e de reivindicação da pluralidade frente às velhas caracterizações unitárias." (RABO TNIKOF, 1995, p 01)

Para Crawford, os limites entre vida pública e privada se dão pela questão do consumo. Lugares conhecidamente marcados pelo uso público, são focos da crise contemporânea da democracia. Crawford cita Nancy Fraser, que no livro Rethinking the public sphere, critica Habemas, que vê o espaço público como o local da democracia, comparando-o com as antigas Cidades Estado. Na Grécia, mesmo a democracia era uma coisa um pouco contestada - ela pode assumir vários conceitos que permeia os limites entre público e privado. Não há um ambiente físico que represente completamente esta dimensão, sendo necessário uma multiplicidade de espaços para públicas expressões.

O espaço é mais do que sua estrutura, ele é o palco das ações humanas do cotidiano, onde atores e espectadores interagem de formas diferenciadas, utilizando sua estrutura visível para realizar as relações 
invisíveis. Para Lefebvre, é na vida cotidiana que se situa o núcleo racional, o centro real da práxis humana.

“O espaço público deve necessariamente reequilibrar as deformações e as novas exc lusões que o espaço de uso públic o mas de propriedade e gestão privada introduz na cidade." (GIANGREG ORIO, 2000, p 03)

O espaço público sobrevive em meio à diversidade e ao debate político, criando as interfaces necessárias entre as diferenças promovidas pela fragmentação espacial e as realidades culturais. A diversidade não é fruto a penas das a propriações, mas da capacidade de produzir significados coletivos. As premissa s cultura is são decisivas para que esse volte a ser local de convivência e civilidade, inserindo na ciência de sua produção a ênfase antropológica da práxis humana.

\footnotetext{
“The term public space is one component of a metoric of democracy that, some of its most widespread forms, is used to justify less than democratic polices: the creation of exclusionary urban spaces, state coercion and censorship, surveillance, economic privatization, the repression of differences and attacks on the rights of the most expendable members of society, on the rights of strangers and on the very idea of rights - on what Hannah Arendt called "the right to have right." (DEUTSC HE, 1998, p 02) ${ }^{5}$
}

As relações que se criaram na Vila União, apresentam uma estreita interface entre o público e o privado. A necessidade de se estabelecer no ambiente geográfico, proporcionou uma condição de conquista ao lote, do privado, apoiado pelo poder público, como foma de conter invasões nas áreas públicas da cidade. Do público ao privado, do privado ao público. A esfera comunitána fomada pelos anseios individuais a o lote, proporcionou uma força pela sua conquista.

\footnotetext{
5 O termo público é um componente de uma retórica de democracia que, algumas de forma muito evasivas, é utilizada para justificar menos que políticas democráticas: a criação do espaço urbano excludente, estado de coesão e controle, vigilância, privatização econômica, a repressão das diferenç as a ata ques aos direitos da maioria dos membros da socieda de, dos direitos dos estrangeiros e muitas idéias de direitos - no que Hannah Arendt chama de "direito de ter direito".
} 
“O temo público significa o próprio mundo, na medida em que é comum a todos nós e diferente do lugar que nos cabe dentro dele. Este mundo, contudo, não é idêntico à terra ou à natureza como espaço limitado para o movimento dos homens e condição geral da vida orgânica. Antes, tem a ver com o artefato humano, como o produto de mãos humanas, com os negócios rea lizados entre os que, juntos, habitam o mundo feito pelo homem. Conviver no mundo significa essencialmente ter um mundo de coisas interposto entre os que nele habitam em comum, como uma mesa se interpõe entre os que se assentam ao seu redor; pois, como todo intemediário, o mundo ao mesmo tempo separa e estabelece relação entre os homens." (ARENDT, 1981, p 62)

A sobreposição da esfera privada em relação à pública se faz notar em grandes centros urbanos, através da explícita segregação espacial provocada por novas formas de uso. Os muros, não somente limitam as duas esferas, como se faz no parcelamento urbano tradicional, mas inibe as a propriações públicas e as interfaces promovidas pelas diferenças. A c isão no espaço se revela pela ausência de trocas que deveria ser sua principal conformação. Caldeira reafima que é uma cidade de muros em que a qualidade do espaço público está mudando e de maneiras opostas à quilo que se poderia esperar de uma sociedade que foi capaz de consolidar uma democracia política. De fato, a segregação e o processo de ostensiva separação social cristalizado nas últimas décadas pode ser visto como uma reação à ampliação desse processo de democratização, uma vez que acabaram de forçar seu reconhecimento como cidadãos, com plenos direitos de se envolver na construção do futuro e da paisagem urbana. (2000, p 255)

A atenção aos limites e as exclusões nas quais produzem a segregação, pode nos auxiliar a desmistific ar a lgumas das ma is calcific adas idéias sobre o significado do adjetivo público para o termo espaço (DEUTSCHE, 1998, p 04). A qualidade do urbano se depara justamente com esses limites para se conformar como lugar. 


\title{
A cultura do Iugar
}

A cultura transmite identidade ao espaço público, incidindo diretamente na construção de lugares. Uma das questões do projeto urbano é conferir-lhe as múltiplas conotações e caracterizá-los como locus da a propriação coletiva. Criaridentidades para uma cidade planejada foi uma das premissas do plano de Palmas, tanto para seus projetistas como para seus gestores, conferindo a o espaço esse papel.

\begin{abstract}
"A velha noção pré-modema de cultura urbana - implicando certas cidades que estão sedimentadas na tradição, na história e na arte, abrigando construções e paisagens famosas que criam um forte sentimento de identidade local e coletiva - como a noção modemista, econômica e funcional da cidade "desculturada"- cujo espaço é denominado pelo layout em forma de grade e pela a rquitetura modemista dos arranha-céus - dão lugar à cidade dos limites de um "não-lugar", no qual as noções tra diciona is de cultura são desc ontextua liza das, simuladas, reduplic adas e continua mente revista se reestiliza das." (FEATHERSTONE, 1995, p 140)
\end{abstract}

Há um grande risco de muitos espaços urbanos tomarem-se locais desprovidos de memória, ou como afima Augé, para definir uma determinada categoria de espaço, de não-lugares.

Um lugar é representativo de seus ritos, tradições, identidades e imaginários. A polariza ção do discurso urbano em: ambiental, social, técnico e político; muitas vezes acaba por restringir o entendimento das dinâmicas cultura is que se sobressa em no espaço. É o conjunto de objetos cultura is que cria a paisagem e tra nsformam-na em lugar. (LEITE, 1992, p 70)

\footnotetext{
“Reservamos o termo Lugar antropológico àquela construção concreta e simbólica do espaço que não poderia dar conta, somente por ela, das vicissitudes e contra dições da vida social, mas à qual se referem todos aqueles a quem ela designa um lugar, por ma is humilde e modesto que seja." (AUGÉ, 1994, p 51)
}

A ênfase ambiental destacada em alguns projetos urbanos, principalmente pela crescente discussão dos problemas causados pelas ações humanas, se aliena, e em muitos casos não prioriza a dimensão 
cultural nas práticas espaciais, como parte integrante de um novo ecossistema, que se configura como o lugar contemporâneo.

\begin{abstract}
"Se um lugar pode se definir com identitário, relacional e histórico, um espaço que não pode se definir como identitánio, nem como relacional, nem com histórico definirá um não-lugar. A hipótese aqui defendida é a de que a supermodemidade é produtora de nãolugares, isto é, de espaços que não são em si lugares antropológicos e que, contrariamente á modemidade baudelainana, não integram os luga res antigos: estes, repertoriados, classificados e promovidos a "lugares de memória", ocupam aí um lugar circunscrito e específic o." (AUG É, 1994 p 73)
\end{abstract}

A efemeridade de alguns espaços nas cidades, criados e recriados sob óticas progressistas, muitas vezes é um indício da supemodemidade cita da por Augé. Ta is situa ções ocorrem pelo distancia mento entre o projeto, as manifestações, e os a contecimentos que se relacionam com os lugares, configurando a penas espaços alegóricos, de símbolos ic onográficos de uma cidade, porém que se perdem na escala gregária, e não apresentam a mesma força na criação de um sentido de pertencimento para estes.

\footnotetext{
“Lugar e cultura podem ser entendidos como uma adaptação criativa a mińade de experiências humanas individuais de transitoriedade e fragilidade, solidão e indiferença. O lugar suporta a necessidade humana de pertencer a um mundo significativo e razoavelmente estável, e o faz em diferentes níveis de consciência." (YI-FU TUAN, cita do por ALVES, 2006)
}

O lugar enquanto fenômeno qualitativo não pode ser reduzido a somente propriedades espaciais; qua ntitativa, abstrata, lógica, científica, e matemática. O lugar é também definido por substantivos, por qualidades das coisas e elementos, por valores simbólicos e históricos, é ambiental e fenomenologicamente se relaciona ao como humano, como espaço da existência, da vivência que promove interações e relações, cujo significado é valorizado pelo homem. Se um espaço é denominado por uma preposição, um lugar o é por substantivos e o seu caráter, por adjetivos. Lugar é espaço dotado de identidade. (ALVES, 2006) 
"Los lugares de las culturas históricas han sido, casi siempre, desafíos al tiempo, monumentos que acumulan la memoria combatiendo el olvido, evocaciones pemanentes de personas, gestos o instituciones fundacionales." (SO LA-MORALES, I. 1995, p 121)6

No livro The Fate of Place (1997), Edward Casey avalia a percepção de alguns autores, principalmente da filosofia, sobre a questão do lugar. Para ele, aprende-se muito sobre o seu significado e dos papéis que este assume em amplos os contextos, e de certo modo nos rendemos ao seu poder.

Bachelard oferece uma primeira face ao lugar, dentro e direto de uma imagem poética. Sua discussão aborda a imagem do ser terrestre na formação dos luga res verdadeiros e do pensa mento a ristotélico: para ser um lugar de imagens precisa ser receptivo e absorvitivo. O senso de lugar não é aquele que contém e perdura, mas como ilumina freqüente uma faísca de uma simplesimagem, como uma estrela cadente na escuridão da noite.

Espaço e lugar são entidades históricas, sujeitos para o tempo. O principal interesse de Foucault nesta relação, é a curiosa propriedade do ser em relação a todos os outros lugares, que questiona, neutraliza ou inverte os loca is onde acontecem suas relações para se designar, espelhar ou refletir. J acques Demida adverte sobre a falta de um endereçamento da arquitetura nesta relação: como construir converte espaços em lugares? Lugar é a condição de possibilidades para escrita - uma condição que não demanda o seu a to físico instantâneo.

A conformação de lugares indica uma forma relacional na qual o homem se sente pertencente ao espaço. Esta é uma conquista teritorial que traz consigo signific ados, memórias e heranças cultura is. Uma esquina de um bairo qualquer pode ser um ponto de encontro de jovens e ter um amplo significado para este grupo, independente das condições projetua is existentes. É no espaço público que esta condição da existência do homem urba no se evidencia, onde as a tivida des socia is são expressas e impressas na

\footnotetext{
6 Os lugares das outras culturas têm sido, quase sempre, desafios ao tempo, monumentos que acumulam a memória combatendo o esquecimento, evocações permanentes de pessoas, gestos ou instituições inic ia is.
} 
cidade. Assim com afima Hannah Arendt, os homens são seres condicionados: tudo aquilo com o qual eles entram em contato toma-se imediatamente uma condição de sua existência. (1981, p 17)

“A natureza simultaneamente física e social do espaço a rquitetônico e urbanístico faz com que se o caracterize como um lugar, isto é, porção temitorial onde se desenvolvem práticas sociais com uma gama de possibilidades muito diversificadas, onde se incluem as contemplativas, de fruição estética ou incursões cognitivas." (KOHLSDORF, 1996, p 20)

O sentido de pertencimento se liga aos lugares habitados, marcados na história pela presença humana, acarretando na acumulação cultural dos espaços. Segundo Carlos (1996, p 83), a cidade não conta o seu passado, mas o contém como nas linhas das mãos.

O processo para a confomação da urbanidade, passa pela reconstituição no espaço dos fenômenos dos grupos urbanos atra vés de sua cultura. Segundo Guattari, (1990, p 16) a questão será literalmente em reconstituir o conjunto das modalidades do ser-em-grupo.

Para Heidegger o lugar é intrigante, valioso, realmente indispensável, já não só algo para ser lisonjeado como tal. Está na hora de voltar a pensar nestas questões do ser. O respeito do homem com os lugares e, a través dos lugares, descansa o habitar. (HEIDEG GER, 1994, p 139)

\footnotetext{
"A incapacidade de entender ou de reproduzir um contexto é, portanto, uma ruptura no processo cultural de construção da paisagem, que faz desaparecer a atenção ao circundante, ponto de partida para o registro de sensações que, posteriomente, serão interpretadas, traduzidas e deslocadas, criando novos lugares e assegurando a transmissão, às futuras gerações, de prátic ase valores socia is." (LEITE, 1998, p 68)
}

Assim como afima Leite, a gerações futuras herdam as formas de produção social, configurando as paisagens. Os valores de uma sociedade, traduzem-se em espaços que se identificam e se perpetuam no imaginário coletivo. Os espaços públicos trazem esses traços, criando as identidades nec essárias para a consolidação da esfera pública da vida. 


\begin{abstract}
"Trata-se de restabelecero marco do espaço público da sociedade contemporânea, o espaço por excelência da polis. A paisagem não é mais esse bonito fundo sobre o qual se destacam belos objetos escultóricos chamados de arquitetura, mas o lugar no qual pode instalar-se uma nova relação entre os não-humanos e os humanos: um fórum cósmico onde devemos reescrever toda a herança recebida; a democracia estendida às coisas, em novo pacto." (ABALOS, 2004)
\end{abstract}

O lugar como foco de significações coletivas reúne tudo o que o estruturalismo tentou demolir. a história, a continuidade, a memória, a tradição, a consciência (mesmo coletiva) enquanto fonte irredutível de sentido - enfim tudo aquilo que faria o sujeito (o inimigo mortal daquele ideário) sentir-se em casa, reconhecer-se nalgum monumento, na prática acumula da de a lgum modo de vida. (ARANTES, 1993, p 128)

A fragmentação espacial e social é fruto de um modelo de projeto enraizado em questões funcionalistas e tecnicistas, marcado através das tramas urbanas, onde o diálogo entre esfera pública e privada é inscrita de modo não condicionado à sua interação, mas segregadas no contexto urbano. O limite entre as duas esferas não está somente no espaço, mas na sua capacidade de se conformar como lugar. Esta é uma experiência pessoal, na busca de um entendimento da complexidade dosfragmentos, é uma leitura de todo processo de produção social que ocorre nascidades.

\footnotetext{
“No processo de apropriação da natureza, construção da paisagem e qualific ação do lugar, a atenção está deslocada para a ordem do fragmento, percebida através de situações básicas, monótonas e inalteráveis - em essência, a forma pela qual são perpetuados no lugar interesses de dominação - condenando todos a não perceber o movimento real da sociedade, que é o movimento do espaço." (LEITE, 1992, p76)
}

O uso e a interpretação do espaço coletivo de Palmas geram identidades para a cidade, não só pela integração à paisagem local, mas pelas formas de uso do espaço no cotidiano de cada morador, que utiliza as áreas públicas e constrói as múltiplas facetas desta cidade, possibilitando a diversidade. O uso decodifica o projeto confenindo identidade ao lugar. A 
identidade é, simultaneamente, uma questão de projeto e uso, de código e interpretação.(1998, p 69)

O lugar cria e transmite o sentimento de pertencimento, essencial para o melhor uso e apropriação do espaço público. A identidade de um lugar marca os costumes e ritos de uma sociedade, apresentando os valores cultura is detemina ntes para a transmissão para as futuras gerações.

\section{A ordem da desordem - os usosdocotidiano}

O planejamento urbano é a principal ferramenta que visa, entre outros objetivos, ordenar o crescimento e desenvolvimento das cidades. Isto é amplamente difundido no meio profissional e acadêmico, onde a cada instante, novos modelos são concebid os para serem a plic a dos nos diferentes problemas que o meio urbano acarreta.

Mais participativo e preocupado com seus resultados, este inverte parte de seu caráter tecnicista, onde o processo feito por agentes técnicos ignorava todo o conhecimento empíric o da população envolvida. Ele agora se pauta na interação dos diferentes atores sociais, para o devido sucesso de cada etapa do plano.

Este não se dá exclusivamente através do concebido, mas também pelo vivido e pelo percebido no processo de sua produção. A participação dos diferentes a tores abastece o planejamento de conhecimentos empíric os de diferentes grupos sociais, de fatos e hábitos do cotidiano, e de fatores cultura is.

A discussão sobre o papel do plano na produção do espaço remete a algumas observações: Qual o seu limite na construção de lugares? O ordenamento é a principal ferramenta para promover sua qualidade? Observando o plano da cidade de Palmas, e verificando algumas contraposições ao ordenamento original, uma outra observação é suscitada: há uma ordem na desordem do espaço urbano que acarreta em sua qualidade? O que importa para esse trabalho, não é demonstrar que o 
projeto urbano não apresenta um papel decisivo na conformação dos espaços, mas apresentar que a sua contraposição denota os limites em que este é capaz de promovera urbanidade.

"Aunque el acontecimiento es siempre algo que sucede en el desorden global de sentido, este momento feliz, as veces casual as veces resultado de una inteligente voluntad, constituye un instante emergente en un fluir constante, un acorde amónico, polifónico en una situación de permanente transición." (SOLÁ-MORALES, 1995, p $122)^{7}$

Dentre estas questões ressalta-se: a segregação ocasionada pela esfera privada em detrimento da pública, a rigidez do zoneamento e do projeto como forma de ordenar a vida nas cidades, a deterioração do espaço a través da incipiente interpretação dos pressupostos cultura is, o que acarreta na maioria das vezes na falta de sociabilidade necessária para a urbe, e a falta de entendimento das dinâmicas, ou movimentos, no espaço, de forma a garantir a sua visibilidade. Assim como afima Leite, Sem a cultura, a ocupação é meramente utilitária, pois somente a cultura é capaz de reviver os signos da identidade social, representando-os pelo trabalho coletivo. ( $p$ 69)

As cidades planejadas são cuidadosamente projetadas para prover diversidade espacial, porém, a abstração da ordenação urbana é uma grande dificuldade enquanto tônica da sua construção, onde a funcionalidade e a expressão do desenho, demarcam o conflito entre o concebido e o vivido.

\begin{abstract}
"A histórica multiplicidade de funções foi sendo aos poucos enfraquecida, com a crescente dispersão da vida urbana em diversos fragmentos, visando entre outras coisas disciplinar o uso dos espaços centrais, circunsc revendo grandes grupos a determinados loc a is confina dos." (FRUG OU, 1995, p 15)
\end{abstract}

\footnotetext{
7 Ainda que o acontecimento é sempre algo que sucede na desordem global do sentido, este momento feliz, às vezes casual às vezes vontade de uma vontade inteligente, constitui um instante emergente no fluir constante, um acorde harmônico, polifônico em uma situação de permanente transição.
} 
Há uma ordem social que contrapõem a funcionalidade e o determinismo propostos pelos planos, caracterizados pela espontaneidade, e que gera uma outra qualidade urbana, ou urba nidade. A infomalidade e a desordem nem sempre promovem o caos. A produção dos espaços e a formação de uma paisagem, remetem a fatores que transcendem a sua uniformização pelas diretrizes preconizadas pelo plano. É a síntese entre a esfera pública e a privada.

A antítese desta relação é responsável pela ruptura entre o vivido e o concebido, e da perda de qualidade de vida urbana e da civilidade - a incivilidade aliena o cidadão. A percepção da cidade se fragmenta assim como é fragmentado um bairro, uma rua, uma praça ou um parque. A separação das funções esquiva o habitante da totalidade, isola ndo-o.

Um dos principais itens citados por Jacobs para dar vida ao espaço público, é trazer uma diversidade de usos que dêem a este, a vitalidade necessária para transformar uma vizinhança. Outros usos acerca de uma pequena praça podem gerar variadas formas de apropriação, e assim manter a segurança em vários momentos do dia, e não apenas em alguns peńodos. Para Jacobs, nascidades a animação e a variedade atraem ma is a nimação; a apatia e a monotonia repelem a vida. (2000, p 108)

“Cidadania está para a cidade assim como urbanidade está para o urbano: possuem radicais comuns que, no encontro de seus significados, nos proporcionam os conceitos de dignidade e civilidade." (KOHLSDORF, 1996, p 15)

A coletividade é gerada por uma ordem social que delimita - porém não limita - o papel do homem no espaço público. Essa ordem possibilita uma diversidade de situa ções urba na s que exalta m o viver nas cidades, que se constrói e se apropria dos imaginários e da formação de lugares. A ordem sócio-cultural dos espaços é transmitida pelas formas espontâneas, pelas interfaces entre o predestinado com o acaso, e pela organização econômica que orienta estas relações. 
Se o lugar é a "alma", o espaço público é o "coração" da cidade. É onde se sente o pulsar, os ritmos, os excessos e a vitalidade do ambiente urbano. É também o local das transgressões, das manifestações, mas também do potencial de transformação dos contextos urbanos, e é a través dele que as relações humanas denotam novos valores, e se referenciam como práticas.

Compreender as origens deste "caos urbano" é verificar em que pontos o projeto urbano encontra seus limites, na busca das va rá veis que os produzem. Há situações onde este "caos" é formado pela essência da apropriação humana, da história e da memória, traduzida pelas necessidades e desejos humanos. O seu estudo remete a uma reflexão do momento da ruptura entre o privado e o público, e como a relação cultura e natureza apresentam reflexos diretos nas práticas pós-modemas do cotidiano.

Alguns alamistas se referem à "morte" do espaço público como uma coisa eminente e irreversível. Exageros a parte, este fato foi visto como um sinal de alerta para os planejadores e pensadores das cidades. Estímulos ao uso de locais públic os não faltam. Espaços livres são cria dos como incentivos em utilizar não só áreas públicas, mas contemplar uma natureza criada e transformada para oferecerqualidade de vida.

Inserir as questões ambientais no projeto, é uma das metas do desenvolvimento sustentável, porém, como fazer com que esta premissa projetual beneficie não só ambientalmente, mas culturalmente o cotidiano do ser humano, é o foco de discussão de pesquisadores que tentam fechar uma equação ainda em aberto.

O discurso do planejamento urbano coloca o espaço público como a liado às prátic as cultura is, porém, a natureza destes, nem sempre caminha para a melhoria da cidadania e da cotidianidade da população. É o conflito dos valores e direitos dos elementos que constituem um ecossistema urbano. Assim como afima Sennett, a noção modema de direitos humanos provém de uma oposição entre natureza e cultura. (1988, p 117). 
A esfera pública legitima o espaço conferindo-lhe valores, que nem mesmo o projeto pode almejar. A sua visibilidade é fundamental para a criação da cidadania, pois é através dela, que a qualidade do espaço urbano estará condicionada. O contrário, pode acarretar no que Leite afima, a ausência de vida pública é, assim, responsável não somente pela ausência de cidadania, mas também pela negação, a todos, do direito à vida com qualidade. (LEITE, 1997, p107)

"A linha divisória entre vida privada e vida pública constituía essencialmente um terreno onde as exigências de civilidade encamadas pelo comportamento público, cosmopolita - eram confronta das com as exigências da natureza." (SENNET, 1988, p 33)

Combater a sobreposição da individualidade sobre a coletividade não a esfera privada, pois ela é complementar a esfera pública na contemporaneidade - requer mudanças nas práticas projetuais e no processo de conformação do espaço. A individualidade renega a vida coletiva e a diversidade urbana, fazendo com que o indivíduo se isole dos acontecimentos do cotidiano. A idéia universal de cidade como bem público, lugar do convívio, do conflito e do congraçamento entre pessoas, vem sendo enfatizada por uma outra idéia de urbanidade. (ALVES, 2006)

A relação entre indivíduos passa a ser uma experiência cidadã que poderá ocasionar o respeito ao meio ambiente natural e urbano. O esboço de uma vida comunitária passa necessariamente pela ruptura dos paradigmas tecnicistas do planejamento que, embora criticado pelos pensadores urbanos, ainda permanece nos seus modelos de produção.

"Conviver no mundo significa essencialmente ter um mundo de coisas interposto entre os que nele habitam em comum, como uma mesa se interpõe entre os que se assentam ao seu redor; pois, como todo intermediário, o mundo ao mesmo tempo separa e estabelece relação entre os homens." (ARENDT, 1981, p 62)

Pensar em uma nova cotidianidade é intervir no limite entre o homem e o lugar. As catástrofes urbanísticas, não somente modemistas, mas contemporâneas, que pré-deteminam uma vivência cotidiana, ou se 
transformaram pela força da apropriação humana ou se esvaíram no tempo pela falta de atratividade e simbologia do lugar.

O cotidiano é o contato do dia a dia, tão ou mais dinâmico e complexo que o ecossistema natural no qual sempre nos salientamos quando resolvemostratar da natureza. A ecologia humana indica que uma rede de processos sociais são ferramentas essenciais no tratamento do espaço. Assim como afima Lefebvre em A Vida Cotidiana no Mundo Modemo (1991, p 08), a história de um dia engloba a do mundo e a da sociedade.

A banalização das ações e reações que ocorrem na vida, deixou uma lacuna na forma de se pensaro projeto urbano. O papel do espaço público, de unir pessoas, e principalmente da espontaneidade, foi absorvido pelas práticas projetuais que distribuíam a funcionalidade a cada setor, propiciando novas contradições no espaço. Assim com afima Carlos, o contato cotidiano evidencia modos de vida, de problemas e perspectivas comuns (1996, p 73). Este não é somente a posição da sociedade quanto às práticas diárias, mas a forma como a sociedade percebe, interage e se apropria do espaço urbano, dando-lhe sentido. É onde são tecidos os modos de ser de cada indivíduo, o conjunto de afetos e as diferentes modalidades do vivido, os a contecimentos.

\begin{abstract}
"Pero el acontecimiento es también un punto de encuentro, una conjunción en la que líneas de recomido ilimita do se entrecruzan con otras creando puntos nodales de unas intensidad emergente. Finalmente el acontec imiento es una aprehensión, el resulta do de la acción de un sujeto que en el fluir caótico de los acontecimientos atrapa los que más le atraen o más le conmueven para retenerlos. Es una acción subjetiva. Produce un momento de gozo y de una frágil plenitud." (SOLÀ-MORALES, 1995, p 122)8
\end{abstract}

Em Palmas, a profusão de culturas, toma o cotidiano uma combinação de diferentes práticas sobre o espaço público e que

\footnotetext{
8 Mas o acontecimento é ta mbém um ponto de encontro, uma conjunção na que linhas do recomido ilimitado se entrecruzam com outras criando pontos nodais de umas intensidades emergentes. Fina Imente o acontec imento é uma a preensão, o resultado da ação de um sujeito que no fluir caótico dos acontecimentos apanha os que mas the atraem ou que mais the comovem para retê-los. É uma ação subjetiva. Produz um momento de gozo e de uma frá gil plenitude.
} 
conformam novas paisagens. O retomo dessas atividades à rua requer ao mesmo tempo um grande esforço por parte dos planejadores urbanos e um pequeno esforço por aqueles que têm na rua o local do encontro, da diversão, do trabalho e da contemplação. Esta é o grande símbolo urbano que deve ser materializa do como palco de suas principa is a tividades.

\footnotetext{
“Tratando-se do cotidiano, trata-se, portanto, de caracterizar a sociedade em que vivemos, que gera a cotidianidade (e a modemidade). Trata-se de defini-la, de definir suas transfomações e suas perspectivas, retendo, entre os fatos aparentemente insignific antes, alguma coisa de essencial, e ordenando dos fatos." (LEFEBVRE, 1991, p 35)
}

Enaltecer a cotidianidade significa evidenciar as práticas socia is no processo de produção do espaço, e introduzir fatos fundamentais que ocorrem na sociedade, não de forma figurada e ilustrativa, mas ordenada e partic ipativa, revelando a todos aqueles que produzem a cidade, a vivência de seus habitantes. Assim como afima Crawford, esses são espaços que, caracterizados por distintas situações discursivas, podem tomar forma e serem redefinidos por atividades transitónias de públicos múltiplos que as acomodam.

Respeitar o a mbiente atra vés das práticas cotid ia nas deve resultar em um maior envolvimento da sociedade, tanto no processo decisório, como também na produção, e a propriação dos espaços, indispensáveis para a conformação da paisagem nas cidades. Crawford caracteriza, Espaço do todo dia, aquele que se conecta com diversas atividades - invisível no discurso profissional da cidade. A alienação urbana às essas atividades, é determinada principalmente por dois fatores: a individualização do homem e as mudanças na esfera pública em relação a sua natureza, que sofre um acelerado processo de mutação. Este é fruto de uma nova cultura contemporânea para o espaço público. 


\section{A cultura e o I ugr na contemporaneidade}

O enfraquecimento da esfera pública é fruto da formação de uma nova cultura urbana, secular e capitalista. A pós-modemidade é o resultado da união entre os novos aspectos que permeiam a sociedade contemporânea, na qual, a cultura da esfera privada toma uma proporção assustadora, e interfere na cultura da esfera pública. Para Featherstone, o conceito de pós-modemismo pretende realçar as mudanças nas experiências e práticas cultura is cotidianas de grupos cultura is ma is a mplos (1995, p 29).

A contemporaneidade nos apresenta à uma cultura urbana apoiada em valores cada vez ma is individua liza dos, transformando o espaço urba no em locais meramente de trânsito, de consumo e de controle. A idéia de espaço público como local do debate, da democracia, pode ser contestada com as práticas de construção do espaço na contemporaneidade. Uma questão colocada por Crawford, está em como reverter esse consumo do espaço, se a cidade esta virando um grande mercado. Outra é como definir na atualidade o conceito de espaço público. Para Deutsche, o espaço público é em si uma questão.

Os símbolos da pós-modemidade insc revem suas marcas. Nas grandes cidades surgem novos processos urbanos como a requalificação, renovação, reciclagem e preservação. Em paralelo a estas questões, a figura do ser social se constitui a través de formas intuitivas, determinando seu novo papel na constituição da urbanidade, e de novasposturascidadãs.

\footnotetext{
“Com relação à cidade ocidental contemporânea, está-se argumentando que as tendências pós-modemas e pósmodemizantes podem ser observadas nos novos espaços urbanos, assinalando uma estetização maior da trama urbana e das vidas diárias das pessoas, o desenvolvimento de novos redutos de consumo e lazer (tais como shopping centers, parques temáticos, museus) e a volta das populações da nova classe média às áreas centrais restauradas. Estes impulsos pós-modemos sugerem identificações menos fortes com o local de moradia e um habitus ou conjunto de disposições e classificações estruturadoras dos enc ontros socia is - menos fixo e menos rígido." (FEATHERSTONE, 1995, p 152)
} 
A crítica à modemidade, a o espaço idealizado para o homem ideal e universal, adquire mais força à medida que os desejos da sociedade são confrontados com estas novas realidades citadas por Featherstone. As práticas espaciais devem conduzir a uma nova postura democrática de construção do espaço. Assim como afima Moraes, a questão ambiental está imbricada com a questão democrática, sustentada por uma nova cultura participativa, que denota a força desta postura nas práticas do cotidiano no ambiente, seja ele natural ou urbano.

O Pós-modemismo é, segundo Jameson, um conceito de periodização cuja principal função é correlacionar à emergência de novos traços forma is na vida cultural, com a emergência de um novo tipo de vida social e de uma nova ordem econômica - sociedade do consumo. Transfomação da realidade em imagens, fra gmentação do tempo em presentes perpétuos.

Os grandes marcos da história das cidades hoje são frutos do consumo, da museificação: os objetos perdem o seu valor cultural inicial para se transfomarem em imagens - desse processo a arquitetura não escapou. Para Solá-Morales, o projeto modemo pode ser grifado como ilusão: de esperança e de engano - a arte, a ciência, a prática social e a política, podem se construir com base em uma racionalidade global - essa crise resulta na contemporaneidade. O lugar contemporâneo há de ser o encontro de caminhos que o a rquiteto deve apreender. (1995, p 124)

Rabotnikof crê que há uma teoria sobre o espaço público, mesmo com um desconcerto de categorias herdadas dela, o que explica o ressurgimento e a sobrecarga da idéia que este deve suportar no presente. Para Arendt a emergência histórica do consumo esteve relacionada à falta de investimento sócio-cultural na ação política, ao aumento da produtividade industrial, e na conversão imaginária do trabalho à atividade do labor. A falsa felicidade promovida pelo consumo resulta em falsas espacialidades. A legitimidade do espaço não está condicionada a sua imagética, masa sua vivência e apropriação. 
"Lo que se defiende en estás líneas es el valor de los lugares producidos por el encuentro de energías actuales, gracias a la fuerza de dispositivos proyectuales capaces de provocar la extensión de sus ondulaciones y la intensidad del choque que su presencia produce." (SO LÁ-MORALES, 1995, p 124) ${ }^{9}$

Se para Sennett a geografia pública de uma cidade é civilidade instituciona liza da, e se esta é como coloca, tratar outros a inda como se eles fossem estranhos e fojar um vínculo social sobre aquela distância, o conceito de espaço público na contemporaneidade esbarra nos limites entre o ser social e o espaço urbano.

“Es la substitución del empinismo psicológico, fundamenta lmente de la psicología de la percepción gestáltica por la fenomenología husserliana la que propondrá la substitución de la noción de espacio porla de lugar." (SOLÁ-MORALES, 1995, p 114)10

O discurso da pós-modemidade rompe com alguns dos pressupostos preconizados pelo movimento modemo, influenciando uma ruptura formal, estética e perceptiva para a consolidação de uma nova cultura do espaço. Uma forma está no modo de abordagem e de prionização dos detalhes que refletiam velhos desejos de uma hierarquia hamonizada de controle compositivo e de urbanização monofuncional. Uma nova identidade urbana surgia contrapondo-se a visão monumental de uma totalidade técnica e racional, desprovida de referências simbólicas. A visão crític a da mistific ação da utopia corbusiana, do simbolismo propagandista e da mensagem modemista, entende a cidade não a penas como objeto manufa tura do, mas também como uma obra de arte coletiva.

A condição antropológica como símbolo e metáfora - identidade e significado - fizeram surgir uma nova forma de empirismo psicológico proporcionado por dois modelos que se aperfeiçoaram no processo de construção de espaços: modelos semiológicos e modelos morfológicos.

\footnotetext{
${ }_{9} \mathrm{O}$ que se define nestas linhas é o valor dos lugares produzidos pelo encontro de energias atuais, graças à força de dispositivos projetuais capazes de provocar a extensão de suas ondulações e a intensidade do choque que sua presença produz.

10 É a substituição do empirismo psicológico, fundamentalmente da psicologia da percepção gestáltic a pela fenomenologia hussenliana a que proporá a substituição da noção de espaço para de lugar.
} 
Os modelos semiológicos se expressam através dos signos, da forma urbana como meio comunicante na qual se interpõem mensagens de distintos graus de complexidade, transferência de signific ados existentes nas formas construídas da cidade. A cidade semiológica é cultural, subjetiva e abstrata. São propriedades sintáticas e semânticas da arquitetura como linguagem urbana, como expressão de um meio cultural: gramática arquitetônica e urbana nas quais os elementos estão dispostos segundo leis determinadas, uma ordem lógica. (ALVES, 2006)

A cida de como construção e configuração morfológica reforça o fato de que é uma realidade concreta, formal, física, técnica e cultural, colocada no espaço natural como contexto. Pode-se dizer que a morfologia estabelece a ordem material da forma urbana, a disposição e relações dos elementos no espaço, bem como suas caracteństicas construtivas e perceptivas como dimensão ou forma. Esse modelo diferencia-se pelo seu grau de abstração e operacionalidade, sendo caracterizado por sua conceituação, sua aplicabilidade, seus elementos, suas tipologias ou paradigmas. (ALVES, 2006)

“A forma dos lugares é o meio mais importante de emissão de informações para a realização do conceito de espaço e, em sua recepção e interpretação, age, predominantemente, o sistema visual." (KOLHSDORF, 1996, p 72)

O espaço da cidade contemporânea requer posturas que busquem responder a novas questões de configuração e conformação de sua pa isagem. Na óptica de uma relação dialética, construir a cidade é produzir espaços públicos e privados como suporte dos processos socia is que se encontram no limite entre projeto e apropriação cultural. 


\section{Utopias e Iimites do projeto urbano}

O conceito de lugar na contemporaneidade é resultado de experiências e utopias urbanas que moldaram e moldam a conformação das cidades, e do pensamento teórico e crítico de como produzir o espaço ideal. A noção de espaço com uma categoria própria da arquitetura é uma noção modema, como afima Solá-Morales, e as utopias derivadas deste movimento repercutem na recente transfomação da paisagem.

A constante necessidade de promover o debate das questões urbanas fez com que, em cada momento específic o da história, as soluções apresentadas pelos pensadores urbanos se destacassem pela foma como se posicionaram contra o pensamento vigente, ou como foram incorporadas pela prática da produção espacial. Em um último ensaio dessas utopias, a preocupação com os recursos natura is promoveu um intenso debate sobre novos modelos de produção urbana e arquitetônica, visando à reconstituição da natureza segunda.

Desenhar, deteminar, inscrever as marcas da sociedade, e perpetuar o presente em tempos futuros, toma o desafio de qualificar o espaço ainda mais instigante. Algumas utopias, por assim dizê-las, merecem destaque para esta análise, pois sintetizam o modelo de conformação espacial que se objetiva estudar, a urbanidade nas unidades de vizinha nça de Palmas, entre elas: o conceito das Unidades de Vizinhança e suas influências no Movimento Modemo; e o mais recente Novo Urbanismo. A seqüência cronológica existente, as similaridades de problemas enfrentados, e a evolução dos paradigmas de espaço e sociedade no pensamento urbanístico, fazem destes movimentos essenciais para a conformação do espaço.

O crescimento das cidades ocorreu à medida que o desenvolvimento econômico e tecnológico permitiu a expansão das malhas urbana. Em meio a esse panorama, o conceito de cidade desenvolvido por Ebenezer Howard, antecessora e influenciadora do conceito das Unidades de Vizinhança, teve um importante papel na conformação das cidades no séc. XX e opondo-se 
a prática progressista ${ }^{11}$ com que o espaço urbano estava sendo idealizado. As Cidades J ardim podem ser consideradas um dos principais exemplos de utopia urbana e tentativa de qualificar o espaço conferindo-lhe uma interação entre cidade, campo, sociedade e paisagem. Iniciada na Inglaterra no fim do séc. XIX, foi constituída com o intuito de disciplinar e qualificar o crescimento urbano, complementando o ideal dos Garden Suburbs. O avanço tecnológico dos transportes rápidos possibilitava uma nova expansão teritorial, viabilizando o deslocamento por longas distâncias.

\begin{abstract}
"A visão utópica de Howard foi uma tentativa de resolver os problemas de insalubridade, pobreza e poluição nas cidades por meio de desenho de novas cidades que tivessem uma estreita relação com o campo. Ele apostava nesse casamento cidadecampo como forma de assegurar uma combinação perfeita com todas as vantagens de uma vida urbana cheia de oportunidades e entretenimento juntamente com a beleza e os prazeres do campo." (ANDRADE, 2003)
\end{abstract}

Mesmo havendo uma crescente oferta de empregos na cidade, a realidade urbana não era favorável: poluição, insalubridade, crescimento desordenado, falta de espaços naturais. Estes fizeram com que os antigos moradores do campo, agora nos centros urba nos, a spirassem por locais com qualidade. O ideal das Cidades Jardim baseou-se em uma fusão do que haveria de melhor entre os dois meios, formando uma cidade com aspectos de campo.

Estas a presentavam como proposta urbana, um traçado bem definido e uma preocupação com a escala dascidades. O modelo adotado seria o radial circular, com seis bulevares radia is e um parque central para impedir a especulação imobiliária. Logo após encontrava-se uma área verde, com comércio e, em seguida, uma grande avenida junto às áreas residenciais. Como sistema de transporte de ligação, fora proposto uma rede de trilhos, formando um conjunto de núcleos de cidades interligadas, e entre elas, áreas de cultivo e de plantio.

${ }^{11}$ Denominação feita por Françoise Choay para caracterizar algumas comentes do urbanismo dentre elaso modemismo. 
Acreditava-se que as qualidades do urbano e do campo, de espaços livres, da paisagem pitoresca, e da incorporação de um desenho urbano mais adequado, poderiam intensificar as relações sociais e promover interfaces entre o construíd o e o livre, e entre as diferentes classes soc ia is. A utopia de solucionar os problemas enfrentados no fim do séc. XIX transcendeu o país de origem de criação, passando a configurar inúmeros planos para novos assentamentos, e novas cidades que se espelharam nos princípios deste movimento.

Trazer de volta as relações sociais perdidas com o vertiginoso crescimento dascidades, e proporcionaraosmoradores uma interação com os equipamentos urbanos do cotidiano próximos de sua moradia, foram os principais condicionantes para a elaboração do movimento das Unidades de Vizinhança. Essa idéia, embora se preocupasse mais com as áreas residenciais, e não com a totalidade da cidade, absorve muito dos conceitos das Cidades jardins, principalmente quando é projetada a comunidade Forest Hill no estado de Nova York, decisivo para a elaboração dosconceitos elencados por Pemy12.

\begin{abstract}
"O conceito de Unidade de Vizinhança nasce com duas preocupações principais. A primeira, com a distribuição dos equipamentos de consumo na escala da cidade - e aí a escola aparece como foco das atenções, inclusive por ser um dos motivos geradores da concepção. A segunda preocupação, refere-se ao anseio de recuperação de valores de uma vida social a nível local (relações de vizinhança), considerados enfraquecidos ou mesmo perdidos com as transfomações por que passou a vida urbana em decorrência dos processos espaciais e sócio-econômicos oc asiona dos pela Revolução Industrial." (BARCELOS, 2001)
\end{abstract}

As noções de centralidade e de escala são as principais características deste movimento, que tem como anseio, a recuperação da

\footnotetext{
12 O conceito tem origem no início do séc. XX por estudos de sociólogos americanos, como Park e Burgess, Horton Cooley, Woods e Ward que verificam o enfraquecimento das ligações socia is nas cidades de rá pido crescimento, substituídos por relações ind ireta s entre os cidadãos. Nos a nos vinte, o americano Cla rence Pemy, a o estudar as relações entre habitantes e os equipamentos, apresenta um conjunto de trabalhos sobre a unidade de vizinhança. Ele parte da convic ção de que os principais equipamentos devem situar-se próximo as habitações, em terreno que designa de the family neighborhood - ele acreditava que a vida social se desenvolve graças à utilização de serviços comuns. (LAMAS, 1993)
} 
vida social em um pequeno fragmento da totalidade da cidade, onde se esperava que seu morador pudesse desenvolver as práticas citadinas, através de relações e interações com os moradores desta vizinhança. A preocupação com a localização e dimensão das escolas como principal centralidade, acessível aos moradores de seu entomo e capaz de aglutinar a comunidade, foi a principal premissa de Pemy. A idéia de UV é de extrema singeleza: constatando que as relações socia is entre vizinhos, que existiam nos antigos bairros, tendem a desaparecer nas novas urbanizações e grandes metrópoles, pretendia-se recriá-las através do planejamento urbano. (LAMAS, 1993 p 317)

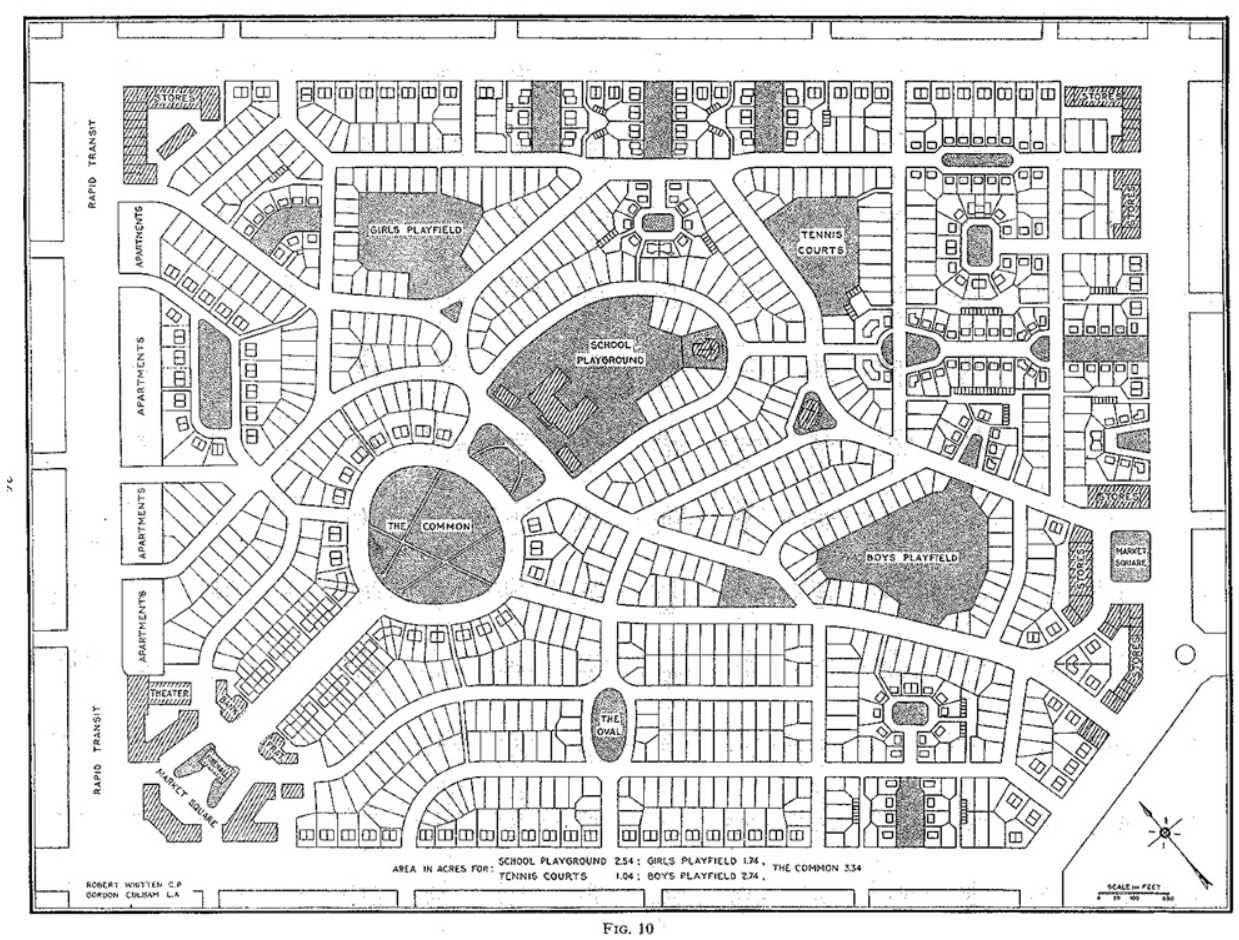

Fig. 01, Modelo de Unidade de Vizinhança de Pemy. (Fonte: BENÉVOLO, 1999)

Resgatar a civilidade no espaço urbano, proporcionando um ambiente capaz de promover as interações entre vizinhos, deveria ser desempenhado pelo projeto, que permitisse ao morador o reconhecimento como pertencente àquele espaço. Se a cidade do início do séc. XX sofria os impactos negativos da era pós-industrial, a ciência urbana que surgia seguia 
modelos sociológicos ${ }^{13}$ para enfrentar tais problemas. As unidades foram idealizadas por Perry a partir de seis elementos princ ipa is:

1. Tamanho: Uma unidade de vizinhança deve prover habitações para aquela população a qual a escola elementar é comumente requerida, sua área depende da densidade populacional.

2. Limites: A unidade de vizinhança deve ser limitada por todos os lados por ruas suficientemente largas para facilitar o tráfego, ao invés de ser penetrada pelo tráfego de passagem.

3. Espaços Públicos: Um sistema de pequenos parques e espaços de recreação, planejados para o encontro e para as necessidades particulares da unidade de vizinhança devem ser providenciados.

4. Áreas Institucionais: Locais para escola e outras instituições tendo a esfera de serviço coincidindo com os limites da unidade de vizinhança, devem ser adequadamente agrupadas em lugarcentral e comum.

5. Comércio Local: Um ou ma is locais de comérc io adequadosà população devem ser oferecidos, de preferência na junção das ruas de tráfego e adjacente a outro similar comérc io de outra unidade de vizinhança.

6. Sistema Intemo de Ruas: A unidade deve ser provida de um sistema especial de ruas, sendo cada uma delas proporcional à provável carga de tráfego. A rede de ruas deve ser desenhada como um todo, para facilitar a circulação interior e desencorajaro tráfego de passagem.
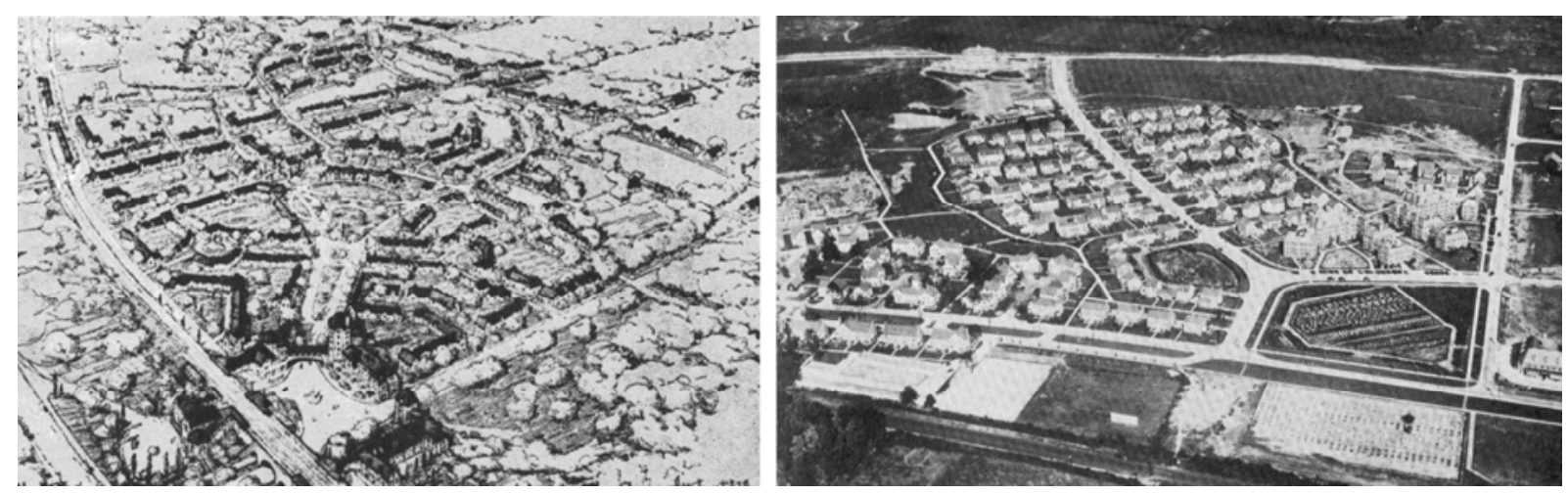

Fig. 02, Plano de Forest Hill e implantação de Radbum - marcos do pensamento das Unida des de Vizinhança. (Fonte: BARCEШOS, 2001)

\footnotetext{
13 Aos autores que teorizaram interessava mais as questões socia is e organização funcional, do que as referências dos traçados da cidade. Foi extremamente difundido a partir dos anos vinte e principalmente no fim da II guerra onde a necessidade de dispor de novas áreas habitacionais e a discussão do urbanismo levaram a a mpla utilização do conceito. (LAMAS, 1993)
} 
Se Perry teorizou sobre o tema, coube a Clarence Stein e Henry Wright a primeira aplicação prática do conceito em Radbum. Depois de grande divulgação em meio aos planejadores americanos, o conceito chega à Europa, principalmente depois da II Guerra Mundial, tendo uma grande aceitação, principalmente na Inglaterra, graças à semelhança com os conc eitos propostos pelas Cidades J ardins.

Foi em Chandigarh que a Unidade de Vizinhança ganhou visibilidade no movimento Modemo, fazendo com que Le Corbusieradotasse o conceito para o projeto urbano da cidade. As unidades foram definidas a partir de uma estrutura em xadrez de grandes vias hierarquizadas e pensadas para um trânsito rápido e mecanizado. O "setor", como preferia se referir, foi estabelecido com dimensões variando em tomo de 800 x 1000 metros, servido por um sistema intemo de vias de circulação de veículos, e dividido por uma via ao longo da qual se encontrava o comércio, e onde estavam as escolas e demais equipa mentos comunitários, numa situação que sugere certa semelhança com as soluções adotadasem Brasília. (BARCELOS, 2001)

No Brasil, uma forte presença do pensamento de Unidade de Vizinhança, embora não de foma explícita, se deu com Padre Lebret, que desenvolveu na década de 50 estudos para São Paulo. O senso comunitá rio e o ideal de unidade para o planejamento, remetem aos princípios desse movimento. Os conceitos desenvolvidos por Lebret se diferem dos utilizados posteriomente por Lúcio Costa, que a presentam uma visão ma is progressista do projeto urbano.

Este modelo se concretizou de forma mais efetiva no movimento Modemo através do plano para Brasília, onde as superquadras utilizaram os conceitos de limites e tamanhos definidos para as áreas residencia is e a disposição de equipamentos urbanos junto às moradias. O diferencial modemista está na forma como as habitações foram idealizadas e implantadas em cada célula. Elevar os blocos por pilotis foi uma forma de libertar a edificação do solo, e estimular o fluxo de pedestres por toda a superfície das superquadras, fazendo com que houvesse uma interface 
direta, livre e pública, entre os elementos urbanos que compõem cada quadra.

\begin{abstract}
"As superquadras residenciais, assim designadas não tanto por se pretenderem superiores mas porque são grandes, agrupando-se em número de quatro, constituindo cada conjunto uma unidade de vizinhança autônomas, com escolas, comércio local, facilidades de recreio, etc. O tráfego motorizado é delimitado e contido nas áreas intemas de acesso aos blocos residenciais e respectivo estacionamento; todo o restante da quadra, inclusive a periferia arborizada é privativa dos pedestres - gente, portanto, e as mães, distantes seis mil milhas de Harlow poderão ver os filhos correr sem nisco para a escola." (LÚCIO COSTA, citado por BARCELOS, 2001)
\end{abstract}

A utilização de Unidades de Vizinhança para configurar um traçado modemo, com avenidas de circulação expressa e áreas dedicadas a monumentalidade, criou um condicionante urbano intrigante em Brasilia. Ainda na atualidade, discute-se a qualidade do seu projeto, onde aspectos positivos das superquadras, como a fluidez, a diversidade de serviços e a quantidade de espaços livres, são confrontados com aspectos negativos proporcionados pelo plano, como a escala não gregária, a perda identitánia, a monumentalidade como forma de legitimar o espaço do poder, e a perifenização de grande parte da população nas cidades satélites, às margens do plano diretor.

Mesmo com Chandigarh sendo construída na índia, é em Brasilia que os conceitos do movimento modemo irão ganhar notoriedade e a lavancar a discussão sobre produção do espaço e interação social. O Estigma de cidade onde as relações são "frias", sem profundidade, ainda marca a imagem urbana da capital, porém pesquisas recentes rea lizadas indicam a satisfação de seus habitantes, estando em primeiro lugar no que tange a qualidade de vida. Dois aspectos são relevantes nesta questão; as relações socia is na escala da unidade, que ocorrem de forma intensa, e na escala do plano como um todo, onde as referências identitárias se perdem em meio à monumentalidade do projeto. 

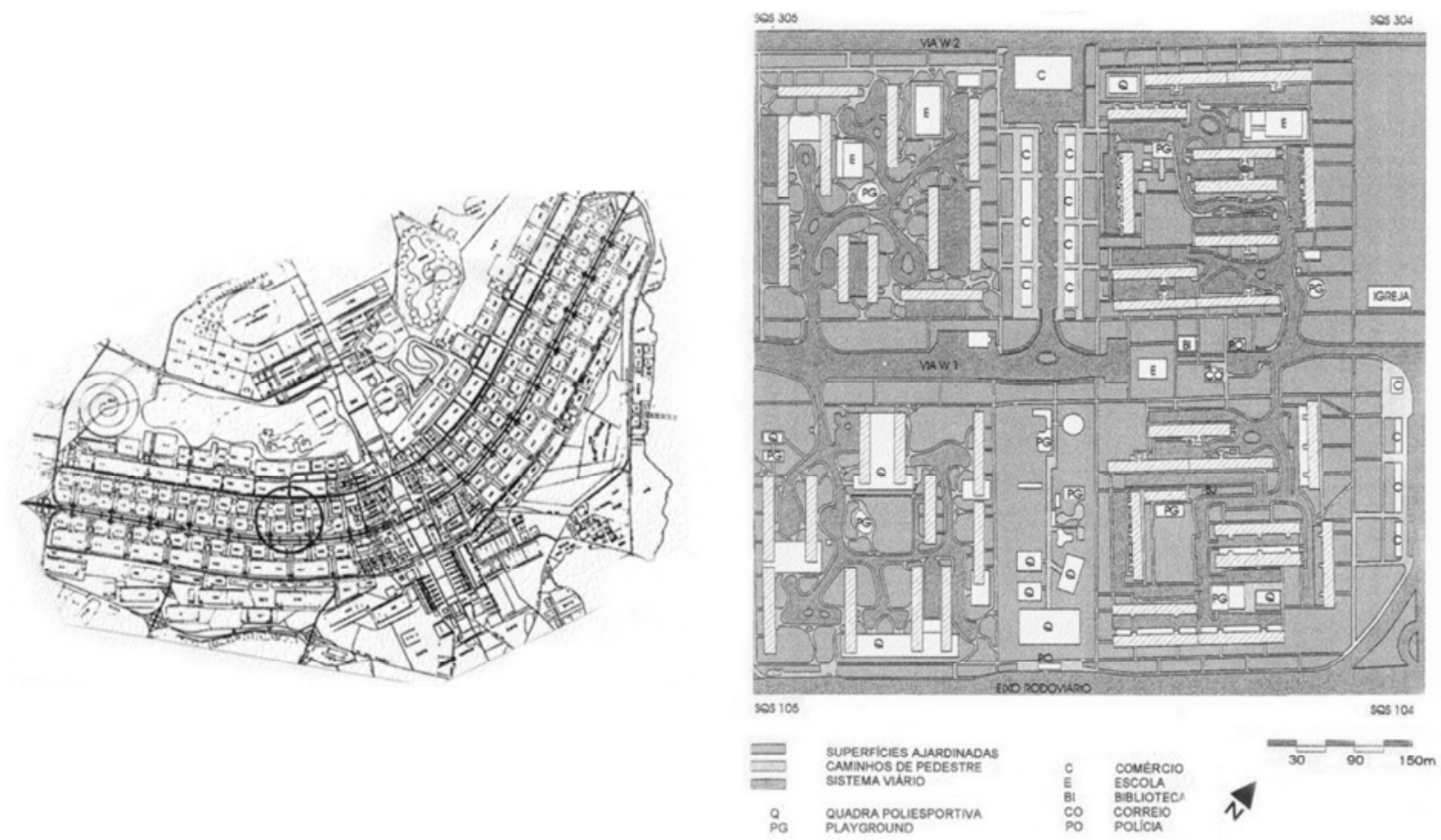

Fig. 03, Unida de de Vizinhança de Brasilia. (Fonte: BARCEШOS, 2001)

A perda da escala gregária não é si uma conseqüência exclusiva do movimento modemo, mas sim do espalhamento urbano, que intensificou a ocupação fora dos limites dos centros das cidades, em busca de novos horizontes espac ia is que denotassem qua lidade.

Uma utopia recente, que se difundiu resgatando valores comunitários das cidades tradiciona is americ anas, é o do movimento do Novo Urbanismo. Ironicamente, o termo "novo" é utilizado para demonstrar uma concepção atual, de como ordenar as cidades, tomando como base conceitos e métodos tradicionais de desenho de vizinhança, referentes ao peńodo anterior à Segunda Guerra, sustentada pelo fato de que estas produziram espaços com qualidade e de boa convivência humana. Esta "nostalgia", atribuída à maioria dos articuladores do movimento, originou uma das principais correntes de planejamento urbano do Novo Urbanismo, conhecido por Tradicional Neigborhood Development. Um dos principais objetivos desta, é enfatizar o sentido de vizinhança e participação das pessoas junto à comunidade, com responsabilidade ambiental e sentido de pertencimento a o local. 


\begin{abstract}
"Neighborhoods should be compact, pedestrian friendly, and mixeduse. Districts generally emphasize a special single use, and should follow the principles of neighborhood design when possible. Comidors are regional connectors of neighborhoods and districts; they range form boulevards and rail lines to rivers and parkways." (CONGRESS FO R THE NEW URBANISM, 2000)14
\end{abstract}

Uma segunda corrente no Novo Urbanismo é conhecida por Transit Oriented Development, TOD, conceito utilizado por planejadores, que propõe comunidades estrutura das pelo deslocamento através do transporte público e do caminhar. Para que isto ocorra é preciso que haja distâncias curtas para os afazeres diánios e caminhos a gradá veis para que as pessoas deixem seus carros em casa. Redefinir o desenho da cidade é desmistifica ro sonho americ ano de vida e prover mais acessibilidade para todos, com base nos princípios da igualdade. Segundo Walter Kulash, muitas atividades da vida diária podem serfeitas a pé, gerando independência para aqueles que não dingem, especialmente os idosos e jovens. Redes conectadas de ruas podem ser desenhadas para encorajar caminhadas, reduzir o número de viagens de automóveis e conservar energia.(CONGRESS FOT THE NEW URBANISM, 2000)

Uma comunidade de Transit Oriented Development é caracterizada por apresentar um alto grau de responsabilidade no âmbito do projeto urba no, prioriza nd o conceitos, dentre os qua is podem ser elenca dos:

1. Organizar a cidade em um nível regional para ser compacta e suportar o trânsito;

2. Locais comerciais, moradia, empregos, parques e usos cívicos com distâncias caminhá veis e prover um misto de tipos de casas, densidadese custos;

3. Criar rede de nas "amigas" do pedestre que conecta diretamente destinos locais;

4. Produzir espaç os públic os e orientar construções e ativida des de vizinhança;

5. Preservar o habitat, zonas ribeininhase alta qualidade de espaços a bertos.

O projeto para o Novo Urbanismo representa o principal elemento de execução de suas propostas, trabalhando com diversas soluções e formas

\footnotetext{
14 Vizinhanças podem ser compactas, amigas do pedestre, e uso misto. Distritos geralmente enfatizam um uso simples especial, e podem seguir os princípios do desenho de vizinhança quando possível. Corredores são ligações regionais de vizinhanças e distritos, percomidos por bulevares e caminhos de parquese linhas de trem: tradução do autor para o texto do Congress for the New Urbanism.
} 
de implantação urbana e arquitetônica. O uso misto e a organização do espaço pelos deslocamentos, são os principa is fatores de composição para os diferentes tipos de atividades que serão exercidas em uma área. Estipulou-se uma medida ideal para uma comunidade em tomo de 600 metros de raio do centro geográfico, destinada à referencial local e ao centro comercial, sempre junto a linhas de corredores de ônibus, transporte de massa ou vias arteriais. Essa distância organiza a comunidade para a possibilidade de não utilização o carro.

As áreas localizadas fora do diâmetro de uma TOD, chamadas de secundárias, sofrem influência direta e podem seguir o mesmo modelo do traçado, utilizando os serviços locais para as necessidades diárias. Os elementos urbanos foram separados em itens seguindo os tópicos estipulados, de acordo com a divisão de Peter Calthorpe: Guias Principa is; Ecologia e Habitat; Áreas Comerciais; Áreas Residencia is; Áreas Secundárias; Parques, Praças e Edifícios Cívicos; Sistemas de Circulação; Pedestres e Sistema de Ciclovia.
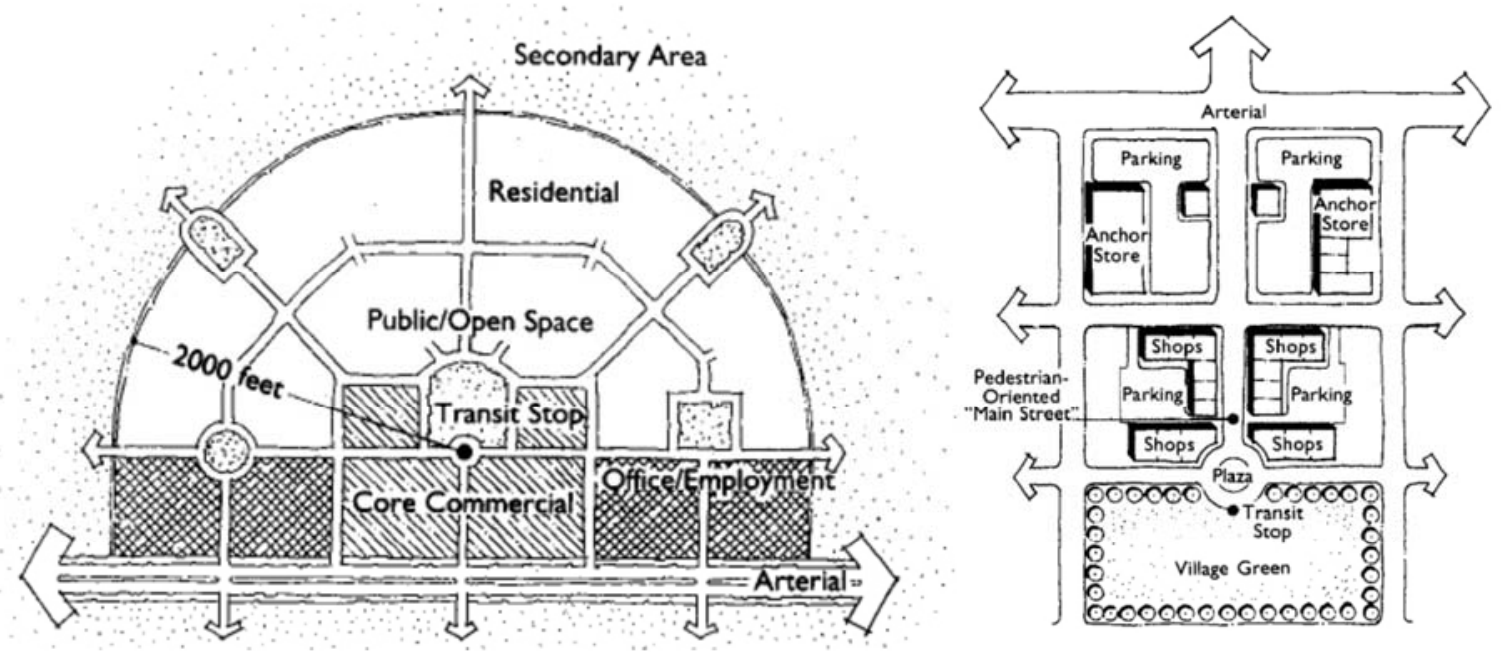

Fig. 04, Plano piloto da TOD, e detalhe de seu centro comercial. (Fonte: CALTHORPE, 1993)

Devido à sua posição geográfica, a área comercial é a articuladora do projeto urbano, localizando-se no centro da TOD e perto dos pontos de parada dos meios de transporte de massa. O uso residencial complementa os outros componentes propostos para essa comunidade, fazendo com que 
a população usufrua de um ambiente com boa qualidade urbana, proporcionada por uma diversidade de opções de moradia, tanto no que tange às tipologias das edificações, quanto pela densidade pretendida para cada situação.

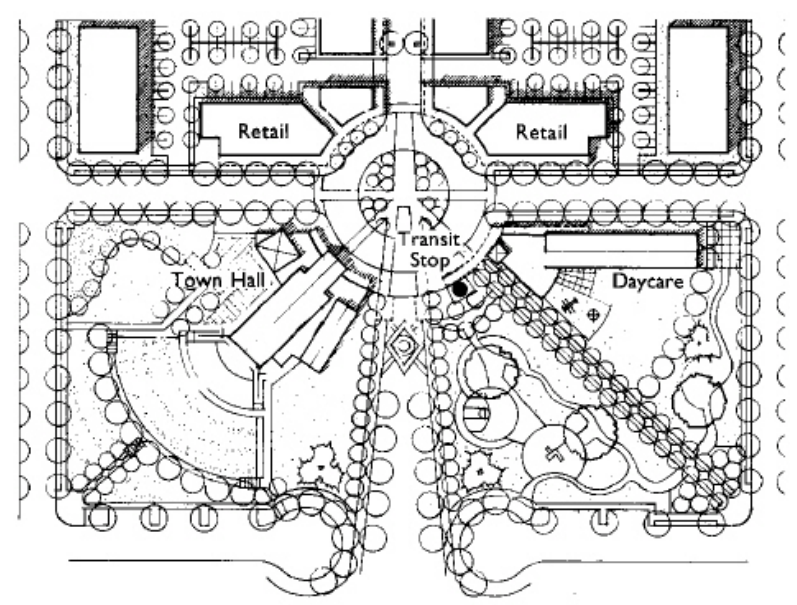

Fig. 05, Organiza ção dos espaços livres e área comercial: TOD. (Fonte: CALTHORPE, 1993)

As praças e parques são espaços públicos de convivência para cada vizinhança, localizadas junto às ruas, abrangendo cada setor da comunidade. Cada uma delas, desenvolve uma função: nas áreas residencia is é um espaço de lazer, podendo ser usada para separar edifícios da rua e também amenizar o clima local. Os parques podem estar locados em tomo das áreas secundárias, com grandes espaços abertos para diferentes atividades, e espaços de preservação de espécies nativas e eventua is corposd'água.

Um dos principais objetivos do Novo Urbanismo é diminuir o uso do carro. As ruas apresentam o mesmo papel de qualquer projeto urbano, porém, seu desenho tem o intuito de limitar o uso do veículo, utilizando artifícios de redução de velocidade, para melhor segurança do pedestre e do ciclista. O sistema de circulação de pedestre é feito pelas calçadas, que devem ser largas, principalmente nas áreas comerciais, e devem ser um local de passeio e de convívio, com a implantação de mobiliário urbano e diversos equipamentos públicos, propiciando ambientes urbanos com qualidade. 

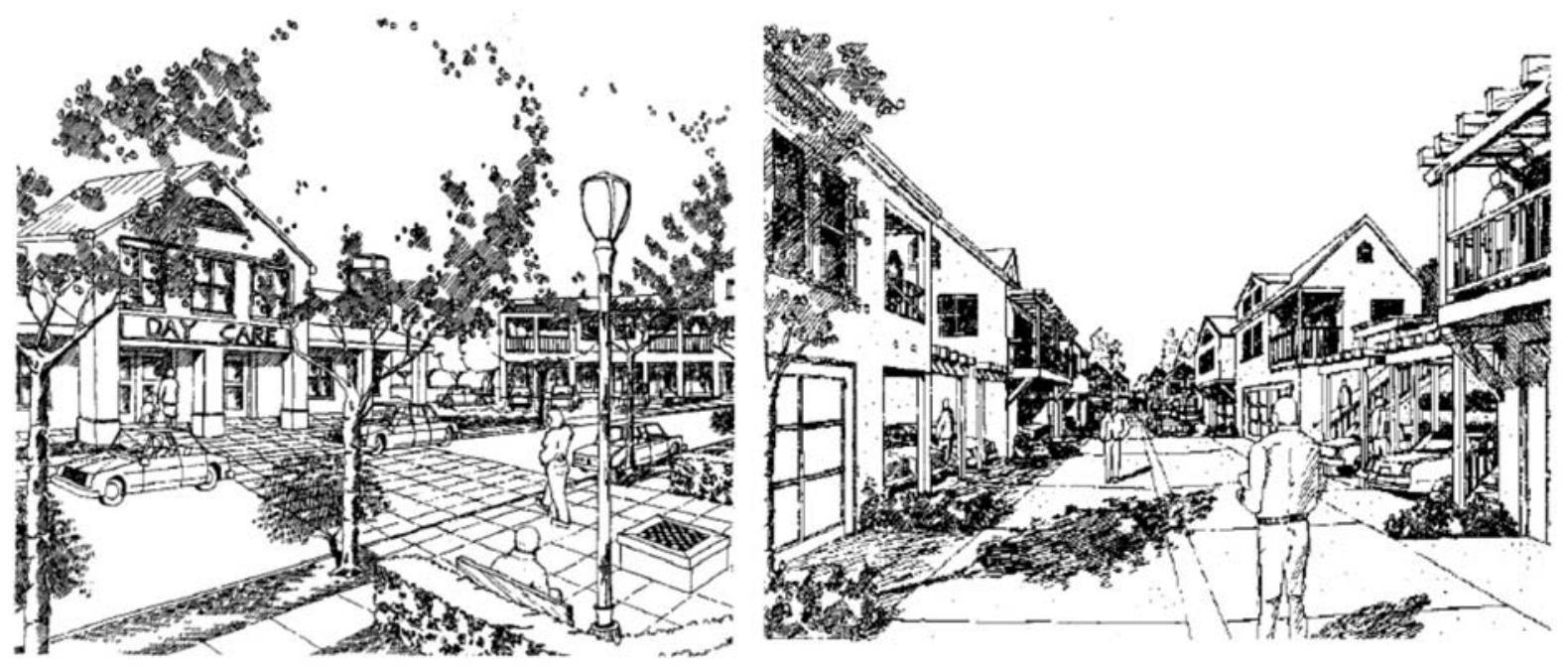

Fig. 06, Ruas e calçadas; Ruas a trás das casas. (Fonte: CALTHORPE, 1993)

A segunda corrente, a TND, fundamenta seu traçado urbano nos antigos valores e padrões de vizinhança, sem a Imejar montar uma "réplica", mas sim trazê-los para a atual realidade. Nesta proposição, o centro da cidade exerce o papel de referencial do projeto, representando o local de realização das atividades culturais, sociais, religiosas, lojas, escolas e escritónios. As áreas de moradias ficam ao redor deste centro, a cessíveis por meio de transporte sustentável. O traçado diferencia-se do convencional estilo americano, permitindo um dinamismo maior entre os diversos setores que compõem a cidade (Fig. 07).

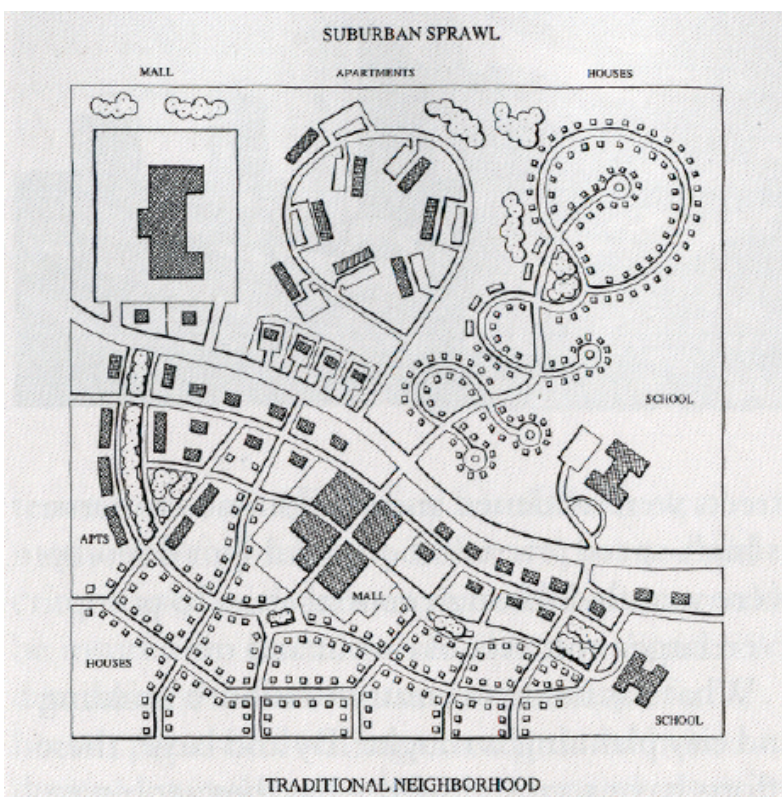

Fig. 07, Plano TND. (Fonte: KATZ, 1994) 
O conceito do Novo Urbanismo resgata pressupostos de interação social composto nas unidades de vizinhança, e de um desenho urbano que mescla atividades e usos para permitir o funcionamento de cada célula como uma unidade capaz de suprir as demandas diárias da sociedade, e assim a umentar as relações entre os mora dores nesses espaços. J a ne J a cobs é uma crítica desse modelo por não acreditar que uma pequena parcela, como se fosse um fragmento da cidade, possa promover a intensidade de interações previstas. A falta de autonomia tanto econômica quanto social nos bairros é natural e necessária a eles, simplesmente porque eles são integrantes das cidades. (J ACOBS, 2000, p 128)

As utopias dos lugares consolam, as heterotopias dos não-lugares inquietam. Em cada momento da história os limites do projeto buscavam desenhar o espaço de forma a gerar condições não somente de habitabilidade, mas de sociabilidade perdida pelo crescimento e pelas novas formas de apropriação do espaço público, interferindo na esfera cultural que incide sobre ascidades. A busca de uma nova urbanidade não consola e nem inquieta, mas desafia os limites do projeto na conformação de lugares.

\section{Caminhos da urbanidade}

A dialética entre projeto e apropriação se evidencia nos limites existentes entre a formalidade e a urbanidade do espaço. Este não é qualitativo somente pela sua imagem e caráter projetual, mas pela intensidade de interações sociais que este possibilita. Esta qualidade do espaço urbano conforma lugares, locus identitánio e da expressão cultural das sociedades.

Se sua produção pode ser entendida sob uma dupla perspectiva - a da sua homogeneização e da fragmentação - compreender esses limites significa projetar o espaço público das manifestações e contestações cultura is, tomando-o novamente político e democrático. 
O espaço é uma ciência nas quais objetos concretos e abstratos caminham la do a la do em incursões filosófic as, tec nológicas, físic as, cultura is e ambientais. Essa complexidade incide na principal problemática dos planejadores urbanos - como tomar novamente o espaço público, ou do público como afirma Augé, no lugarda urbanidade? Será ainda possível um lugar público ideal? O lugar é identitánio e único porque é constituído por uma seleção específica de representa ções cultura is. (AUGÉ, 1994, p 70)

Lugar e não-lugar sobrepõem-se, coexistem, sendo que a objetividade do não-lugar transfoma o lugar subjetivo e os vínculos simbólicos. Cada lugar é determinado pelos movimentos da sociedade e pelas diferentes relações socia is que se apropriam dos espaços, constituindo e conformando as cidades. (ALVES, 2006)

O ambiente urbano não é uma reprodução derivada apenas do projeto urbano, mas de seus limites, contraposições e relações entre as diferentes dimensões que o compõem. O reconhecimento da importância da relação entre as várias componentes do ambiente urbano é deteminante para a reflexão sobre a especificidade disciplinar. (G IANG REG ORIO , 2000, p 05)

Os limites não são somente as bordas, as tangentes entre as dimensões, as interfaces existentes entre cada instância do projeto urbano, ma is ta mbém, as barreiras, os contrapontos e as possibilida des existentes em cada elemento que constitui e conforma o espaço. Assim como afima Heidegger (1994), limite não é onde algo se acaba, mas sim, como disseram os gregos, onde algo começa seu ser.

Jane Jacobs afima que a cidade é um imenso laboratório de tentativa e erro, fracasso e sucesso, em temos de construção e desenho urbano. É nesse laboratório que o projeto urbano apreende, elabora e testa seus modelos, e onde ocorrem as mais efetivas expressões do viver em grupo, das manifestações sociais do cotidiano e da exaltação da cidadania.

Alguns modelos pautam-se em fómulas e práticas onde as expressões do cotidiano, as inscrições do espaço, e a confomação da esfera pública 
são subjugadas à funcionalidade do espaço, negligenciando a diversidade e as contradições da esfera cultural urbana. O tecnicismo exclui qualquer possibilidade de qualificar a paisagem através de seus lugares, elimina as contra dições do cotidiano, a riqueza de relações sociais que só o projeto e o uso do espaço público podem revelar. (LEITE, 1998, p 73)

O principal palco dos conflitos e contradições são as ruas, locais onde historicamente as tramas urbanas e sociais das cidades se conectam. 0 espaço público, como lugar de elaboração do debate público, não pode encontrar-se nos não-lugares contemporâneos, de passagem e vazios de significados, senão a custa da distorção do sentido do adjetivo público. (ALVES, 2006)

Assim como afirma Carlos (1996, p 131) as ruas da metrópole revelam comportamentos que nos ajudam a entender um pouco do que acreditamos ser a construção de algo que talvez possa ser chamado de "nova urbanidade".

O espaço público é segundo Deutsche não só uma simples referência a algo existente, localidades físicas urbanas como parques, praças, ruas e áreas públicas, mas local onde os cidadãos se engajam no debate, onde os direitos são declarados, e onde a identidade dos grupos sociais e a identidade da sociedade são ambas constituídas e questionadas. (1998, p 03)

Pensar em uma nova urbanidade é compreender os limites entre a vida pública, baseada nas manifestações da coletividade, e da vida privada, baseada nas manifestações segregarias imposta pelos novos modelos de individualização. A cidade é um fato cultural, e assim sendo, cabe aos planejadores, cientistas, arquitetos e ecologistas entendê-la por este viés, para poder aplicar novos modelos de construção e configuração de cidade baseando-se em premissas que promovam o espaço do público e para o público.

Para Frederico Holanda, professor da UNB e organizador do livro Arquitetura e Urbanidade, a sociedade existe ao longo dos limites entre Formalidade e Urbanidade, distintas em diferentes dimensões. A primeira 
colocada por ele se dá na definição colocada pelo dicionário, onde formalidade é definida como não espontâneo, enquanto urbanidade, qualida de de cortês, civilida de.

A espacialização das duas também apresenta distinções, principalmente quanto à forma. A formalidade se caracteriza por enomes espaços abertos; inúmeros espaços cegos, mortos e residuais; e um forte isolamento entre o dentro e o fora (Privado e Público). Em contrapartida, a urbanidade se caracteriza por pequenos espaços abertos; espaços ric amente a limentados por entradas; e ambigüidade entre dentro e fora.

Socialmente também apresentam características diferenciadas. Na formalidade, a sociedade caracteriza-se pela segmentação de pequenos grupos de iguais; pela especialização; pela impermeabilidade entre segmentos sociais e por ma is desigualdade. Novamente em contraposição, a sociedade da urbanidade se dá pela continuidade de grandes grupos de diferentes; pela negociação contínua de papéis; pela mobilidade social e pormais igualdade.

O conceito de urbanidade colocado por Holanda revela a dialética entre espaço e sociedade, objetivando não somente uma qualidade espacial, mas das interações socia is que se originam. Ruben Pesci, a utor do livro La Ciudad de la Urbanidad (1999), discute oscaminhose processos para alcançar a urbanidade nas cidades, contestando os problemas das cidades inurbanas ${ }^{15}$. Uma questão permeia o trabalho dele: é possível o renascimento da civitas? Embora ele cite os constantes erros urbanístic os e políticos, para ele existem exemplos que implicam em uma melhor qualidade de vida promovida principalmente por novos valores da humanidade. Segundo Pesci, a cidade da urbanidade seria alcançada pela união de princípios constituídos por:

- A descentra liza ção e a multifocalidade como uma nova organização;

- A cidade como um sistema de interfaces;

- Os espaços a bertos e sua contra posição com os espaços fechados;

\footnotetext{
15 Conceito colocado por Pesci no livro La Ciudad Inurbana, 1985.
} 
- A participação social e a identific ação dos atores sociais;

- Osfluxos como a essência do funcionamento urbano;

- Osprocessos produtivos urbanos.

A urbanidade é um adjetivo do espaço urbano, promovida em parte pela inter-relação dos parâmetros elencados por Pesci, com a adição de elementos que compõem o debate sobre o espaço público, a conformação de lugares, e os sistemas de espaços livres promovidos pela forma urbana. ̇̀ resultado das forças cultura is que imprimem no espaço as escritas do ser humano, conformando a paisagem da cidade contemporânea.

\begin{abstract}
“A cidade contemporânea deve ser interpretada por construções teóricas e estéticas da urbanidade contemporânea que explicitem os fenômenos de temitorialização e destemitorialização, temporalidade e efemeridade e outros, em relação a seus espaços públicos, cenários e atores urbanos - operando com formas de urbanidade emergentes na contemporaneidade e suas complexidades sócio-culturais, a noção de paisagem e sua qualidade de linguagem de conotação ambiental, social e pública, contra stando os disc ursos hegemônic os e as textua lida des da cultura do loc al." (ALVES, 2006)
\end{abstract}

O projeto urbano esbarra nos limites da cidade ideal, que insere utopias do desenho no espaço na tentativa de qualificá-lo como lugar. Porém, as múltiplas variáveis que atuam no espaço constituem novas rea lida des a poia da s em fa tores cultura is, so c ia is e a mbienta is. A urba nida de não deve se darfeita sobre um simulacro de cidade autêntica, ela deve ser autêntica.

\title{
Os limites da urbanidade
}

Os parâmetros de análise deste trabalho seguem algumas das diretrizes propostas por Pesci para a urbanidade, com modificações decorrentes das característic as e especific idades do contexto local. Entre as categorias elencadas que se originam nos estudos de Pesci estão: múltiplas centralidades, interfaces, e espaços livres e construídos. A classific ação 
epistemológica e as leituras espaciais não apresentam a mesma conformação, incorporando novos valores e subcategorias que enfatizam o conceito adotado pelo trabalho.

Duas outras categorias, a de movimentose permanência no espaço, e conectividade, resultam dos modelos de sintaxe espacial, e dos estudos de Holanda e Kolhsdorf. Para a sintaxe não foram utilizados os modelos matemáticos de programas de informática aplicados pelos laboratórios de Space Sintax, mas seus pressupostos de axia lidade e localização de fluxos no espaço.

A categoria espaços verdes surge através da discussão dos sistemas de espaços livres existente em Palmas. A sua grande quantidade formata o tecido urbano e configura a imagem de qualidade da cidade. A discussão proposta não se limita a fazer um levantamento quantitativo, mas qualitativo, da capacidade destes em se converterem em lugares.

A múltipla centralidade é o resultado de práticas socia is no espaço, que dão a ele identidade, visibilidade e legibilidade. Esta o formata como ponto convergente das diferentes ações humanas, conferindo-lhe o papel de articulador do seu entomo e das estruturas espaciais. A sua formação remete a constituição da própria urbe, onde o espaço da troca, da convergência de produtos e mercadorias, promovia os pontos no espaço geográfico que resultaram nas cidades. Segundo Heidegger a centralidade se constitui como lugar, formando parte do espa ço existencial16.

O lugar é o local onde a representatividade da vida social se manifesta e transforma o ser pertencente ao espaço. As centralidades ganham representatividade a partir de sua estruturação como ponto nodal e de articulação das atividades humanas, local de encontro de fluxos, local aglutinador de permanência e do convívio coletivo. Elas qualificam o espaço e são resulta dos do processo de constituição de lugares.

\footnotetext{
16 Paralelismo entre espaço existencial e espaço a rquitetônico, enqua nto localização da existência humana entre o céu e a terra em frente às divindades.
} 


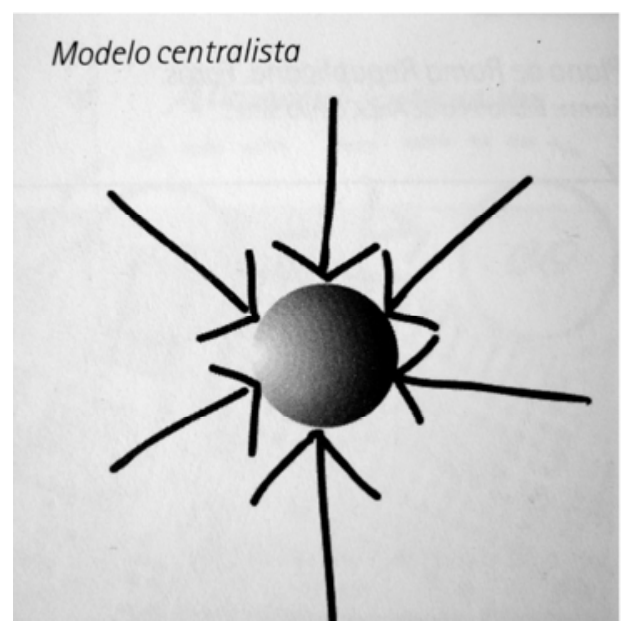

Fig. 08, Modelo centraliza do e multifocal. (Fonte: PESCI, 1999)

A urbanidade é promovida por espaços pluninucleares, condiciona do à uma rede de centralidades. Estas, cada vez ma is decorrem de uma nova dinâmica cultural, e de processos espaciais que redistribuem os novos centros seguindo padrões cultura is dos fluxos urbanos. Estas transformam a esfera pública da vida cotidiana, e propiciam aos locais da expressão cultural que imprimam suas marcas no espaço, denotando-lhe identidade, uso e qualidade.

Se um sistema de centros, multireferenciais pressupõem identidade e legibilidade, um projeto urbano mononuclear pressupõem a sua restrição, focando em um único espaço, a articulação da vida política e social de uma cidade. Se a centralização implica em concentração, a sociedade multifocal se caracteriza por diversos centros e focos de interação social, criando com isso uma diversidade de espaço essencial para a urbanidade.

\footnotetext{
“Quando socialmente vivenciada, a funcionalidade utilitánia do projeto como organização do espaço mostra sua insuficiência e ostenta a relatividade da sua mediação como organização." (FERRARA, 1998, p 28)
}

O espaço urbano projetado diferenciou-se, em vários momentos da história, pela concentração e descentralização de pontos focais nas cidades, conferindo uma gama de formas e traçados que influenciaram a esfera pública e privada nas cidades. Os limites enfrentados para a sua conformação, caracterizaram uma contraposição do projeto a favor das 
necessidades socia is e coletivas de uma sociedade. O tecnicismo ampliou a monocentralidade à medida que determinava a fragmentação do espaço pelo uso e não pelas práticassocia is.

O contraponto ao deteminismo do projeto está nos processos cultura is que as geram. Os limites do desenho estão na concepção errônea e distorcida de uma esfera pública pautada na imposição de centros para atividades coletivas.

A conectividade intensifica a multicentralidade, possibilitando a criação de um sistema de espaços livres pela cidade, capilarizando e integrando o tecido urbano e as tramas sociais que nela se dinamizam. A cidade é o ponto de máxima concentração do vigor e da cultura de uma comunidade; tem a foma e o símbolo de um conjunto integrado de relações sociais. (FRUG Oப, 1995, p 11)

A integração do espaço urbano permite às cidades intensificarem o seu papel de promotora das relações sociais em diferentes níveis. A demubada das muralhas das antigas cidades, proteção e limites de seu traçado urbano, promoveram não só uma nova configuração espacial, mas permitiram a sua expansão e conexão, tanto de sua estrutura física como de sua estrutura social, configurando novas sociedades. Hoje os limites se caracterizam por outras barreiras, tanto físicas como sociais, definindo fragmentosque restringem o espaço de exercer sua interação.
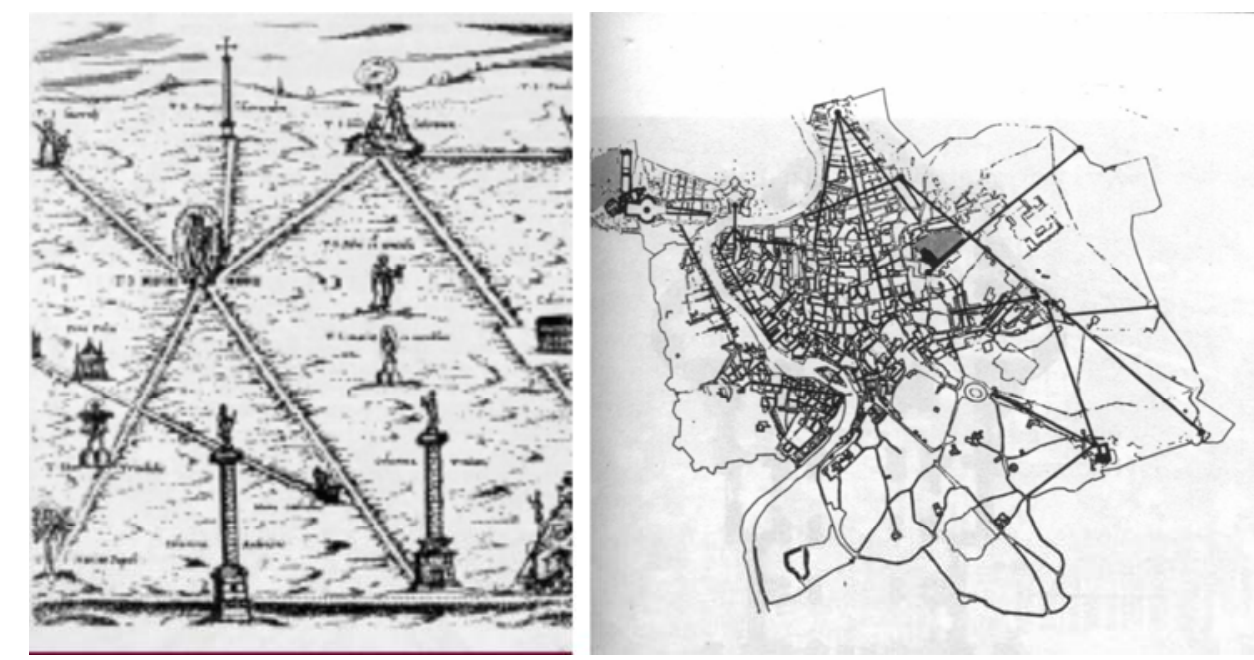

Fig. 09, Planta de Roma mostrando as a venidas abertas por Sisto V. (Fonte: BENÉVOLO, 1999) 
A partir de Roma de Sisto V, passando pela Paris de Haussmann, por Washington de L'Enfant, pela Ringstrass de Viena e até chegar a o séc. XX, 0 urbanismo se deparou com a tarefa de reorganizar o espaço da cidade através da conectividade. O papa Sisto V promoveu uma importante refoma em Roma, com o objetivo de ligar os principais pontos da cidade, conectando-os por avenidas, unindo a cidade medieval às áreas menos povoadas, promovendo a sua vitalidade.
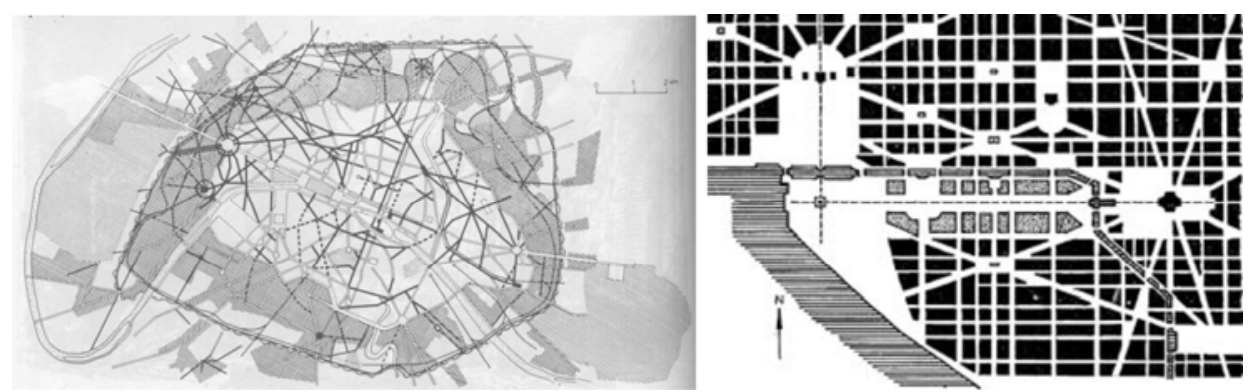

Fig. 10, Abertura das avenidas em Paris e projeto de Washington: maior conectividade. (Fonte: BENÉVOLO, 1999)

A conectividade esteve presente também nos planos do prefeito Haussmann. A proposta para Paris se deu em cima de uma cidade também já consolidada, assim como Roma, que cresceu além dos limites de sua muralha medieval. A intervenção rasgou seu antigo traçado e conectou diferentes pontos da cidade. Esse urbanismo refletiu também na América do Norte. O projeto para a nova capital americana se evidencia principalmente pelos grandes eixos, caracterizando o traçado e a malha urbana. Diferentemente de Paris, a nova capital foi totalmente planejada seguindo este modelo, construindo uma nova identidade e inserindo no contexto local uma nova paisagem.

Os reflexos do urbanismo gemânico, com disciplina técnica e ênfase na estética, podem ser vistos nas intervenções urbanas de Otto Wagner em Viena, que integrou a antiga cidade murada com seu entomo. Embora contestado por Sitte, quanto a sua qualidade estética e despreocupação com os elementos artísticos do traçado da cidade medieval, a 
conectividade foi o principal elemento para criar as interfaces urbanas entre os dois fra gmentos existentes (Fig. 11).
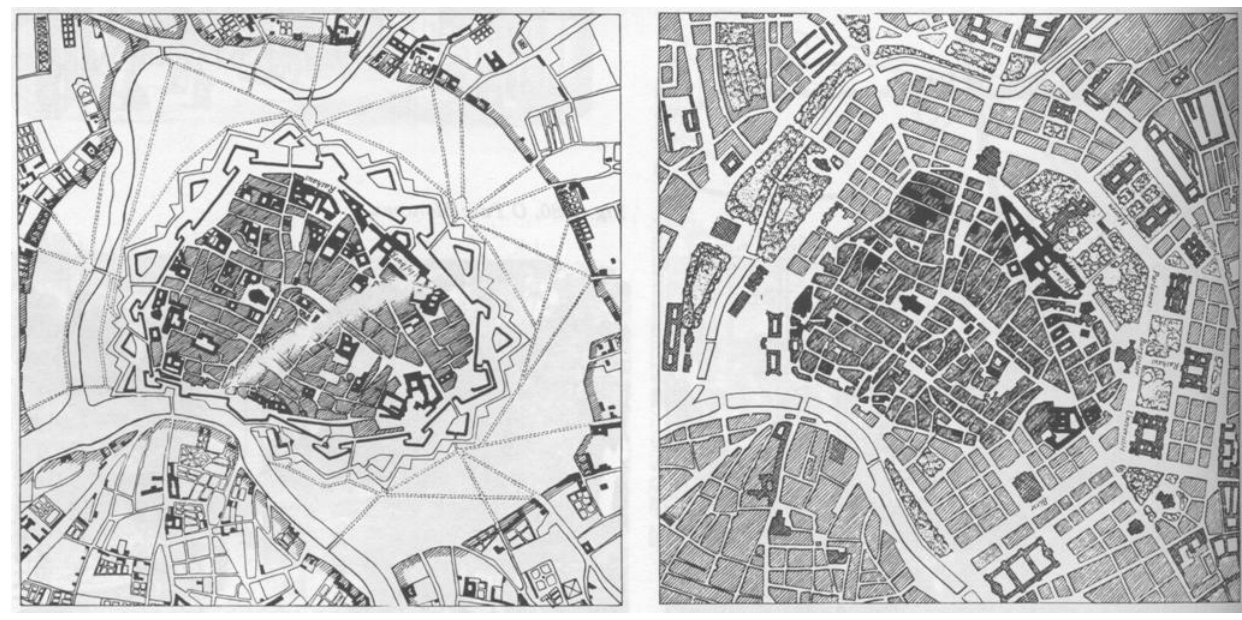

Fig. 11, Viena antes de depois de sua intervenção urbana. (Fonte: BENÉVOLO, 1999)

A cidade modema, embora apresentasse em sua concepção formal, vias de ligação, não se conecta na escala gregária, alterando as relações de contato no espaço urbano. O limite entre conexão e exclusão produziu espa ç os fra gmenta dos nã o só espa cia Imente, ma s so c ia Imente.

Os elementos a serem ligados variam, podendo ser desde grandes áreas de presenvação, como corredores verdes, a pequenos espaços residuais que se unem as outras atividades do urbano. As diferentes fomas de representação e de apropriação, são causadas por um conjunto de fatores que analisadas indicam os principais pontos de atração e de movimentação da sociedade nos locais públicos e edificados de uma cidade. Os efeitos que o ambiente construído causa na população, condicionam a vida nos espaços coletivos, deteminando a intensidade de fluxose a vitalidade de determinadasáreas.

Analisar os movimentos e permanências no espaço remete à relação entre espaço livre e construído que se forma nas cidades. O comportamento da população indica essas interfaces. Todo ambiente é causador de efeitos na sociedade, e através deles são moldados os diferentes ritos que formam alguns condicionantes da prática cotidiana. 
“Do contrário teríamos um mundo onde coisas diferentes, a o terem suspensas as relações diferenciadas e partic ula res com seus efeitos, passariam: 1) a ter efeitos iguais. Elas perderiam seu sentido, e teríamos um mundo onde as diferenças não importariam, porque coisas diferentes teriam os mesmos resultados. Nossa experiência do mundo seria a de um mundo homogêneo, sem 'elementos', sem diferenciação intema. Entretanto, um mundo sem relações de causa-efeito, para desconforto dos 'pós-estruturalistas', seria impossível. 2) ou a ter efeitos a lea tórios - imprevisíveis." (NETTO, 2006)

As diferenças são caracterizadas pela diversidade física e social, funda menta is para o seu caráter de public idade. Os efeitos podem ou não depender do deteminismo de um projeto, ou da própria flexibilidade que este pode proferir. O espaço é moldado a partir da rede de movimentos, que deteminam os comportamentos sociais nas cidades, e a ciência pode revelar essa relação.

O estudo da axialidade urbana ${ }^{17}$ entende a cidade como um sistema de espaços através de seu tecido físico, verificando os diferentes graus de integração da malha urbana. Esta relação é direta, porém nem sempre matemática, e detemina o comportamento dos fluxos na cidade, visto que a estrutura física de um ambiente urbano é complexa por "natureza". As tramas que regem o seu desenvolvimento e a vida da sua população vêm sendo estudadas como um processo de causa e efeito, ajudando a formular bases teóricas e prátic as de como conformar espaços.

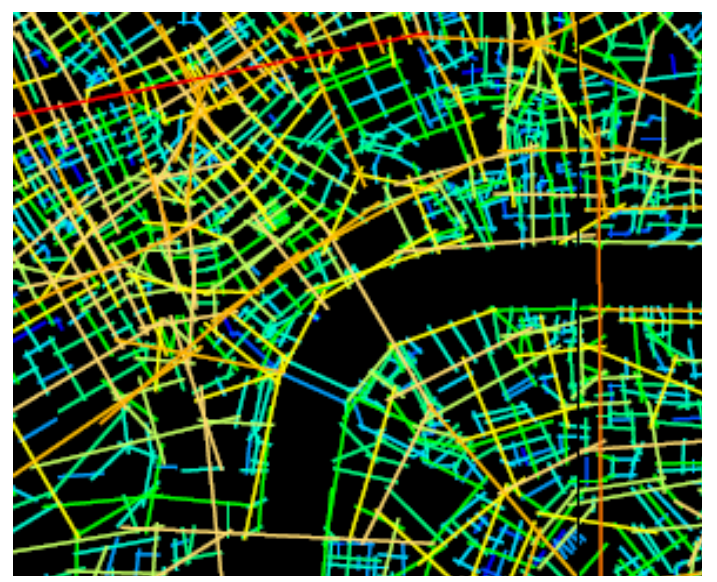

Fig. 12, Estudo da axialida de da trama urba na de Londres. (Fonte: SPACE SYNTAX, 2006)

\footnotetext{
${ }^{17}$ Especificidade da sintaxe espacial que a nalisa o grau de integração do tecido urbano. Os estudos rea lizados utilizando os pressupostos da sintaxe espacial têm como principal centro de pesquisa o laboratório de Sintaxe Espacial com sede na Ingla terra. (HIWER, 2006)
} 
O laboratório de Sintaxe Espacial abriga alguns estudos de Bill Hillier para Londres e outras cidades (Fig. 12). Nas análises efetuadas pelos pesquisadores, uma pergunta sempre inicia os estudos: será que a forma faz diferença na complexidade espacial? Para responder esta pergunta é necessária uma a nálise ampla e sistêmica para estudar os movimentos, uso do solo, desempenho, dados sociais, e outros condicionantes que determinam o uso do espaço livre.

Para Holanda (2007), se há ou não "planejamento" é irrelevante: a forma-espaço da cidade não depende disso mas de valores culturais: são eles que determinam e que explicam a atuação de "planejadores" (especialistas, dentro da divisão social do trabalho) ou "não-planejadores" (não-especia listas, idem), igualmente.

A Sintaxe Espacial é um conjunto de técnicas de decomposição analítica dos espaços que permitem a identificação, quantificação e qualific ação de atributos de unidades espaciais: axialidade, convexidade, conectividade, e principalmente de levantamento de presença, fluxos, ausência e loca lização de encontros.

Fig. 13, Esboço da conec tividade de fluxos para o espaço. (Fonte: SPACE SYNTAX, 2006)

Esta ferramenta começou com a análise da relação entre estrutura e função na arquitetura, sobre os efeitos do ambiente edificado nas pessoas, avaliando a relação entre as fomas e a disposição destes, para verificar qua is ambientes ma is a traiam os usuánios. Este estudo passou para a escala 
urbana, apropriando-se da complexidade existente nesta dimensão, para estudar não só os efeitos da arquitetura sobre os espaços livres, mas da estrutura social que se cria e incide através dos movimentos e permanência no espaço.

Os efeitos desta relação se formatam no espaço, e é a través desta, que se pode verificara síntese que ocorre pelas inúmeras redes invisíveis que se configuram na estrutura física proporcionada pela malha urbana. Este fato demonstra o grau de intensidade entre o real e o abstrato, que dinamiza uma paisagem e gera as variadas redes que estruturam e compõem a dinâmica espacial.

\footnotetext{
"Aqui, a relação a lea tória entre a rquitetura e seus efeitos implic a em suspender a própria possibilidade de uma relação entre forma e função, isto é, que uma forma pode ser mais apropriada que outra para a funcionalidade de uma atividade, pode 'auxiliar' mais ou menos a a tivida de." (NETTO, 2006)
}

A trama urbana é complexa e detentora de situações que proporcionam a concentração ou a dispersão da população no espaço livre. A sua hierarquia remete geralmente a uma condição espacial e de uso que estabelece os caminhos percomidos pela cidade. O objetivo da sintaxe é estimar como a configuração da malha urbana os influencia, e o efeito do ambiente construído sobre os usos do espaço livre.

Segundo Bill Hillier, há duas teorias que direcionam para essa compreensão, a do movimento natural e a do movimento econômico. 0 primeiro ocorre por forças naturais, e se dá pela própria estrutura que configura o espaço de forma homogênea, sem a necessidade de atrativos. A segunda, é a dinâmica central do crescimento das cidades, e combina o movimento natural e a estrutura da grade com os usos da terra e a densidade, em caminhos diversos para diferentes espaços cultura is. Dentro desta diversidade criada pela vida urbana, Hillier afirma, que o espaço necessita de fato sera linguagem comum da cidade.

Assim, é possível compreender e desmistificar o papel do projeto no desenvolvimento urbano, e buscar subsídios para uma nova urbanidade. A 
compreensão de como esses se comportam, pode ser uma possibilidade de produzir e reproduzi-lo através das dinâmic as so cia is que nele se conformam.

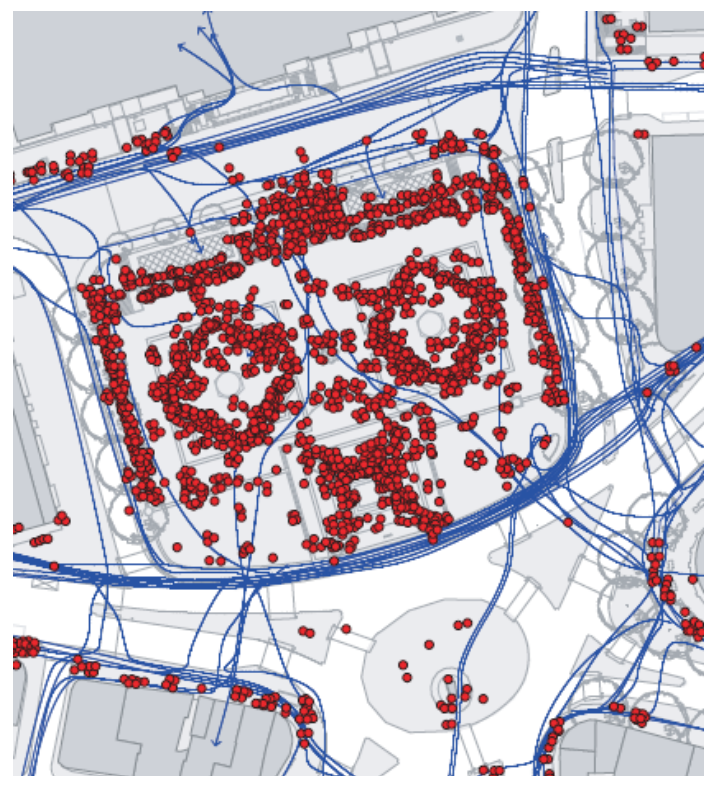

Fig. 14, Fluxose concentração de pessoasna Trafalgar Square, Londres. (Fonte: SPACE SYNTAX, 2006)

Essa ferramenta de estudo tem em Palmas um importante objeto de análise. A cidade planejada se desenvolve entre o determinismo do projeto e as forças cultura is que são praticadas nos seus inúmeros espaços livres. A imposição dos modos de vida e da função pragmática para o uso do solo, entra em contraposição com as necessidades, ou dos movimentos econômicos como afima Hillier, de seus habitantes. As forças econômicas que se configuram em algumas quadras da cidade e nos distritos que se formaram na periferia, moldam as novas faces deste planejamento urbano, seja na paisagem, ou na vivência dos espaços livres, construindo uma cidade real, onde os movimentos e permanências no espaço geram a diversidade de tramas sociais, incorporando outros valores aos convencionados pelo desenho da cidade.

A forma da cidade se divide em espaços construídos e livres, relação está que interfere diretamente na paisa gem. As interfaces existentes entre as duas dimensões caracterizam as interações físicas e sociais que derivam desta relação. Algumas barreiras perduram na relação entre tempo-espaço, 
se apresentando como novas estruturas para deteminar as segrega ções no espaço urbano. Os extensos muros da cidade prejudicam uma interface direta, e faz com que as arquiteturas do construído não tenham uma visibilidade e interação com o espaço público.

No plano piloto de Brasília, diferente de Palmas, há uma rigorosa nomatização edilícia, determinando os limites entre o edifício e o espaço livre nas superquadras. Embora haja uma perda de identidade em meio a tantas quadras parecidas, a escala desta possibilita uma interface direta desta relação. Não é uma defesa do plano de massas de Brasília, tampouco do plano, mas de como o projeto pode ser um instrumento que potencializa diferentes formas de a propriação dos grupos socia is.
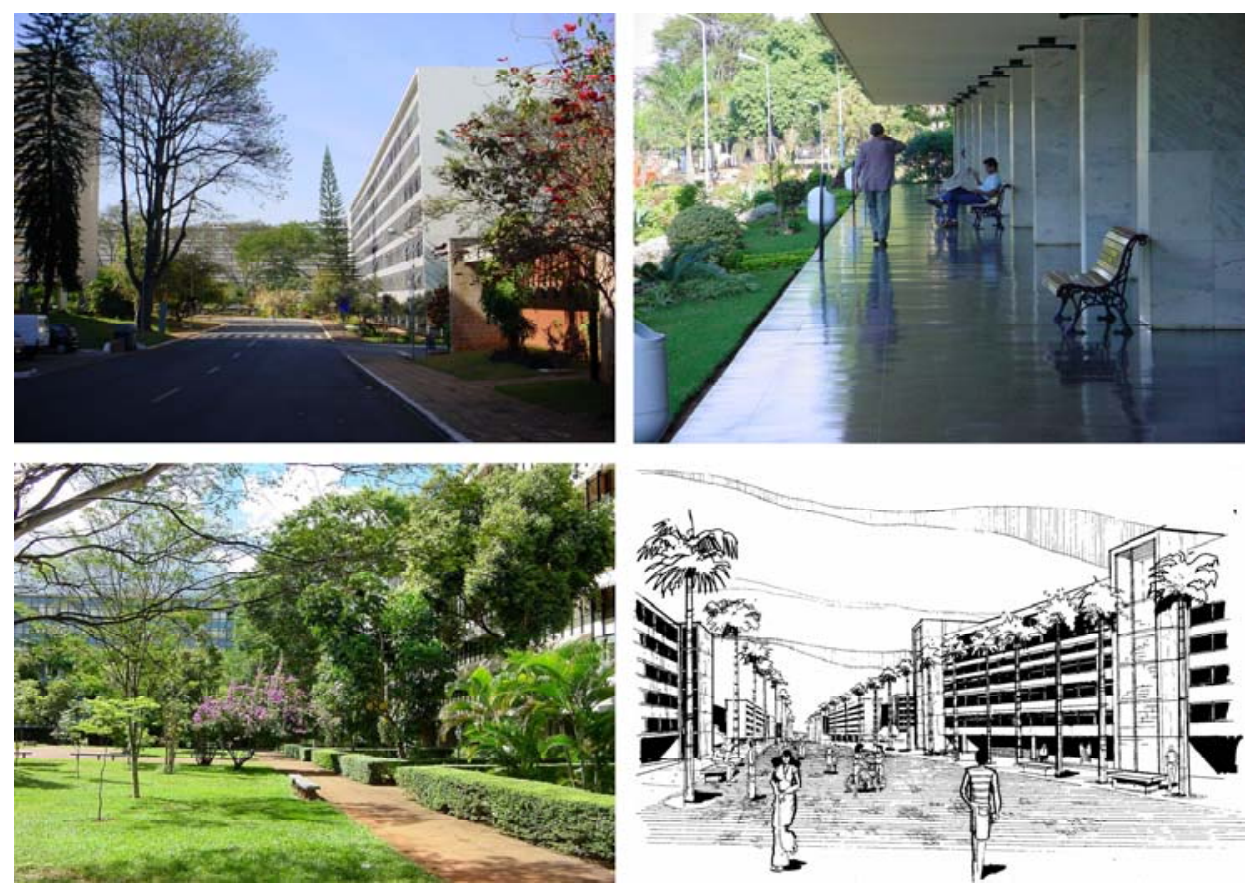

Fig. 15, Relação entre espaço livre e edific ação nas superquadras de Brasília. (Fonte: HOLANDA, 2007)

A redescoberta de praças históricas, medievais, renascentistas, barrocas, como bons exemplos entre espaço livre e arquitetura, revela a importância da relação volumétrica, espacial, de cheios e vazios, e da escala gregária, como a Piazza de Del Campo e Piazza San Pedro. A urbanidade está presente na forma como a edificação se apropria de seu locus, sem propiciarfacescegas ao espaço livre. 

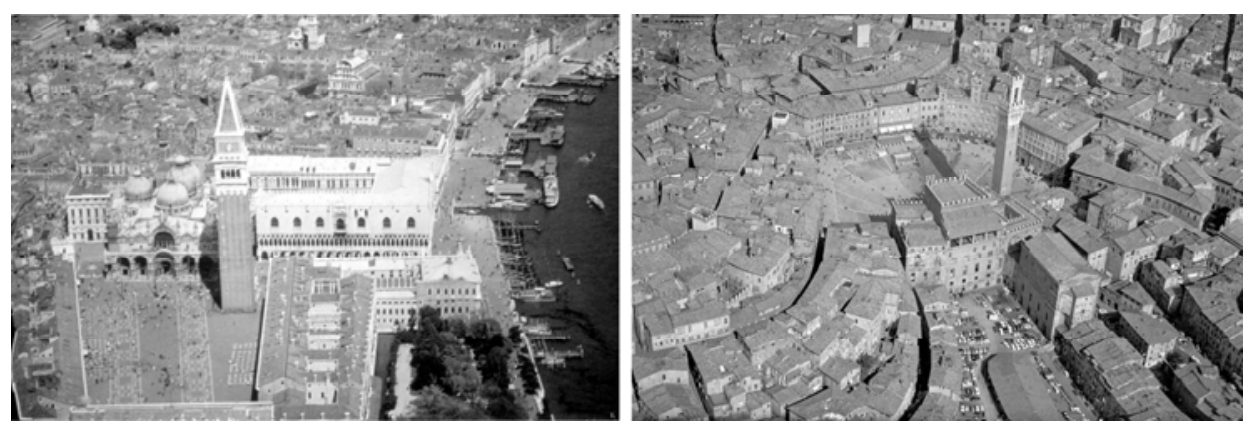

Fig. 16, Piazza San Marco e Piazza del Campo (Fonte: HOLANDA, 2007)

As interfaces físicas e sociais existentes nas cidades qualificam o espaço urbano como o local do encontro e das trocas. Assim como afima Solá-Morales, os lugares da arquitetura atual não podem ser permanências produzidas pela força da firmitas vitruvianas. Essas desilusões não têm o porquê levarà redução de uma arquitetura da negação.

\begin{abstract}
“Assim, no que diz respeito à questão do espaço público, deverá ser considerado essencial o estudo de sua complementaridade com a arquitetura, tendo em conta a necessária congruência entre as c a ractenístic as tipológic as dos ed ifíc ios e as diferentes exigências das várias (e cada vez ma is indistinguíveis) tipologias de espaç os públic os (praça, rua, jardins, parques, largos...). Mais precisamente, tal essencial complementaridade deve ser aprofundada não apenas em termos de objetivos cenográficos ou superficialmente neobarrocos mas sim tendo em conta a continuidade de uso interior/exterior que desde sempre caracterizou a própria essência do espaço públic o." (GIANGREGORIO, 2000, p 05)
\end{abstract}

As dinâmicas que os espaços livres e públicos criam entre si, se caracterizam por um sistema que se confoma na trama urbana de uma cidade, possibilitando diferentes formas de apropriação, conformando lugares e costurando as tramas socia is. Assim como a fima Huet, os espaços públicos não funcionam de modo isolado, eles são sempre parte de um complexo sistema contínuo e hierarquizado. É pela continuidade da rede dos espaços públicos que a cidade vai tomando a sua forma, é pela permanência no tempo dos espaços públicos que a cidade constitui sua memória. (2001, p 148) 

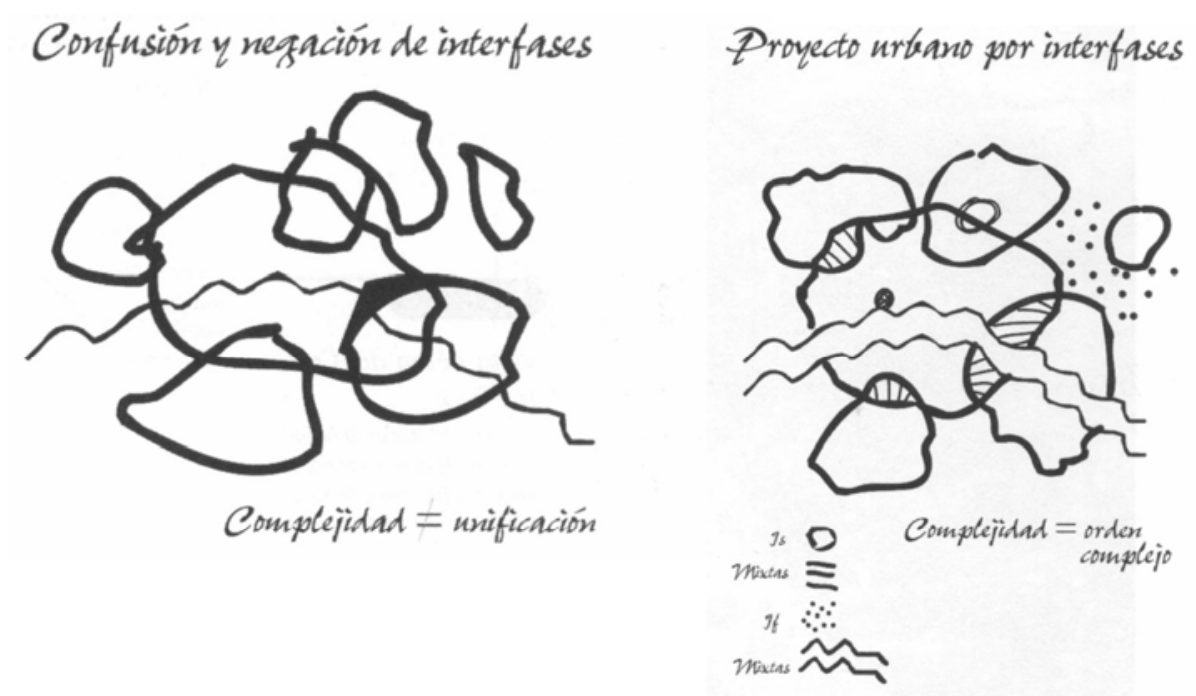

Fig. 17, Modelo que nega as interfaces e modelo urba no com interfaces. (Fonte: PESCI, 1999)

Esse sistema independe de uma intervenção projetual, podendo existir e coexistir em uma malha urbana que cresceu sem planejamento. Porém, como o objetivo deste trabalho é identificar os limites do projeto na conformação de lugares em uma cidade planejada, as redes de espaços livres projetadas apresentam um importante papel na sua condição de urbanidade. A já mencionada intervenção de Sisto $V$ em Roma, criou um sistema que se conectavam por espaços livres, ligando os principa is espaços públicos. A cidade planejada de La Plata na Argentina, projetada por Pedro Benoit, criou um desenho urbano que enfatizava a conectividade dos espaços livres na sua trama.
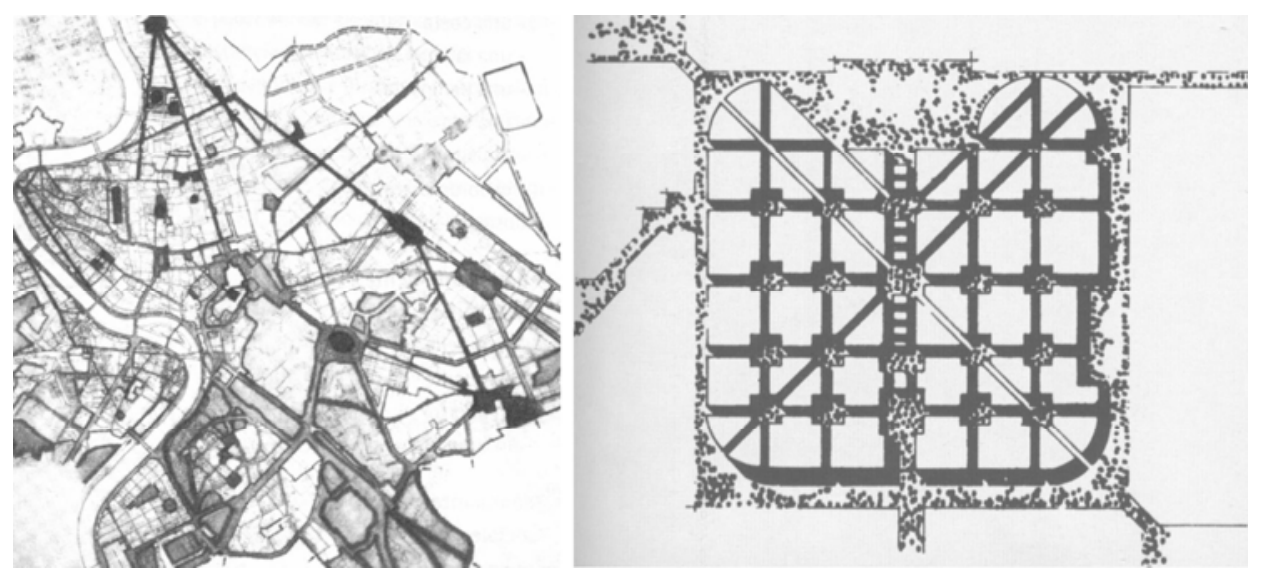

Fig. 18, Sistemas de espaços livres em Roma e na cidade de La Plata. (Fonte: PESCI, 1999) 
O projeto de lldefonso Cerdá, escolhido através de um concurso para a ampliação da malha urbana de Barcelona, teve como principal ponto de estruturação a organização da circulação, através das avenidas que formam o sistema viário e delimitam as quadras que caracterizam o traçado. Essas foram pensadas inicialmente como elementos capazes de abrigar as edificações, que seguiam um padrão urbanístico e edilício, e uma rede de espaços livres que se formariam no interior de cada quadra, conectando-se por toda a cidade. O projeto original foi modificado, alterando o padrão de ocupação e da rede de espaços livrespensadas para a cidade.

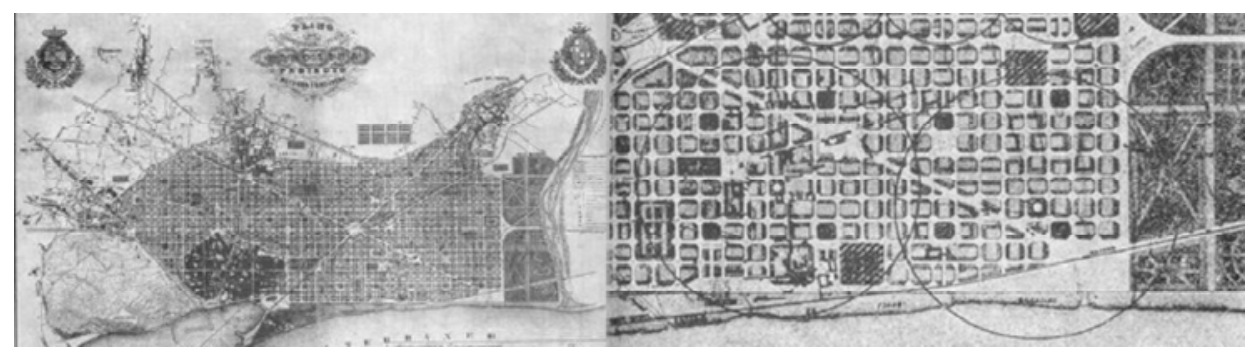

Fig. 19, Plano de Cerda para Barcelona. (Fonte: BENÉVOLO, 1999)

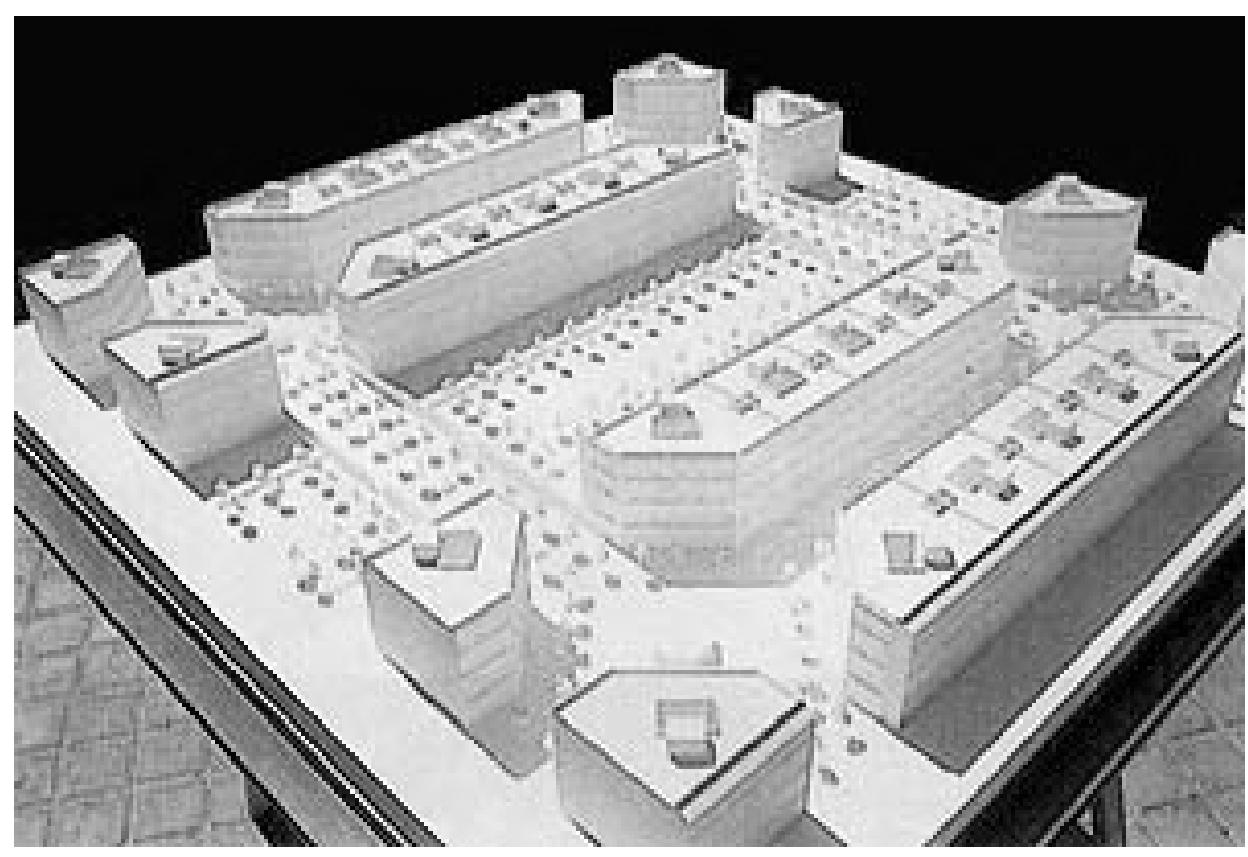

Fig. 20, Maquete de uma quadra de Barcelona com as caracteństic a sorigina is entre espaço livre e construído. (Fonte: VITRUVIUS, 2006)

Esses articulam as estruturas invisíveis e decompõem o espaço em pequenos locus da cidadania e do convívio coletivo. Sistemas referem-se à 
conectividade e principalmente a articulação, e podem apresentar interfaces direta ou indireta com outros sistemas da cidade, como o dos espaços construídos. O projeto de Cerdá apresentava uma interface entre as duas dimensões.

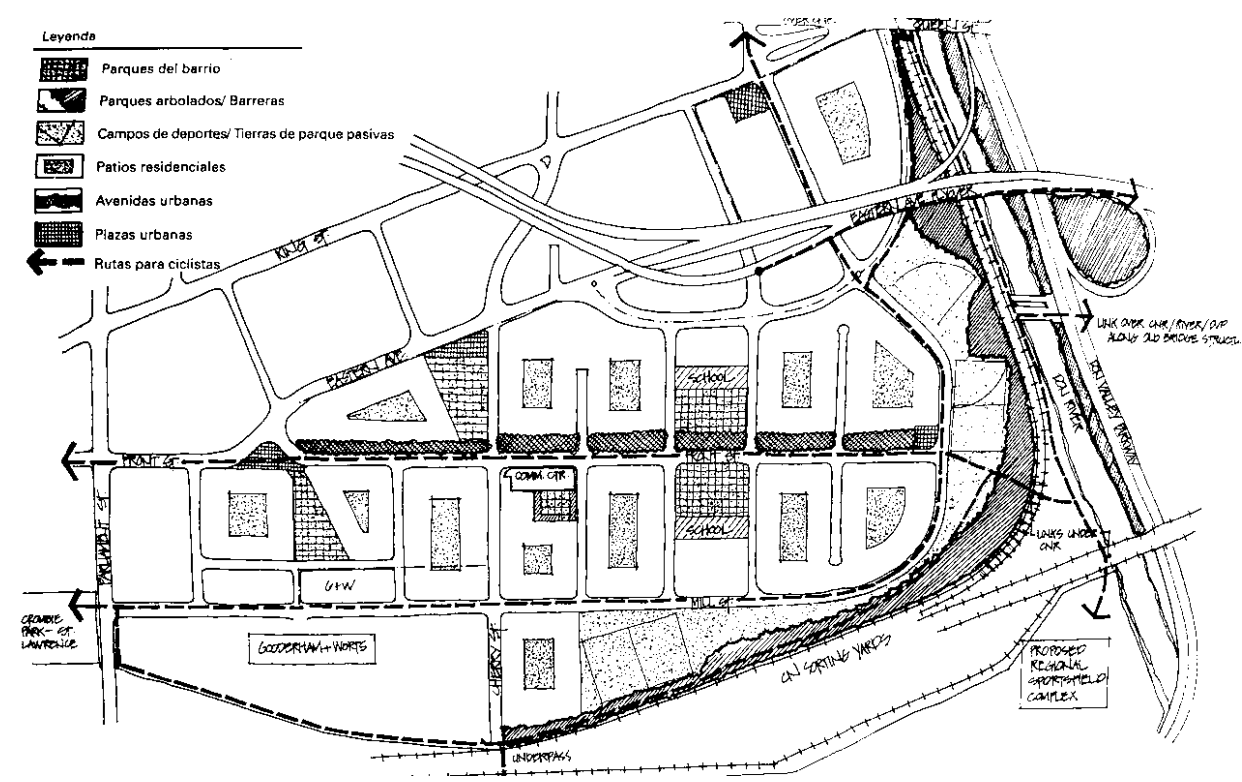

Fig. 21, Sistema de Espaços livres em um projeto de uso urbano de uso misto em Toronto: diversida de de usos do espaço livre. (Fonte: HOUG H, 1995)

Os espaços verdes representam um importante coeficiente desse sistema. Estes se caracterizam por áreas permeáveis e livres de edificação, onde a vegetação é seu principal elemento. Em Palmas, muitos se encontram em áreas privadas, a inda não ocupadas, e atualmente denotam uma outra característica ao sistema.

O projeto urbano deve não somente deteminar as diferentes articulações, entre público e privado, entre livre e edificado, mas entender que estas se originam através das tramas sociais. Projeto e apropriação representam os limites entre o deteminismo e as dimensões culturais e políticas que o conformam, inscrevendo espaços identitários e relaciona is. Em Palmas, esta relação caracteriza diferentes tipos de lugares em meio à cidade ainda em formação, ora condicionadas às diretrizes do projeto ora as contrapondo, criando um sistema de espaços que indicam seus limites na constituição da urbanidade. 


\section{Doconceito a contexto}

Na recente história urbanística, Palmas, a última cidade brasileira planejada do século XX, se depara na atualidade com questões e conflitos que mesmo o planejamento urbano não conseguiu evitar. Situada no "coração" do Brasil, onde o desenvolvimento se espalha e cidades crescem formatando uma imagem de progresso em meio ao cerrado brasileiro, ela se insere em uma paisagem singular, dominando o imaginário dos moradores da região com sua modemidade, em um contexto geográfico identificado como uma unidade ecossistêmica de grande valor ambiental e econômico.

Parte deste valor se dá pelo grande potencial agrário e hidrelétrico da região, onde o relevo adequado a diferentes atividades e o solo fértil com abundância de água, gera investimentos maciços de empresas privadas e uma estratégia govemamental de ocupação do teritónio brasileiro para o interior do país. Essa teve origem no ciclo do ouro, seguida pela expansão agrária, intensificada na metade do séc. XX pela criação de Brasília, que gerou um surto populacional e urbanístico decisivo para o desenvolvimento da região, resultando no crescimento de inúmeras cidades e na criação de outras, planejadas ou espontâneas.

Palmas se insere na continuidade deste contexto. A mais nova capital de um estado brasileiro, o Tocantins, criado na Constituição de 1988, dividiu a área do estado de Goiás ao meio, deixando o norte, região menos desenvolvida, para a criação de um estado que pudesse representar a esperança de uma população marcada por inúmeros conflitos sociais, e pela ausência de ações govemamentais e de iniciativas privadas capazes de mudaro panorama de esquecimento em relação ao restante do país. A criação do Estado e da nova capital, trouxe não só para a população local, mas como para milhares de brasileiros, a esperança de conquista onde, assim como Brasília, o cerrado é novamente palco e agente do desenvolvimento, gerando uma modificação irreversível quanto à transformação e ocupação desta paisagem. 


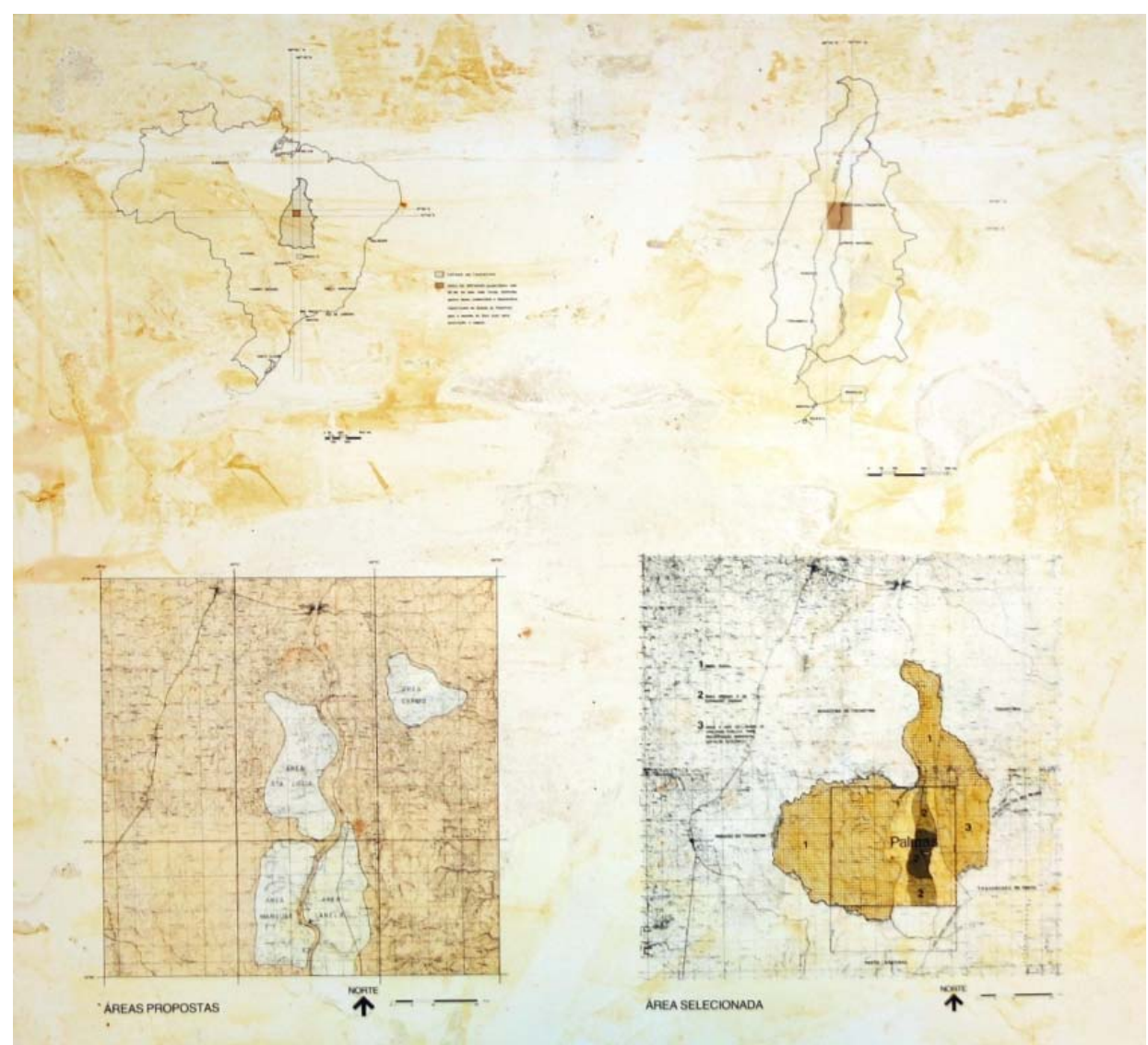

Fig. 22, Mapa da localização do Esta do do Tocantinse da cidade de Palmas. No canto inferior esquerdo, as quatro áreaselencadas para a implantação da capital e a o la do a área esc olhida. (Fonte: SEMUC, 2006)

A localização geográfica da cidade, entre o rio Tocantins e a Serra do Lajeado, foi escolhida pela sua paisagem natural e pelo sítio geográfico. Walfredo Antunes, co-autor do projeto e sócio do escritónio GRUPO 418, afima que o partido e conceito idealizavam a criação de uma cidade integrada a os elementos da paisagem, objetivando a conformação de uma identidade e uma integração entre os elementos que constituem o meio natural e o antrópico.

\begin{abstract}
“Uma paisagem construída pelo homem compreende a reunião de objetos pertencentes a várias escalas de apreensão, objetos que tanto revelam os signific ados inerentes a vida cotidiana dos lugares, quanto comportam-se como pontos foca is que enfatizam a intenção a glutinadora na construção do temitório, na transformação cultural da natureza da paisagem." (LEITE, 1998, p 66)
\end{abstract}

\footnotetext{
18 Escritório de arquitetura com sede em Goiânia, os sócios Luis Femando Cruvinel Teixeira e Wa lfredo Antunes de Oliveira Filho foram os responsáveis pelo plano da Cidade de Palmas.
} 
A implantação respeitou esses condicionantes, adequando a cidade aos limites natura is e ao mesmo tempo referenciando-os como pontos visuais. Em qualquer parte da cidade se pode observar a Serra do Lajeado margeando a face nascente, enquanto que pelas Avenidas Leste-Oeste é possível observar em perspectiva o lago que se encontra no poente de Palmas.

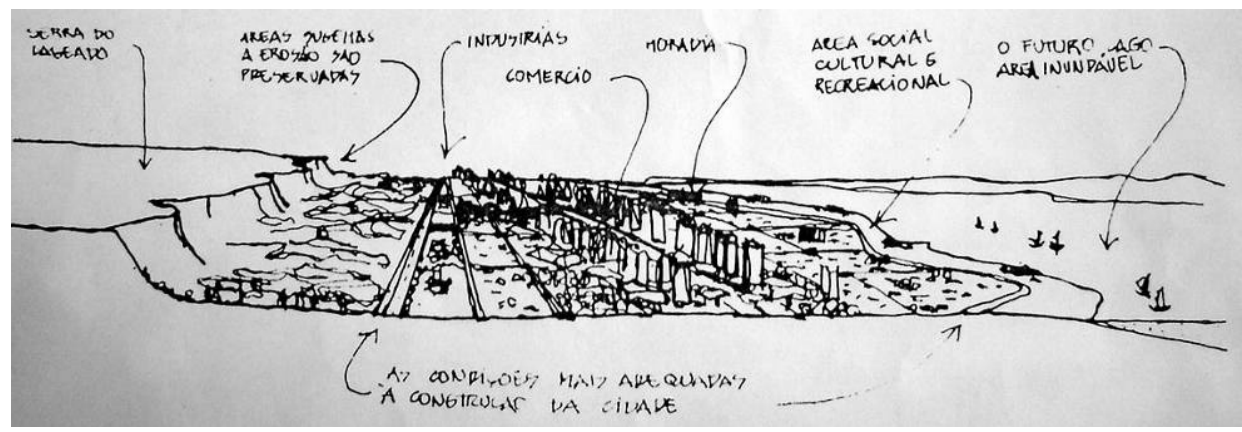

Fig. 23, Loc a liza ção da cidade entre a Serra e o futuro Lago, a tua Imente já constituído.

(Fonte: REVISTA PROJ ETO $n^{\circ} 146,1991$ )

Neste ponto, o plano se conecta com o contexto natural, permitindo aos seus habitantes participar como agentes e espectadores ao mesmo tempo desta relação. A construção do lago foi um processo antrópico que permitiu aos moradores observar como a ação humana modifica bruscamente a paisagem e o cotidiano de uma cidade. $O$ rio que estava distante agora é próximo, e participante de um ambiente urbano inserido visua Imente e fisic amente nos seus limites. Mesmo ocorrendo essa integração com a paisagem na escala do plano diretor, quando se remete a escala urbana e a verificação das premissas iniciais, verifica-se uma ruptura preocupante entre os espaços livres da cidade e a paisagem do cerrado.

É comum ver manifestações apaixonadas em defesa do Cerrado assim como é feito pela mata Atlântica, Pantanal, Floresta Amazônica e até da Caatinga. O que se vê, porém, são focos desconexos de discussão do real valor deste ecossistema para o equilíbrio ambiental e econômico brasileiro, sob o ponto de vista de gestores, pesquisadores e principalmente de seus moradores. Para os planejadores da cidade, ela estaria inserida no contexto geográfico, a rraigada na manutenção dos principais elementos 
organizadores desta paisagem, ponto crucial para a plena consolidação do contexto urbano.

\begin{abstract}
"Os vapores das nascentes da sinuosa Serra do Lajeado e do curso do Tocantins se fundem em nuvens, de cuja integração de energia positiva, emanada das águas correntes, com a massa calma do plano de água da futura represa do Lajeado sobressaem os terrenos da cidade. Nestes espaços, integrados com a natureza através de um traçado simples e lógico, os habitantes devem viver e conviver em ha monia consigo mesmo, com a comunidade e a natureza. Esta consciência social e ecológica deve refletir-se em ruas tranqüilas e praças arborizadas. O homem conviverá assim, em hamonia com a cidade, respeitando a natureza e os outros cidadãos." (PLANO BÁSIC O/MEMÓRIA - GRUPO QUATRO, 1989, p 02)
\end{abstract}

Tratar de temas ligados à questão da paisagem implica necessariamente lidar com a consciência ambiental de cada indivíduo e dos diferentes grupos sociais. A fomação multi-cultural da cidade criou variadas fomas de apropriação do espaço, e diferentes pensamentos quanto à inserção da vegetação nativa como elemento desta nova paisagem. Para Joan Nassauer, a saúde da paisagem requer que humanos apreciem e tomem cuidado dela. (1997, p 69)

Se para os planejadores, a relação entre espaço urbano e natural reforça o conceito do projeto, para os gestores que a seguiram construindo, esta foi uma oportunidade para produzir uma imagem ecológica que a cidade necessitava para atrair moradores e investidores. A criação do slogan, Capital Ecológica19, para denominar a qualidade ambiental da cidade reforça este pensamento. Para a atual estrutura e tamanho da cidade, os espaços verdes são lugares do conflito entre gestão e apropriação, entre identidade do cerrado e novas importadas de outras regiões do Brasil.

\footnotetext{
19 Titulo concedido pela prefeitura em virtude da grande quantidade de área verde per capita na cidade, e pela possibilida de de implementação do programa de seqüestro de carbono, o que atrairia investimentos para cidade.
} 


\section{A gênese do urbanismo de PaImas}

O projeto para Palmas não escapou da gênese modemista de concepção de cidades. Este julgamento é discordante da afimação dos a utores do projeto que a classificam como contemporânea, porém, em uma análise do plano, percebe-se a influência de traços e de parâmetros que advém do movimento modemo.

O traçado ortogonal, mesmo sendo uma técnica historicamente utilizada, se coloca como o principal articulador da circulação e da distribuição das grandes quadras, inscrevendo uma forte marca no temitório praticamente intocado do cerrado brasileiro. O desenho delimita uma nova paisa gem, criando novos horizontes de uma cidade que ainda estava por se formar. Se como afima Casey, que arquitetura é uma escrita do espaço, um modo do espaçamento na qual produz um lugar para o evento, a criação de lugares em uma nova cidade é papel de sua forma física, objeto, e das açõesque dela se apropriam.

Uma semelhança com o plano urbanístico de Chandigarh revela que a cidade apresenta uma forte influência do deteminismo e tecnicismo que se imaginava ser o principal formulador de espaçosideais. Pa ra Solá-Morales (1995), a noção de espaço com uma categoria própria da arquitetura é uma noção modema. A tentativa de criar espaços ordenados, seguindo funções, faz de Palmas um resquício de modemidade de algumas cidades no interior do Brasil, mastendo em Brasília seu principal referencial.
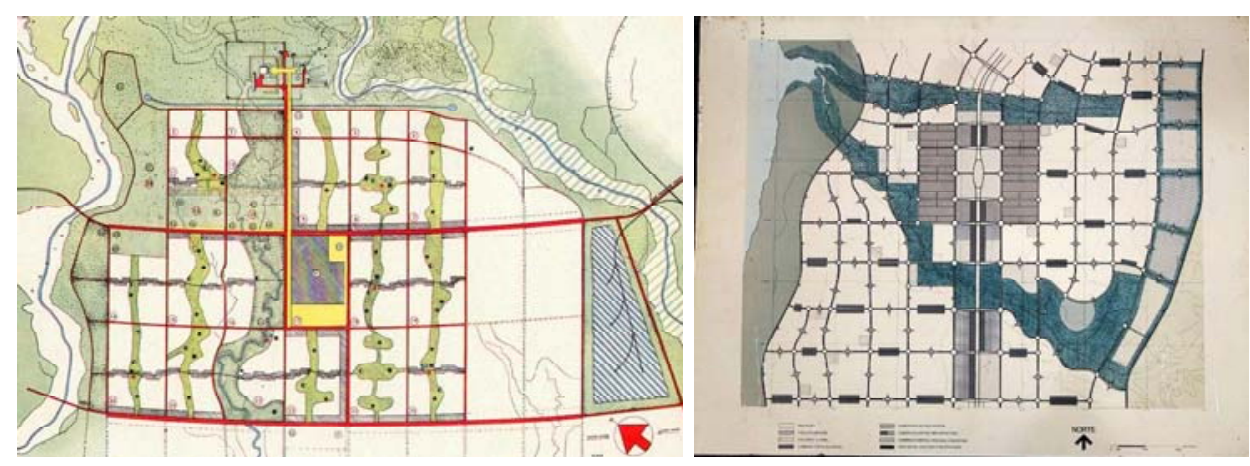

Fig. 24, Plano de Chandigarh e de Palmas: a similaridade do traçado marcando o teritónio denota uma forte influencia do modemismo. (Fonte: BARCELOS, 2001; SEMUC, 2006) 
A necessidade de projetar uma nova capital em pouco tempo, fez o processo projetual reunir alguns modelos consagrados, e criticados, do planejamento urbano, e aplicá-los no sítio geográfico. A malha que divide a cidade em grandes quadras, ordenou as funções urbanas: residenciais, comerciais, de serviços, industria is, limitadas pelo sistema viánio. A c irculação expressa seria o principal meio de locomoção pelas avenidas, deixando o trânsito local e de pedestres para dentro das quadras. A necessidade de respeitar os novos paradigmas ambientais e a legislação fez surgir diversas áreas de preservação, principalmente nos fundos de vales e em áreas de interesse ambiental.

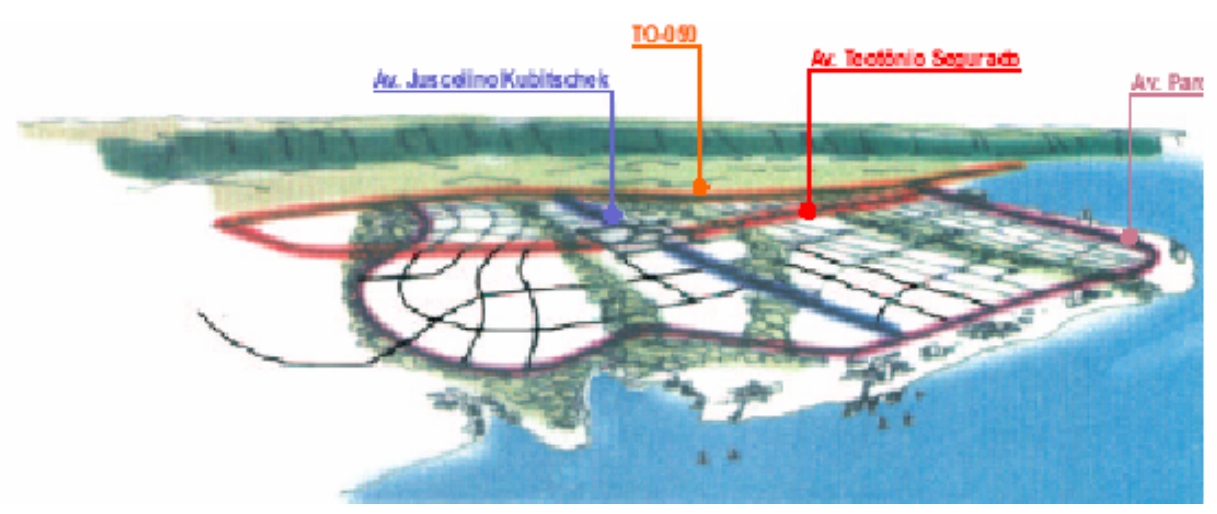

Fig. 25, Perspectiva geral do plano de Palmas. (Fonte: IPUP, 2002)

O fato de projetar uma cidade é uma oportunidade lotérica que poucos arquitetose urbanistas conseguem ao longo de uma vida profissional dedicada às questões urbanas. O fato de não ter sido um concurso público gerou um levante da categoria profissional, em vão, o projeto fora contratado. Com a escolha do local, que passara por um levantamento técnico para a sua melhor localização, iniciaram-se os primeiros esboços para a capital, que tomariam a forma atual seguindo os limites físicos da paisagem.

As linhas das avenidas se encarregaram de delimitar uma nova paisagem e confomar a escala monumental da cidade. Cada avenida definiu quadrantes de 700 por 600 metros em média, resultando nas áreas das unidades de vizinhança, e dentre elas, as quadras que hoje são 
conhecidas como Vila União. Cada uma das unidades fomou a base para a consolidação urbana da cidade, onde individualmente deveriam ser células capazes de proporcionar às necessidades de moradias, de comércio, de lazer, de educação e de espinitualidade.

A gênese tecnicista do planejamento não conseguiu se desvencilhar da ditadura do definido pelo arquiteto. A incorporação do modelo de unidade de vizinhança de Perry e Stein, divulgados principalmente pelo RPAA, e que serviu como base para a utopia do espaço ideal modemista, seguiu os conceitos de limites, escala, áreas institucionais, sistema intemo de ruas, moradia, comércio e principalmente de áreas públicas, ca racterizando uma intenção determinista de ordenamento do espaço urbano.
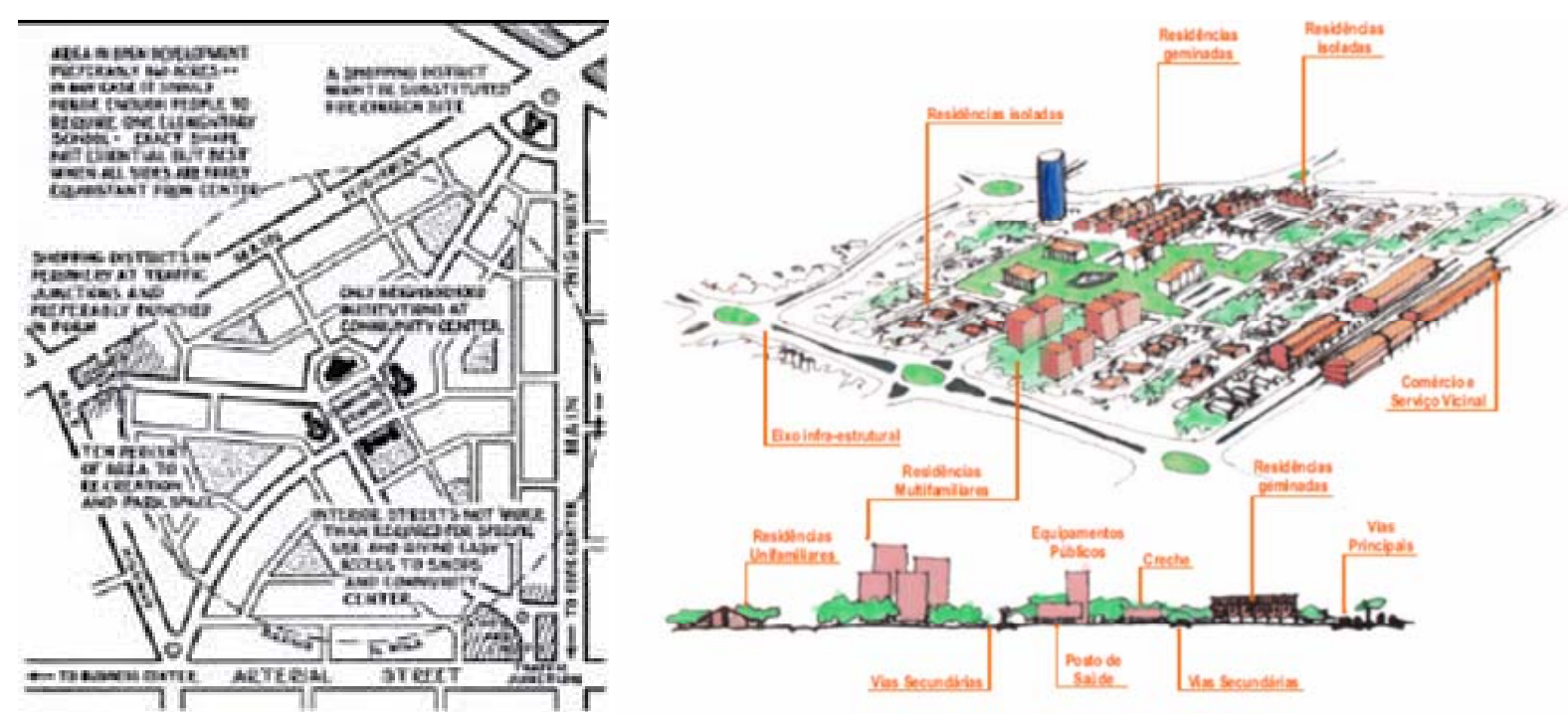

Fig. 26, Modelo de Unidade de Vizinhança de Pemy e de Palmas. (Fonte: BARCELOS, 2001; IPUP, 2002)

O plano parecia seguir uma ordem correta para implantação da cidade, levantamentos, discussão, concepção, elaboração do projeto e das diretrizes. Porém, com a colocação da pedra fundamental, que marcou o início da construção da cidade, começava a separação entre o plano e a cidade real. Uma cidade não se funda, ela se constrói. 


\section{Os Lugares antes e depois da ponte}

Algumas inscrições no espaço de Palmas confrontam com o determinismo do plano, formando e criando novos lugares nos limites entre o projeto da cidade e as práticas culturais de apropriação. É sobre alguns destes lugares que o trabalho enfatiza. Se um temo pode ser adotado para definir a formação da urbanidade em Palmas este é limite, mas não no sentido de barreira, de separação, de contido, de fim, mas de começo, de interface, de potencialidade. A dualidade do temo aparece desde a opção pela área da ocupação, pelas bordas natura is da cidade, passando pelas memórias que existiam no local e às criadas para tentar fomar uma identidade, a té a rápida transformação que o espaço sofreu conectando-se a outros lugares. Estas conexões são pontes que definem novos lugares na paisagem. Para Heidegger, o lugar não está presente antes da ponte...não é a ponte que vem primeiro a estar em um lugar, se não que pela ponte mesmo, e só por ela, surge um lugar. (1994, p 135)

Os limites definiram não só o traçado, mas também o processo de construção da cidade. A expectativa da cidade ideal do plano se deparou com os limites políticos e econômicos que definiram uma nova territorialidade. A segregação manipulada pelo estado fragmentou ainda mais as unidades do plano, iniciando um processo de reivindicação identitária e plural para construção de espaços com novos significa dos.

A contraposição ao projeto se deu em diferentes âmbitos, principalmente nas quadras onde a dimensão política da urbanização se fez com maior intensidade, e isto incidiu diretamente na esfera pública da vida destes locais. As novas inscrições do espaço determinaram um urbanismo marcado por novas conexões e centralidades, gerando novos fluxos e movimentos, e constituindo pontos focais em meio ao desenho urbano original. Estes são resultados das práticas do cotidiano, dos ritos de uma sociedade em formação, que imprimiu suas marcas em meio ao desenho impositivo de organização espacial. As conexões dos lugares se fizeram principalmente entre os espaços públicos da cidade. Para Rabotnikof, falar 
de um espaço público parece necessariamente fazer referência a um lugar, a uma localização, a relações com outros lugares, sistemas ou fluxos comunicativos. (1995, p 02)

A gênese modema que a influenciou, negligenciou toda uma esfera cultural que ina a tuar no espaço urba no. Estas dimensões cria ram o que hoje é uma cidade com caractenísticas e problemas de cidade tradicional, deixando rastros de espontaneidade em meio ao planejado, criando algo inusitado pelo curto tempo da cidade. É o conflito entre o tecnicismo e as forças cultura is.

A conformação de lugares em uma cidade planejada é uma forma de proporcionar um maior reconhecimento de deteminados grupos, e como afirma Rabotnikof, de maior visibilidade das suas ações e das práticas sociais. Em Palmas, a liberdade de traçado intemo das quadras, uma das diretrizes do plano, se apoiou em uma legislação específica de coeficientes comuns às unidades de vizinhanças, para produzir inúmeros modelos de parcelamento, imprimindo uma diversidade de traçados e formas, onde a criatividade de cada projetista direcionava o modelo espacial.

A idéia do projeto como o elemento produtor de lugares esbarra no grande desafio dos arquitetos que é produzir uma esfera pública para as atividades socia is em uma cidade. Seria isso possível? Uma nova dimensão da paisagem em Palmas surgiu entre o espaço determinista e o lugar das prátic as sociais.

\section{Espaço e paisagem em PaImas}

As ciências sociais e aplicadas, como campo de estudo, vêm analisando a relação entre espaço e paisagem, permitindo aos pesquisadores criar novos atributos para o conhecimento do tema, com subsídios essencia is para questionar a atuação do arquiteto sobre o meio natural e como a prática projetual se insere nestes limites. 
Abordar o tema paisagem na cidade de Palmas é ir a seu ponto de partida, ao conceito do projeto como um todo, aos esboços iniciais, a organização espacial, a onientação, dentro de uma pequena parcela de cerrado. A cidade é resultado da apreensão deste fragmento da paisagem do cerrado brasileiro.

\footnotetext{
“Nestes espaços, integrados com a natureza através de um traçado simples e lógico, os habitantes devem viver e conviver em harmonia consigo mesmo, com a comunidade e com a natureza. Esta consciência social e ecológica deve refletir-se em ruas tranqüilas e praças a rboriza das." (MEMORIAL BÁSICO, 1989)
}

A paisagem de Palmas é marcante, desconhecida por muitos e tocante na visão de quem a conhece. A nova imagem desta é a do traçado que rasga a mata, resultado da trama que se adequou à sua geografia física e que cobre o temitónio. Ao mesmo tempo em que depende desta, renega culturalmente a sua história e elimina alguns traços de sua memória natural. Construir paisagens significa sobrepor estruturas, condic ionando às novas necessidades do homem.

Se para Milton Santos a paisagem é o resultado de uma acumulação de tempos, a de Palmas pode se caracterizar pelas distintas etapas, antes de sua construção: natural; do projeto: ideal; e de sua conformação: real. A forma da cidade fez com que esta acumulasse outros elementos para definir sua memória, principalmente os símbolos de sua construção: avenidas, palácios e praças, todos definidos pelo traçado, que se perpetuam como herança de um momento que modificou a paisagem e a estrutura natural do cerrado. Uma paisagem é uma escrita sobre a outra, é um conjunto de objetos que tem idades diferentes, é uma herança de muitos diferentes momentos. (SANTOS, 1991, p 65)

Os impactos causados pela consolidação de sua área urbana são conflitantes quando analisados através do discurso e da prática. Os danos da acumulação antrópica e da transfomação da natureza primeira em segunda são inevitáveis, mesmo sendo uma cidade planejada. Onde a transformação do cerrado foi mais intensa, os espaços se configuraram 
distanciando-se dos valores cultura is existentes no ecossistema. O espaço é um sistema de valores e a paisagem, um sistema de objetos. Mas os objetos, em si, não têm valor: o seu valor é dado por ações que determinam e confimam sua existência. (LFITE, 2004, p 53)

Esses adquiriram novos valores, novos imaginários construídos com a inserção de elementos de outras paisagens culturais. Estes, impostos pela ação antrópica, formataram uma nova visibilidade urbana. As avenidas rasgadas na paisagem são hoje os novos valores que se construíram com a transformação da paisagem, dando a noção exata, não do projeto urbano em sua totalidade, mas da sua relevância quanto espaço da representação de uma nova sociedade.

Nos diferentes lugares de Palmas, as práticas coletivas se abastecem de elementos antrópicos e naturais para configurar os novos espaços que completam o sentido ma is amplo desta paisagem. A proposição do plano, que previa uma perfeita harmonia desta relação, entre espaço e morador, gerou conflitos. Como resultado, as forças culturais deteminaram os fragmentos desta paisagem, conferindo a ela uma legibilidade espacial, independente da proposição determinista do projeto. Assim como afima Leite, são nestes espaços que a visibilidade da paisagem permite a visibilidade das prátic as socia is (1992, p 70).

Os limites do projeto de Palmas expõem as fragilidades e potencialidades da paisagem do cerrado, demonstrando os diferentes condicionantes do ambiente urbano, devendo ser a nalisa dos dentro de uma esfera pública própria para a a rquitetura paisa gística brasileira.

\section{Do plano a cidade real: os limites do projeto u rb a no}

A dua lidade entre urbanismo e urbanização proporcionou um caráter híbrido à cidade, misto de determinado e espontâneo, se conformando nos limites entre o projeto urbano e apropriação. Este urbanismo híbrido, de 
diferentes graus de espontaneidade, produziu lugares em meio às inscrições do desenho no seu espaço geográfico, constituindo a paisagem desta nova capital. Este é fruto das a tuações do Estado: principal especula dor da terra; da diversidade de grupos sociais que constituíram a população; e do imaginá rio coletivo de construir uma nova modemidade.

A legitimidade do plano é exposta a novas formas de apropriação do espaço, criando diferentes graus de flexibiliza ção do estipula do, conduzindo a constituição de locais com variadas legibilidades. Os códigos de postura das construções e de uso do solo, também sofreram diversos níveis de flexibilização, incidindo diretamente na ambiência urbana e na qualidade do espaço construído.

A urbanidade de Palmas se depara com espaços onde a qualidade urbana se insere no limite entre o projetado e o espontâneo, do determinado e do acaso com que alguns lugares parecem se conformar. A cidade utópica, mesmo com os autores não afimando esta pretensão, esteve presente nos desenhos, nas premissas de ordenamento e principalmente no tra tado urba nístic o proposto.

A cidade planejada deveria simular uma condição ideal, onde as funções, a circulação, as articulações e a interações deveriam ocorrer para uma melhor habitabilidade. Mas como alinhar uma cidade ideal com uma cidade real? No caso de Palmas esse limite começa a mostrar algumas escritas no espaço, dando pista de como produzir lugares em meio a essa situação. Se o plano queria enfatizar alguns aspectos não deteministas, e nesta questão seus autores reafimam a principal diferença com Brasília, a combinação de espaço planejado com ares de cidade tradicional, demonstra a visão contemporânea proposta para a cidade, porém, sem perder a mística modemista do traçado viário como principal a rticulador.

\footnotetext{
“Um outro conceito que nós não quisemos ter - como em Brasília e em muitas partes do mundo - foi a de planos de massa. Um conc eito com o qual você dá uma forma quase arquitetônica para a cidade, encara-a como um artefato construído." (REVISTA PROJETO №. 146, 1991, p. 105).
} 
O a rquiteto Oscar Niemeyer, ao conhecer o projeto da cidade e verificar que não haveria um plano de massas mais rígido para as edificações, afimou aos autores que esta cidade poderia virar uma "Esculhambação". Tal frase pode conter certo exagero, mas refere-se justamente a normatização proposta em Braślia que eles quiseram evitar por achar restritivo a uma foma espontânea de construção da paisagem. Porém, o que se observa na cidade é uma arquitetura de má qualidade e conflitos entre espaços do determinado e do vivido.

\begin{abstract}
“Fomos disc utir isso com o Oscar Niemeyer, expliquei isso a ele (não havia o gabarito nas construções de Palmas, isto é, não há controle na altura das construções) e ele falou: 'Luiz Femando, você está louco, você tem que gabaritar essa cidade, senão vai virar uma esculha mbação..., (e virou, o desnível das construções em Palmas é uma coisa de espantar)." (REVISTA PROJ ETO, 1990, no. 146, p. 106).
\end{abstract}

Se o objetivo de um planejamento é o ordenamento, no caso de uma nova cidade este tem um papel decisivo na sua forma de ocupação. O crescimento controlado de Palmas ficou impossibilitado à medida que o Estado, modific ou a dinâmica de crescimento.

O professor do curso de geografia da UFT, Eliseu Ribeiro Lira, que dissertou sobre Palmas em mestrado pela UNESP de Presidente Prudente - A gênese de Palmas - Tocantins (1995), a nalisa quatro fatores que moldaram o espaço geográfico da cidade e interferiram no desenvolvimento do plano original: a propriedade da terra; o processo de incorporação imobiliária; a indústria de construção civil (materia is e obras); e o capital financeiro.

O desordenamento de uma "cidade planejada", interferiu na demanda de infra-estrutura necessánia para abranger uma área maior do que a prevista pelo plano. Mas o erro foi do projeto? Talvez a "Esculhambação" profetizada por Niemeyer não fora somente culpa deste, que se cercou de todos os artifícios técnicos e conceitua is para se concretizar, mas da incapacidade dos gestores em seguir metas definidas por especialistas e adaptá-las às novas dimensões sócio-espacia is. 
O ensaio dos problemas de Palmas ocorreu em Brasília, onde o engessamento do Plano Diretor, tomando-o um patrimônio da humanidade, gerou uma dúvida em como projetar uma cidade. A tentativa de transformar o espaço mais semelhante à de uma cidade tradicional, ao invés de configurá-lo como um modelo arquitetônico e fomal, contrapôs à padronização e à racionalidade do plano de Brasília. Os edifícios com pilotis das superquadras, que permitem uma dinâmica espacial e pública mais intensa, foram substituídos por lotes priva dos, divididos em pequena s qua dras intemas. Ruas locais foram criadas para que realmente existissem bairros tradic iona is nas unid a des de vizinhança.

Para seus gestores, a cidade nasceu para trazer a modemidade a um estado recém criado e carente em símbolos de desenvolvimento. Abrir avenidas, construir palácios e enfatizar a escala monumental, foram mais importantes do que gerar condições de criar uma escala gregária no espaço. Lugar e espaço monumental, são condições muitas vezes antagônicas. O projeto, do ponto de vista de seus autores, priorizou o modo de circulação e teve como preocupação a consolidação de diferentes categorias de espaços livres. Segundo Walfredo Antunes, quatro categorias a definem na cidade.

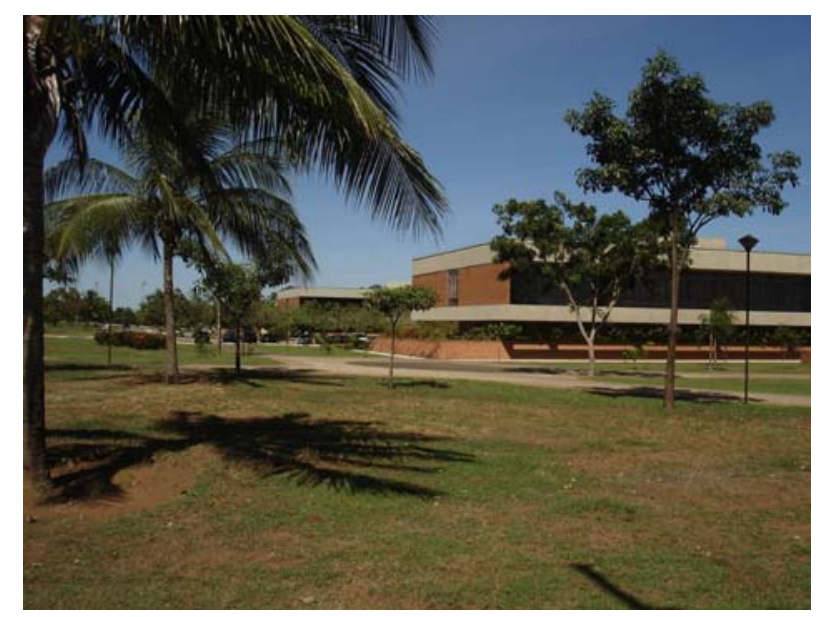

Fig. 27, Praça dos Girassóis: marco iconográfic o da cida de. (Fonte: RAFAEL MANO, 2006)

A primeira e mais emblemática, é a do espaço iconográfico. Os edifícios das instâncias federal, estadual e municipal, foram locados em 
á reas onde os pedestres pudessem transitar e permear as ed ific ações, junto a grandes espaços livres, participando e convivendo de perto do cotidiano destes elementos. Nasciam assim os espaços monumentais da cidade, marcos urbanos, seguindo os princípios de percepção urbana de Lynch.

A segunda categoria se encontra nas quadras residenciais $e$ comercia is, respeitando a lei 6766 , que destina $35 \%$ da área de cada uma para espaço livre. As quadras comerciais se situam junto a Praça dos Girassóis, e tem a função de atender o comércio na escala da cidade, nas quais também foram reservados espaços livres públicos seguindo os princípios do plano.

\begin{abstract}
"Prevalecem para o Micro Parcelamento, como facultado pelo art. 4, inciso I e parágrafo 1 da lei 6766 de dezembro de 1979, um mínimo de $15 \%$ para as Áreas Públicas Municipa is e um mínimo de $35 \%$ para a soma destas com o sistema viário, computados sempre tendo como perímetro aquele definido pelos eixos das vias do sistema viá rio principal definido das glebas urbanas objeto de loteamento." (Lei munic ipal 468: ca pítulo III, a rt. 7 n II, 1994)
\end{abstract}

Cada quadra foi estipulada para ter um desenho próprio. A diferenciação dos traçados de cada uma define, segundo seus autores, seu caráter e identidade contemporâneo. Para Featherstone, nestas (cidade contemporânea), a ênfase não está somente no tipo de arquitetura nova, especificadamente designadas pós-modema, mas também na miscelânea estilística eclética e mais geral que se encontra na textura do ambiente edific a do urbano.(1995, p 98)

\footnotetext{
"A cidade, portanto, deverá desenvolver no seu todo, em uma escala gregária mais aconchegante, ficando os amplos planos verdes somente reservados aos espaços que caracterizam como "civitas". Quanto à escala "urbe", será garantida pelas inúmeras ruas centrais de pedestres que deverão resgatar aspectos positivos das cidades antigas. Essas passagens deverão se abrir para praças com chafarizese árvores, podendo ser localizados no casario adjacente o comércio fino de varejo, como pequenas lojas, cafés, pousadas e edifícios para escritónios, etc." (PLANO BÀSICO/MEMÒRIA, 1989)
}

A terceira categoria refere-se às áreas de presenvação e proteção. Trata-se de um sistema de espaços livres na cidade em meio à formação 
urbana já consolidada, delimitando o contexto natural e o antrópico. Os rios que correm da Serra para o lago, alimentando o Rio Tocantins, não são apenas as bordas natura is e limites para o crescimento da cidade, mas estruturam um sistema de espaços livres fundamental para sua qualidade ambiental. Propõe-se um sistema de áreas verdes composto pelo parque Ecológico, Parques Urbanos, Parques Lineares, pelas áreas Verdes Comunitárias, que alcançarão um índice de $19 \mathrm{~m}^{2} /$ habitante, superando portanto os índices intemacionais estabelecidos pela UNESCO.(PLANO BÁSICO/MEMÓRIA, 1989)

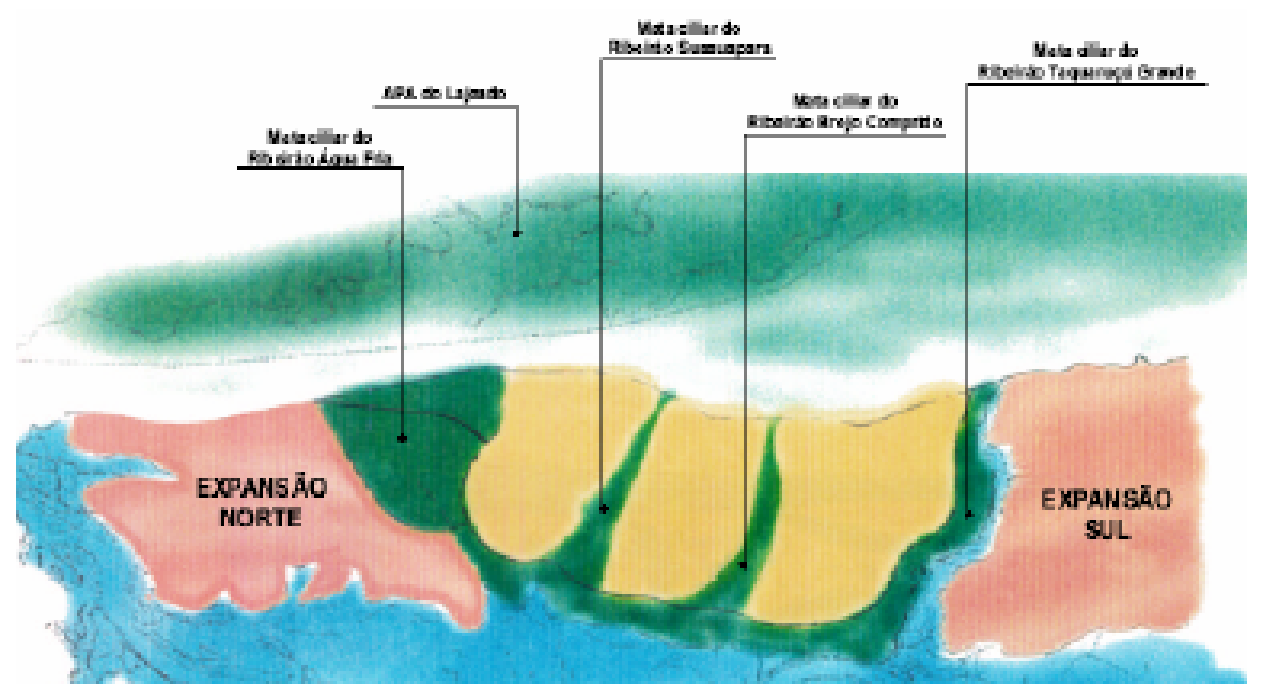

Fig. 28, Áreas de preservação e proteção de Palmas segundo o plano. (Fonte: IPUP, 2002)

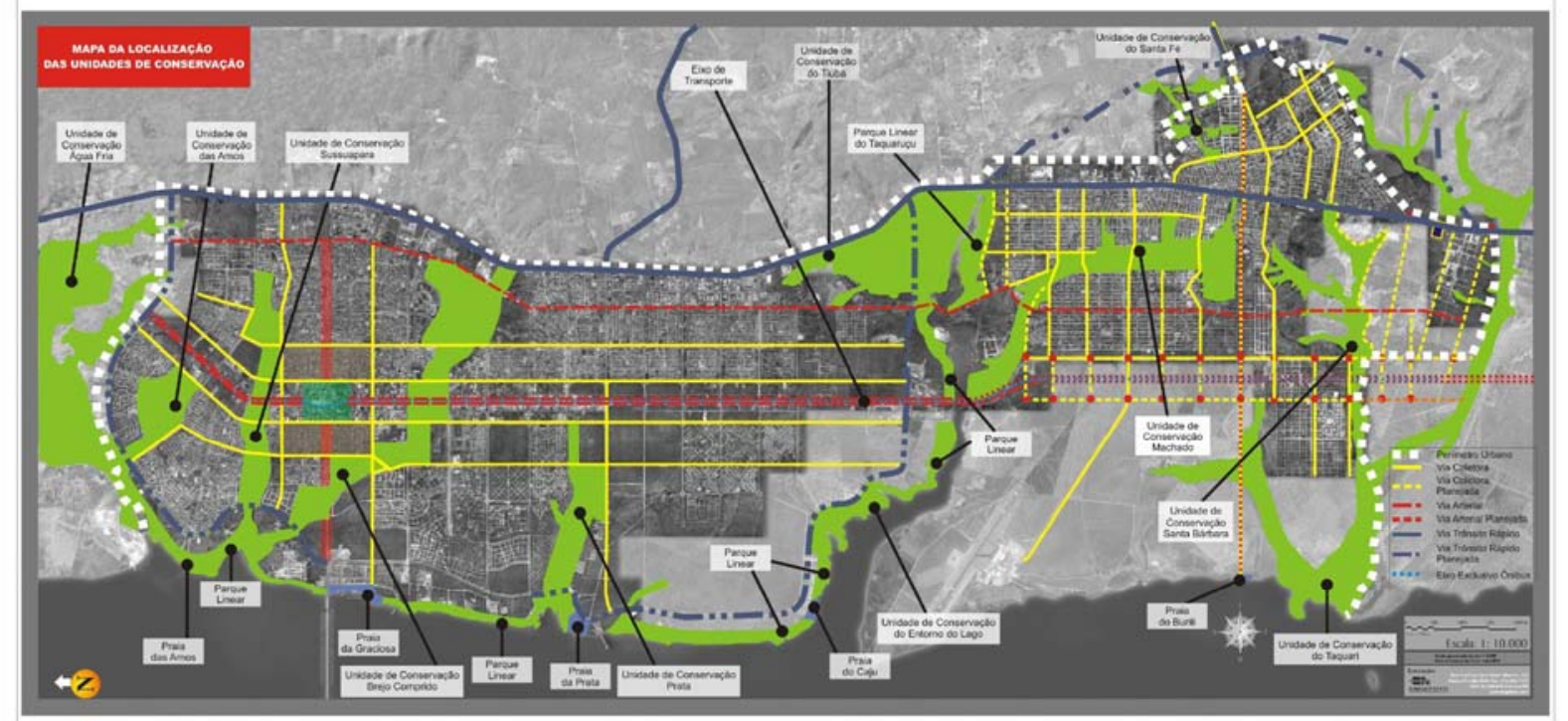

Fig. 29, Áreas de Conservação proposta pelo Novo Plano Diretor. (Fonte: SEDUH, 2007) 
A quarta categoria é a dos espaços livres utilitá rios. Esses a presentam função estrutural na cidade, seja pela manutenção do zoneamento proposto, pela resenva de áreas para o transporte ou por outros elementos de seu desenvolvimento. Este é o caso da Avenida Teotônio Segurado, eixo estrutural da cidade, que contém uma "ilha" de área verde destinada inicialmente ao transporte de massa, mas que se tomou durante a construção de Palmas, um ícone do progresso ao rasgar o cerrado existente e renegara paisagem natural como elemento compositivo.

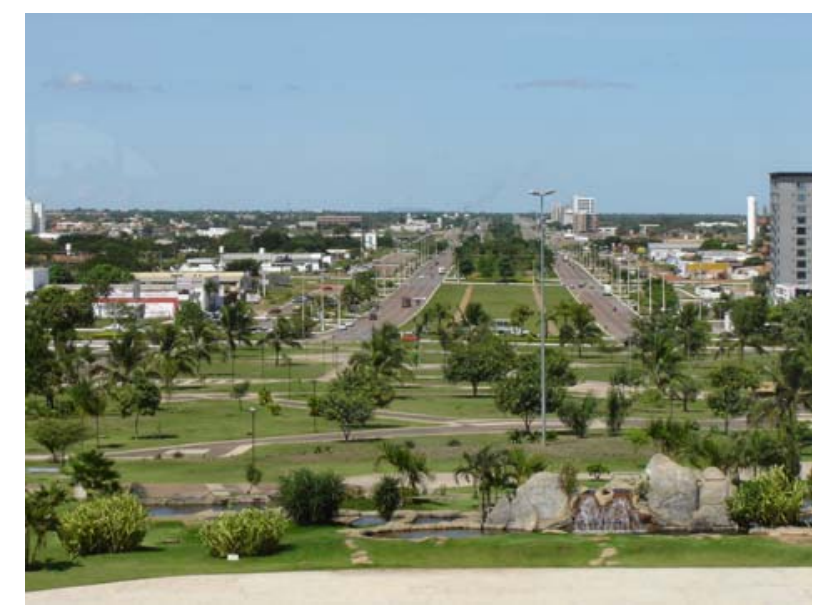

Fig. 30, Espaço livre utilitá io da cidade: Avenida Teotônio Segurado. (Fonte: a utor, 2005)

As diferentes formas de apropriação durante 0 processo de construção da cidade, incidem diretamente na hipótese levantada neste trabalho. A vitalidade desses espaços se dá através de uma dinâmica cultural que se estabelece através da diversidade criada a partir dos processos sociais, em detrimento às regras e determinações do projeto. A cidade revela que, a falta de uma visão integrada entre os elementos urbanos capazes de atrair a população para o uso público, gerou espaços ociosos e sem vida, que a relação entre espaços verdes e habitantes não revela o grau de qualidade do espaço, e que uma nova ecologia inspira a necessidade da construção de sua paisagem, integrando a natureza, arquitetura e os espaços urbanos a uma nova identidade, miscigenada e inserida no seu contexto cultural. 


\section{Um breve histórico da "esculhambação"}

Passado e presente caminham lado a lado na construção do espaço urbano de Palmas. Desde a polêmica idéia de construir uma nova capital20 até a atualidade, se confundem na relação tempo-espaço, e faz com que os moradores participem ativamente do processo da formação de uma nova cidade.

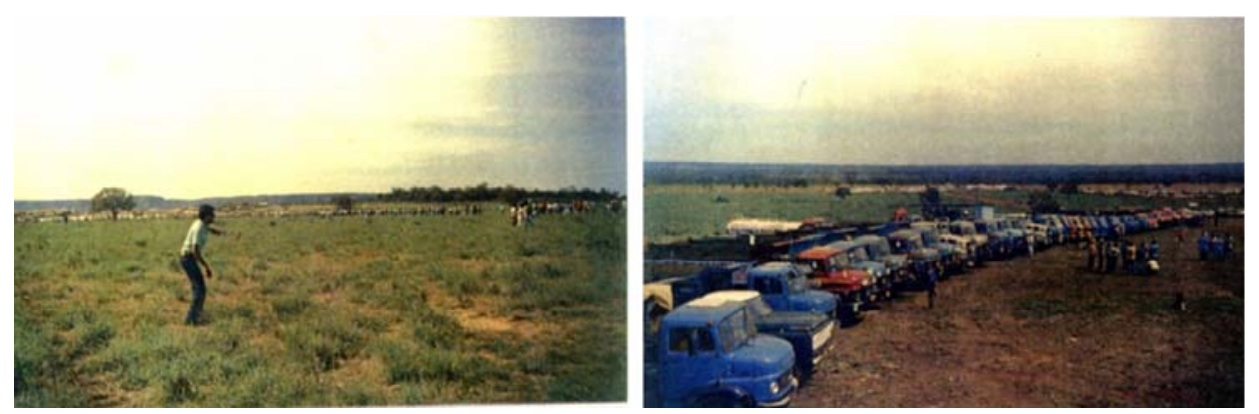

Fig. 31, Chegada a Palmas - Iníc io das obras. (Fonte: URA, 1995)

Mas em que parte deste processo o desenvolvimento da cidade rompe com o plano, descaracterizando a sua concepção inicial e sacramentando os problemas que a cidade enfrenta na atualidade? A ação do govemo que se encarregou de ser o principal loteador e gestor do plano proporcionou uma situação de desenvolvimento na cidade que nem os mais hábeis planejadores urbanos poderiam evitar - a cidade era um ideário político e não urbano. Independente do plano, provavelmente estas ações oc orreriam de qualquer maneira.

Então para que uma nova capital? Não foi somente para acabarcom uma disputa política entre cidades, mas para legitimar o desenvolvimento do novo Estado. Neste caso, o novo trazia consigo a modemidade, não só urbana, mas também econômic a e principalmente social que a região tanto necessitava: símbolos para abastecer um novo ideário de sociedade. O plano deveria trazer consigo um conceito de contemporaneidade para ressaltar o momento que se iniciava.

20 Para acabar com a disputa entre as duas principais cidades do norte de Goiás, Gurupi ao sul e Ara guaína a o norte, optou-se por construir uma nova capital, localizada no centro do Estado. 


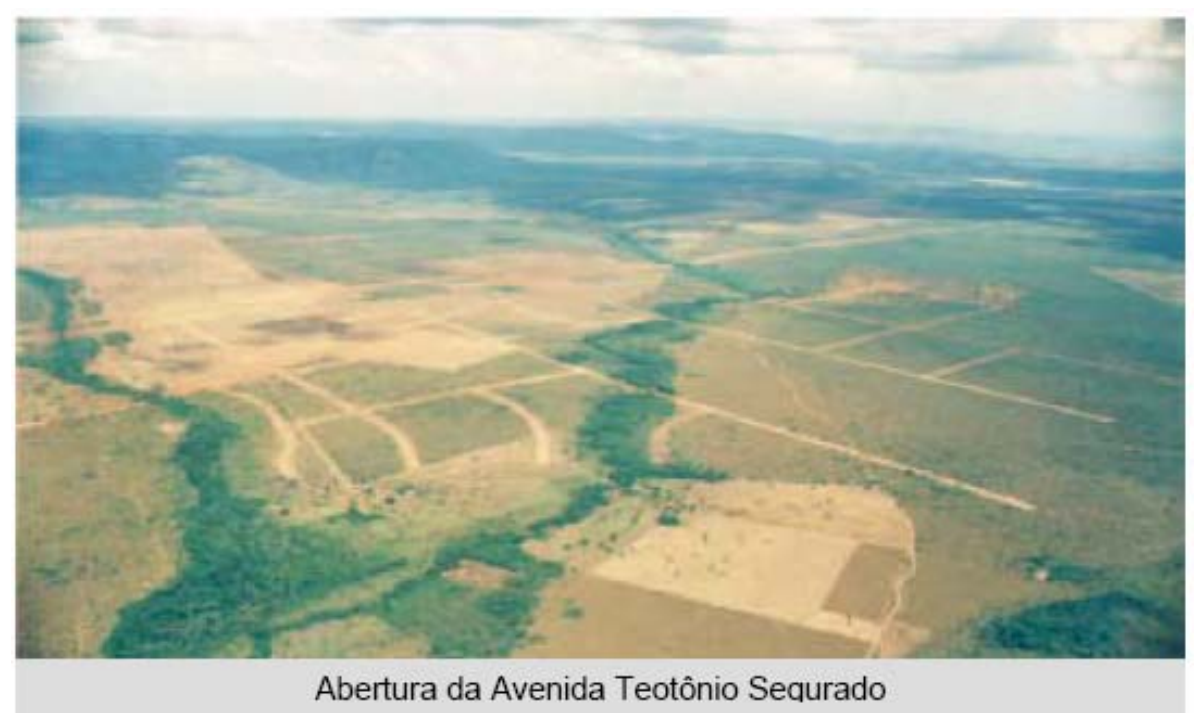

Fig. 32, Processo de implantação e urbanização da Cidade. (Fonte: IPUP, 2002)

Mesmo com todos os questionamentos urbanísticos que incidiram sobre o plano de Lúcio Costa, o projeto de Palmas se caracterizou novamente pela grandiosidade dos espaços, proporcionando uma nova imagem e simbologia da magnitude que se configura pelo urbano. A Praça dos Girassó is e a Avenida Teotônio Segurado são exemplos desta.

Na apresentação do projeto para a nova capital, as perspectivas da cidade reproduziam uma conformação de edifícios deteminados pelo ordenamento volumétrico e disperso, lembrando a relação espacial do tecido urbano de Brasília. Uma imagem figurativa como esta não representava a expectativa da organização da cidade, mas apenas preenchia o espaço com volumes esquemátic os para demonstrara imagem do plano (Fig. 33).

Este pequeno fato remete a falta de acordo entre o que se esperava e a realidade destes espaços urbanos. Embora a perspectiva fosse ilustrativa, ela trazia uma organização, uma orientação de como a cidade deveria se desenvolver. A única parte da cidade que se desenvolveu como na perspectiva foi o espaço destinado aos órgãos estaduais, o Palácio Araguaia, as secretarias e a gigantesca Praça dos Girassóis, todos os símbolos do poder do estado. 


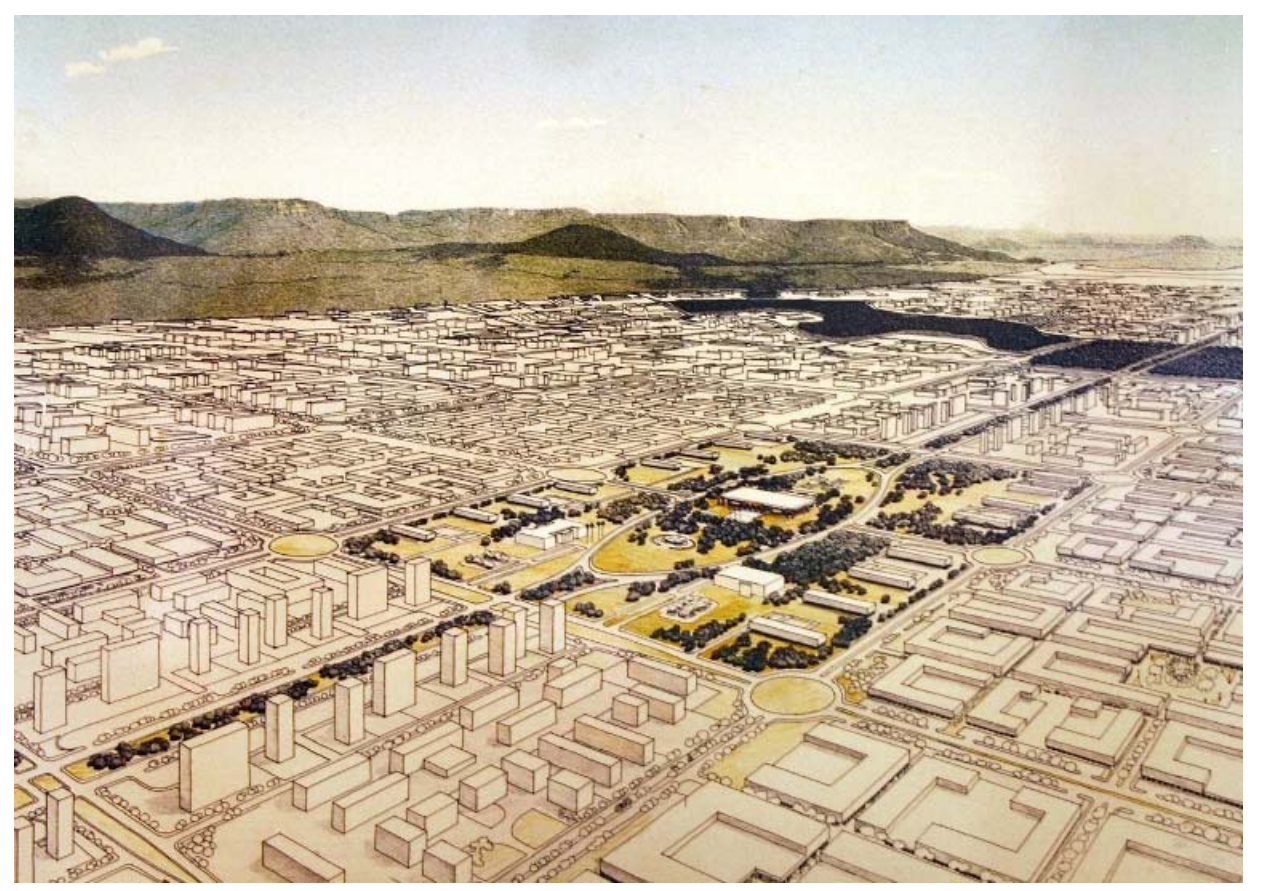

Fig. 33, Perspectiva da cidade na apresentação do projeto. Percebe-se um esquema volumétrico de gabaritos, e não da criação de um projeto urbano onde o espaço edificado e o livre se completem na produção da cidade. (Fonte: SEMUC, 2006)

Embora o determinismo da arquitetura, por vezes, não produza uma diversidade que é sadia para a população, não deteminar os efeitos causados por esta, prejudica sua qualidade. Produzir o espaço tradicional requer entender os hábitos de uma sociedade. A complexidade urbana não se reduz à esquemas volumétric os e a determinações de gabaritos, mas sim pela formulação de interfaces capazes de gerar a urbanidade através da apropriação e construção do espaço. Neste ponto, o plano da cidade se caracteriza por um modelo intermediário, de determinismo e interlocução entre espaço e sociedade.

Analisando os desenhos da apresentação da cidade pode-se obsenvar que o "plano" previa um crescimento ordenado e programado para o teritório geográfico (Fig. 34). O plano projetava o crescimento em faixas no sentido norte-sul, sempre delimitadas pelos limites do antrópico e da natureza, principalmente os fundos de vale. De acordo com o plano da nova capital, estipulado pelo Grupo 4, a cidade deveria ocupar todo o seu temitório no ano de 2010. Em 2006, a cidade morfologicamente se distancia desta estratégia, e redesenha o seu espaço, utilizando as áreas destinadas a 
futuras expansões da cidade para locar grande parte da população, principalmente os trabalhadores que chegaram no início da construção e não tinham condições de se estabelecer na área central.

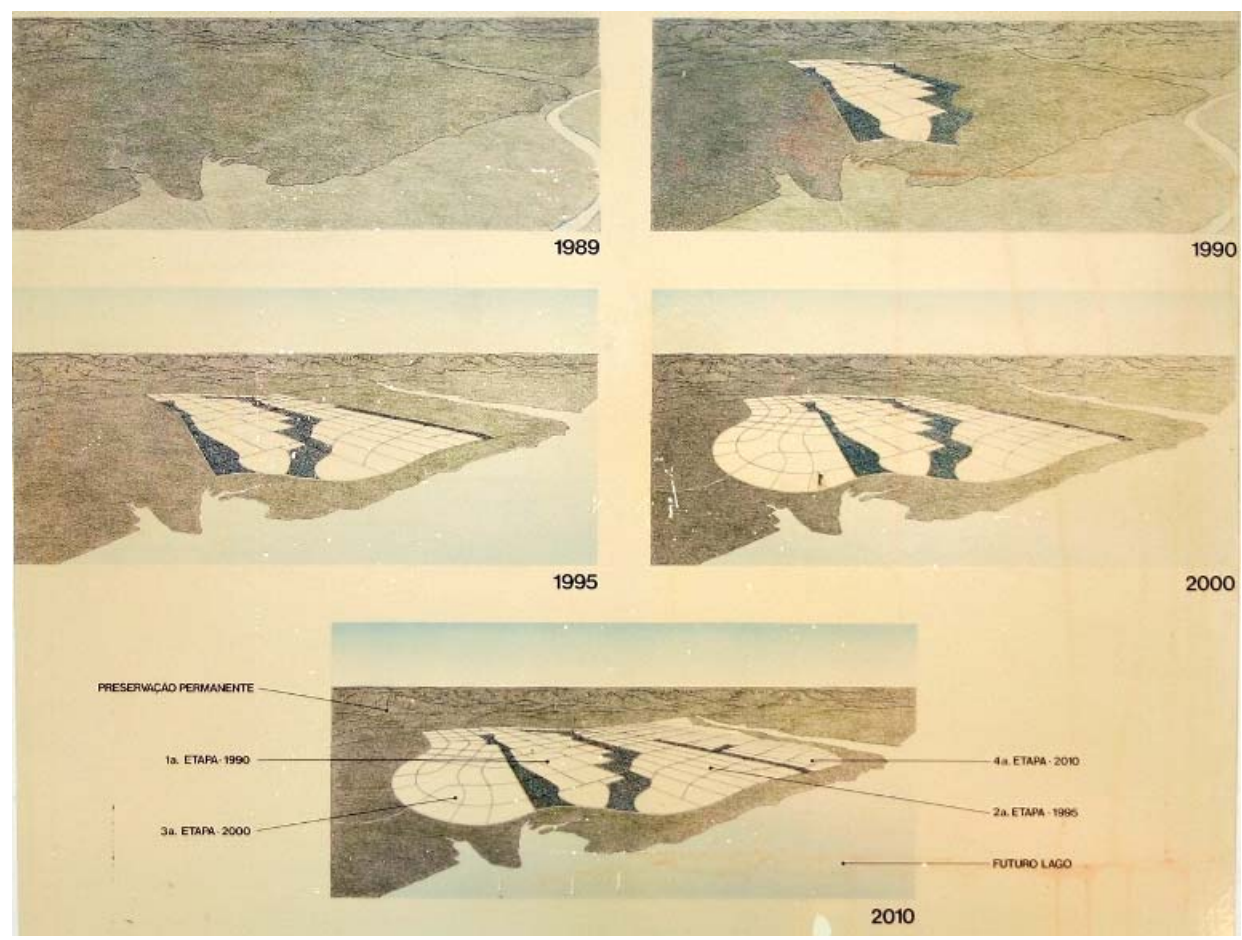

Fig. 34, Etapas de crescimento da cidade a té o ano de 2010 e a construção do lago que se deu no a no 2002. (Fonte: SEMUC, 2006)

Os primeiros gestores da cidade e do estado foram os grandes inc entivadores das invasões, conc retiza das em bairros afasta dos da região central e que atualmente concentram metade da população do município. No Plano, as primeiras quadras abertas não obedeceram à estratégia da equipe técnica, sendo as primeiras abertas na ARSE 51 e 7221, justamente na área da segunda etapa de implantação da cidade. Esta urbanização desnorteou os rumos do plano como estratégia de ordenamento, e gerou uma nova realidade, que se por um lado descaracterizou-o, por outro criou uma relação de pertencimento e identidade, que só os novos processose os

\footnotetext{
${ }^{21}$ A história de ocupação de Palmas está presente na memória de muitas que a construíram. Entre eles se destaca o atual Diretor de Planejamento Temitorial, Luis Hildebrando Ferreira Paz, que em entrevista concedida relata o processo de ocupação da cidade, que se desvirtuou do plano original. Em Palmas, desde o início de sua construção, ele vivenciou o processo de abertura das quadras iniciais, fragmentando o espaço concebido pelo plano, e originando a atual forma da cidade. (Entrevista concedida em 20 de outubro de 2006)
} 
atores sociais puderam proporcionar, contribuindo para a consolidação de uma sociedade urbana diversifica da e que molda osespaços da cidade.

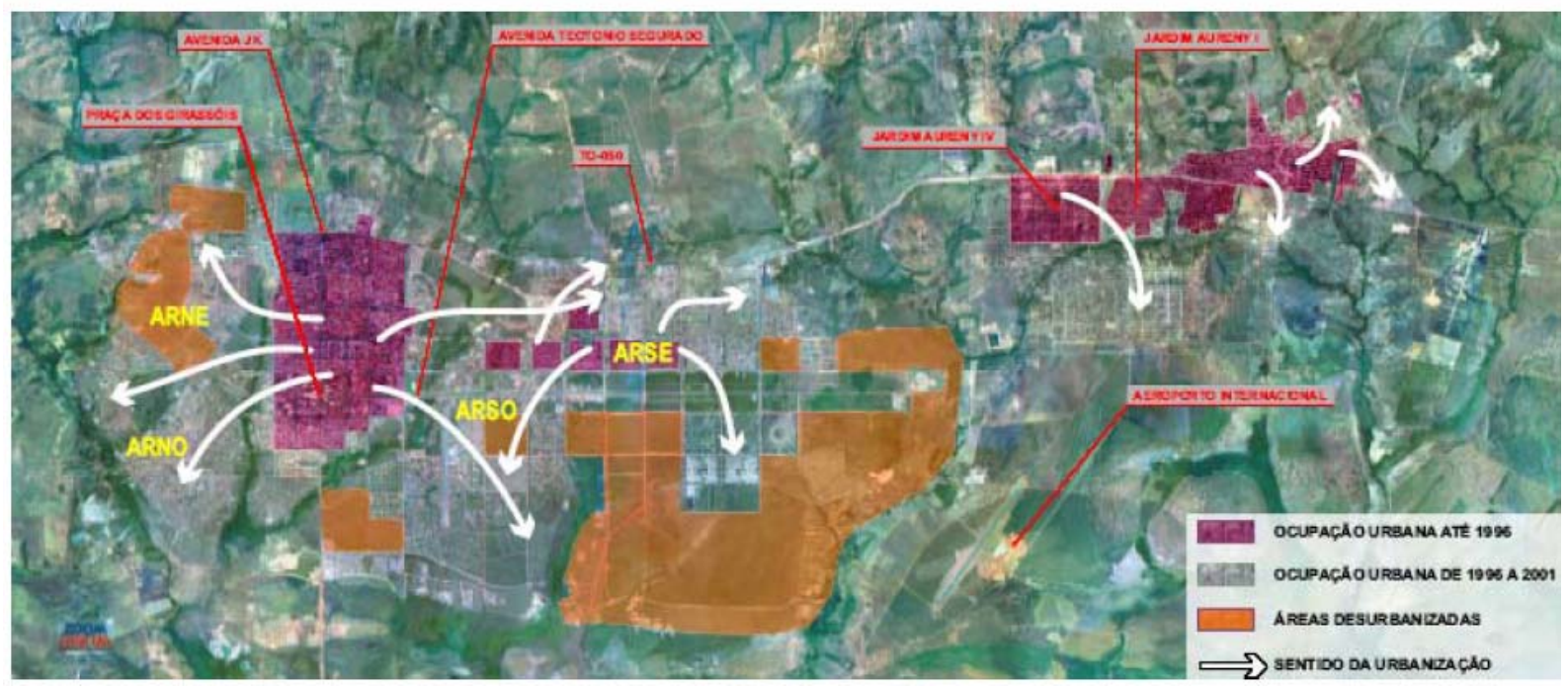

Fig. 35, Ocupação da cidade até 2002. No canto direito a cima os bairros Ta qua ralto e Aurenys, distritos criados para abrigara mão de obra da cidade. (Fonte: IPUP, 2002)

Cada gestão aplicou e interpretou o plano, desfigurando a idéia inicial, deixando a sua marca na forma de ocupar o teritório ainda desabitado. Essas feridas são reveladas atualmente pelo esforço dos atuais gestores, na tentativa de minimizar e solucionar os problemas causados pela sua a propriação indevida.

\begin{tabular}{|l|c|}
\hline \multicolumn{1}{|c|}{ Serviço } & Custo R\$ \\
\hline Coleta de lixo & $3.186 .820,03$ \\
\hline Varrição de vias e logradouros públicos & $5.265 .003,44$ \\
\hline Remoção de entulho & $407.267,33$ \\
\hline Serviço de tapa buraco & $705.223,96$ \\
\hline Roçagem & $1.028 .233,51$ \\
\hline Conservação de praças e parques & $3.319 .414,16$ \\
\hline Reforma meio fio e manutenção da drenagem & $1.105 .173,37$ \\
\hline Iluminação pública & $3.379 .890,95$ \\
\hline TOTAL & $18.397 .026,75$ \\
\hline
\end{tabular}

Fig. 36, Ta bela de custos tota is de serviç os urbanos - Ba lanço Geral 205. (Fonte: SEDUH, 2006)

O crescimento da cidade desvirtuou-se do projeto original, agregando em seu desenho bairros afastados do centro, e uma grande quantidade de vazios gerados pelo seu espalhamento. Isso tomou Palmas uma cidade com 
altos custos de manutenção, tendo que construir uma grande infra-estrutura viária, de saneamento e de transporte para uma população pequena e não concentrada.

Quando fossem abertas todas as quadras na área do plano, calculava-se que poderiam viver ali com todo conforto e estrutura, cerca de um milhão e duzentos habitantes. Na parte sul e norte já estavam previstas áreas de expansão, que poderiam depois de desenvolvida a área do plano, ser novasopções de ocupação para abrigar novosmoradores.

A ação do govemo fez com que a expectativa de formação da cidade, por etapas e cadenciada, onde a infra-estrutura seria construída à medida que malha fosse se expandindo, foi substituída por uma ocupação espalhada. O que deveria a contecer em 20 anos demorou 10 e até hoje se paga por esta ação dos gestores. Segundo dados da prefeitura de Palmas, o item "urbanismo" é responsável por $40 \%$ dos gastos a nua is do orçamento munic ipal, incluindo as altas taxas de ma nutenção dos espa ços verdes.
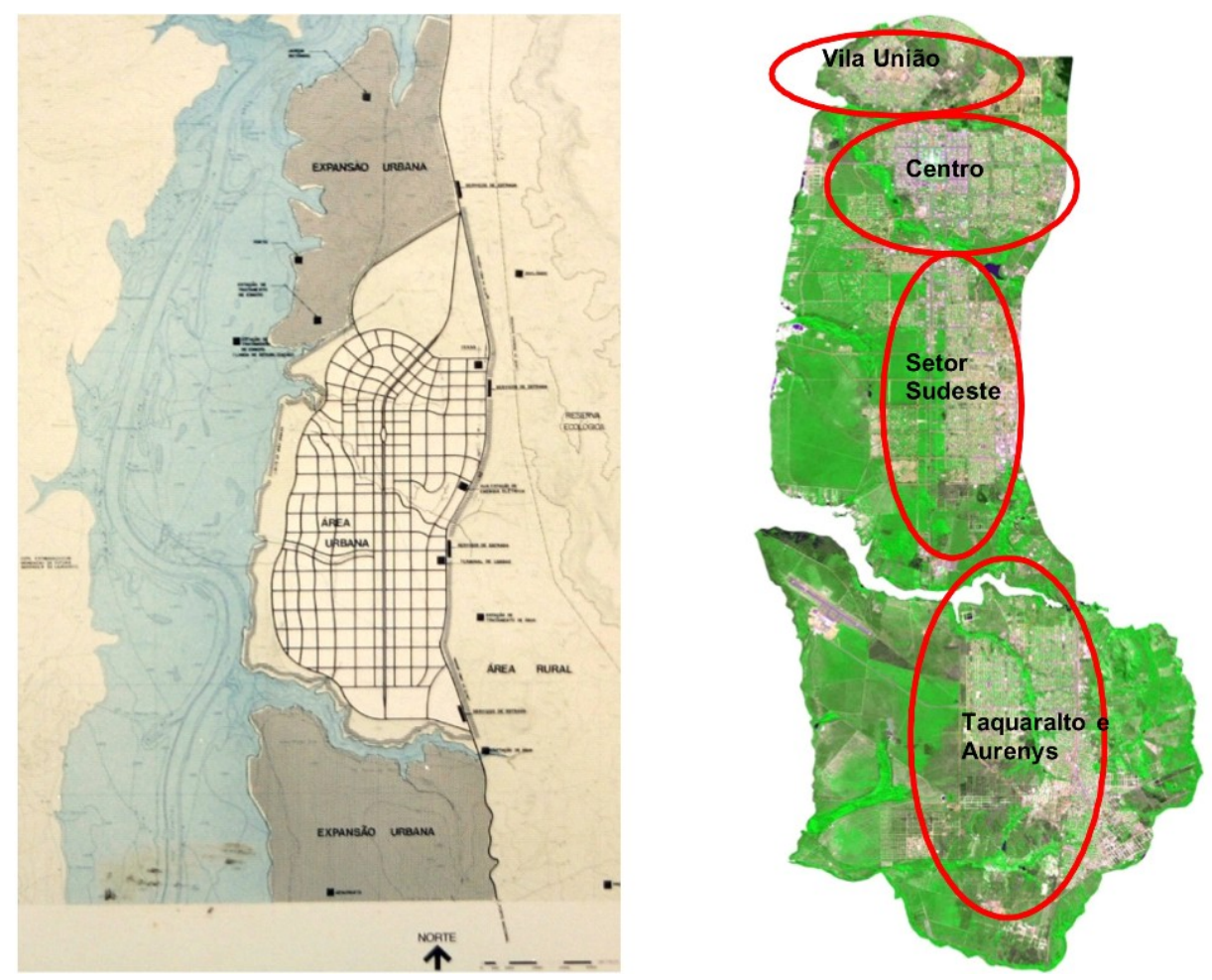

Fig. 37, Morfologia do Plano de Palmase Morfologia atual da cidade. Na primeira o traçado define o desenho urbano. No segundo o traçado é abstraído por uma nova forma que se originou com o desenvolvimento da cidade. (Fonte: SEDUH, 2006) 
Na fig. 37 percebe-se a morfologia atual da cidade, que extrapolou os limites do projeto antes do previsto. Nesta figura estão definidas as quatro áreas que definem a estrutura urbana de Palmas, e se comportam de formas diferenciadas. A primeira é a Vila União, região que se desenvolveu a partir da invasão promovida pelo Govemador Moisés Avelino ${ }^{22}$ em 1992. A segunda é a região central, onde se concentram as instâncias do poder público e do comércio, e as principais quadras. A terceira é a região que se desenvolveu a partir da abertura dasquadras Arse 51 e 72, que promoveu a ocupação no setor sudeste. A quarta são os distritos que cresceram anexados à cidade, Taquaralto, Aurenys e Taquaris, todos promovidos pela ação conjunta dos gestores e comunidade.
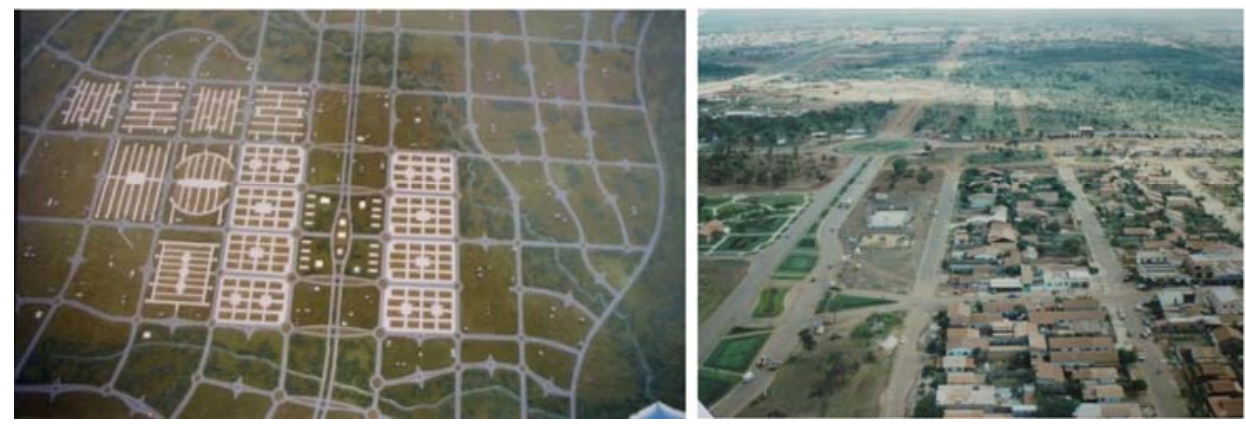

Fig. 38, Projeto para as primeiras quadras de Palmase foto aérea da quadra ARSE 51, a primeira a berta à população junto à prefeitura. Percebe-se nesta última o vazio cria do entre a quadra e o Pa lácio do govemo do canto superior esquerdo da foto. (Fonte: SEMUC, 2006)

A Fig. 38, representa a maquete do projeto para as primeiras quadras, desenhadas pelo Grupo 4 em parceria com o escritório do arquiteto Ruy Othake, e a Arse 51, primeira quadra aberta. Nestas duas imagens temos o limite exato entre o projeto e a urbanização da cidade. Na primeira o traçado está definido e as áreas destinadas ao poder estão delimitadas pela grande Praça Central. Em sua volta está o centro comercial, e a esquerda as primeiras quadras residenciais que deveriam ser abertas, seguindo a estratégia de desenvolvimento por etapas. O projeto apresenta uma

\footnotetext{
22 Moisés Avelino foi o govemador responsável pela oc upação da Vila União. Em entrevista concedida ele avalia que foi uma maneira de conter as inva sões em áreas de proteção da cidade, o que estava ocorrendo principalmente em áreas de fundo de vale, e locar a população carente não distante do centro, como em Taquaralto e Aurenys, mas perto da região central. (entrevista concedida em $27 / 10 / 2006)$
} 
fragmentação espacial baseada em princípios funcionais, tendo no traça do viário e nas unidades de vizinhança, os principa is elementos estruturadores da urbanização. Cada unidade é fragmentada, formando um grande loteamento urbano, que inicialmente se encontravam nas mãos principalmente do poder público, e que direcionou a especulação na cidade. Esta dimensão da gestão resultou no fim do plano antes mesmo de sua implantação.

Os argumentos utilizados para a abertura da Arse 51 foram a de preservar as quadras centra is durante a construção das primeiras estruturas necessárias para o funcionamento da cidade. Isto gerou um novo pólo de desenvolvimento urbano para o sul.

Segundo o diretor da SEDUH, Luiz Hildebrando, que chegou a Palmas em 1990, acompanhando todo o processo da construção da cidade, foi a gestão pública que deteminou os primeiros loca is a serem ocupados. Como a estrutura do govemo demandava um como de empregados de diferentes escalas, cada grupo foi locado segundo distinção social. A classe inferior foi locada em Taquaralto, iniciando a sua formação. A classe intermediária se estabeleceu na Arse 72, onde conjuntos populares foram construídos para suprir a demanda de moradia. Por fim os trabalhadores que ocupavam os altos cargos do govemo ganharam lotes na Arse 14, primeira quadra central a ser ocupada. A distância entre as quadras gerou o espalhamento urbano da cidade atual, pois cada uma se configurou como centralidade e promoveu o crescimento em seu entomo.

A ruptura entre plano e gestão deteminou a esculhambação das diretrizes de ordenamento previstas como essenciais para condicionar seu o crescimento, revelando as arbitrariedades ocomidas na história da construção da cidade, e moldando essa nova realidade. 


\section{A formação e transformação dos espaços públicos e m Pa Imas}

Os espaços públic os de Pa Imas representam o ponto de ligação entre o cotidiano de seus moradores e o traçado planeja do da cidade. Eles são os símbolos da qualidade de vida proposta por seus planejadores, da relação com a paisagem do cerrado e das diferentes formas de expressão cultural. Estas áreas enfatizam o espaço livre perdido em muitos centros urbanos do Brasil, mas que agora, em uma cidade planejada, poderiam ter um novo signific a do na conformação da urbanidade.

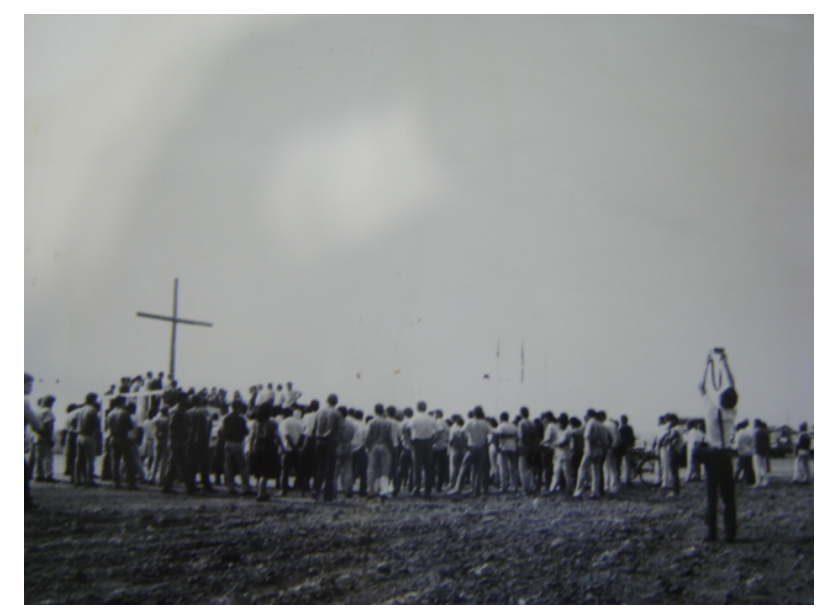

Fig. 39, Primeira Missa Campal na Praça dos Girassóis em 1989. (Fonte: SEMUC, 2006)

A missa campal realizada na Praça dos Girassóis, no ano de 1989, marca a primeira manifestação de a propriação e de ocupação pública de um espaço ainda em construção, a través de uma cenimônia que denotou a este, um caráter de local dedicado a manifestações cívicas, referenciandoo como marco espacial de uma nova era de "esperança e conquista".

“Trabalhar sobre o espaço, porém, é trabalhar sobre a memória e a história, é construir o simbólic o que permite vê-lo como manifestação do público, estrutura social plural e coletiva e não apenas o imaginário, reflexo de desejos e interesses privados das minorias." (LEITE, 1997, p 107) 
Os espaços públic os se caracterizam dentro das quatro categorias de espaço livre descritas na gênese urbana de Palmas, apresentadas anteriomente neste trabalho. A Praça dos Girassó is se insere na primeira categoria, o iconográfico. Esta foi se constituindo e muitas transformações ocorreram até a sua atual configuração. Palco de diversas atividades, ela se toma a cada dia o mais importante espaço público, onde os trabalhadores do centro comercial e das secretarias do govemo, esportistas, tra nseuntes, visitantes, estudantes e outros, a utilizam como área de recreação, contemplação e principalmente para manifestações do cotidiano.

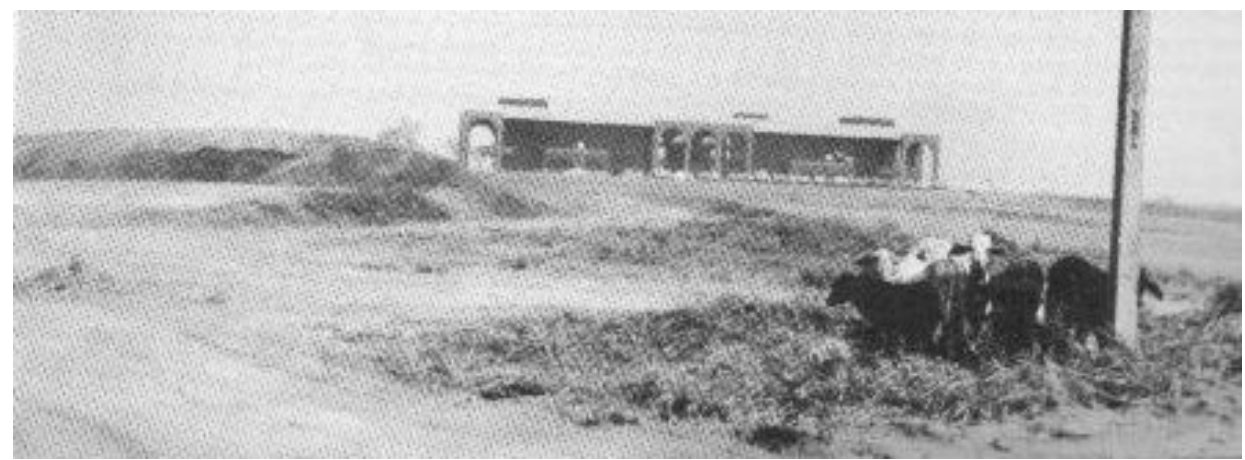

Fig. 40, Aspecto da Praça dos Girassó is no início de Palmas. (Fonte: MALHEIROS, 2002)

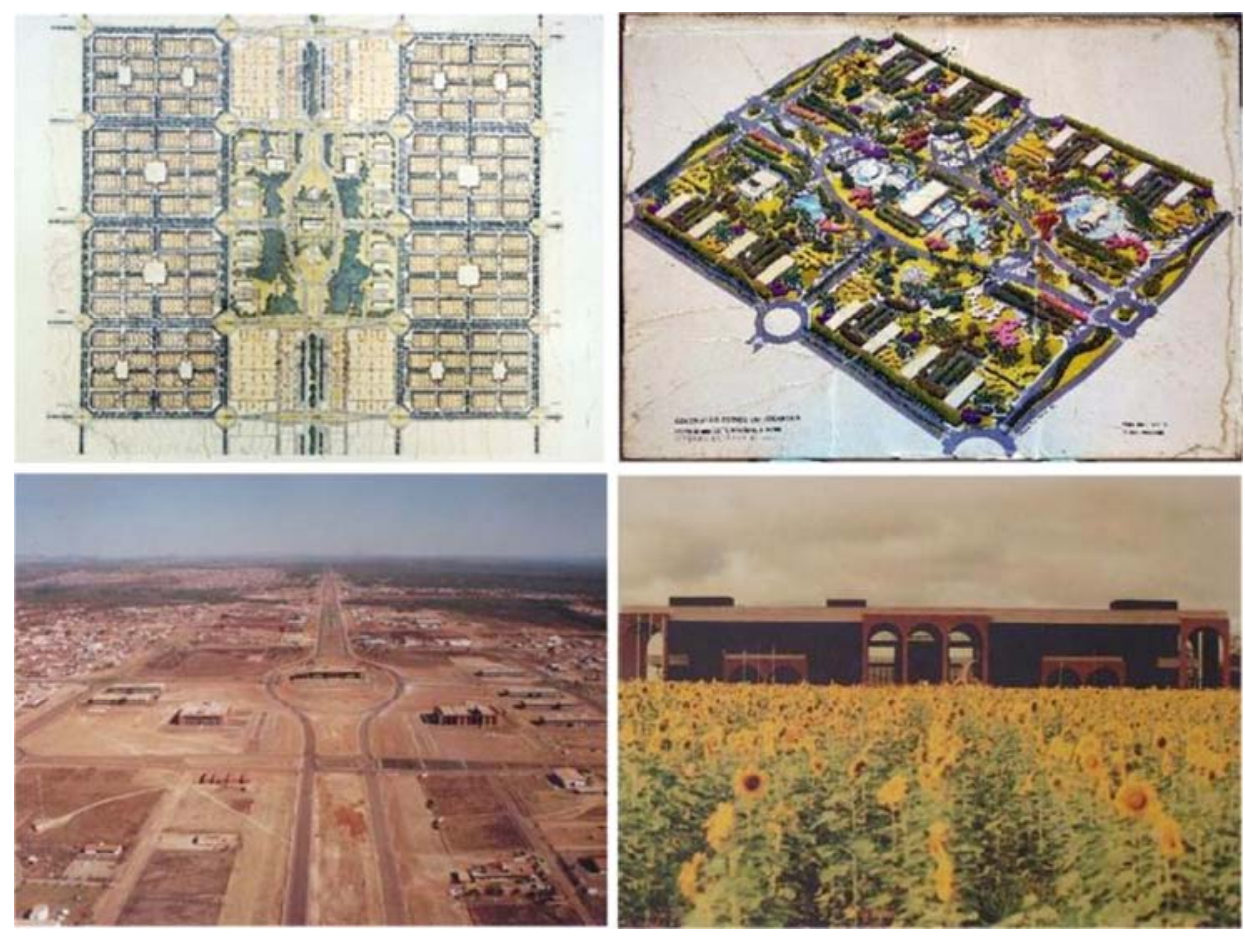

Fig. 41, Processo de idealização e fase da construção da Praça dos Girassóis, a inda com a rotatória ao redor do Palácio Araguaia. (Fonte: SEMUC, 2006) 
Este grande espaço social é prejudicado por um desequilíbrio ambiental, marcante em alguns pontos de Palmas, a falta de sombra, ocasionada pela política inicial de devastação da mata nativa, substituindoa por espécies que ainda não atingiram o porte adequado para compensar este equívoco.
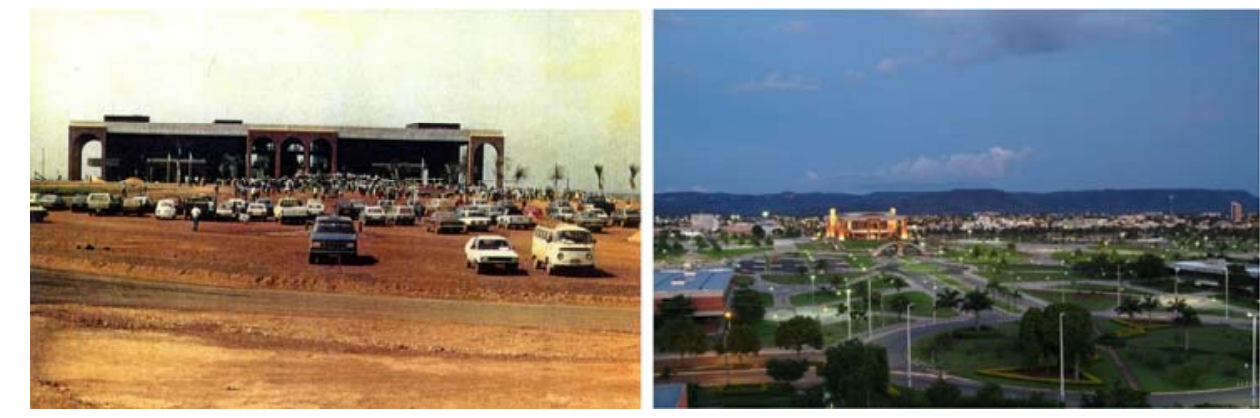

Fig. 42, Aspecto inicial e atual da Praça dos Girassóis com a o Palácio Araguaia no primeiro plano, seguida da cidade e da Serra do Lajeado a o fundo. (Fonte: SEMUC, 2006; www.palmas.to.gov.br, 2005)

O ideário de espaço público se deparou com um planejamento urba no no qual o setor priva do seria responsável por parte do financiamento para a implantação, proveniente das vendas dos lotes pelo estado, gerido por uma gestão preocupada em constituir inicialmente os espaços ic onográfic os como símbolo de uma nova era. Os conflitos por essa relação são decisivos para a esfera pública e para o sistema de espaços livres. Para Rabotnikof, a esfera pública extrai seus impulsos da assimilação privada de situações sociais problemáticas que resumem em histórias de vida. Assim, a revitalização do espaço público se identifica com o redescobrimento da sociedade civil. (1995, p 02)

Outro espaço iconográfico que se constituiu pela gestão é o Bosque dos Pioneiros. A proposta inicial, de manter parte das espécies nativas na intervenção paisagística, refletiu uma preocupação com aspectos ambientais e culturais, decisivos na apropriação do local pela população, com um uso intenso em alguns períodos da semana, e uma representatividade que ultrapassa a condição de Paço Municipal. 


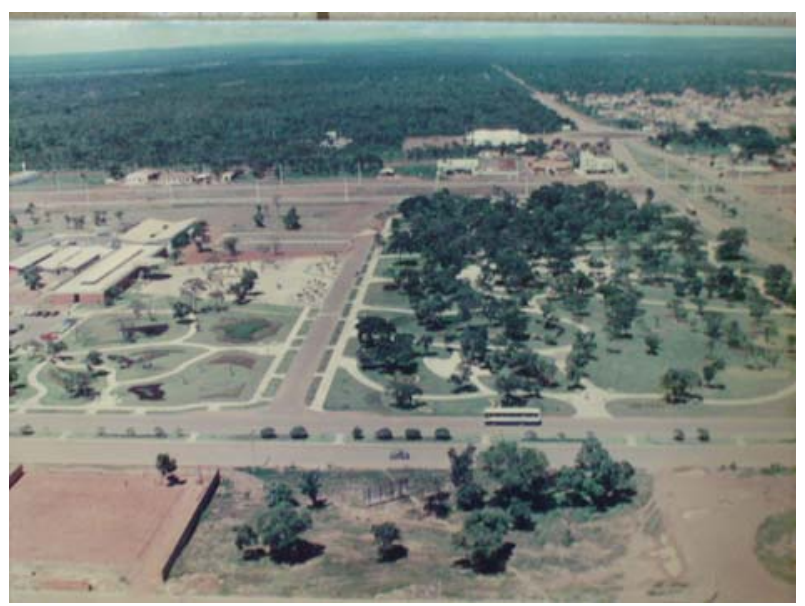

Fig. 43, Aspecto inicial do Paço Municipal e do Bosque dos Pioneiros. (Fonte: SEMUC, 2006)

O uso intenso da praça é um indicador de qualidade ambiental, onde o sombreamento e o esmero no tratamento paisagístico, resultam na apropriação das ma is diferentes camadas socia is da população de Palmas. Isso ocorre com o auxilio de eventos que contribuem para uma ocupação mais efetiva, mas que reforçam o papel da diversidade de acontecimentos que espaçospúblicos tendem a abranger.

A maior transforma ção da paisagem presenciada pelos moradores, foi à conclusão do lago que se fomou com a construção da represa do Lajeado. Já prevista antes da concepção da cidade, a escolha da área de implantação de Palmas resultou, entre outros fatores, pela já delimita da cota máxima que o lago atingina. O plano teve como orientação esse limite, que seria concluído 12 anosapósa sua inauguração.

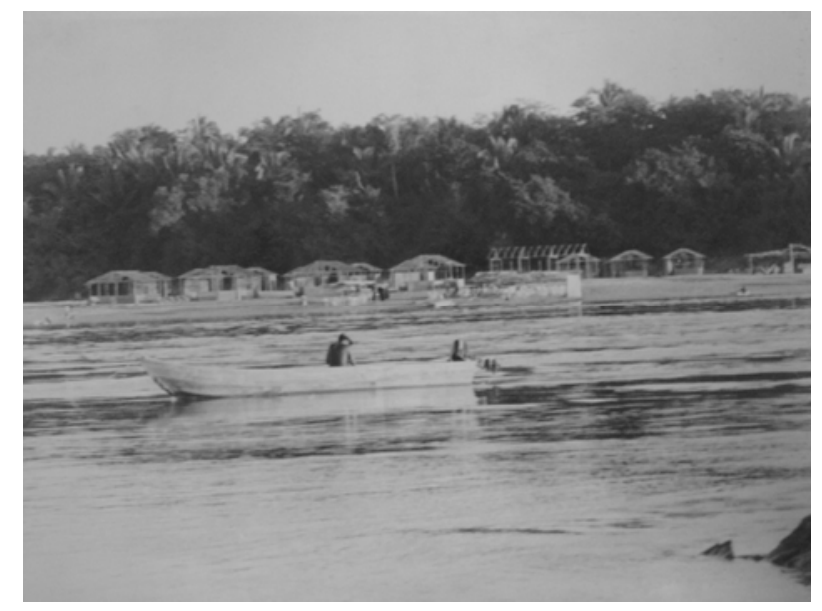

Fig. 44, Antiga Praia da Graciosa, quando a inda no Rio Tocantins. (Fonte: SEMUC, 2006) 
Essa mudança é tão significativa, que a especulação imobiliária se volta agora para a consolidação da faixa da onla como área de expansão da cidade. Este fato gerou uma série de propostas para a ocupação das margens do lago, devendo se constituir como o principal espaço livre da cidade, com inúmeras áreas verdes e diversas atividades de lazer e de uso público, permitindo aos moradores mais uma opção de interação com o grande potencial paisa gístico da região.

A orla da Graciosa, é um exemplo de espaço onde o projeto arquitetônico encontra seu limite nas formas de apropriação humana. Embora bem intencionado, e que seguiu o modelo doscalçadões de outras cidades do Brasil, a rtic ulando diversas atividades, o projeto não ga rantiu sua plena ocupação pela população. A orla teve como ideário a inserção da imagem de praia litorânea para a cidade de Palmas, aproveitando o potencial hídrico e promovendo uma expectativa formal de área com qualidade urbana e ambiental, que trouxe como significa do uma conquista para a cidade, tanto pela construção do lago, como pela expansão e consolidação da modemidade.

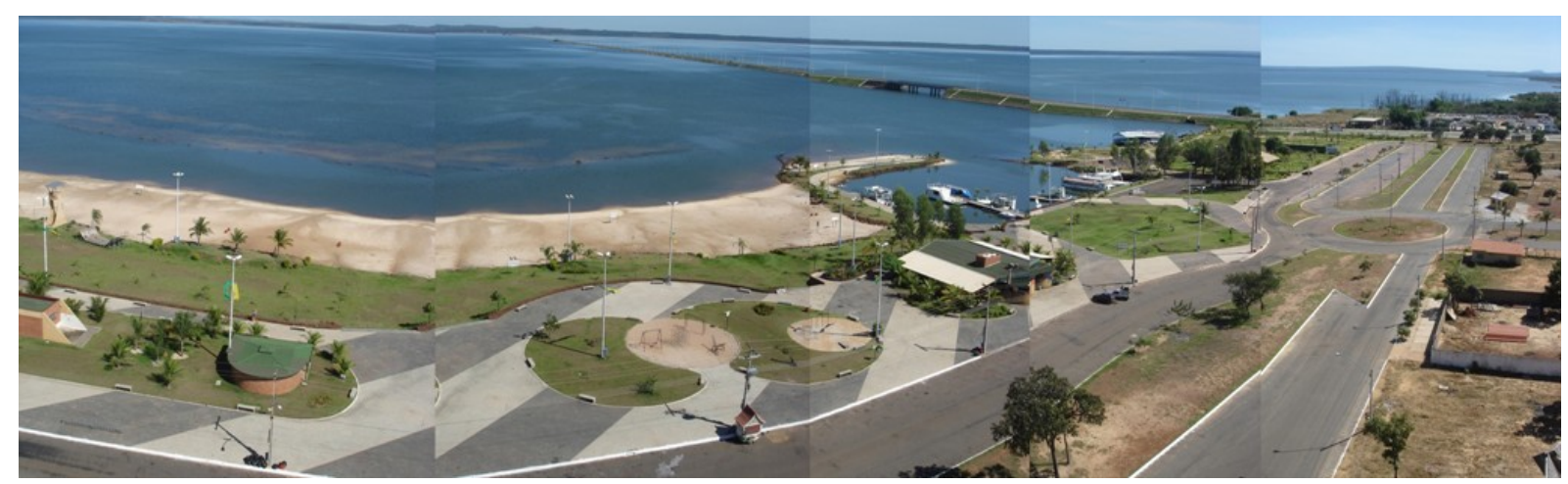

Fig. 45, Orla da Graciosa no Lago construído no Rio Tocantins. (Fonte: RAFAEL MANO, 2006)

Sem a mesma imagem e intervenção de uma orla urbanizada, a Praia do Prata, na conjunção do Rio Prata com o lago, e a Praia das ARNOS, na Vila União, do setor sudeste e noroeste, refletem uma situação diferenciada quanto a apropriação do espaço público. Nascidas como contraponto à orla da Graciosa, muito mais pelo anseio da população por um local de lazer junto às quadras residenciais, demonstram como a força civil garante o 
uso e a ocupação do espaço urbano, e criam um forte sentido de pertencimento ao local.

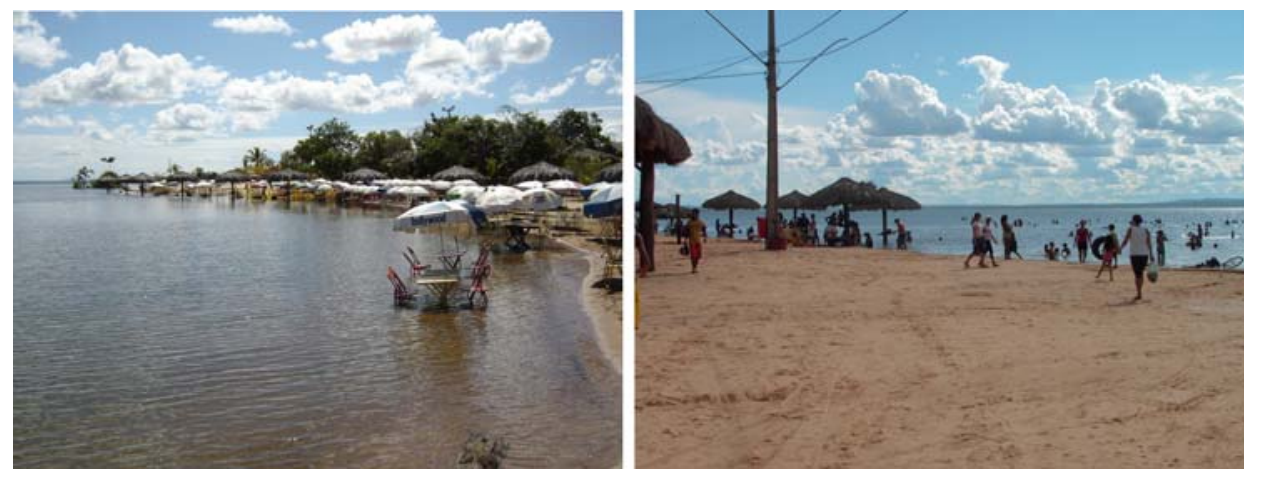

Fig. 46, Apropriação das Margens do Lago: Praia do Prata e da Amo. (Fonte: a utor, 2005)

Lugar das mais diversas manifestações populares, as duas praias remetem a uma estruturação espacial não pelo projeto em si, mas pela apropriação cultural ao meio natural existente. A ocupação das margens dos rios pela população do Centro-Oeste e Norte do Brasil, constitui uma importante interação entre espaço e expressão cultural, condicionada principalmente às condições natura is da região, onde nos meses de estiagem, os bancos de areia formados pela diminuição dos leitos dos rios são ocupados por milhares de pessoas como espaço de lazer e diversão. Para Leite, em um espaço povoado, a paisagem que se pode observar é, então, o produto do trabalho coletivo de uma sociedade sobre seu temitório e o processo social de sua construção. È a acumulação, no tempo, de práticas, técnicas, valores e símbolos culturalmente transmitidos às futuras gerações. (1998, p 65)

A constituição dos espaços públicos de Palmas reflete uma diversidade nem tanto projetual, mas de apropriação, de formação de áreas destinadas a atividades coletivas, públicas, cultura Imente significa tivas dentro desse novo contexto urbano. Estas caracterizam um cotidiano adaptado às condições locais, inserindo no espaço tradições, imaginários, memórias e costumes de cada morador, resultando em uma nova paisagem. 


\begin{abstract}
"O tipo de relação que se estabelece entre os habitantes e o lugar, originam-se sempre da forma de compreensão, interpretação e apropriação da natureza, concretiza-se no ato de ordenar o temitório, construindo a paisagem, e qualifica-se no projeto e no uso dos lugares, constituind o sua identida de." (LEITE, 1998, p 71)
\end{abstract}

A incomoração de aspectos regionais, por todos aqueles que chegavam e se propunham a enfrentar a poeira gerada pelas avenidas recém abertas, contribuiu para aumentar $o$ limite entre $o$ projeto $e$ apropriação, demonstrando diferentes olhares sobre o mesmo lugar. A chegada de pessoas de todas as regiões do Brasil fez nascer uma miscigenação de culturas e tra dições, propulsora de anseios, necessidadese costumes que influenciaram na construção da cidade, independente do plano e das diretrizes traçadas, e que contribuem para os acertos e problemas de algumas áreas. No caso de Palmas, a diversidade cultural é um fator que promove a sua urbanidade. Através dela, o senso de pertencimento e de identidade se conformaram junto ao seu processo de construção.

Não se trata de uma apologia ao não projeto, mas sim de um entendimento maior de como este pode ser um fator gerador da urbanidade. O projeto é a representação entre sujeito e objeto, sua ordem e seu caráter, impregnadas pela inconstância do ritmo e qualificadas pela dinâmica do tempo. (LETE, 1998)

A identidade que está se tentando constituir em Palmas pode ser vista em diversos monumentos, na arquitetura, na memónia fotográfica de um passado recente, e na necessidade em confimar cada vez mais o título de Capital Ecológica. A relação com o ambiente natural é vista como ponto chave para a criação de um comprometimento ecológico com a população.

Se por um lado esse aspecto remete uma aspiração positiva, é importante ressa lta r que o desenvolvimento histórico negou em grande parte esta preocupação na implantação do plano, onde máquinas destruíram centenas de hectares de cerrado para abrir as avenidas, canteiros e quadras, com conseqüências sentidas até a atualidade. Esse processo 
danoso se converteu em problemas comuns a muitas cidades brasileiras, mas que aqui poderiam ter sido evitados, já que a cidade foi implantada em plena discussão sobre os impactos do meio urbano sobre a natureza.

O senso de pertencimento não surgiu rapidamente, até porque praticamente não existia ao que pertencer. Isso criou um sentimento inicial de terra de oportunidades, onde o ganho financeiro e a exploração da terra suplantavam o sentimento de criação de civilidade.

A segunda categoria de espaço livre é detemina nte para caracterizar os limites do projeto urbano, e das interfaces entre espaço público e cultura. As quadras com melhor loca liza ção, junto ao centro e a zona comercial, são áreas que apresentam maior quantidade de espaços livres projetados, com praçasjá implantadase ruasanboriza das.

\begin{abstract}
"A contradição, é que com essa declaração os respectivos a rquitetos não concebem a visão socializada da cidade, preferindo pelo que nos parece, uma cidade a serviço da iniciativa privada, o público, o coletivo de Palmas se restringe às praças, avenidas e prédios institucionais, o restante é disposto, dentro do projeto, para ser construído pela inicia tiva privada. Então, contra ditoriamente, eles reclamam e dizem que $o$ projeto original da cidade está a mea ça do." (LIRA, 1995)
\end{abstract}

Na periferia, a utilização do espaço público é mais intensa do que no centro, principalmente nos finais de semana. Nestes dias, os moradores das quadras centrais se envolvem em sua esfera privada, mesmo com a presença de espaços públicos qualitativos, enquanto os da periferia se apropriam das ruas e dos terrenos vazios destinados à construção de praças como área de lazer, diversão e sociabilidade.

A terceira categoria é responsável pelas áreas de preservação que aos poucos estão se consolidando como importantes espaços públicos. 0 principal e mais emblemátic o é o Parque Cesamar, construído em 1998 para proporcionar aos moradores da cidade, uma área verde pública para diversas atividades de lazer. Este proporcionou a preservação do principal fundo de vale que delimita a área central, destacando-se em meio ao traçado ortogonal, costurando a trama urbana. Já o Parque Sussuapara foi 
criado pela gestão municipal (2000-2004), para prover à área Norte uma área de lazer. Esta não se consolidou, por fatores que serão demonstrados no próximo capitulo.
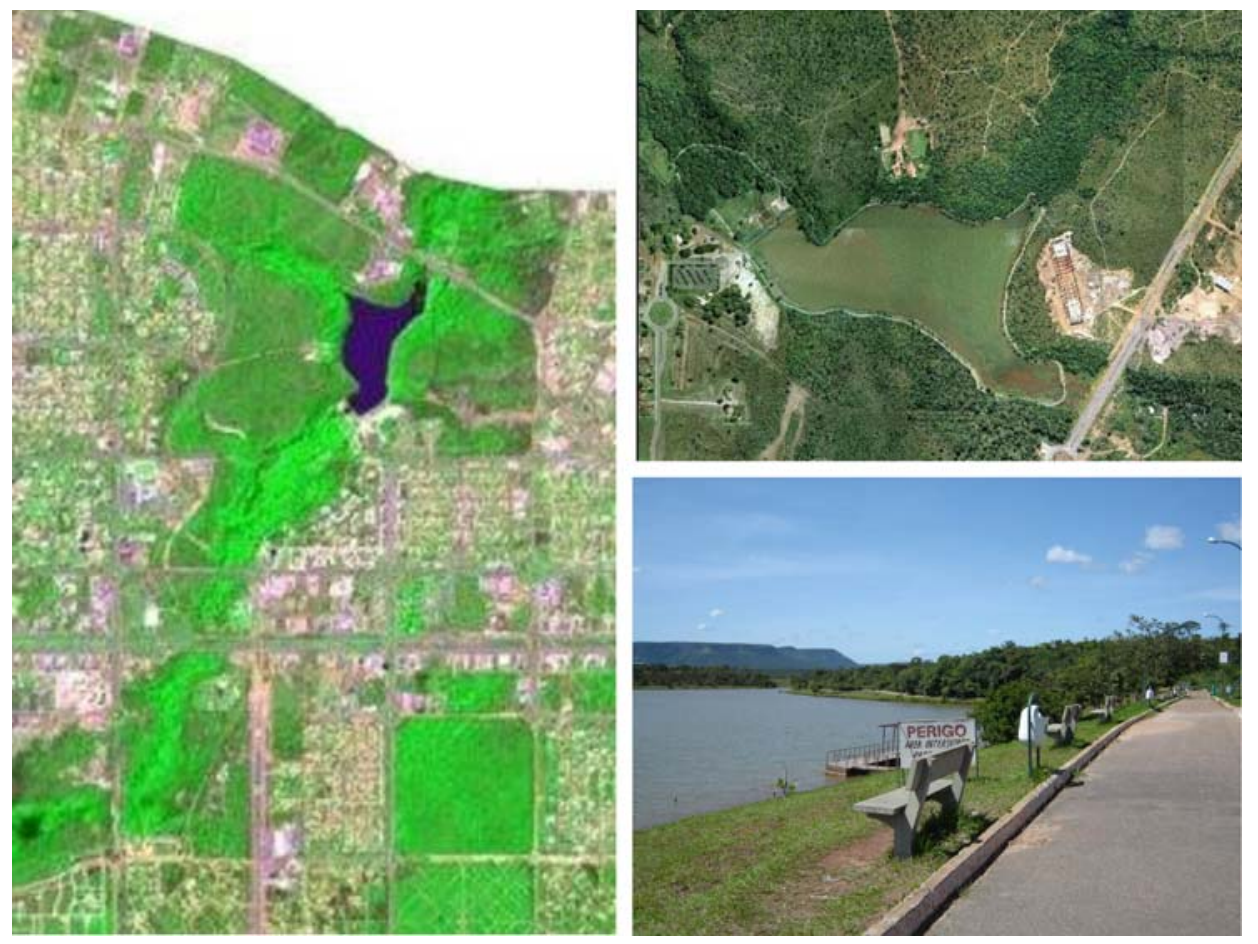

Fig. 47, Localização da cidade e projeto do Parque Cesamar, principal parque da cidade. (Fonte: SEDUH, 2005)

Se os girassóis plantados na praça principal deram o nome a ela e uma identidade a cidade, a devastação proporcionada pelas máquinas na Avenida Teotônio Segurado, representa o símbolo do capital sobre a natureza, capaz de eliminar uma memória natural em detrimento de uma imagem de modemidade. Esta, foi produzida através de um paisagismo similar na estética a outras cidades, importando uma aparência não condizente com o contexto regional do cerrado.

"Os corredores formados pelas ruas, rodovias e ferrovias estão entre os ma is signific ativos e extensos de todos os espaços livres urbanos. Como canais através dos quais as pessoas entram na cidade, saem e se movem no seu interior, eles influenciaram a maneira como a cidade é percebida pela primeira vez por um visitante, como é lembrada e como é vista no dia-a-dia pelas pessoas que ali moram." (SPIRN, 1995, p 207) 
A preferência por espécies exóticas, por extensos gramados bem cuidadose por espécies que apresentam dific uldade em sobreviver no clima seco da região, gera a prefeitura um ônus financeiro de grandes proporções. Nesta questão, a insustentabilidade não se restringe a o âmbito econômico, mas afeta diretamente o social.
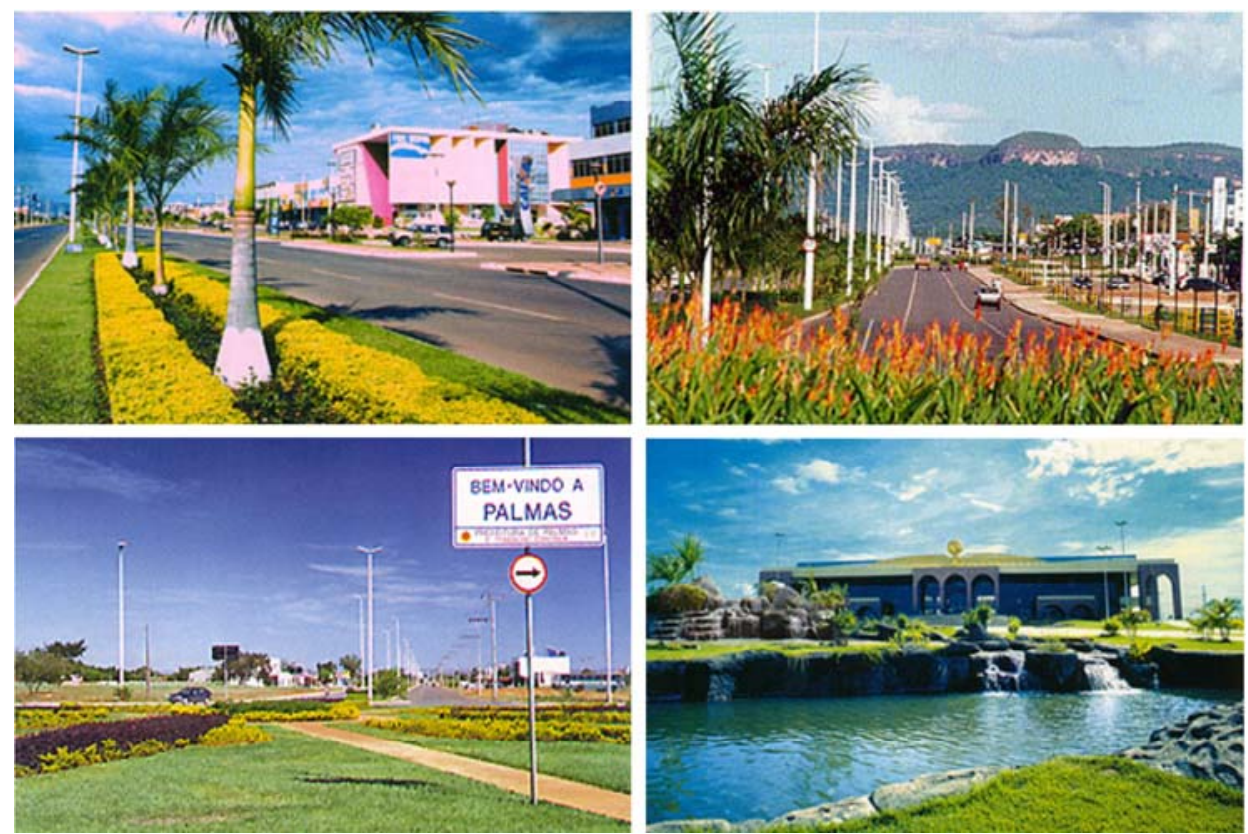

Fig. 48, Os jardins como ima gem da cidade. (Fonte: www.palmas.to.gov.br, 2005)

Os custos de manutenção dos jardins poderiam ser minimiza dos se as espécies nativas tivessem sido preservadas, e outras do cerrado tivessem sido preteriras pelos executores nos diversos espaços livres. Essa conseqüência pode ser vista nos meses secos, onde diariamente dezenas de caminhões regam durante o dia e a noite, os inúmeros canteiros e praças da cidade, dando a estes condições de sobreviver, e proporcionando uma imagem de cidade que cuida bem de seu patrimônio paisagístico.

O contexto urbano planejado de Palmas expõe as fragilidades e potencialidades da paisagem do cerrado. Estas devem inserir-se dentro de uma esfera cultural e ambiental própria, e de extrema importância para a arquitetura paisagística brasileira. A magnitude do projeto de uma nova cidade insere possibilidades de experimentação e elaboração de novos paradigmas e conceitos projetua is. 


\section{Do contexto a Iugar - Dimensões do Espaço Verde na Av. Teotônio Segurado}

A Avenida Teotônio Segurado é o limite entre o espaço natural de Palmas e a sua antropização, marco da ruptura entre o projeto e a paisagem natural do cerrado. Concebida para ser a principal via arterial da cidade no eixo norte-sul, dividindo ao meio a área do plano e projetando-se como futuro eixo do transporte coletivo de massa, esta se coloca também como um marco iconográfico e representativo da monumentalidade proposta para a nova capital. Tal magnitude pode ser percebida na sua extensão, 14 km, e pela largura de 150m, e pelo principal elemento de sua conforma ção, uma faixa de $45 \mathrm{~m}$ de espaço verde no meio da avenida.
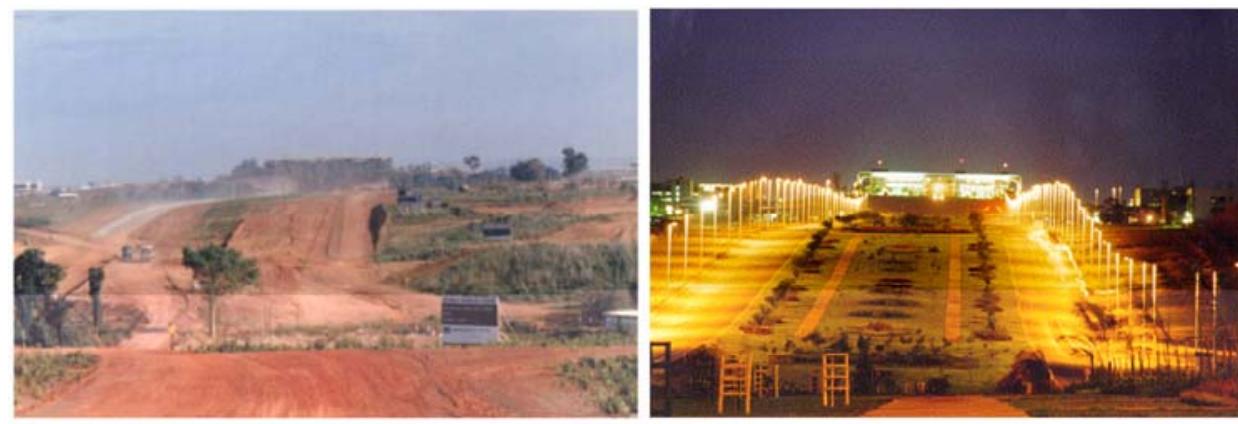

Fig. 49, Abertura da Avenida Teotônio. Canteiro Central da Teotônio sendo replantado com espécies não nativas. (Fonte: SEMUC ,2006; www.pa Imas.to.gov.br, 2005)

Esta poderia ser, além de um importante espaço utilitário, um importante local da esfera pública. A demubada inicial da vegetação nativa marcou os limites de sua confomação. Essa destruição da natureza foi contomada pelos gestores da cidade com uma estratégia de replantio dos canteiros da avenida, sendo plantadas ao longo de alguns trechos palmeiras imperia is nas laterais e diversas árvores e arbustos em seu interior, tudo isto envolto por uma forração de gramíneas que esteticamente constitui seu cenário paisa gístico.

As inúmeras críticas a esta intervenção não se dão somente pela qualidade do projeto, mas sim pelo contexto. Esta poderia ser um exemplo projetual em outra cidade, mas analisando a sua história, e as 
potencialidades de consolidação da paisagem local, gera uma discussão do rumo que a cidade deve tomar para a configuração de seus espaços verdes. A monumentalidade intencional também criou hiatos onde a ausência da vegetação serve para representar tal caracteństica, deixando junto a ela apenas um extenso gramado que possibilite a plena visão da praça e como conseqüência do Palácio Araguaia (Fig. 50).

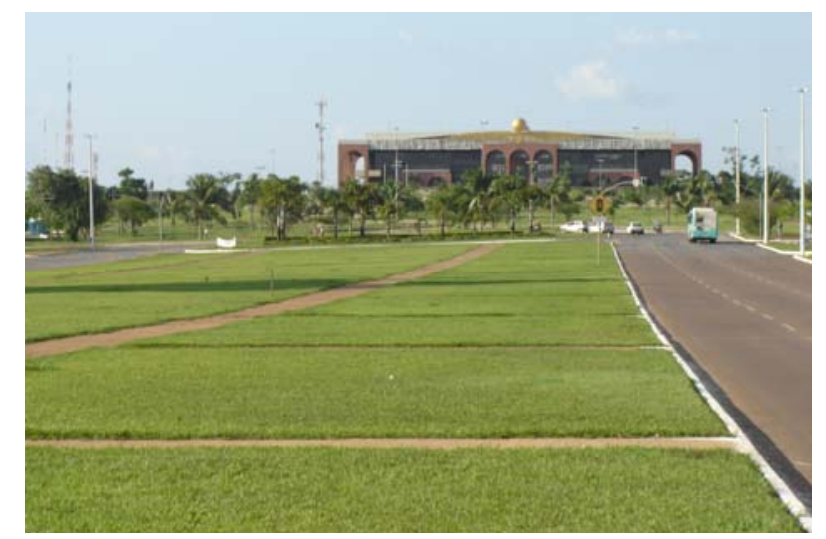

Fig. 50, Trecho da Avenida com o Palácio Araguaia ao Fundo. (Fonte: Autor, 2005)

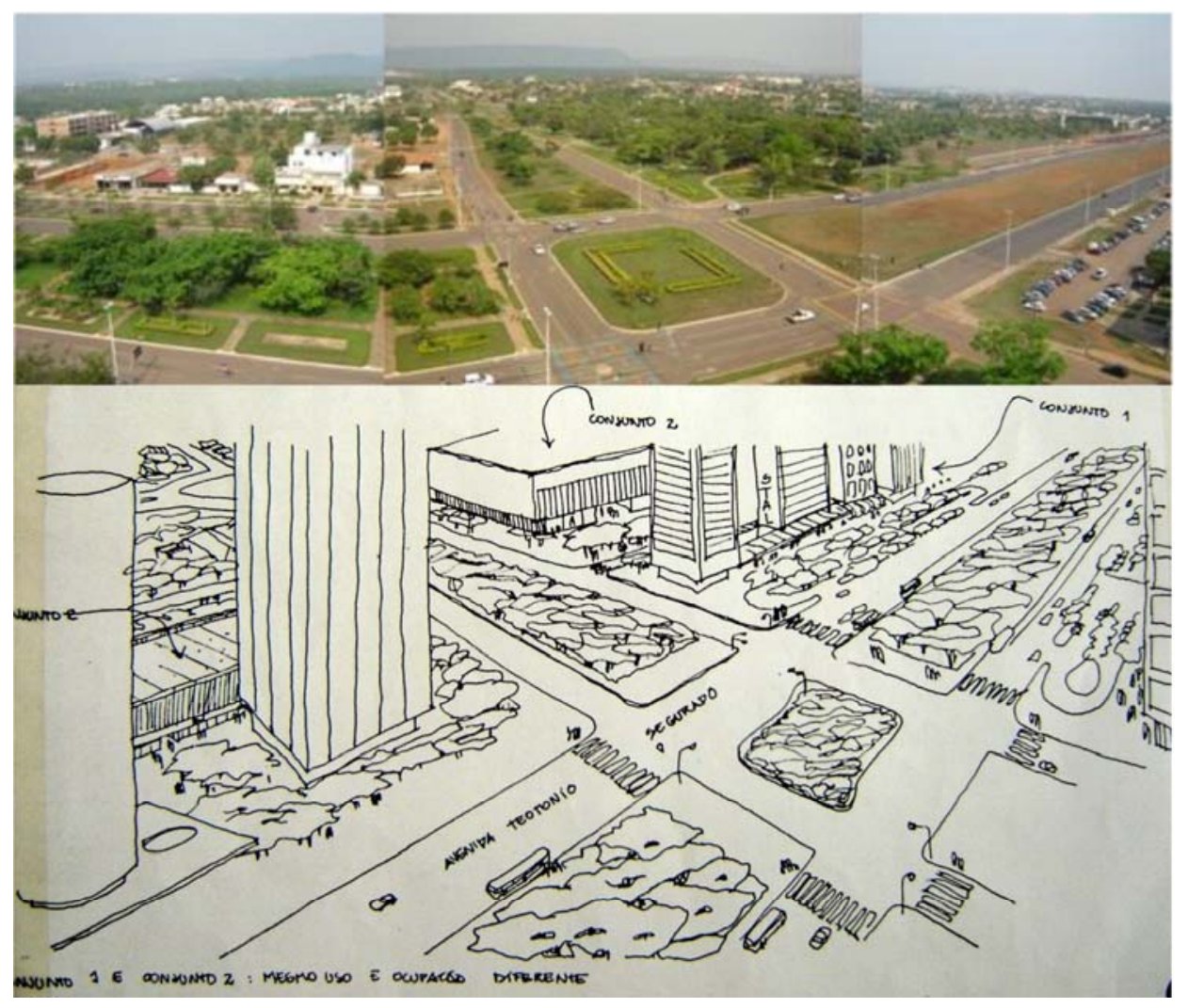

Fig. 51, Croqui do Grupo 4 ilustrando o contexto urbano e paisa gístico proposto para a avenida, e uma foto local. Percebe-se a intenção de se criarno canteiro um grande corredor verde. (Fonte: REVISTA PROJ ETO n 146, 1991) 
A duplicação da avenida até seu limite a o sul (2006), possibilitou uma nova discussão de como preservar a vegetação existente e utilizá-la como parte da construção espacial e cultural da paisagem. Grande parte da vegetação do canteiro central está sendo mantida para que os erros cometidos no passado não se repitam.

Ao longo desta, percebe-se as três diferentes categorias de apropriação dos espaços verdes em Palmas. A primeira se caracteriza nos trechos com intervenções paisa gísticas, onde após a retirada da vegetação natural, foram criados jardins e plantadas palmeiras e árvores, com o intuito de caracterizar esteticamente a avenida. Em parte esse objetivo foi alcançado, pois ela é um marco na paisagem, porém sem nenhuma riqueza cultural e espacial que consiga enfatizar uma apropriação efetiva da população.

\footnotetext{
"Para muitas pessoas, a natureza nas cidades significa árvores, arbustos e gramados nas ruas, parques e jardins particulares, mas essa s plantas são, na verdade, as menos "natura is" das comunidades vegeta is." (SPIRN, 1995, p 197)
}

Estes trechos foram desenhados para que a população pudesse usufruir de seus caminhos e ambientes com tratamento paisagístico, porém outro fator intensifica a ausência de atividades humanas. A falta de interfaces entre o espaço livre e o espaço edificado, resulta em uma desconexão entre o pedestre e a avenida, que apenas usufrui dos edifícios como se o contexto urbano não se fizesse presente.

A segunda categoria se destaca na construção de uma identidade paisagística para a cidade. Essa se evidencia por espaços onde a vegetação nativa foi incorporada a uma nova espacialização.

A terceira foma corresponde a locais onde a vegetação nativa foi parcialmente retirada e não teve intervenção projetual. Estas áreas são encontradas no recém inaugurado trecho sul da avenida, demonstrando o potencial desta vegetação. 
O cruzamento junto ao Bosque dos Pioneiros na Avenida Teotônio Segurado se destaca pela confluência dessas categorias. O bosque destaca-se na paisagem pela sua grande quantidade de árvores e por uma conformação espacial que a qualifica como um local de intensa apropriação humana. Próximo a este nó se localiza um canteiro que também foi totalmente devastado, porém sofreu tardiamente intervenção projetual.
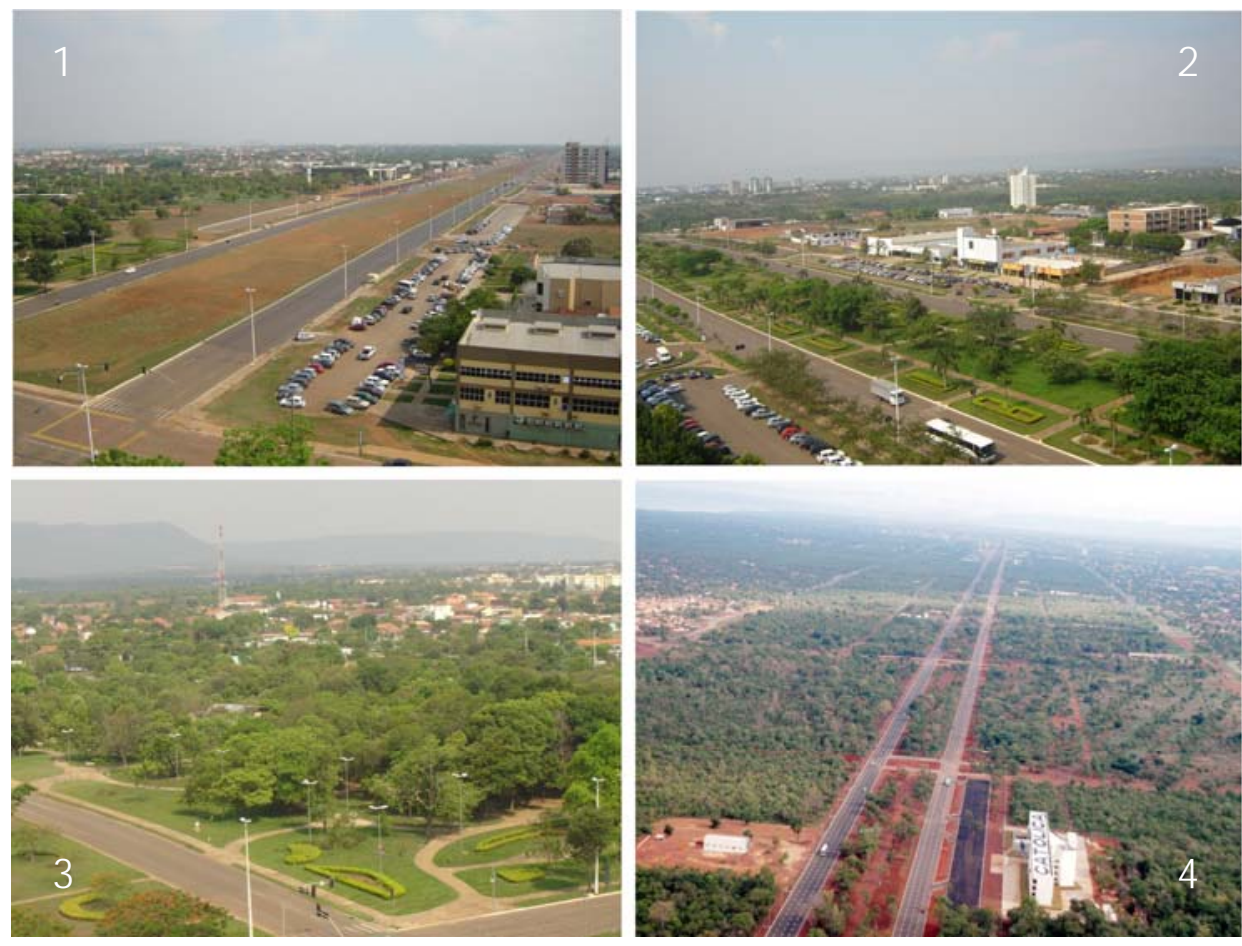

Fig. 52, Primeira foto: trecho totalmente devastado da avenida. Segunda: trec ho revegeta do, com as palmeira simperia is nas bordase caminhos na parte intema. Terceira: Bosque dos Pioneiros com árvores nativas incorporadas a o projeto pa isa gístico. Quarta: novo trecho da avenida com a preservação de espécies nativas. (Fonte: autor/ J omal Primeira Página, 2005)

Quando se tem uma percepção do contexto mais amplo desta paisagem, o quadro se agrava, compreendendo a irresponsabilidade ambiental dos construtores, e o grande potencial paisagístico perdido, caso tivesse sido mantida a vegetação nativa, proporcionando um outro cenário, menos desolador do que o atual. Estas três formas de espaços verdes se repetem pela cidade, moldando a paisagem e suas fomas de a propriação. 


\section{“A s invasões bá rbaras"}

Plano e a gestão nem sempre seguem as mesmas prioridades quando se trata de definir diretrizes de desenvolvimento de uma cidade. A experiência de Brasilia já demonstrava que construir uma nova cidade signific a va abrigar pessoa s originárias de todas as c lasses so c ia is e regiões do Brasil e isso causaria conflitos pela terra. Segundo Malheiros (2002) o govemado Estadual, indiscriminadamente, desapropriou teras em exagero, ultra passando em muito os limites da cidade, com a usura de colocá-las ao seu inteiro dispor, para depois fazer suas negociatas e seus a padrinhamentos polític os, colocando, assim, em "risco" e em complic ações juńdic as futuras, a propriedade e o uso do solo urbano na área de Capital.

Embora o projeto tivesse propósitos de integração social, distribuindo igualitariamente a infra-estrutura pela cidade, a prática de "varrer a sujeira para debaixo do tapete" tomou-se a principal prática segregacionista executada pelo estado.

\footnotetext{
“O projeto original da cidade está sendo todo desviado, comprometendo o futuro da capital e proporcionando um crescimento desordenado, que pode fazer de Palmas, uma capital completamente fora do Plano Diretor (...) estão acontecendo alguns erros até gritantes e ninguém toma providências no sentido de consertá-los." (J ORNAL DO TOCANTINS, 17 a 20, abril, 1989, p. 6, citado por URA, 1995)
}

Taquaralto foi o início da ocupação fora dos perímetros da cidade planejada. Atualmente, é a principal cidade satélite, uma alusão as de Brasília, com uma infra-estrutura urbana constituída, se consolidando como ponto de desenvolvimento industrial.

\footnotetext{
"As contradições extemas do Plano Diretor de Palmas dizem respeito às influências de Taquaralto e o processo de favelização oriundo do modelo e qualidade de habitação, construídos naquele distrito. A interferência de Taquaralto sobre o projeto de Palmas foi muito forte se observamos que o povoado se transformou num salto de um aglomerado de casas para um dos distritos mais populosos do Estado, num período de aproximadamente seis meses, a população de Taquaralto pulou de 300 habitantes para 20 mil habitantes.
} 
Enquanto Taquaralto inchava, se transformando em um bolsão de mão-de-obra barata a $18 \mathrm{~km}$ da capital." (URA, 1995)

Próximo a Taquaralto, os Jardins Aurenys, nome "carinhosamente" doado pelo então govemador Siqueira Campos para homenagear a sua esposa, foi o início do maior impacto ambiental e urbanístico causado ao plano de Palmas. O novo distrito ao sul ocupou uma área próxima a um fundo de vale, desprovida de infra-estrutura, e abrigando a população mais carente. O amparo do Estado veio a través de um lote, um pedaço de terra, uma parcela de sonho onde a infra-estrutura mínima necessária de habitabilidade não se fazia presente. Tal ocupação teve início em 1990, quando a cidade poderia abrigartodos esses moradores de forma humana e com qualidade, nas inúmeras quadras a serem abertas pelas empreiteiras que rasgavam o cerrado.

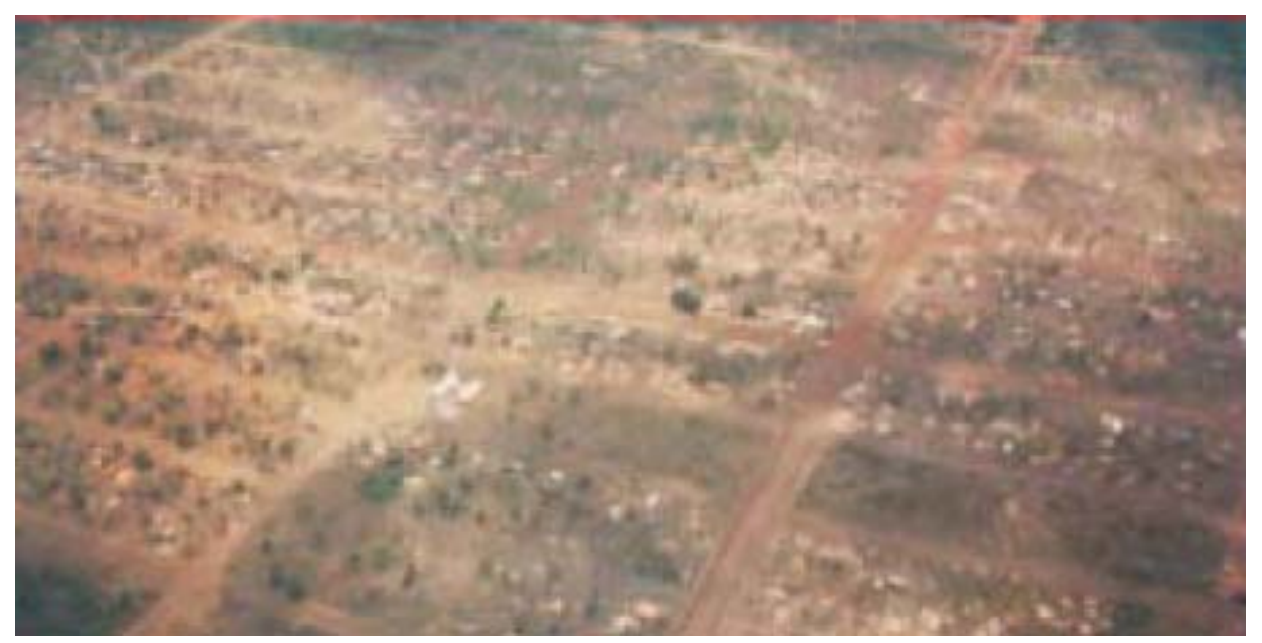

Fig. 53, Oc upação do J a rdim Aureny em 1994. (Fonte: IPUP, 2002)

Com a crescente ocupação nas áreas periféricas, a umenta a pressão por novas invasões só que em áreas ma is próximas ao centro. O processo de favelização da cidade foi se concretizando e se tomando um incômodo para a imagem de progresso e modemidade da nova capital, necessitando uma ação imediata do poder público. 


\section{Vila União: um bairrodentrodo plano}

A área prevista para ser a terceira fase de expansão da cidade foi designada para as pessoas que estavam às margens do desenvolvimento de Palmas. A excelente localização geográfica, no alto de uma colina com vista para a Serra e do futuro lago, somando-se a proximidade ao centro administrativo, fizeram dela alvo de cobiça tanto pela classe dominante, como pelos moradores que estavam instalados precariamente nas primeiras "favelas" da cidade.

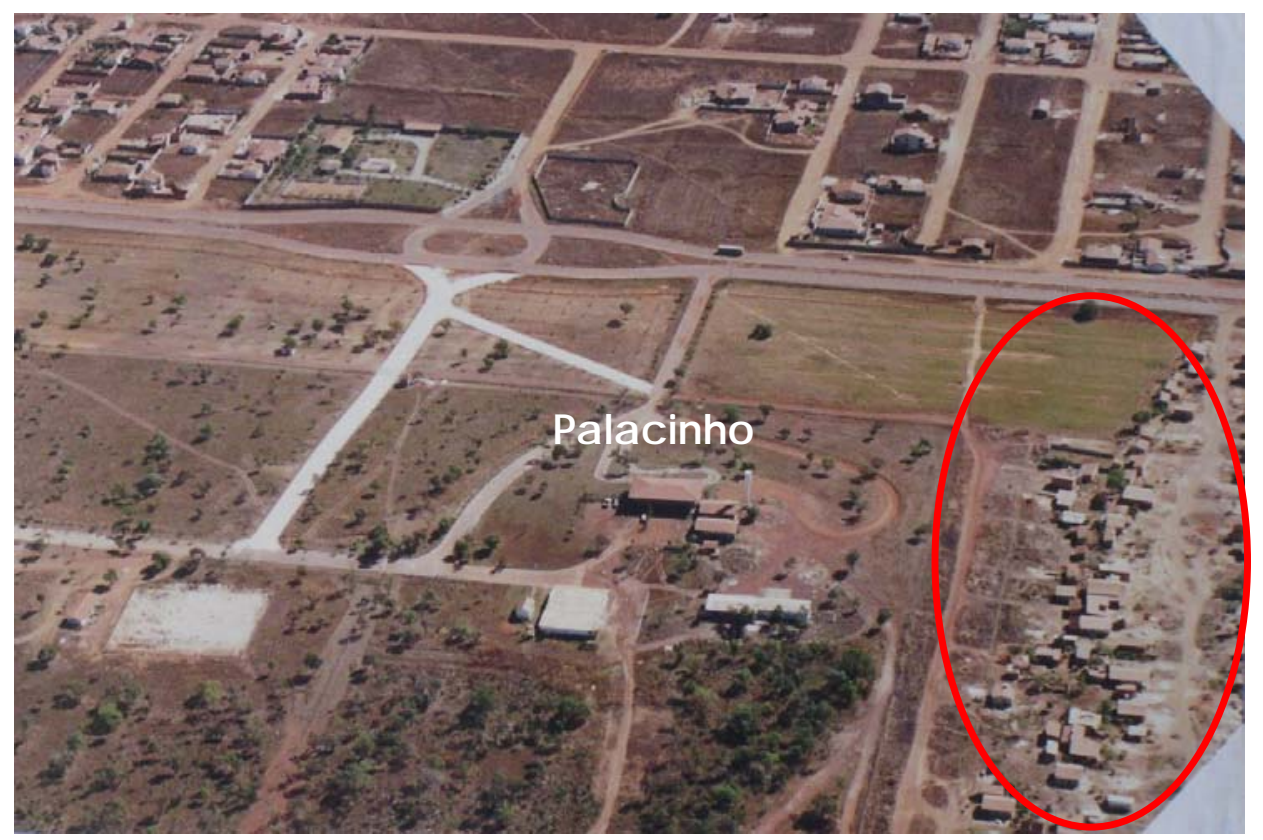

Fig. 54, Área do Palacinho no início de Palmas, sede temporária do govemo do Estado, com casas construídas irregula mente junto a ele. (Fonte: SEMUC, 2006)

A condição do seu sítio pemitiu uma rápida ação do govemo que de forma organizada incentivou a principal invasão de pessoas na área do plano. Essa ocupação conformou a Vila União, marco no crescimento e na forma de desenvolvimento do plano de Palmas. (Fig. 55)

Sua história tem início com a doação por comodato23, a políticos e personalidades influentes, dos lotes projetados pelo escritório Grupo 4, para as Amo 31, 32 e 33, doados pelo então Govemador Siqueira Campos em

\footnotetext{
${ }^{23}$ Comoda to: segundo o dicionário Aurélio, empréstimo gratuito de coisa não fungível, a qual deve ser restituída no tempo convencionado.
} 
1991. O Estado havia contratado o escritónio que planejou Palmas para o parcelamento das quadras, com lotes de 400 a $800 \mathrm{~m}^{2}$. O projeto foi feito e aprovado para ser executado ${ }^{24}$, porém os polític os a liados à base govemista não tiveram tempo de usufruir do bem doado. A decisão do recém eleito govemador Moisés Avelino, foi a de solucionar a crescente favelização e periferização que ocomia na nova capital a través de novos assentamentos.

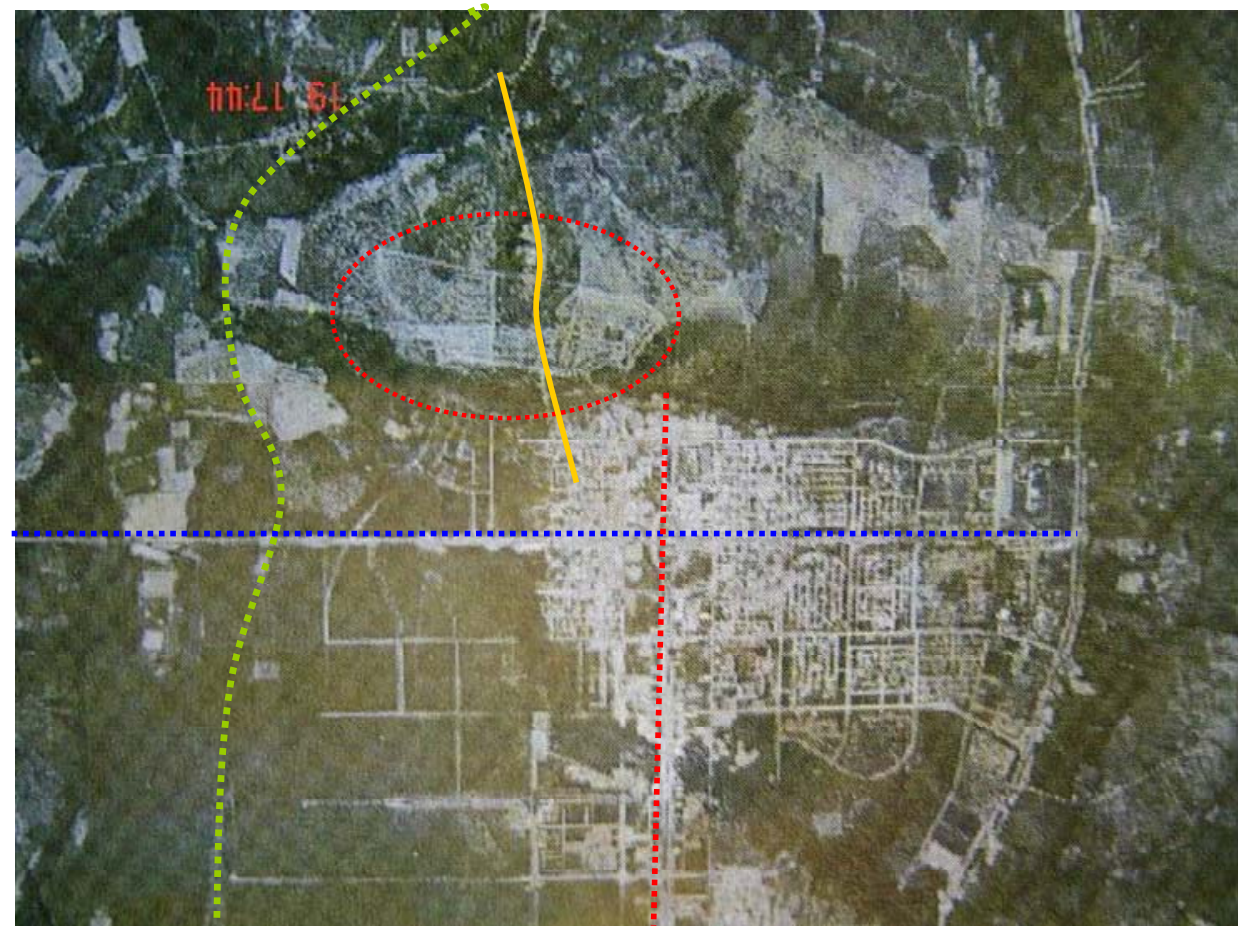

Fig. 55, Limites definid os pelo desenho. Em azul e vermelho as avenidas que formatam o traçado. Em verde o limites do lago. Em ama relo o antigo caminho que ligava a capital Miracema, anterior a Palmas, e que influenciou na decisão de ocupação da Vila União, em vermelho. (Fonte: SEDUH, 2006)

A Vila União é o único local dentro do setor planejado de Palmas que é denominado como bairro. A diferença não está somente na nomenclatura, que se confunde com as siglas numéric as, mas na identidade que se criou a través do processo de conformação de seu espaço urbano. A face de bairro, onde a paisagem se assemelha a de uma cidade tradicional, consolidou a região como uma das ma is emblemáticas da cidade.

$24 \mathrm{O}$ projeto original feito pelo Grupo 4 se perdeu nas consecutivas revisões do plano diretor, ficando a Agência de Desenvolvimento do Tocantins, responsá vel pelos projetos originais de cada Quadra. 
Segundo o govemador Avelino, responsável pela ocupação da Vila União, esta foi uma medida encontrada para alojar as pessoas que chegavam à cidade em busca de trabalho e se alojavam à beira dos córregos e em áreas de preservação sem nenhuma infra-estrutura urbana. A ocupação seguiu o projeto original, porém realizou modificações para adaptar uma população totalmente diferente da prevista pelo govemo anterior.
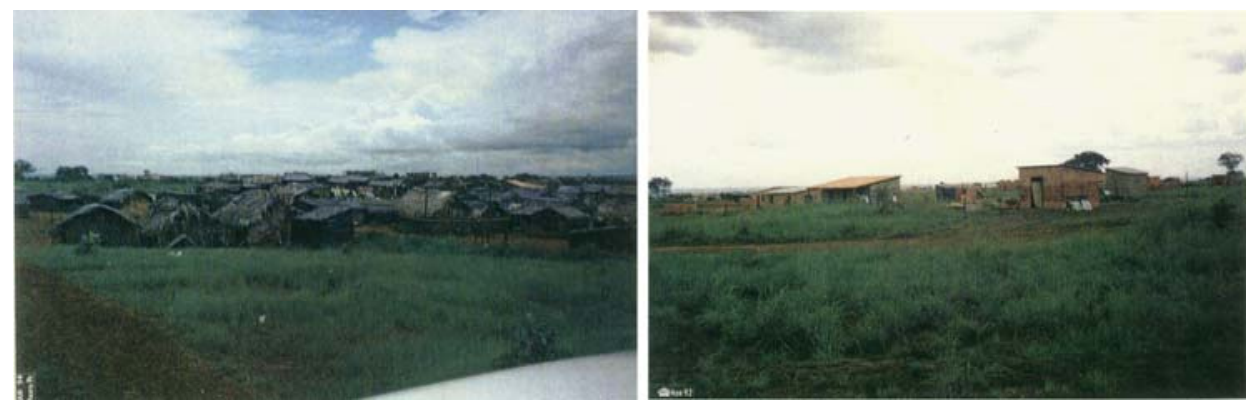

Fig. 56, Primeira s construções da Vila União. (Fonte: URA, 1995)

Este ato dito social sacramentou o fim da ordem de ocupação do temitónio de Palmas. As pessoas interessadas em receber um lote, recebiam senhas, e assim que sorteadas deveriam ocupar e pemanecer no lote. Os moradores inicialmente se instalaram de forma precária, em barracos de lona e sem infra-estrutura urbana, porém a posse em definitivo permitiu a melhoria das instalações. Essa foi promovida por ações dos govemos estadua is e munic ipa is, com programas habitaciona is e de autoconstrução.
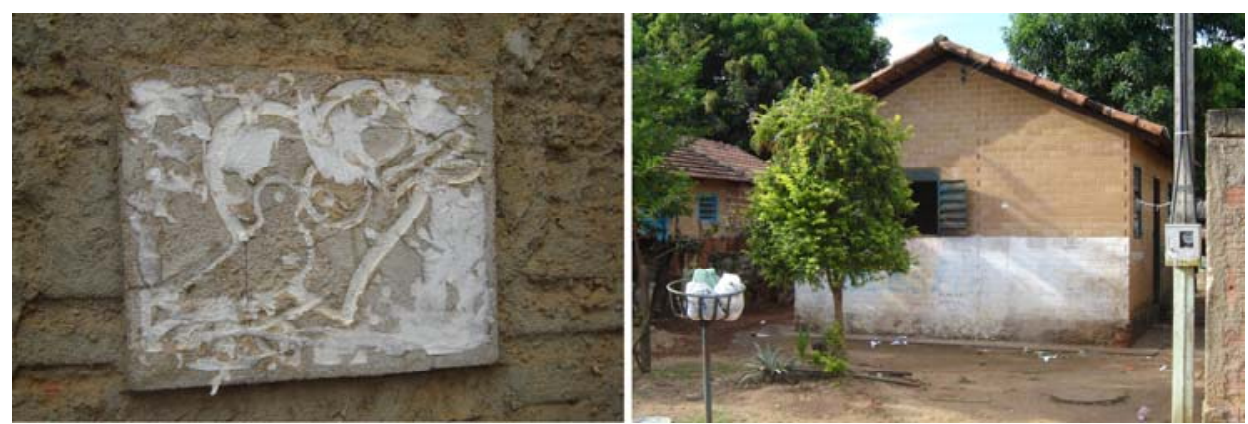

Fig. 57, Deta lhe de Casa com o logotipo do J oão de Barro, doada pelo estado, e casa com tijolo pré-fabricado, doada pela prefeitura. (Fonte: autor, 2007) 
A dificuldade inicial gerou a força comunitária que deteminou a forma de ocupação e transfomação do espaço nesta parcela da cidade. A imagem de local de invasão foi sendo substituída pela imagem de ser um dos loca is mais ricos em vida urbana. O seu centro comercial, os mercados, a praia, as praças e a feira, atraem moradores de diferentes áreas da cidade, produzindo uma importante centralidade urbana, desmistificando o papel do projeto deteminista como promotora de qualidade. A cidade que foi planejada e projetada se deparou diante de situações reais de problemas urbanos - a luta pela terra - implantando novos modelos de urbanização no espaço determinado.

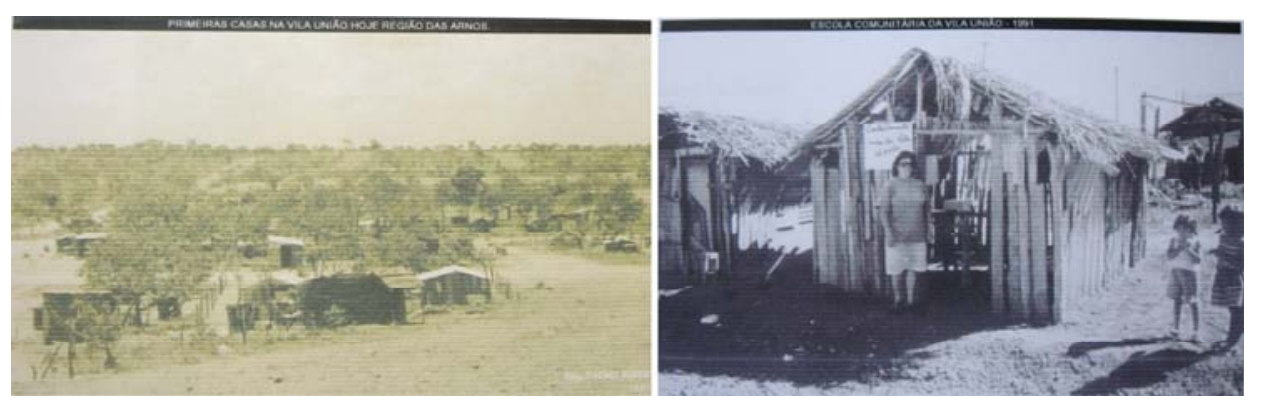

Fig. 58, Primeiras construções da Vila União. (Fonte: LRA, 1995, fotos: Thenes Pinto, 1991)

A Vila União hoje é uma cidade dentro de outra cidade. O traçado de Pa Imas se faz presente nos limites das quadras, com a estrutura viá ria e com o paisagismo dos canteiros centrais das avenidas, demarcando os limites entre o planejado e o espontâneo. É o limite entre a cidade que cresce seguindo padrões estéticos e a cidade que segue padrões culturais de desenvolvimento.

As quadras que inicialmente foram ocupadas, Amo 31 e 33, atualmente $303 \mathrm{~N}$ e $307 \mathrm{~N}$, seguiram parcialmente o desenho original desenhado pelo escritório Grupo 4 antes da invasão, porém foram feitas adaptações ao projeto, na tentativa de ordenar o crescimento e legitimar os lotes nas quadras. Por ser tratar de uma área de baixa renda familiar, o parcelamento priorizou a ocupação com lotes unifamiliares e menores do que os padrões das outras quadras, provocando assim uma rápida ocupação e um maioradensamento. 

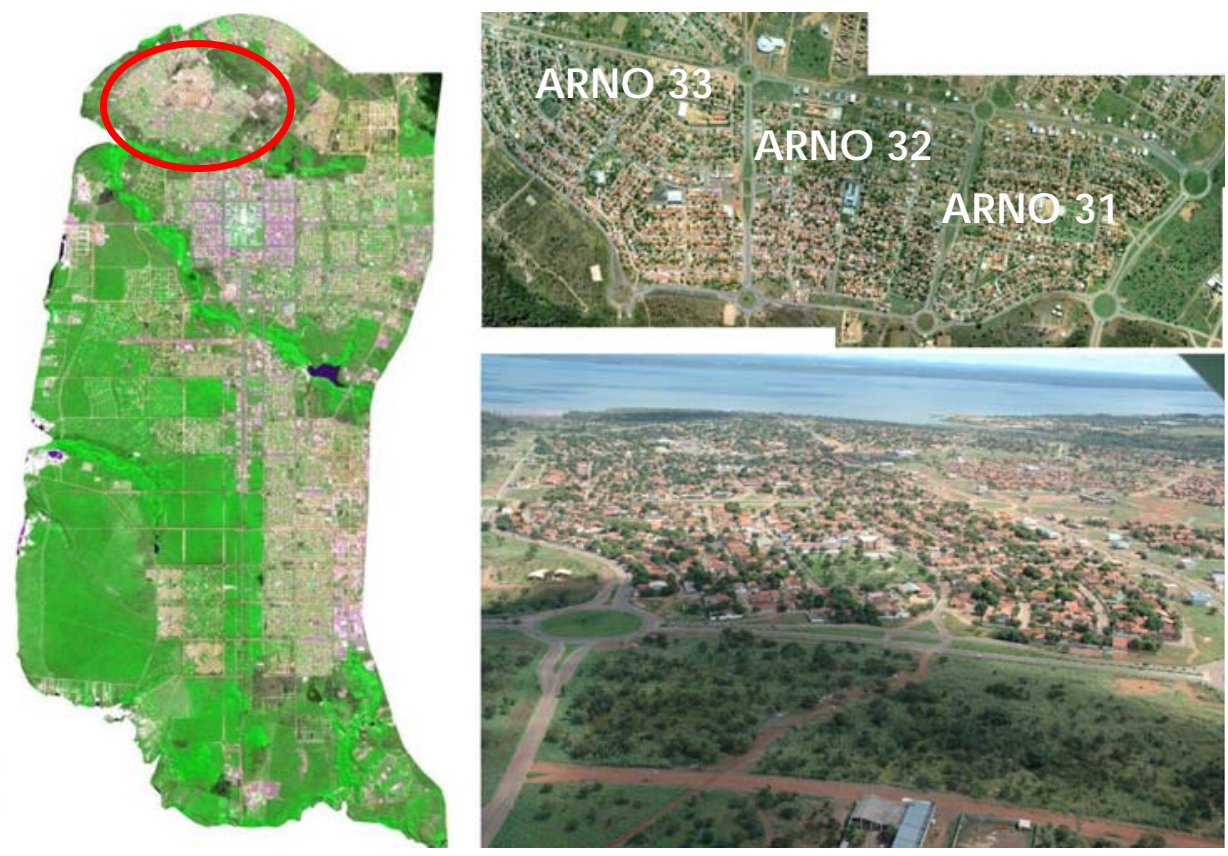

Fig. 59, Plano de Palmase detalhe das três quadras que compõem a Vila União. (Fonte: SEDUH, 2006)

A terceira quadra da Vila União, a Amo 32, atual 305N, foi desenhada seguindo alguns princípios "ecológicos". Projetada pelo arquiteto Luís Femando Miranda, da Secretaria de Infra-estrutura do Estado, ela continha alguns elementos que a diferenciava das outras. Esta iniciativa tinha como principal objetivo legitimar e unificar morfologicamente a área invadida à "legal", sem diferenças no desenho e nos índices de uso propostos pelo plano diretor. Porém, ma is uma vez, a cidade real emerge como contra ste à cidade ideal, apresentando as diferenças de apropriação que contrapõem o determinismo do projeto.

O conceito original da cidade, de que diferentes classes poderiam coexistir no mesmo espaço foi estancado à medida que as quadras começavam a se identificar como guetos de grupos sociais. A Vila União, por muito tempo serviu de locus para pessoas marginalizadas à nova sociedade que se criava. Embora a segregação ocorra, nova diversidade resultou de diferentes culturas regiona is que se instalaram na cidade.

$\mathrm{Na}$ Vila União, a diversidade se alia à espontaneidade com que os espaços foram configurados. Os processos socia is e a gestão deste espaço, promoveram uma força comunitária que se evidencia na sua conformação. 
As dificuldades e as conquistas ao longo do tempo acarretaram na transfomação do "acampamento" inicial, em uma região rica em interações entre o social e o urbano. O resultado é uma esfera urbana própria, onde a dimensão cultural, os ritos, os hábitos e as necessidades são revelados a tra vés do espaço público. ${ }^{25}$

Alguns aspectos de cidade tradicional de destacam na Vila União. Quem circula por suas ruas, quem observa seu comércio parece estar em uma cidade do interior do Tocantins, Pará ou Maranhão, estados de origem da maioria de seus moradores. Esse fato não se deve ao desenho das quadras, ou ao projeto de Palmas, mas a contraposição ao zoneamento ńgido proposto por estes. Ela é o contraponto entre o concebido e o vivido, entre o plano e as variáveis benéficas que incidem sobre a produção do espaço urbano, e é uma resposta aos modelos urba nístic os funciona listas e pragmátic os que a inda persistem nas práticas do urba nismo.

\section{Quando a praça vira mercado e o mercado vira praça}

As áreas comercia is em Pa lmas têm um papel decisivo nos limites entre a modemidade e os costumes tradicionais que formam o seu ambiente urbano. São neles que as diferenças aparecem e expressam a diversidade necessária para a construção da identidade do espaço, onde diferentes práticas cotidianas são incorporadas rapidamente a seu espaço público. Os pontos de concentração de comércio geram a atratividade necessária

\footnotetext{
25 Em entrevista concedida, as representantes da Associação de Moradores da Vila União, Dalva, Neuza e Cissa, relataram a história da Vila União e a história de cada uma delas. Vivenciar esse processo de conformação espacial, pemitiu um olhar diferenciado dos atores que participaram da ocupação, caracterizando essa história a través da percepção de uma luta contínua pela qualidade de vida, resultando em práticas que confrontaram as premissas do plano como reguladoras dessa qualidade. Desde a abertura das ruas, instalação da rede água, até a construção das praças, resultou de ações comunitárias que visando à melhoria do espaço urbano das quadras, e assim da condição cidadã perante a cidade. A memória viva destes acontecimentos eleva a condição partic ipa tiva de seu processo de conformação, inscrevendo no espaço memórias, histónias, lutas e principalmente fatos do cotidiano que em outras situações poderiam passar despercebido, mas que adquirem um outro papel perante a legitimidade com que a esfera públic a é transformada. (entrevista concedida em 27 de outubro de 2006)
} 
para parte da vitalidade do espaço urbano. É assim em Taquaralto, em alguns pontos da região sul e no centro do plano. Na Vila União, o comércio é o principal articulador da espacialização criada pela espontaneidade promovida pela ocupação. Dentre essas, uma se destaca como o “coração" da Vila União, a feira da Amo 33.

"A maior parte dos usos da diversidade...Depende direta ou indiretamente da presença de um comércio urbano abundante, oportuno e diversific ado." (J ACOBS, 2000, p 162)

As feiras são em Palmas não só uma opção comercial, mas marcos da esfera pública dos moradores. Elas são os pontos de encontro de grande parte da população, assim como uma opção de lazer e cultura, de serviço e entretenimento. Várias feiras ocorrem em diferentes pontos, com destaque para as feiras da $304 \mathrm{~S}$ e da $307 \mathrm{~N}$, dois contrapontos no espaço em Palmas, a primeira na parte mais desenvolvida e rica da cidade, e a outra na Vila União.
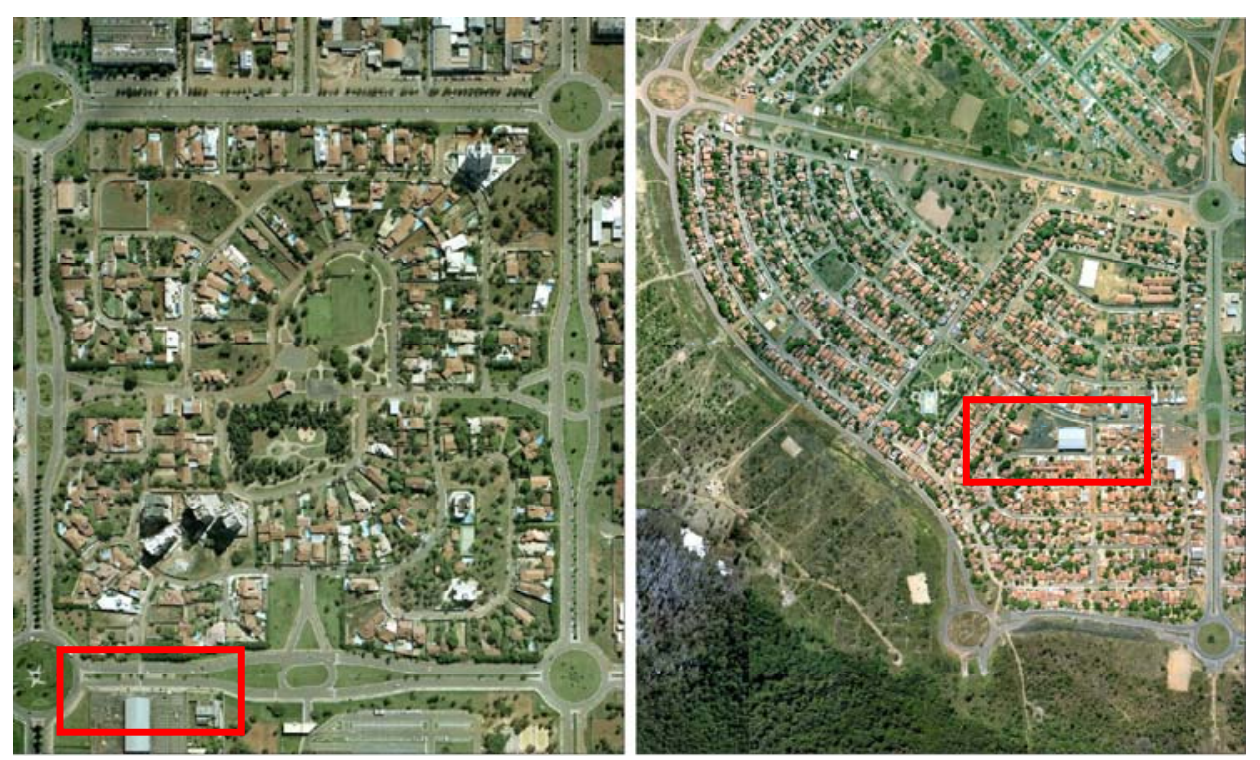

Fig. 60, Loca lização das Feiras 304S (AESE 31) e 307N(ARNO 33). Na primeira foto a feira se insere em uma área especial, fora da quadra residencial, mostrando a funcionalidade do espaço, enquanto na Vila União ele está inserida no meio da quadra. (Fonte: SEDUH, 2006)

As estruturas físicas são similares, uma cobertura metálica que demarca o espaço e a paisagem. Os feirantes e os produtos também são 
praticamente os mesmos, porém, há uma diferença entre elas, na Vila União se localiza no meio da quadra, junto à rua de maior fluxo.

A Área Pública Municipal $n^{\circ} 10$ da Amo 33(307N) seria inicialmente destinada à construção de uma igreja e de uma praça junto a ela. A forma de ocupação da quadra promoveu uma alteração decisiva. A instalação de pequenos estabelecimentos comerciais próximos à feira, promoveu a mudança de uso do seu entomo. Esta alteração remete a função do espaço do mercado nos espaço livres das cidades históricas, onde o comércio de mercadorias caracterizava o espaço da troca e a fomação da urbe. A implantação deste equipamento no local fez com que esta se tomasse uma centralidade espacial não só para a quadra, mas para a Vila União como um todo.

A feira se tomou o principal atrativo para o comércio local, que mesmo na ausência desta nos dias úteis da semana, insere na paisagem um imaginário de cidade real que faz com que haja vitalidade no ambiente urbano. A sua posição em meio ao tecido urbano e não localizado em algum setor determinado para esta função, como a Feira da 304S, localizada em uma Área de Equipamento (AE), fezcom que a integração na morfologia física da quadra ocorresse de forma positiva para o uso do espaço público.

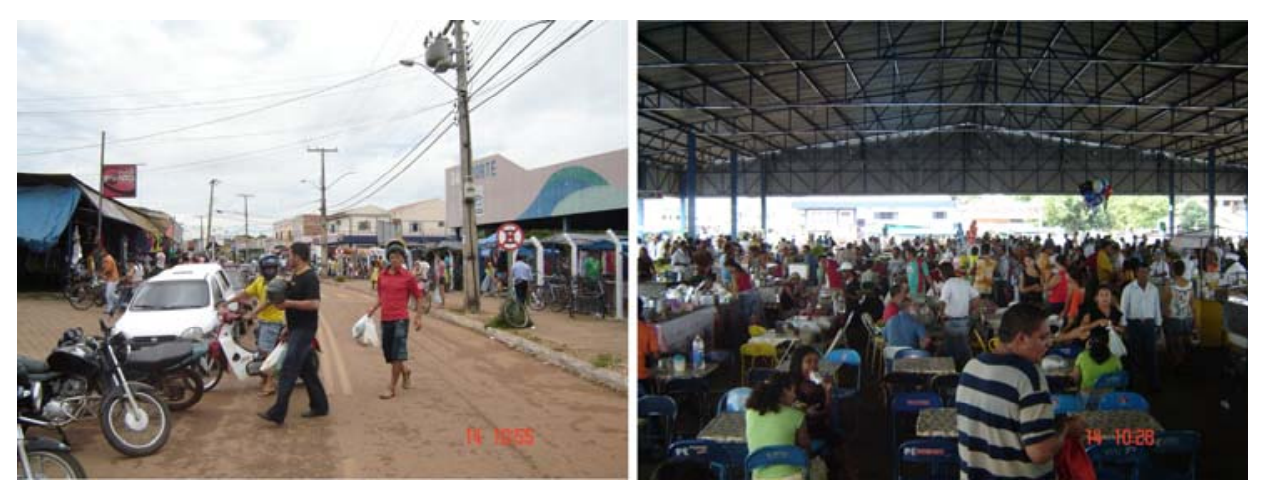

Fig. 61, Cenas do Mercado da 307N em uma manhã de domingo. (Fonte: autor, 2006)

A conformação do espaço evidenciou os processos culturais que o legitimaram como um lugar. A incorporação de uma nova ordem espacial traduz as necessidades rea is de sua sociedade, onde os processos cultura is 
geram locais com urbanidade. A fomatação destes recriou os espaços do cotidiano, inserindo uma nova dinâmica urbana entre osloca is do comércio, de lazere da moradia.

O espaço do mercado é a representação das conquistas da população para o uso público. Na Vila União o comércio está voltado para a quadra e não de costas como acontece nas demais, enfatizando o caráter simbólico do espaço das trocas, do mercado e da vida comunitária, marco de uma sociedade ainda em formação.

Este processo permitiu a criação de um senso de pertencimento em seus moradores. Há uma relação direta entre este, esfera pública e conformação de lugares. A coletividade está no cotidiano e no hábito de cada morador, na exposição da vida pessoal no âmbito público, na forma como ocorre a apropriação dos espaços livres em cada parte da cidade. Para Carlos, a identidade e sentido de pertencimento se ligam aos lugares habitados, marcados na história pela presença, pela acumulação cultural. (1996, p 30)

Os espaços públicos da Vila União trazem signific ados produzidos pelo processo de ocupação, inscrevendo os traços de uma memória de luta e conquistas, que pode ser verificada na arquitetura, nas praças, nos espaços públicos e na conformação desta paisagem. Os símbolos da cidade planejada não foram impressos em um primeiro momento nesta história, tomando a consolidação de seu contexto urbano atual uma conquista diária, promovida pela “união" dosmoradores.

O simplesfato de ser conhecida por uma denominação própria, e não somente por siglas que se perdem nas inúmeras promovidas pelo projeto, ARSE 32, ARNO 41, ACNE 10, ALAMEDA 08 e NS-1026, a mpliam o sentimento de identitário dos moradores da Vila União. Essa nomenclatura por números faz com que os moradores da cidade não reconheçam as quadras e avenidas arteriais, sendo necessários marcos para identificar alguma localidade.

26 As siglas caracterizam a distribuição de funções pelas quadras da cidade, direcionando o uso principal de cada uma. As avenidase as ruasta mbém são ca rac teriza das por siglas. 
As ruas da Vila União representam a imagem de sua vitalida de urbana. Pessoas nas portas das casas ainda vêem a vida passar, as crianças sentem segurança em jogar futebol ou brincar nas estreitas ruas, e alimentam o senso comunitário através de simples atos cotidianos. A rua se coloca como dimensão concreta da espa cialidade das relações socia is num determina do momento histórico, revelando nos gestos, olhares e rostos, as pistas das diferenças sócias. (CARLOS, 1996, p 86)

Os ciclistas se amontoam nas alamedas num balé constante e que simboliza sua realidade econômica. O alto custo do transporte público faz com que boa parte dosmoradoresutilize a bicicleta para se deslocarpara o trabalho, escola e comércio. Essa prática que poderia ter uma conotação ecológica para alguns, refere-se à incorporação de valorescultura is.

\begin{abstract}
"A enância, multiplicada e reunida pela cidade, faz dela uma imensa experiência social da privação de lugar-uma experiência, é verdade, esfarelada em deportações inumeráveis e ínfimas (deslocamentos e caminhadas), compensada pelas relações e os cruzamentos desses êxodos que se entrelaçam, criando um tecido urbano, e posta sob o signo do que deveria ser, enfim, o lugar, mas é apenas um nome, a Cidade." (CERTEAU, 1996, p 183)
\end{abstract}

A grande quantidade de pessoas que se apropriam do espaço público faz da rua o grande palco do cotidiano na Vila União, da diversidade, desde desempregados nos bares até os religiosos que se aglomeram em frente às inúmeras igrejas para exaltar a fé, ampliando o significa do de espaço democrátic o que este apresenta.
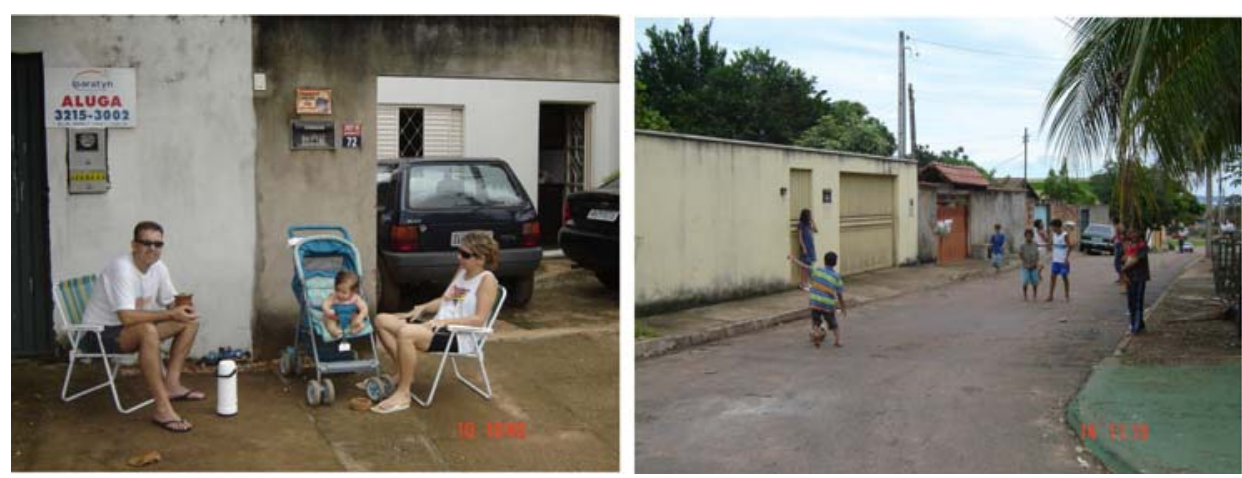

Fig. 62, Cenas do cotidiano nas ruas da Vila União. (Fonte: a utor, 2006) 
Se o espaço público da Vila União se caracteriza por uma experiência democrática, cidadã, isso ocorre principalmente pelo contraponto ao projeto na sua construção. Seus limites se evidenciam não como uma ba reira, mas com uma potencialidade de inscrever as dimensões cultura is existentes no processo de conformação deste lugar. 


\section{As c ategorias de análise}

O objetivo deste capítulo é demonstrar as categorias que definem o conceito de urbanidade proposto para este trabalho. A análise segue as definições apresentadas no capítulo 02, parametrizadas pelos valores aferidos pelos limites dos projetos urbanos das unidades de vizinhança. A escolha destas se deve ao fato de apresentarem uma maior evidência nas interfaces entre os limites do projeto urbano e as diferentes práticas sociais de apropriação do espaço, que constituem e conformam lugares em meio a uma cidade planejada.

A estrutura de questionamento colocada até aqui, com a hipótese central - os lugares conformados nos limites entre o projeto urbano e os processos sociais, são os principais promotores da urbanidade - delimita as categorias de a nálise, dentre outras possíveis, para confrontar as duas áreas elencadas como objeto deste estudo, e assim demonstrar os graus de urbanidade na construção do espaço livre de Palmas.

A macro categoria deste trabalho é o espaço livre urbano e suas relações. Esta se divide em duas formas de avaliação: a primeira refere-se à uma condição qua lita tiva (a djetiva), sinaliza da pelas subcategorias múltipla centralidade e conectividade; enquanto a segunda se refere a uma condição formal (substantiva), na avaliação dos movimento e pemanência no espaço, relação entre espaço livre e construído, interface e espaço verde. Para a análise foram coletados dados primários e secundários das duas áreas escolhidas, em órgãos públicos e setores responsáveis pelo planejamento da cidade, realizadas observações in loco e entrevistas com representantes das duas áreas, com os planejadores da cidade e pessoas ligadas a história da cidade. Cada uma foi analisada seguindo valores específicos e confrontada entre as duas áreas, e posteriomente correlacionada entre as diferentes categorias para a sistema tização do grau de urbanidade em cada área objeto de estudo. 


\section{Fragmentos de uma cidade real}

O macro-parcelamento de Palmas delimitou cada unidade de vizinhança pelo traçado viário, e definiu que estas deveriam seguir igua litariamente os princípios elencados pelo plano, porém com condições espaciais diferenciadas e com identidade própria. A expectativa inicial é que cada quadra fosse projetada por diferentes arquitetos de prestígio profissional, porém o único que participou ativamente desse processo foi o escritório de Arquitetura e Urbanismo Ruy Othake, projetando as principais quadras centrais de Pa Imas. Algumas foram projetadas pelo escritónio Grupo 4, enquanto outras por arquitetos contratados pelo Estado.

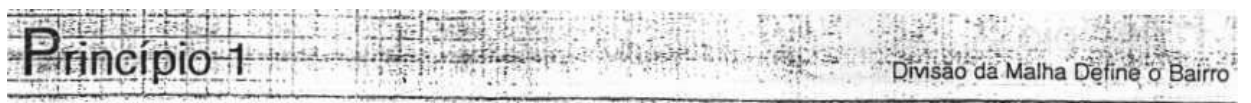

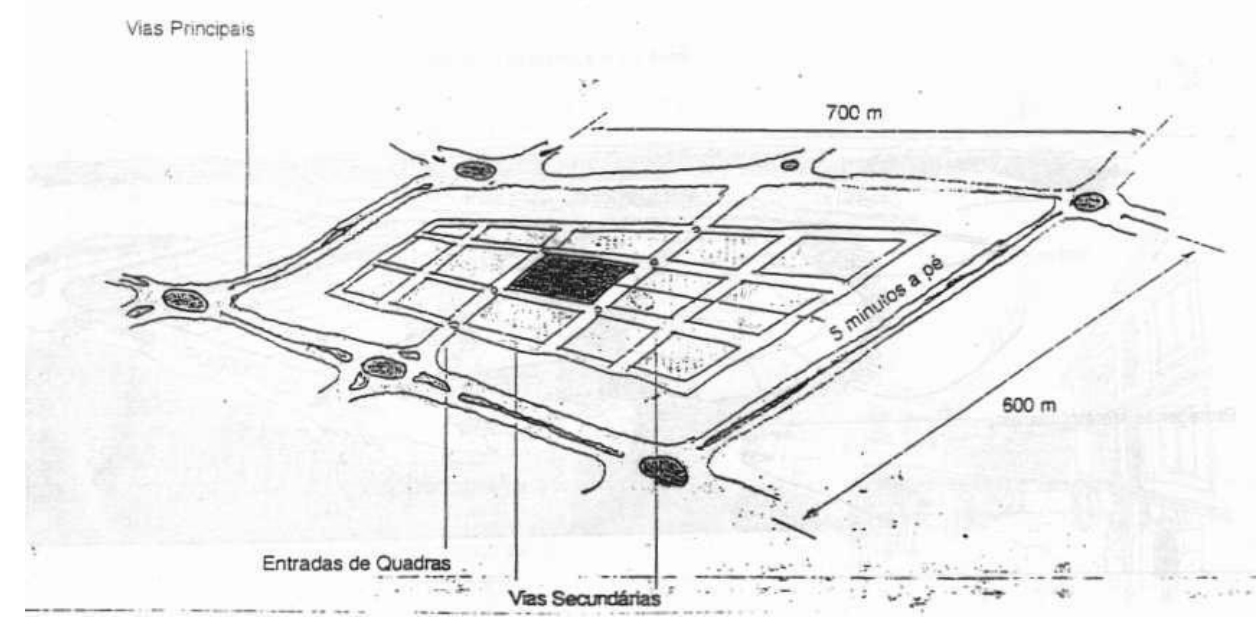

Fig. 63, Princípio de divisão da malha das quadras com seus acessos. (Fonte: Memorial do Projeto de Palmas, 1990)

Cada quadra representa uma parcela da totalidade temitorial do plano. O espaço fragmentado também pode ser fragmentánio, conformando vazios urbanos e proporcionando uma segregação espacial prejudicial à urbanidade. $O$ desordenamento inicial promovido pelo Estado resultou na abertura de inúmeras quadras sem que as já construídas 
estivessem parcia Imente ocupadas, como previa as fases de crescimento do plano.

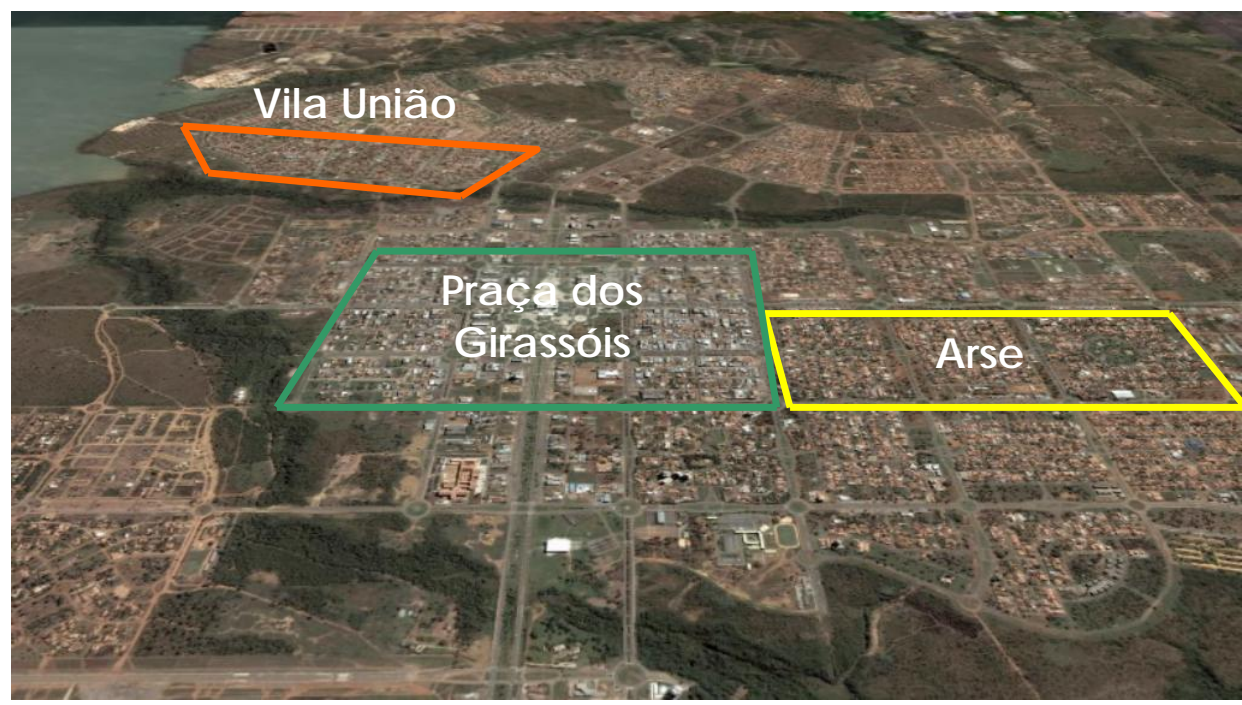

Fig. 64, Loca liza ção da Vila União e Quadras Centra is: proximida de a o centro. (Fonte: GOOGLE EARTH, 2007)

O resultado é a baixa densidade das quadras centrais da cidade, onde a especulação imobiliária esteve mais presente, e uma maior densidade nas quadras periféricas da cidade. Muitas ainda a presentam um grande potencial para ocupação, que por um lado cria novas possibilidades, mas que por outro, promove uma obsolescência e gera hiatos na conformação do espaço urbano da cidade.

As duas regiões objeto deste estudo são fragmentos desse processo. Duas á reas distintas, a primeira concebida pela força comunitá ria e a outra, pela força do projeto. Ambas apresentam infra-estruturas consolidadas, porém, o processo de conformação determinou as principais diferenças entre elas. As três quadras da Vila União atualmente evidenciam os limites do projeto para a conformação de lugares, inserindo na paisagem elementos da apropriação que marcaram a sua ocupação teritorial. A antiga "invasão", com barracos e instalações improvisadas, atingiu uma condição urbana diferenciada em Palmas As três quadras centrais, duas projetadas por Ruy Othake, revelam como os condicionantes do projeto possibilitam ou não a geração de urbanidade. 


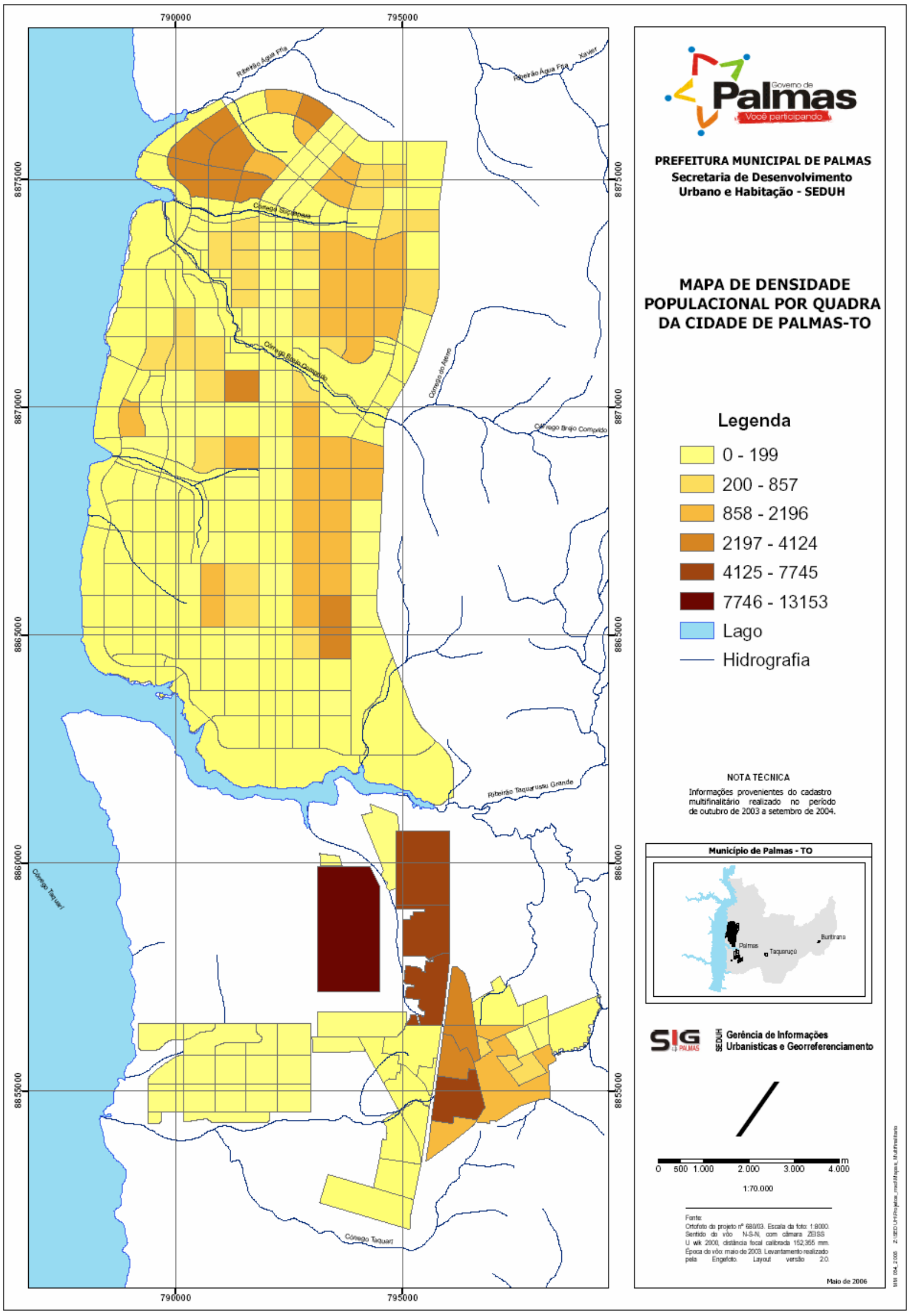

Fig. 65, Mapa de Densida de Populacional de Palmas. (Fonte: SEDUH, 2007) 


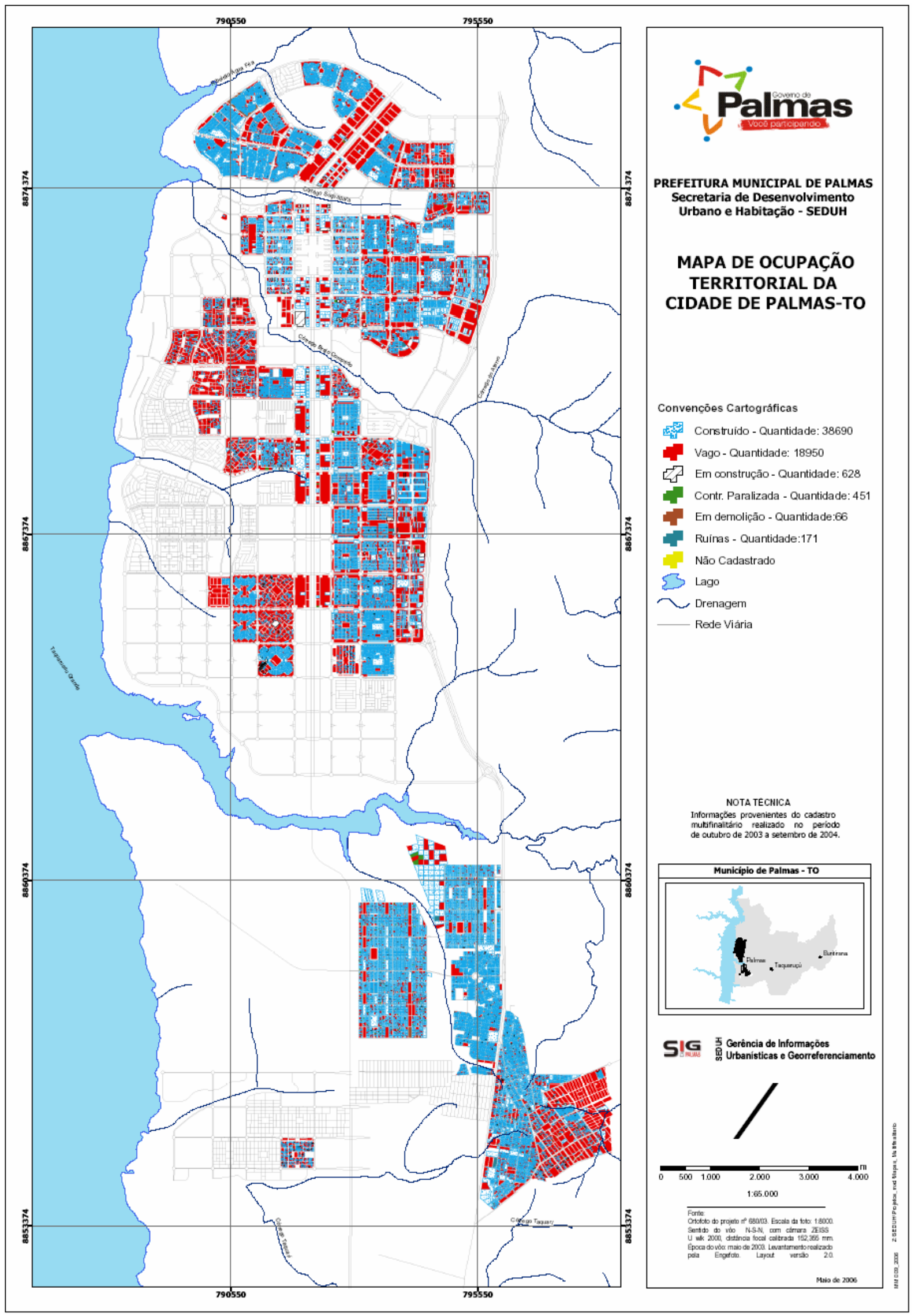

Fig. 66, Mapa de ocupação Teritorial da Cidade de Palmas. (Fonte: SEDUH, 2007) 
A ocupação teritorial de Palmas revela uma ruptura entre o concebido e o constituído. As quadras da Vila União inscrevem esse processo de forma ainda mais incisiva, caracterizando não só a força comunitária, mas as interfaces existentes entre sociedade e espaço. Seu projeto urbano foi estabelecido antes da ocupação, e como já mencionado, foi alterado para abrigar a demanda de pessoas que se instalaram. No parcelamento das quadras, prevaleceram lotes residenciais unifamiliares, diferenciando-se das demais quadras da cidade, que apresenta m lotes multifa milia res para garantir a sua densida de ideal.

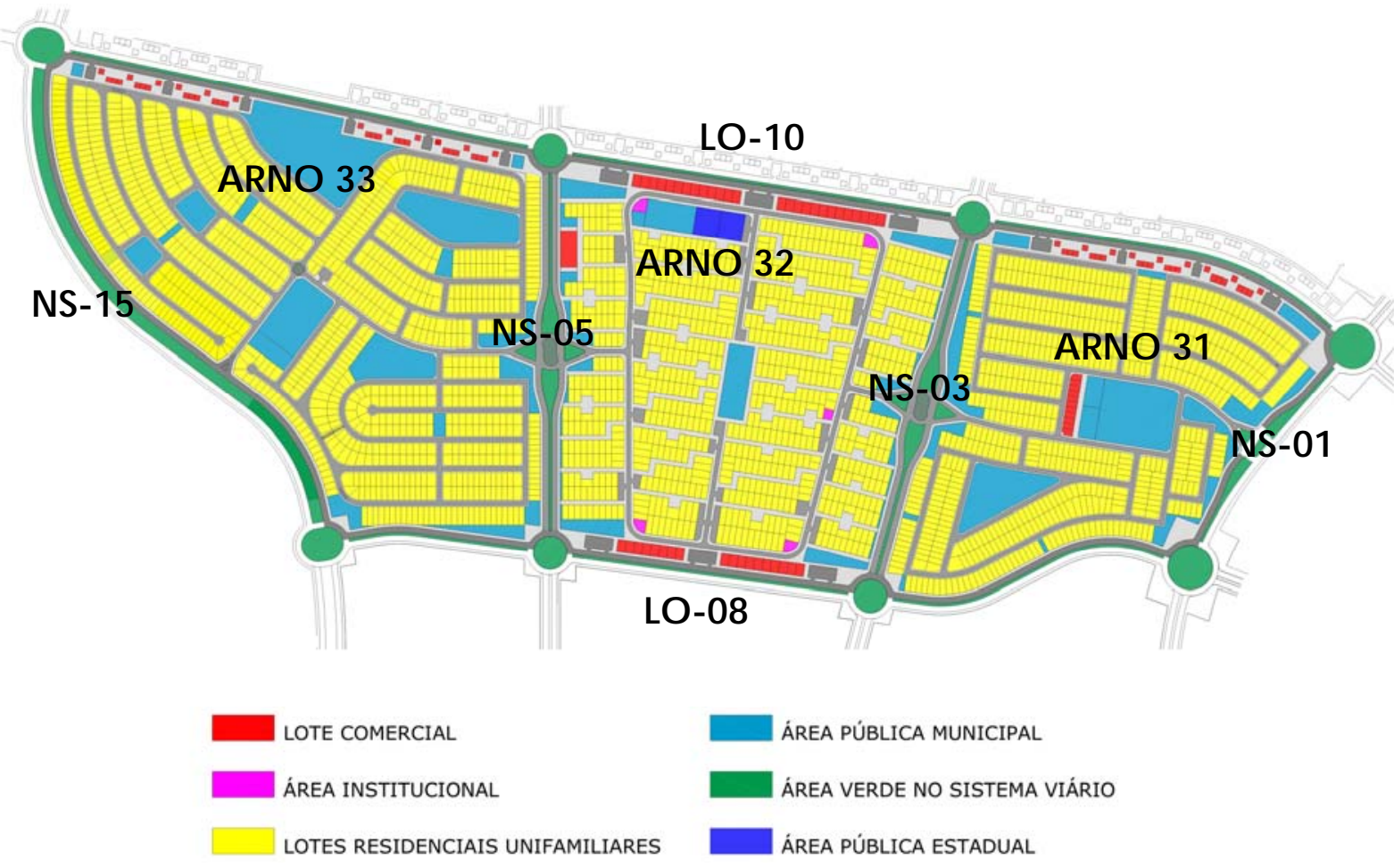

Fig. 67, Mapa de uso proposto para a Vila União. (Fonte: autor, 2006)

A Amo 31(303N) é a porta de entrada da Vila União. É o ponto de ligação com a Avenida NS-01 que liga todo o setor noroeste ao centro da cidade. Por sua localização estratégica, os fluxos no interior da quadra se intensific aram com o seu crescimento, sendo o principal trajeto de pedestres e ciclistas que saem ou entram na região. Por este fato a alameda que liga as duas entradas da quadra teve seu uso modificado à medida que a 
concentração e fluxo de pessoas aumentavam. A fig. 67 representa a proposta cadastral, que consta como aprovada pela prefeitura.

O mesmo padrão de desenho foi implantado na Amo 33 (307N), onde a topografia e oscondicionantes natura is proporciona ram um parcela mento urbano com ruas sinuosas e uma grande quantidade de áreas públicas municipais (APM). Esta é a única quadra que adotou cul-de-sacs como solução para o traçado urbano. Igualmente à Amo 31, o comércio vicinal, junto a Avenida LO-10, em vermelho na Fig. 67, apresenta um desenho diferenciado das outras quadras de Palmas. Os lotes comercia is não são contínuos e nem seqüenciados, mas formam um "movimento" nas edific ações. Por este fato, as áreas de estacionamento que costumam ficar localiza das em frente a os lotes na regiã o central, foram dispostas na sla tera is.

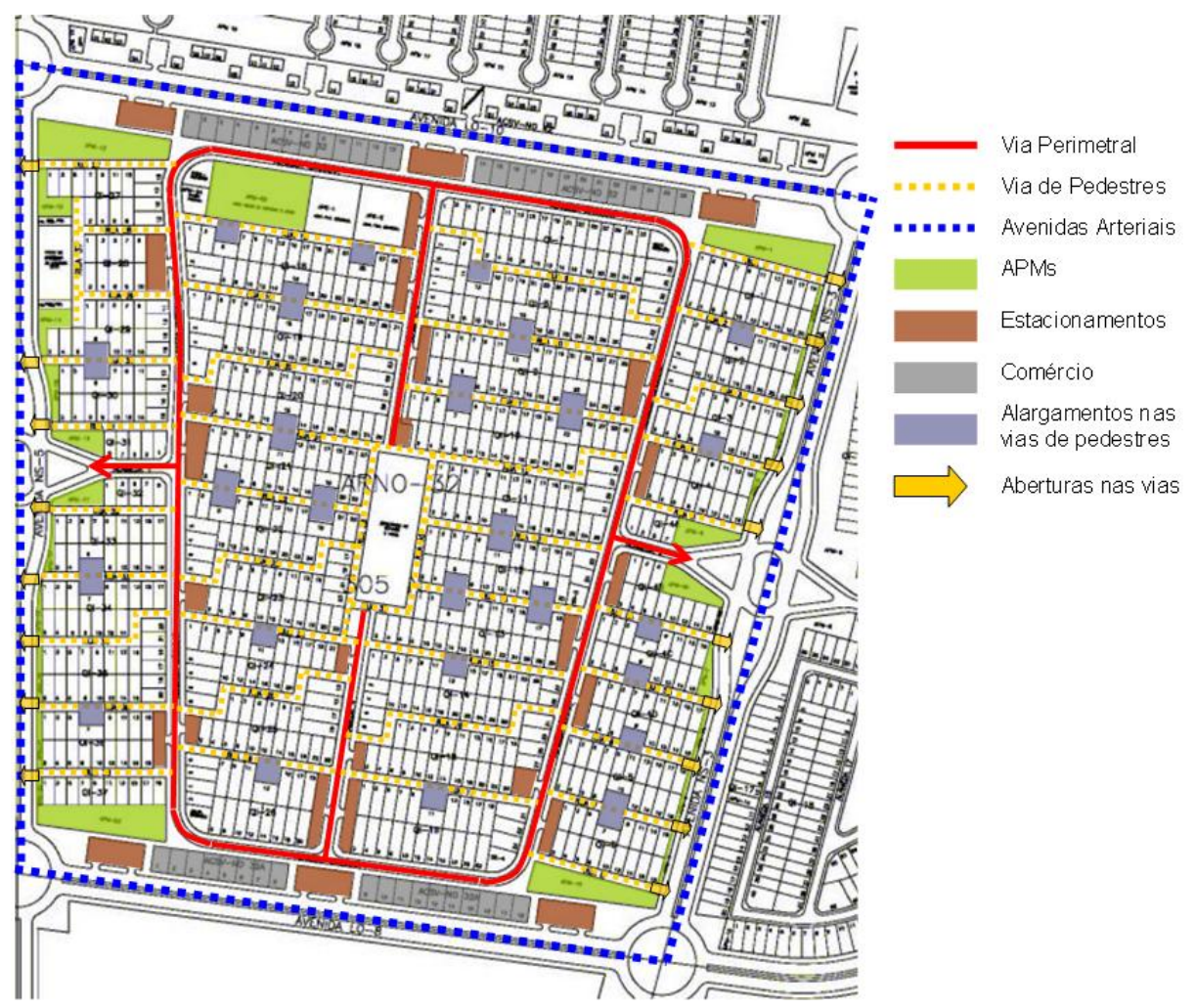

Fig. 68, Projeto diferenciado para a ARNO 32. (Fonte: a utor, 2006)

Deslocada deste contexto, a Amo 32 apresenta um desenho diferenciado na Vila União (Fig. 68). Embora o projeto trouxesse mudanças significativas, a apropriação dos moradores alterou o seu conceito original, assemelhando-se na paisagem e nas formas estruturais às outras duas 
quadras, o que permite uma legibilidade similar de seu contexto urbano. Como a vila União é vista como um todo, as diferenças se diluem na percepção dos moradores, que só identificam as quadras pelos limites que o sistema viário as impõem. No projeto, os a cessos à quadra e as ruas intemas, seguiram padrões convencionais, com dois lados destinados às entradas, restando aos outros dois serem espaços para o comércio vicinal.

O desenho quis incorporar uma visão ecológica que estava emergindo nas discussões do urbanismo contemporâneo. A proposta previa que os moradores pudessem deixar seus veículos em estacionamentos junto à avenida perimetral e ir caminhando até a sua casa, servida por um caminho de pedestres. Estes teriam um alargamento, um "respiro", proporcionado pela ausência de lotes em alguns trechos, formando pequenas praças (Fig. 68). A idéia de tirar o carro em uma cidade feita para ele, não foi bem aceita pela comunidade local, que via nas ruas tradiciona is um simbolismo igual ao restante da cidade.

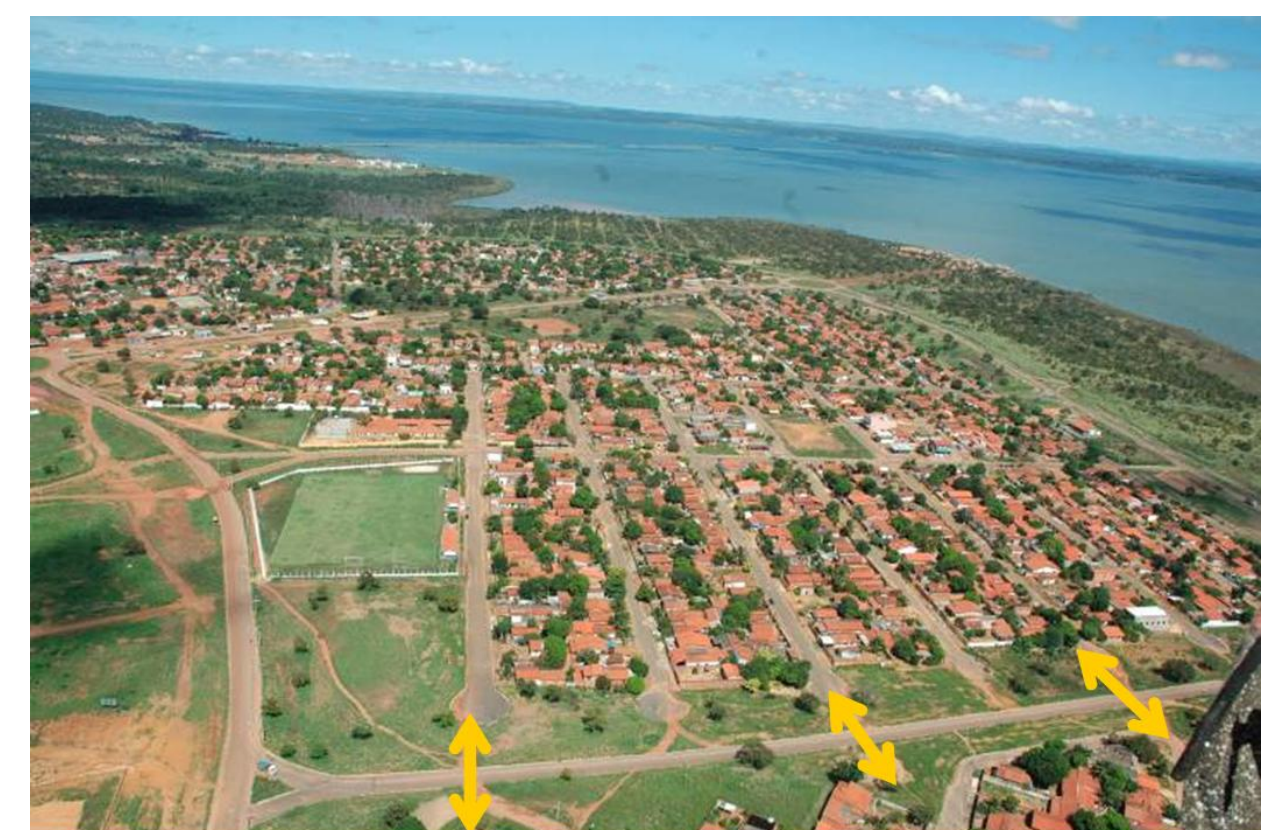

Fig. 69, Quadra de Palmas com marcas impressas no espaço. (Fonte: Reyffer Augusto, 2005)

A liberdade do traçado intemo se depara com seus limites, proporcionando enclaves no sistema de espaços livres de Palmas. Não é incomum observar caminhos nas gramas, guias quebradas, e conversões 
proibidas, realizadas por motocicletas e até carros, em caminhos de pedestres (Fig. 69). A dinâmica que surgiu com a necessidade de fluxos pela cidade é muitas vezes restringida pelo desenho.

A Fig. 70 representa como se dá o uso e ocupação da Vila União na atualidade. A principal alteração está na grande presença de lotes comercia is nos loca is destinados a lotes residenciais. No caso da Amo 32, os calçadões que seriam para circulação de pedestres viraram ruas para automóveis. Essa nova condição trouxe uma outra dimensão para o espaço e para a sintaxe urbana da quadra. Jane Jacobs em seus textos nunca exaltou o carro, mas tinha consciência do que ele representa para sua vitalidade. Ter ruas que chegam às avenidas, aumentou a sua permeabilidade, e com isso às opções de tráfego, não se restringindo às entra da s ofic ia is.

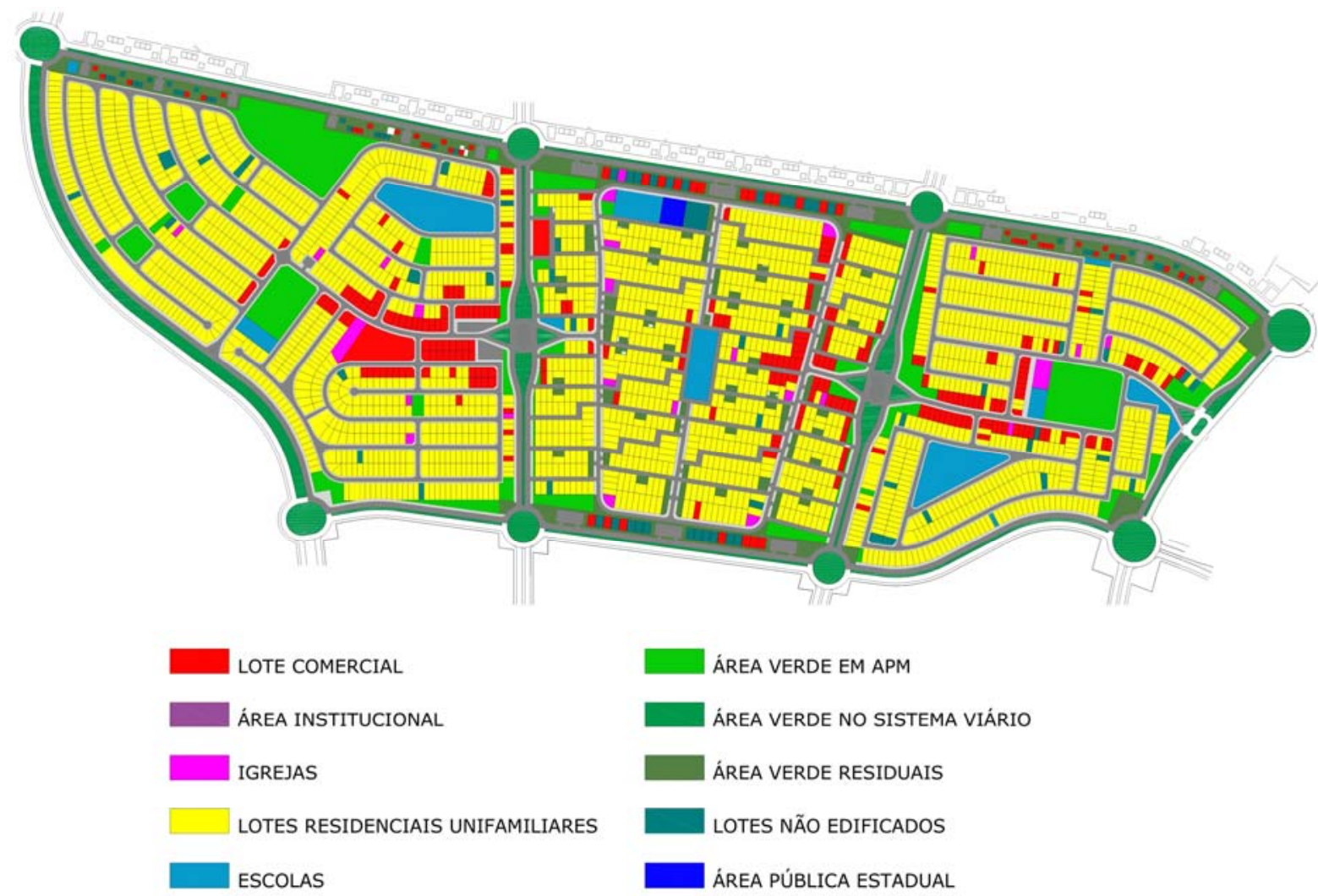

Fig. 70, Vila União seguindo as premissas de sua conformação. (Fonte: autor, 2006)

A malha urbana da quadra se integrou à paisagem de forma espontânea. J unto a essas "esquinas" surgiram lojas, bares, restaurantes e 
outros pequenos comércios com a intenção de atender aos moradores que por ali circulam. Com o crescimento espontâneo, a área destinada ao comércio vicinal, que deveria suprir a demanda do dia-a-dia, ficou destina da a usos mais específic os. Essa nova permeabilidade fez surgir pólos de atração dentro e fora da quadra. Apesar de manter o parcelamento inicial, os calçadões e as áreas destinadas a estacionamentos, sofreram transformações no uso e na morfologia.

Os alargamentos das calçadas foram incorporados aos lotes, e os estacionamentos são atualmente focos de disputa fundiária. Esse conjunto de áreas públicas é objeto de discussão da prefeitura e da associação de moradores. Parte da população almeja a incorporação de projetos de praças nestes locais, enquanto outra deseja que essas áreas sejam incomoradas no parcelamento fundiário da quadra, aumentando a oferta de lotes na região com a maior densidade de Palmas. Às margens desta discussão, estes são utilizados pela população de variadas fomas, mas principalmente para manifestações coletivas, sejam para jogos, reuniões, ou até mesmo atividades cultura is e religiosas.

O comércio às margens da Avenida NS-03 (Fig. 67), entre a Amo $31 \mathrm{e}$ 32, que a rigor não deveria existir, contrapõem o plano e se configura como uma cidade tradicional, com ruas, avenidas, comércios e residências se conectando na paisagem. Como há diversidade, o seu uso é constante, funcionando durante o dia e principalmente à noite, quando no fim de tarde as sorveterias, bares e restaurantes, começam a colocar mesas e cadeiras nas calçadas, delimitando cada um, o seu espaço em área pública, e atraindo parte dos moradores do bairro. A permeabilidade desta é fundamental para integrar o espaço urbano, unindo as três quadras em um bloco único.

Essa conexão se dá também pelo comércio, que se concentra nos acessos e não nos limites viários, proporcionando uma leitura diferenciada do espaço. Nas outras quadras de Palmas esses são somente canteiros ajardinados servindo como porta is de entrada. Essa diferença insere uma 
percepção de um lugar que se fez não como símbolo da nova capital, mas como símbolo das necessida des humanas.

Essa ocupação alimenta o uso do espaço público através de um contexto urbano diferenciado. Outros exemplos nesta quadra podem ser citados, como a área da APM-3, originalmente destinada a uma pequena praça, foi transformada pela Associação de Moradores de Vila União e com convênio firmado com a Ruraltins, em uma horta comunitária que beneficia parte da população local. A ação comunitária sempre foi uma característica desta região, conseguindo no decorrer de sua história dar a legitimidade que o bairro necessitava.

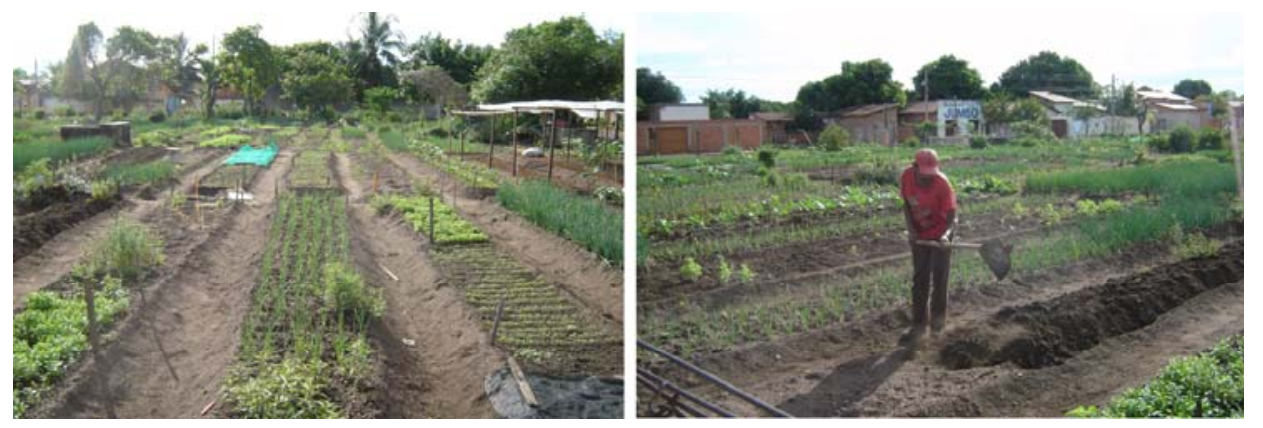

Fig. 71, Horta comunitánia da Amo 33 gerida pela comunida de loc al. (Fonte: a utor, 2007)

O Parque Sussuapara, outro espaço projetado para gerar qualidade urbana para a Vila União, é utilizado apenas em alguns momentos da semana e por poucos jovens, que vão praticar atividades como jogos de futebol e ciclismo. Uma grande parcela da população do bairro não utiliza o parque, que prefere se apropriar de espaços junto ao contexto urbano mais consolidado. O fato de estar em uma área de proteção ambiental e separando o bairro do centro da cidade, faz com que ele seja visto como uma barreira, e não como local de atração para uma vida pública coletiva.

O parque margeia o principal acesso a o centro, o cordão umbilical27 que liga as áreas da classe trabalhadora com a região onde há a maior concentração de empregos na capital. Este fato pode ser percebido pelo grande número de ciclistas e pedestres que transitam na via NS-01. Em

\footnotetext{
27 Termo adotado pelo autor para caracterizar uma via que liga a região que apresenta uma grande oferta de emprego e a região que apresenta uma grande oferta de mão de obra, criando uma dependência mútua.
} 
medição da prefeitura, em apenas uma hora do dia, no horánio das 7:00 às 8:00 horas da manhã, foram contabilizadas 500 bicicletas no sentido bairo centro. (Fonte: SEDUH, 2006)

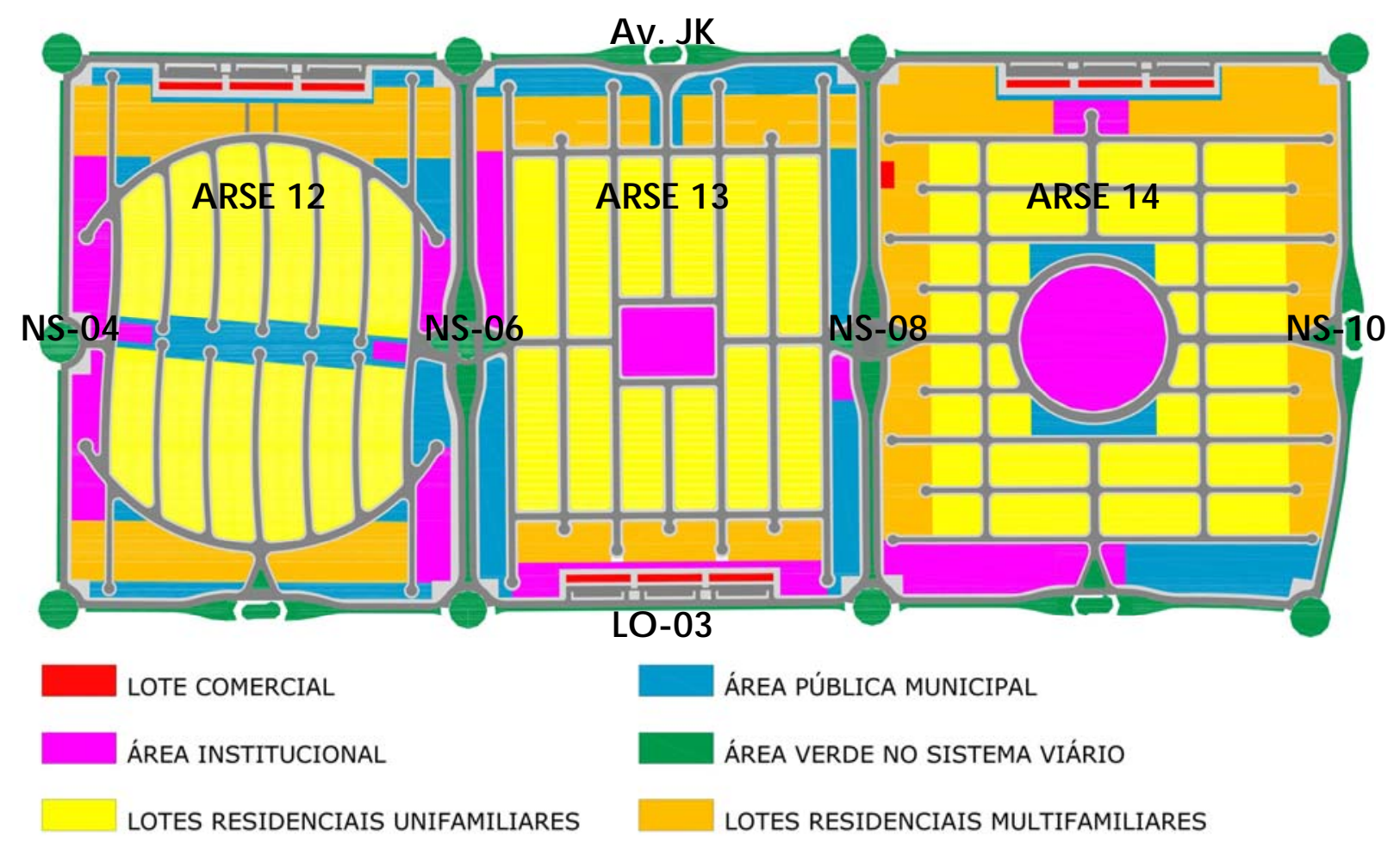

Fig. 72, Quadras Centrais seguindo premissas do plano. (Fonte: autor, 2006)

Se a Vila União é caracterizada pela ocupação informal, as quadras centrais tiveram um processo diferenciado de confomação. As quadras Arse 12, 13 e 14, representam fielmente a estrutura das unidades de vizinhança idealizada pelo plano. A Fig. 72 representa o projeto para as três quadras, seguindo o modelo de uso e ocupação. A principal diferença entre essas e a Vila União, é a presença de lotes multifamiliares nas bordas de cada quadra. Pretendia-se com isso diversificar a oferta de moradias e aumentar a densidade em cada unidade. Para isto utilizou-se como modelo um sistema viário fechado, com ruas intemas teminando em cul-de-sacs, privando-as de serem loca is de passagem entre quadras. Os quatro limites se altemam entre a cessos para o interior de cada unida de e comérc ios vic ina is, na corvermelha no desenho (Fig. 72). 
Dois fa tores são comuns aos projetos das quadras da região central: a utilização de uma grade ortogonal, mesmo na Arse12 que possui uma pequena sinuosidade no traçado, e a presença de uma praça central, com o intuito de criar uma centralidade e promover um espaço público de qualidade em cada unidade de vizinhança. Diferenciando-se pelo cadastro imobiliário da cidade, as áreas em lilás e azul, representam respectiva mente Áreas Instituciona is (AI) e Áreas Públicas Municipais (APM), porém algumas áreas institucionais tomaram-se praças, como na Arse 13 e 14.

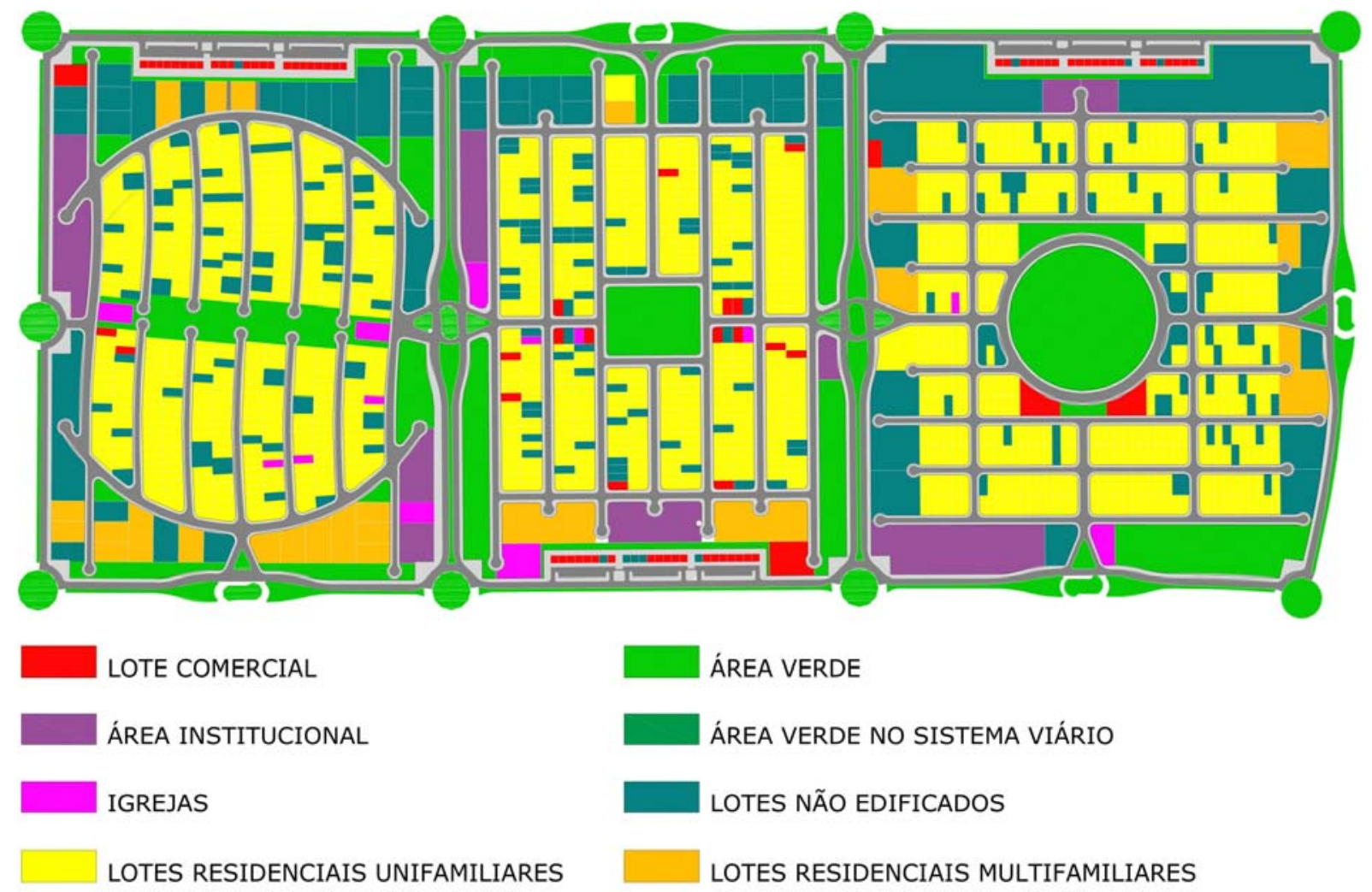

Fig. 73, Quadra Centra is na atualidade. (Fonte: autor, 2006)

A Fig. 73 representa a situação das três quadras centrais na atualidade. Pouca mudança em relação ao projetado ocorreu, porém, o que se percebe é ainda uma grande quantidade de terrenos ainda sem edificação. A principal especulação imobiliária em Palmas se concentra nessa região, fazendo com que o custo dos lotes seja ma is caro em relação a outrasjá lotea dase comercializa das. 
O atual esforço da prefeitura em conjunto com a população, em frear esse modelo de desenvolvimento, incide em alterar alguns pontos do plano. Embora não seja objeto desta análise, o novo Plano Diretor de Palmas cidade revela as deficiências do plano e do processo de construção da cidade, e os problemas originados pela gestão, inscritos no seu espaço. 0 ponto principal deste novo plano refere-se à tentativa de unir e promover uma maior interação entre as duas cidades existentes, a da área projetada, e a região que compreende Taquaralto e Aurenys, ao sul. Emprego, transporte, proteção de áreas verdes, infra-estrutura, são pontos que também mereceram destaque nesta discussão. Para a área central, a principal medida estipulada pela prefeitura é o adensamento dessas quadras.
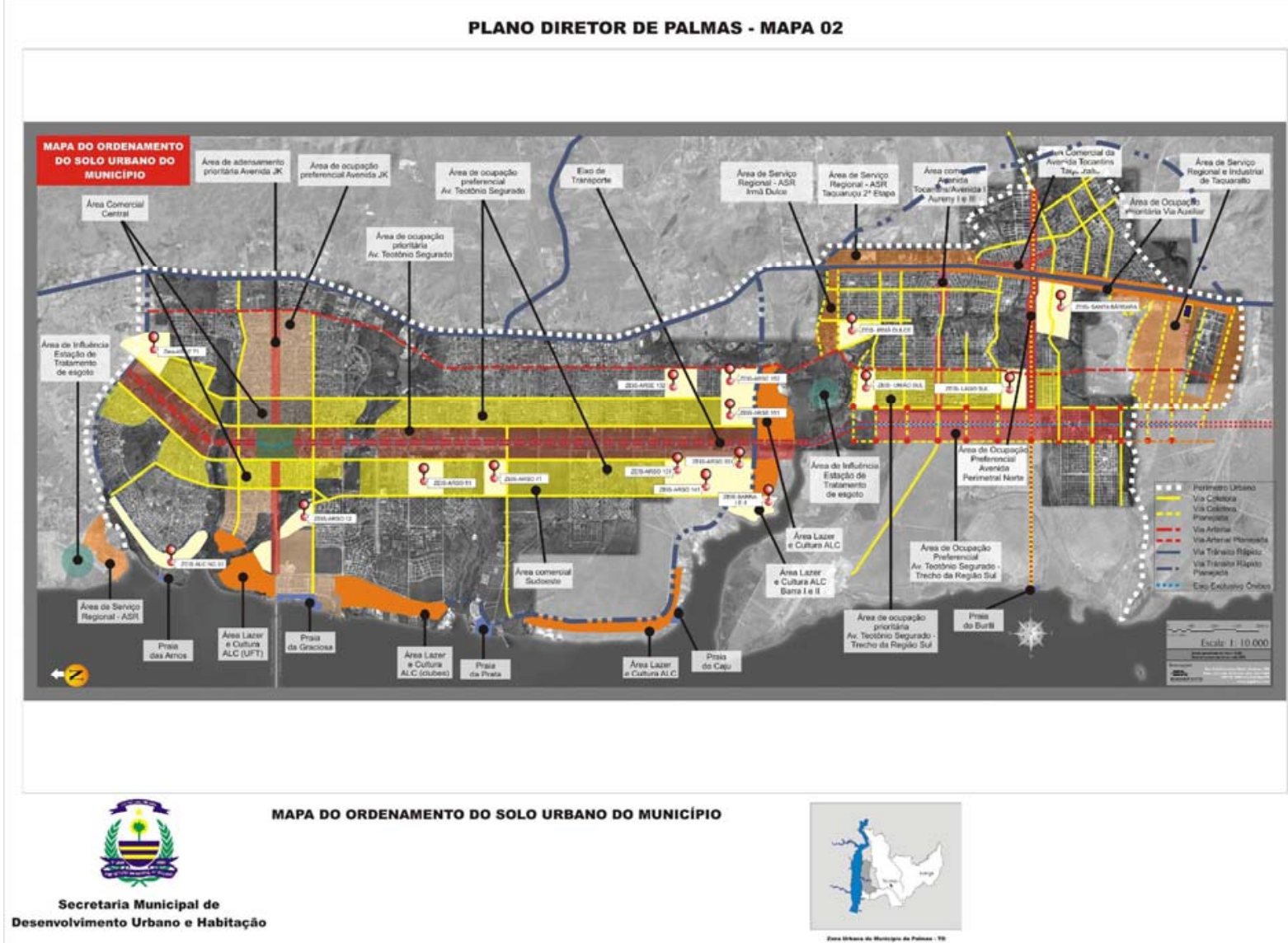

Fig. 74, Imagem síntese das propostas elaboradas no Plano Diretor de Palmas. (Fonte: SEDUH, 2007) 


\section{Múltipla centralidade}

Os planejadores da cidade de Palmas, seguindo em grande parte os tratados e pressupostos de uma cidade modemista, foram os responsáveis pelo desenho urbano que definiu e fragmentou a cidade em setores. A definição do plano por setores, definiu não só o traçado urbano, mas toda a dinâmica espacial e social da formação da cidade.

A setorização urbana se tomou uma ferramenta indispensável ao planejamento modemo e ordenamento das cidades. A separação por funções tem como princípio inscrever no espaço urbano um desempenho específico quanto ao uso, objetivando direcionar e ordenar a sua ocupação, criando condições adequadas para que cada setor tenha um bom desempenho individualmente e no conjunto de toda cidade. Esse modelo estabelecido como primordial para regulamentar e legitimar, é resultado do planejamento urbano como uma ciência capaz de ser aplicada por padrões técnicos de produção do espaço, categorizada pela modemidade pré-estabelecida pelos padrões que derivaram da cidade industrial e dos novos meios de circulação. A formulação de um plano tem como estímulo inicial resolver e condicionar todas as relações existentes no espaço através do seu ordenamento, incidindo em projetos com diferentes graus de determinismo e fragmentação.

\footnotetext{
"A arquitetura da cidade reduziu-se a seu aspecto funcional, colocando porterra a antiga aliança entre forma e desenvolvimento das práticas sociais que estabelecia a localização de atividades configurando, juntamente com seus dema is elementos construtivos, a imagem das cidades, impregnada de caráter e singularidade, compondo a história das sociedades urbanas." (KOHLSDORF, 1996, p 24)
}

Um dos pontos levantados por Pesci (1999) corresponde ao princípio da Multifocalidade, premissa projetual que contribui para uma cidade melhor, pois provoca múltiplas centralidades: Consiste em auspiciar as protocentralidades de atividades e espaços que se encontram nos bairros, na periferia, fazendo destes focos de decisão e concentração de atividades. 


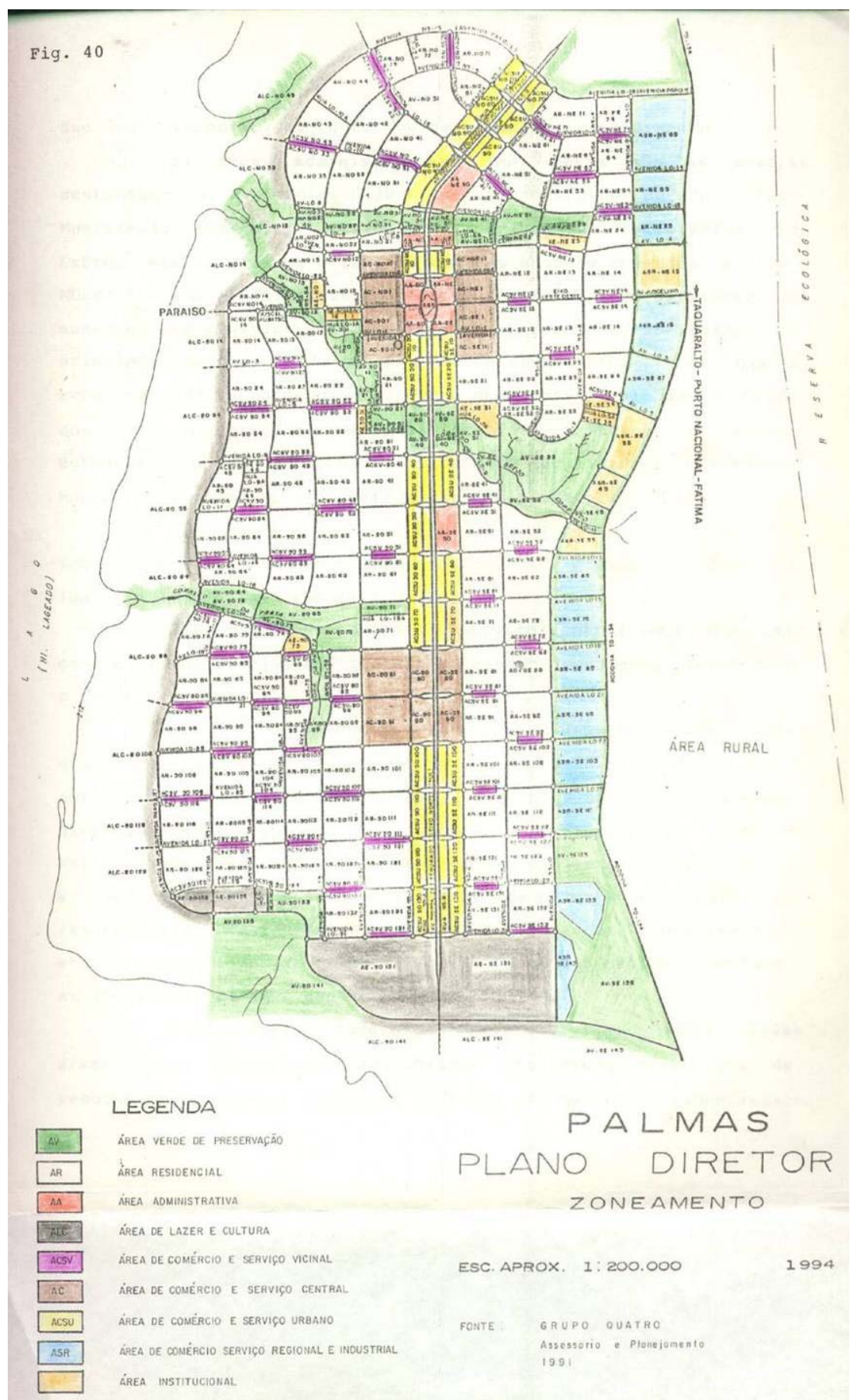

Fig. 75, Plano diretor da cida de com as “áreas” pré-estabelecidas. (Fonte: URA, 1995)

O plano de Palmas apresenta diferentes graus de determinismo. Ao mesmo tempo em que a cidade apresenta uma rigidez nas definições específicas, ela permite uma flexibilidade quanto ao desenho das quadras, impondo apenas padrões de uso e taxas de ocupação como condicionantes. Isso permitiu não somente uma diversidade das tramas urbanas, mas ta mbém pequenas rupturas entre o planeja do e o constituído, 
mesclando marcas do traçado projetado com processos culturais de apropriação. A centralização decorrente da funcionalidade e da fragmentação do plano, gerou problemas quanto às dinâmicas socia is nos espaços públicos, incidindo diretamente na qualidade urbana proposta pelo plano original.

"A razão técnica acredita que sabe organizar do melhor modo possível pessoas e coisas, a cada um atribuindo um lugar, um papel e produtos a consumir. Mas o homem ordinário escapa silenciosamente a essa confomação. Ele inventa o cotidiano, graças às artes de fazer, astúcias sutis, tátic as de resistência pelas qua is ele altera os objetos e os códigos, se reapropria do espaço e do uso a seu jeito." (C ERTEAU, 1996)

A principal centralidade da área planejada, região fomada pelos arredores da Praça dos Girassóis, engloba não só a área comercial, mas também os setores administrativos e instituciona is da parte monumental da cidade. Novos pólos surgiram nos distritos que se formaram com 0 crescimento desordenado da cidade, como a região de Taquaralto e Aurenys, importante pela sua dinâmica social e econômica, consolidada através do tempo como uma pequena cidade junto ao plano.

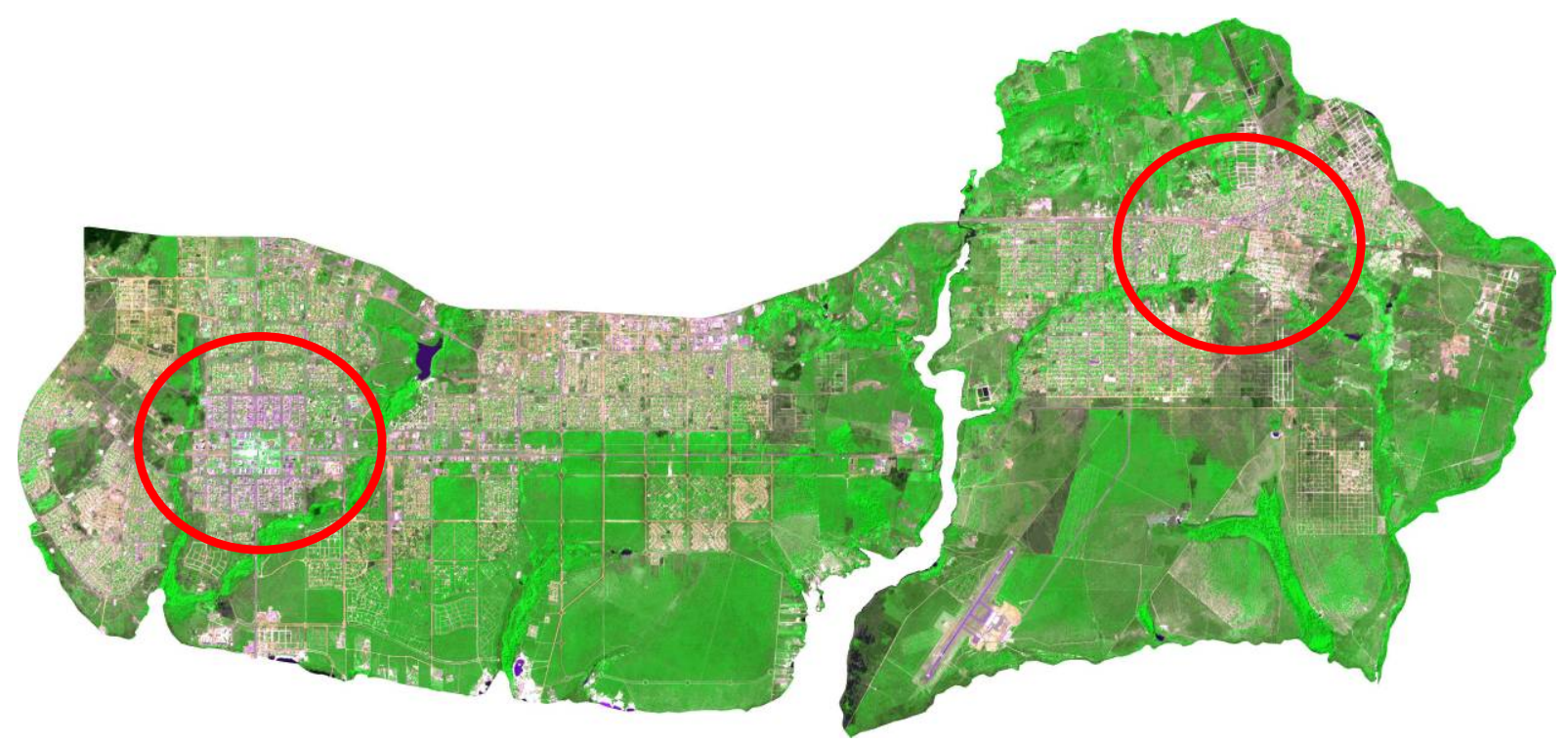

Fig. 76, Duas principa is centra lidades: Palmas Centro e Taqua ralto. (Fonte: autor, 2006) 
O centro da cidade é atualmente foco de discussão do poder público para promover a sua revitalização. A divisão funcional condicionou uma situação comum a muitas cidades brasileiras - uso intenso durante o peńodo comercial, e seu esvaziamento e subutilização nos demais períodos ocasionando a já preocupação dos urbanistas em revitalizar e incentivar novas formas de ocupação para essasáreas. A concentração das funções é parte da estratégia do desenho e da boa forma da cidade, porém incide diretamente na sua urbanidade.

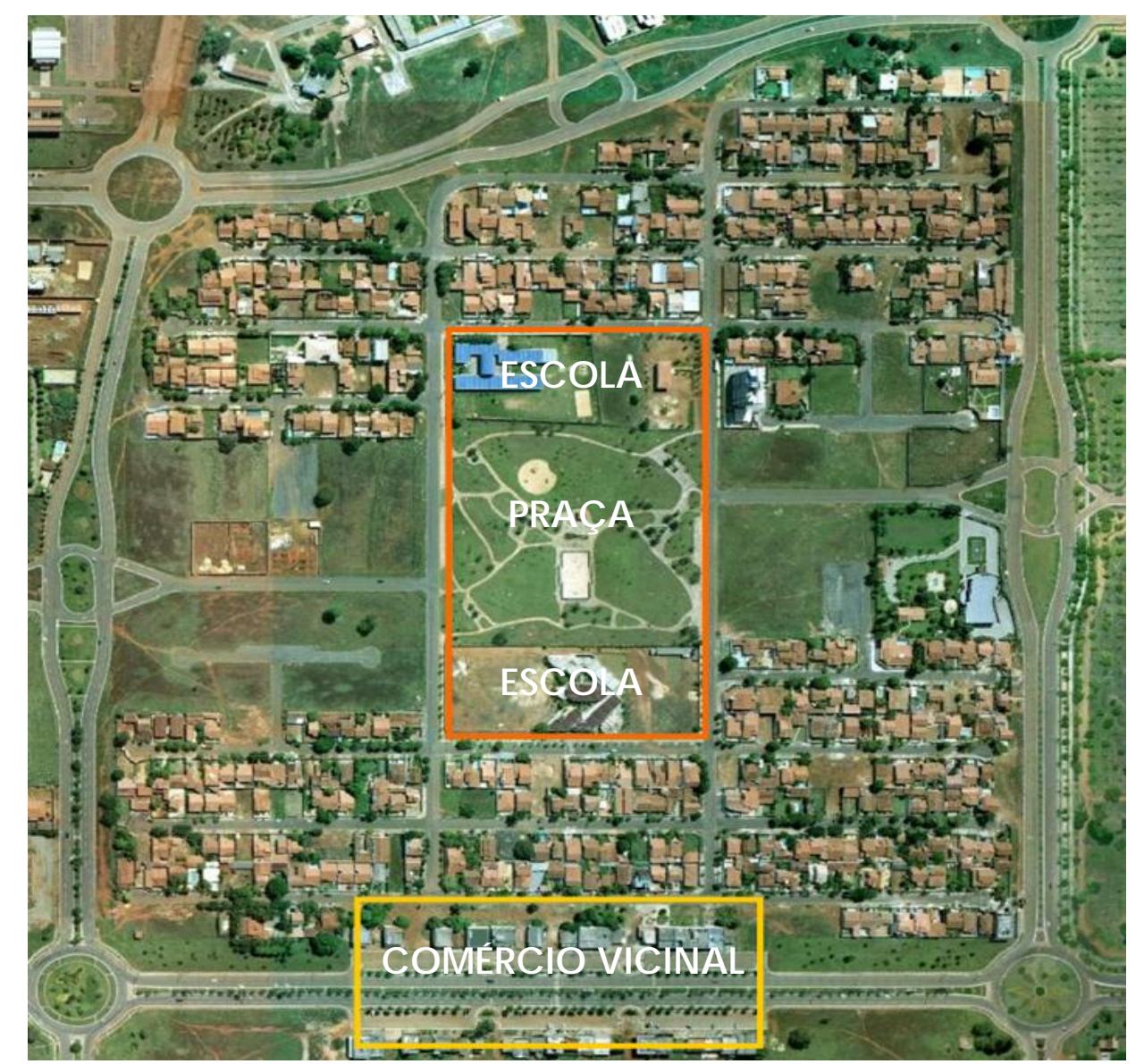

Fig. 77, Centralidades de uma quadra central: comércio, praça e escola. (Fonte: SEDUH, 2005)

As unida des de vizinhança, delimita das e estipuladas pelo projeto para promover uma diversidade e intensidade de apropriação do espaço, apresentam pontos de atratividade definidos para proporcionar a sua vitalidade urbana. A primeira se destaca pelo seu uso comercial. O comércio vicinal localiza do em todas as avenidas Leste-Oeste da cidade 
(LO), deve atender tanto o morador da quadra, como os que circulam pelas avenidas, estabelecendo em cada uma, um centro com pequenos comércios, escritórios, serviços, e outros equipamentos que as servem principalmente. Devemos refutar qualquer modelo que encare os bairros como unida des a uto-sufic ientes ou introvertidas. (J ACOBS, 2000, p 125)

A segunda é conformada no centro de cada quadra. Nestas, o projeto previa praças e escolas, e pequenos estabelecimentos comerciais, criando uma importante zona de convergência, e remetendo ao conceito original de unidade de vizinhança de Perry. Porém muitas não incorporaram estes elementos no desenho, alterando o conceito original, mas em alguns casos, ainda formadores de centralidades.

A concentração de um único local com um uso específico restringe a diversidade que o ambiente urbano pode proporcionar, incidindo assim na sua dinâmica. Em contrapartida, a múltipla centralidade pode formar uma rede, que atra vés de estruturas visíveis ou invisíveis, se intenligam no espaço. Algumas muta ções determinadas pelo descumprimento ou transgressão a os condicionantes do projeto, resultaram em novos focos de convergência e uso da população. Esse é um processo urbano que visa distribuir as diferentes formas de apropriação do espaço, criando novos lugares no tecido urbano, com novos signific adose identidades.

A diversidade abastece a esfera pública da vida cotidiana nos lugares, condicionando a sua apropriação e a sua vitalidade. Os pontos determinados pelo projeto para serem pólos nas unidades de vizinhança são ma is visíveis nas quadras centrais, porém algumas modific a ções ocorreram em diferentes níveis, implementando de forma positiva a urbanidade nestas.

“Planejar a cidade é ao mesmo tempo pensar a própria pluralidade do real e dar efetividade a este pensamento do plural: é saber e poder artic ular." (CERTEAU, 1996, p 172)

Nas quadras estudadas, a pluralidade colocada por Certea u ocorre em diferentes graus. O projeto original das unidades de vizinhança da Vila União seguiu as mesmas premissas projetuais: comércio vicinal com 
altemância entre quadras, com exceção da Amo 32 que se localizam em dois pontos; e praças, escolas e igrejas em seu interior. Essa orientação respeitou as diretrizes de ordenamento, onde cada lote e área têm sua função urbana pré-estabelecida, proporcionando à cidade uma nomatização tanto na linguagem que se repete quanto na legibilidade que se cria padronizando os locais de acordo com cada função.

Esse modelo representa uma parcela igualitária do conjunto urbano em grelha que se repete. Se a função destes é a de reforçar a unidade como elemento propulsor de qualidade de vida urbana e social, a forma nucleada faz com que haja uma diminuição da força destes espaços como focos geradores de intera ções socia is.

Muitas unidades de vizinhança que se conformaram, contrapuseram algumas determinações estabelecidas pelo plano, ora por negligência do poder público, ora por própria conivência para a facilitação do processo de apropriação fundiária e desenvolvimento da cidade. As rupturas no plano geral e na escala das quadras, proporcionou um híbrido de desordenamento e ordenamento, ocasionando novos signific a dos espacia is derivados desta situa ção.

Nas quadras centrais, pequenas e sutis transgressões alteraram a sua dinâmica, porém a marca do deteminado ainda prevalece na sua organização. Na Vila União, as transgressões foram mais marcantes, e redefiniram a dinâmica espacial da região. As figuras 78 a 87 apresentam as os pontos de convergência e os movimentos no espaço inicialmente previstos seguindo o padrão projetual, e os novos pontos que se conformaram diante de processos sociais diferenciados.

Os marcos em amarelo e as setas na cor preta caracterizam os pontos de convergência estabelecidos como ideais para o funcionamento das unidades de vizinhança, e os movimentos no espaço que caracterizam uma hierarquia urbana definida pelo projeto. Os marcos e as setas em vermelho, as novas centralidades e movimentos. A altemância no sentido das direções em cada quadra fortalece a determinação do plano em distribuir os focos de maior atração pelo espaço da cidade, criando marcosurbanos. 


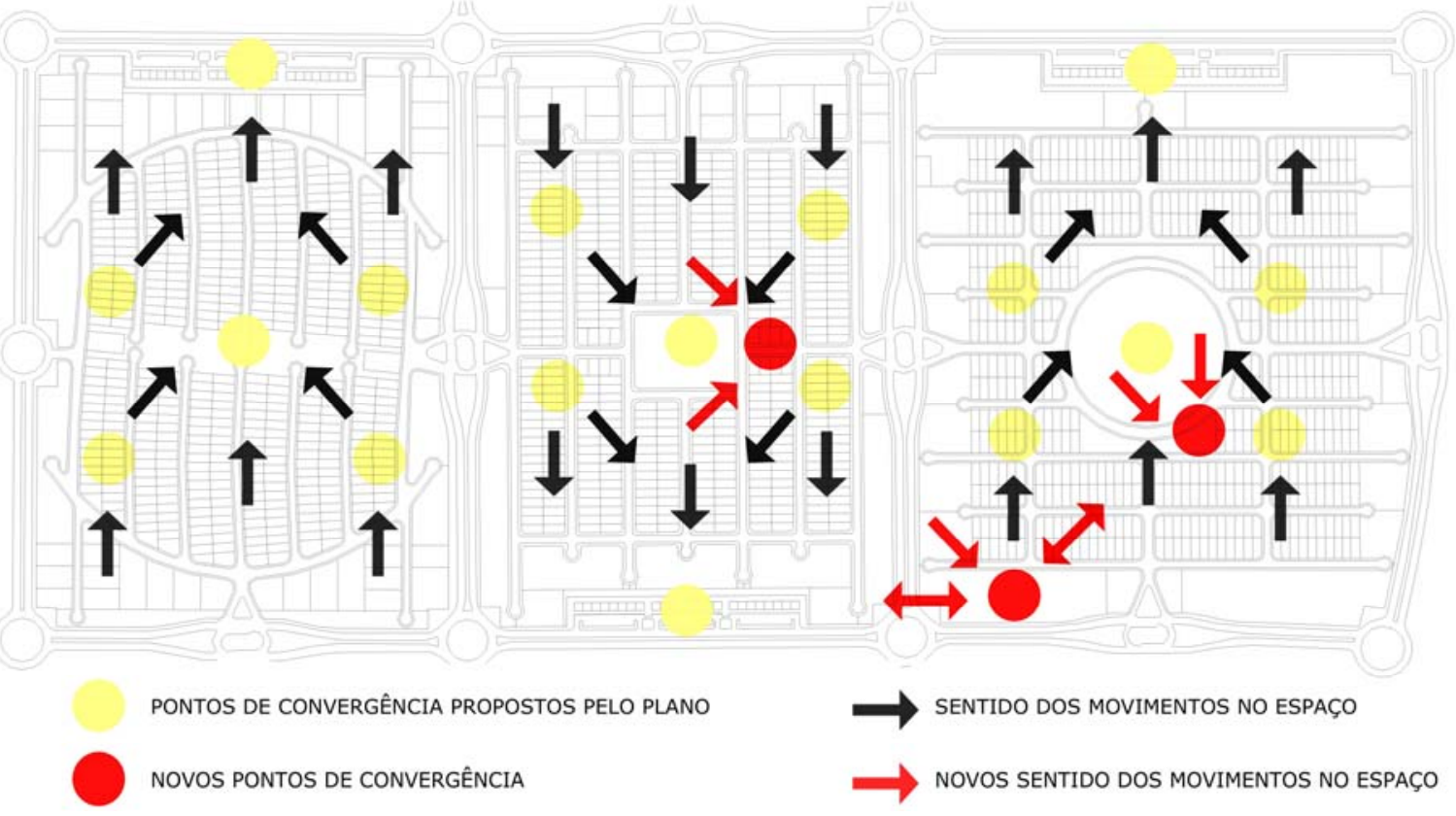

Fig. 78, Centralida des consolida das na região central. (Fonte: a utor, 2006)

Tanto os pontos delimitados pelo plano como pelos processos de urbanização, se destacam no contexto urbano como espaços do convívio coletivo e principalmente da esfera pública nas quadras. Mesmo com a uniformização das diretrizes espaciais, cada quadra apresenta característic as que conferem a ela identidadese signific ados.
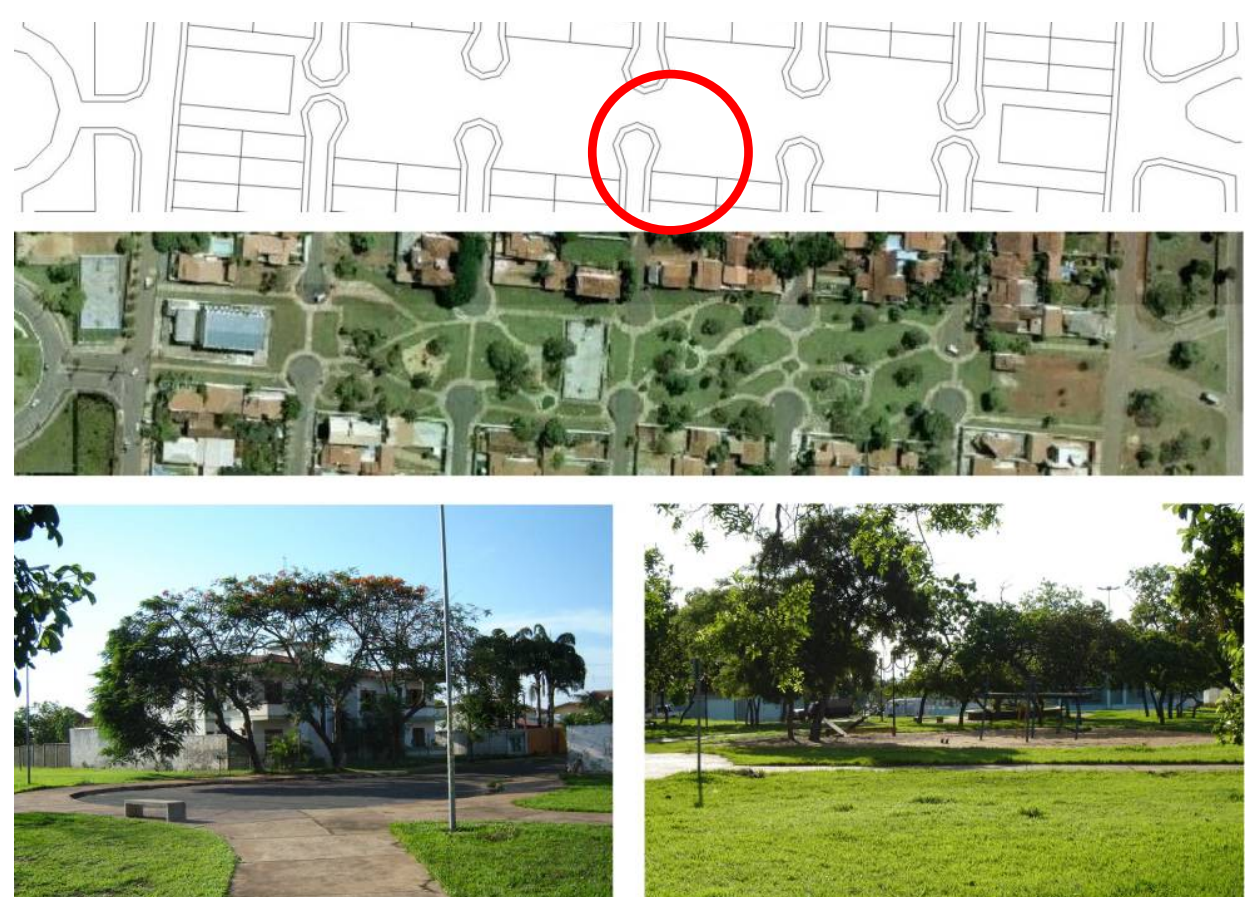

Fig. 79, Praça central da Arse 12: Praça encravada em meio à cul-de-sacs, aumentando os pontoscegos no meio da quadra. (Fonte: autor, 2006) 
A Arse 12 é a quadra mais próxima da região central, influenciada pela força de seu comércio vicinal que se configura como uma extensão do comércio da Avenida JK, o principal da cidade (Fig. 79). Um espaço fundamental é sua praça, um importante espaço que se configurou, principalmente pela sua localização, e que serve como corredor de passagem para o centro comercial da cidade e de local de lazer para seus moradores.
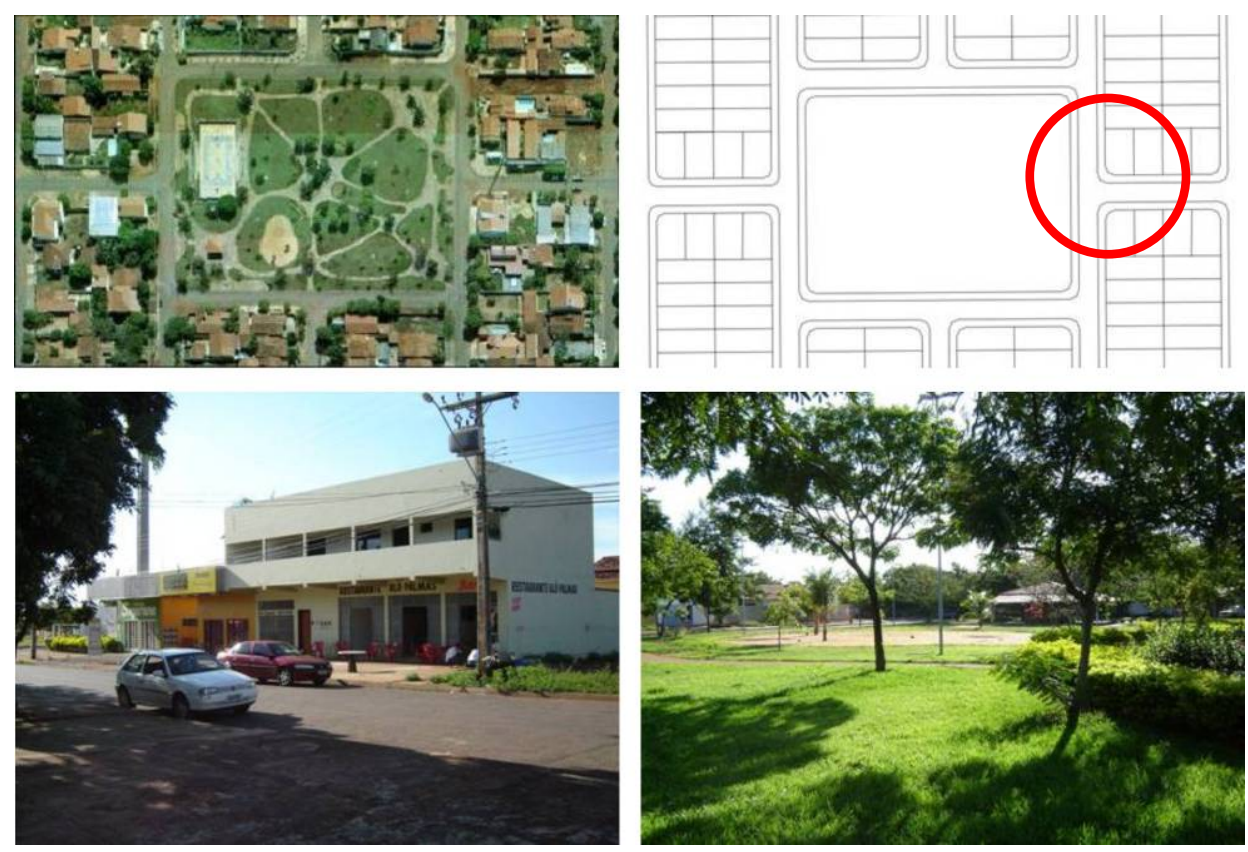

Fig. 80, Centralidades da Arse 13: a praça central e o comércio concentrado nos arredores. (Fonte: a utor, 2006)

$\mathrm{Na}$ Arse13, os focos de convergência praticamente não sofreram alteração, concentrando-se no comércio vicinal e no entomo de sua praça. Pequenos estabelecimentos estão fomando um novo local para necessidades diárias e com isso descentra lizando o setor comercial vicinal. Embora ainda timidamente, já representa um indicador de que a distribuição destes equipamentos aumenta a sua intensida de de uso.

Primeira quadra ocupada no setor, a Arse 14, tem sua praça intema como articuladora dos fluxos e de um intenso uso público. Sua constituição remete à história da cidade, quando esta era o principal ponto de convergência da população da região central, que não contava com 
nenhuma área de lazer público nas proximidades, já que as demais praças das quadras e a atual configuração da Praça dos Girassóis ainda não tinham sido construídas.
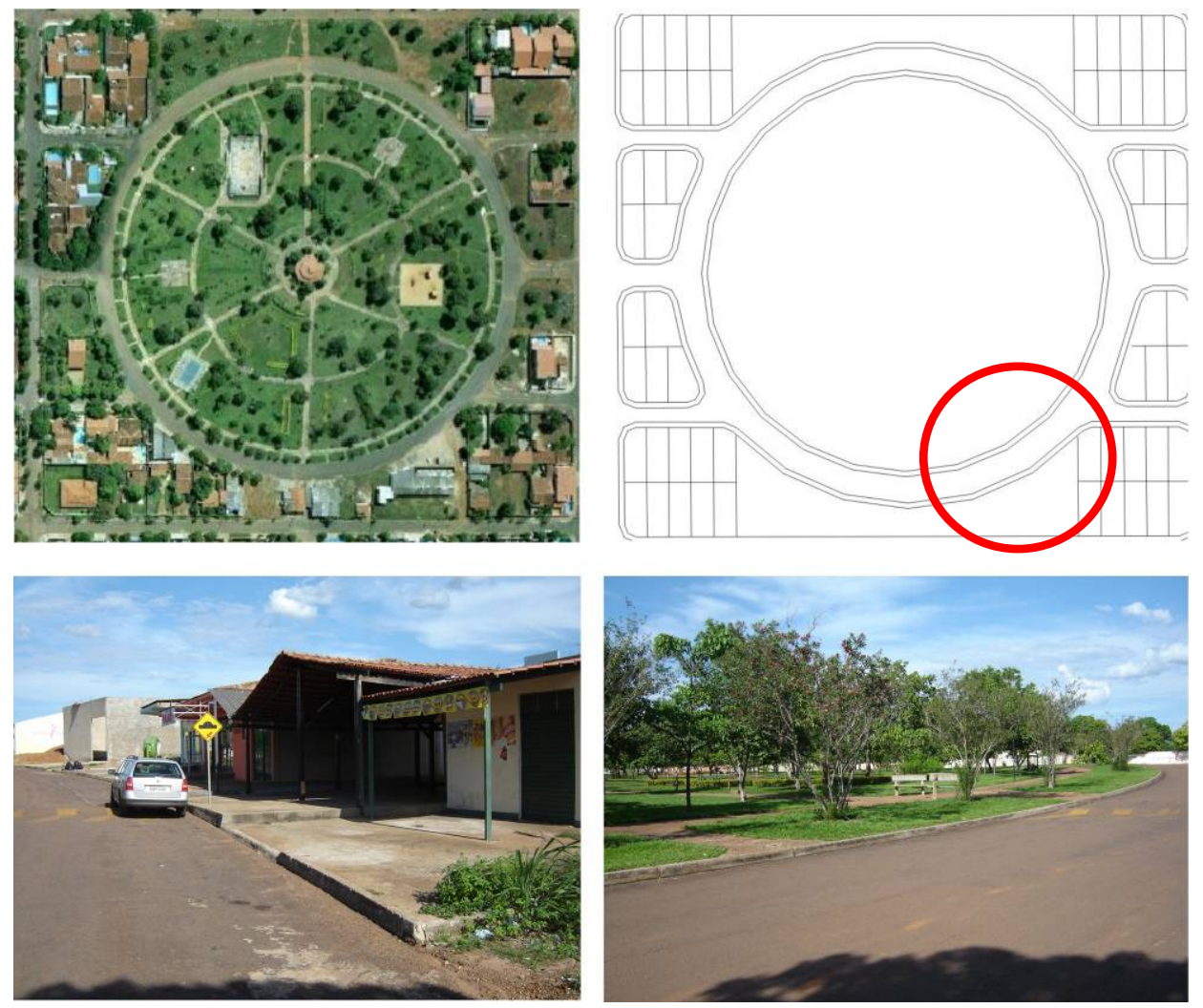

Fig. 81, Centralidade da Arse 14 - comércio junto a Praça. (Fonte: autor, 2006)

À medida que outras praças foram sendo equipadas e concluídas, esta perdeu importância junto aos moradores da região, porém ainda é um ponto de convergência de muitos habitantes. Esta a trai pela diversidade de equipamentos em seu interior, e pelos pequenos estabelecimentos comerciais se instalaram no seu entomo, em áreas públicas. Essa transgressão a legislação a carretou em um importante pólo de atração.

Outra importante alteração foi a construção de uma escola particular em um lote destina do a escolas municipais, o Colégio Marista, o maior de Palmas. A relevância deste para a cidade fez com que proporcionasse um importante ponto de atratividade, gerando articulação entre a Arse 14 e as outras quadras. 
Os comércios vicinais, que na região central são importantes pontos de atração da população, na Vila União, não se configuraram como centralidades, permanecendo às margens do desenvolvimento urbano da área. Novos pontos comercia is se configuraram, permitindo a distribuição dos fluxos pelas quadras. A conformação poli-nucleada abastece o espaço urbano de uma interatividade benéfica para o seu projeto.

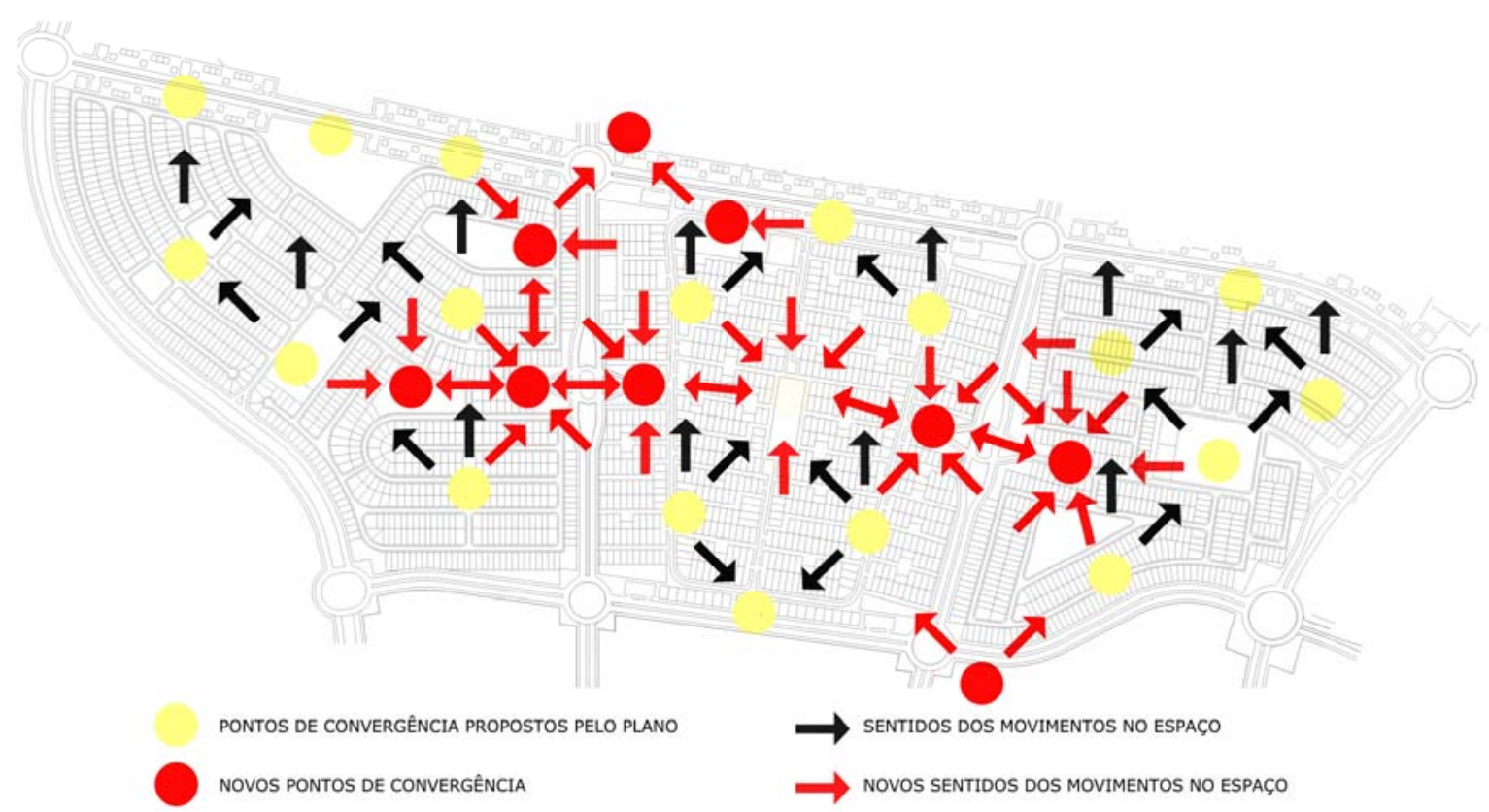

Fig. 82, Centralida des consolidadas na Vila União. (Fonte: autor, 2006)

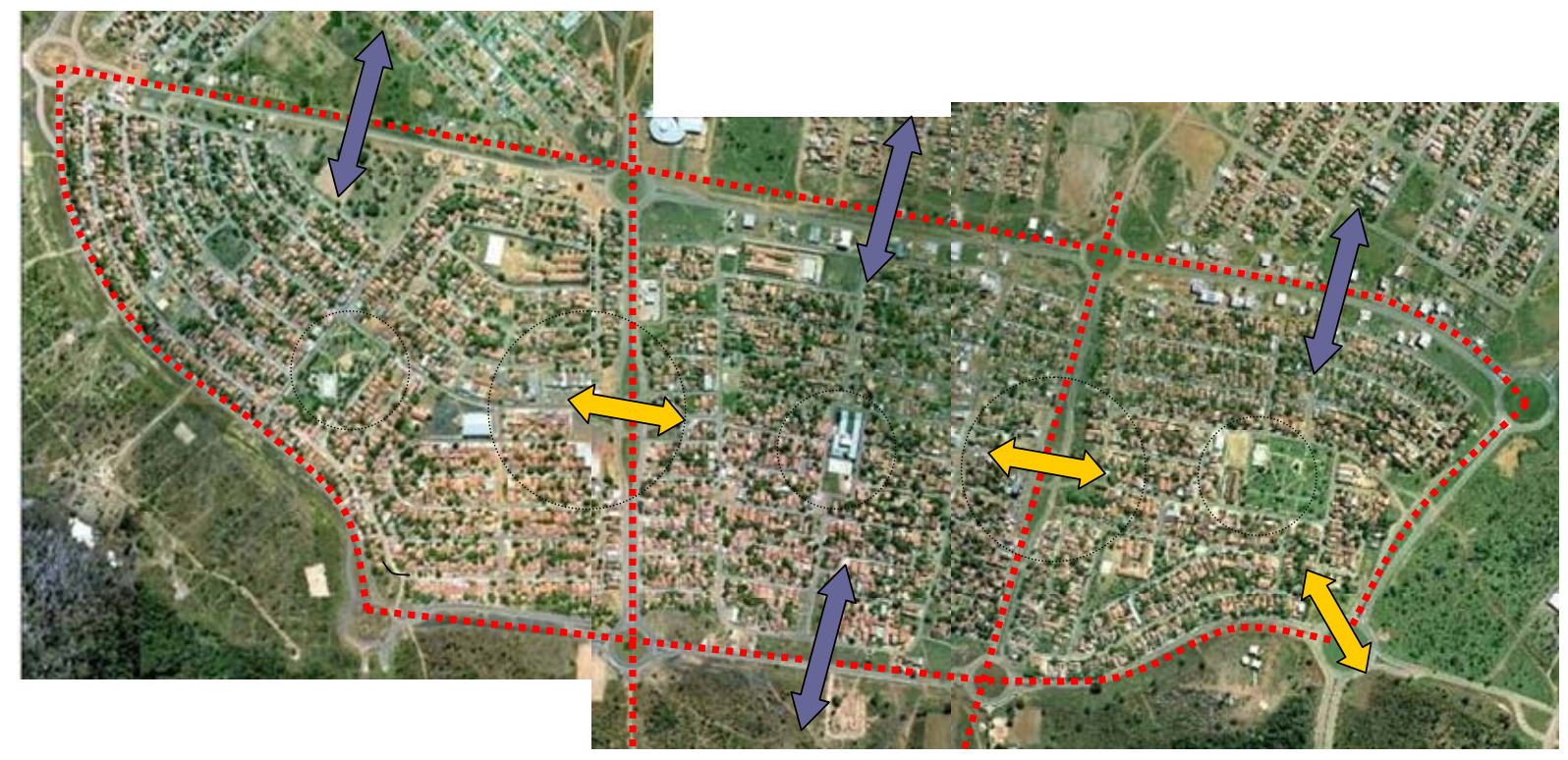

Fig. 83, Centra lida des da Vila União: as seta s em lilá sindicam as continuida des espac ia is prevista s pelo projeto; os círculos em azul são as novas centra lida des e as setas em a ma relo as continuidades espacia is que se conformaram. (Fonte: autor, 2006) 
Uma rede de novos pontos se configurou no espaço urbano, conectando e influenciando a vida urbana e o cotidiano de seus moradores. Esses resultaram em um sistema de espaços integrados pelos movimentos humanos, a umentando a conectividade e conferindo a ele um caráter de bairro unificado, e que distribui homogeneamente o uso e apropriação do espaço público. A Fig. 82 as representa, tanto as previstas, como as constituídas pelo processo de ocupação.
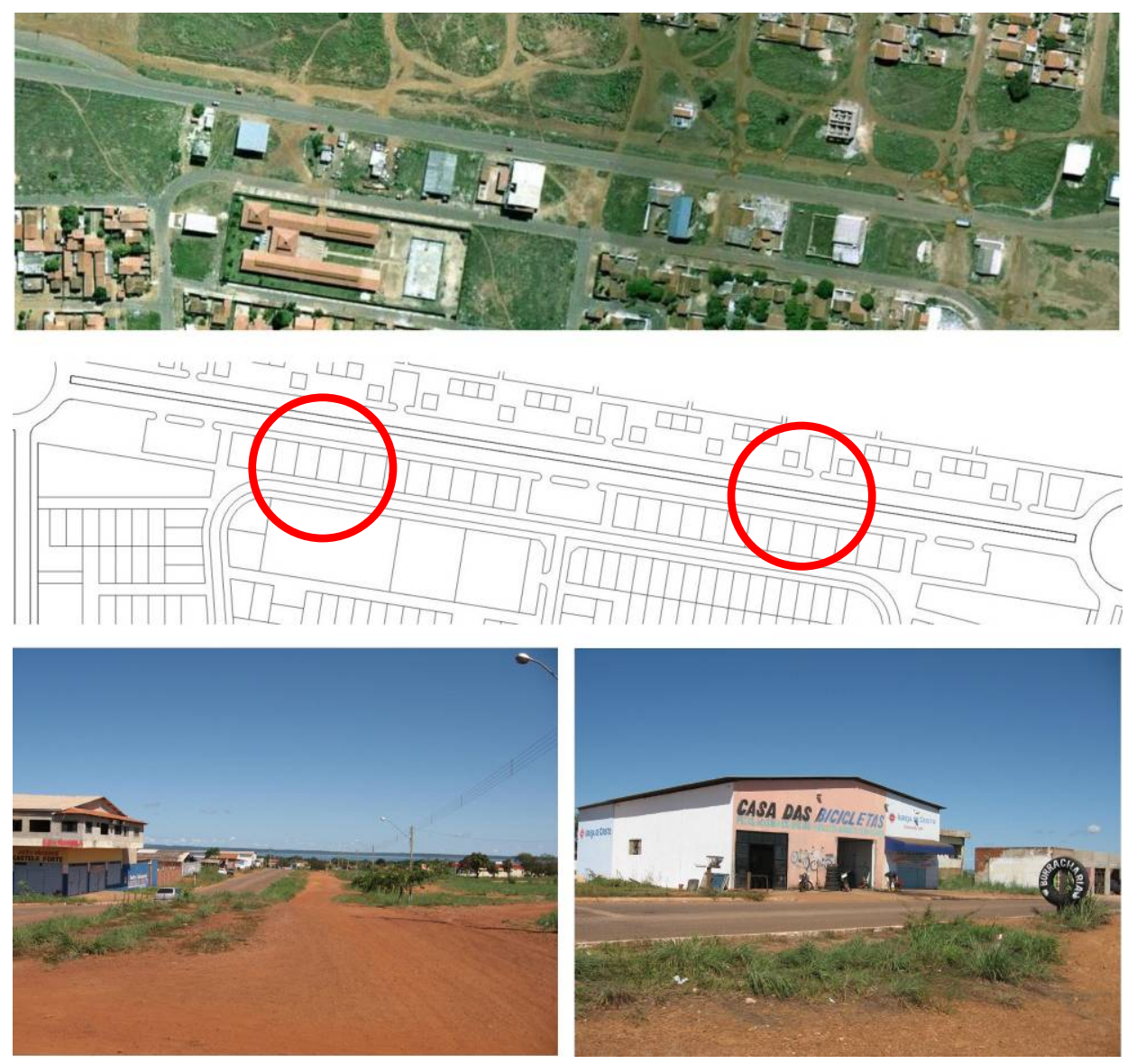

Fig. 84, Comérc io vic inal da Amo 32: centralidade do projeto que não se consolidou no processo de construção espacial. (autor, 2006)

Na Amo 31, os estabelecimentos comerciais se fomaram no entomo da praça central e na alameda de entrada da quadra. O grande fluxo gerado pela localização e estratégica posição perante as demais, transfomou os lotes residenciais em comerciais, alterando a dinâmica concebida pelo projeto. Na Fig. 85 percebe-se a conformação da paisagem local, contribuindo para uma nova esfera urbana e social. 

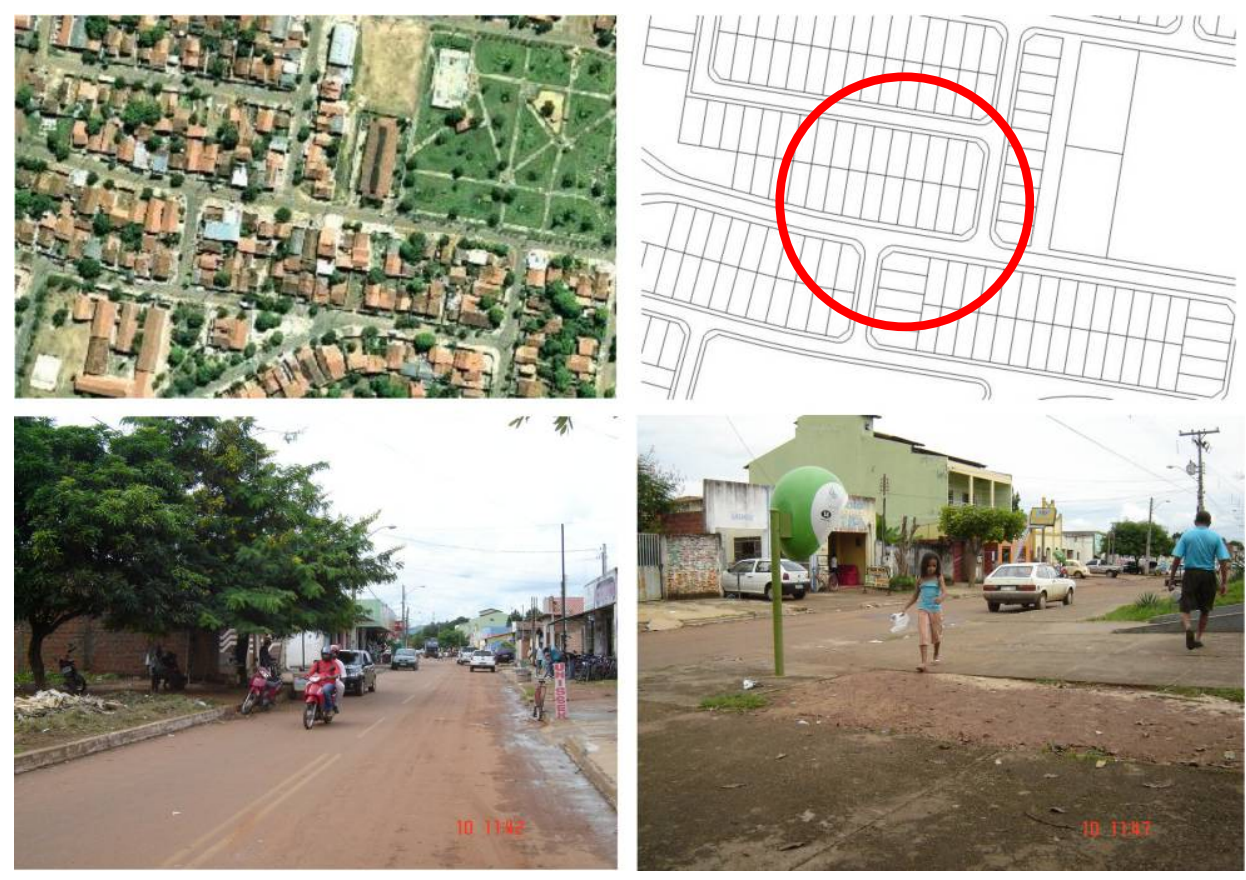

Fig. 85, Centralidade conformada no interior da Amo 31. (Fonte: a utor, 2006)
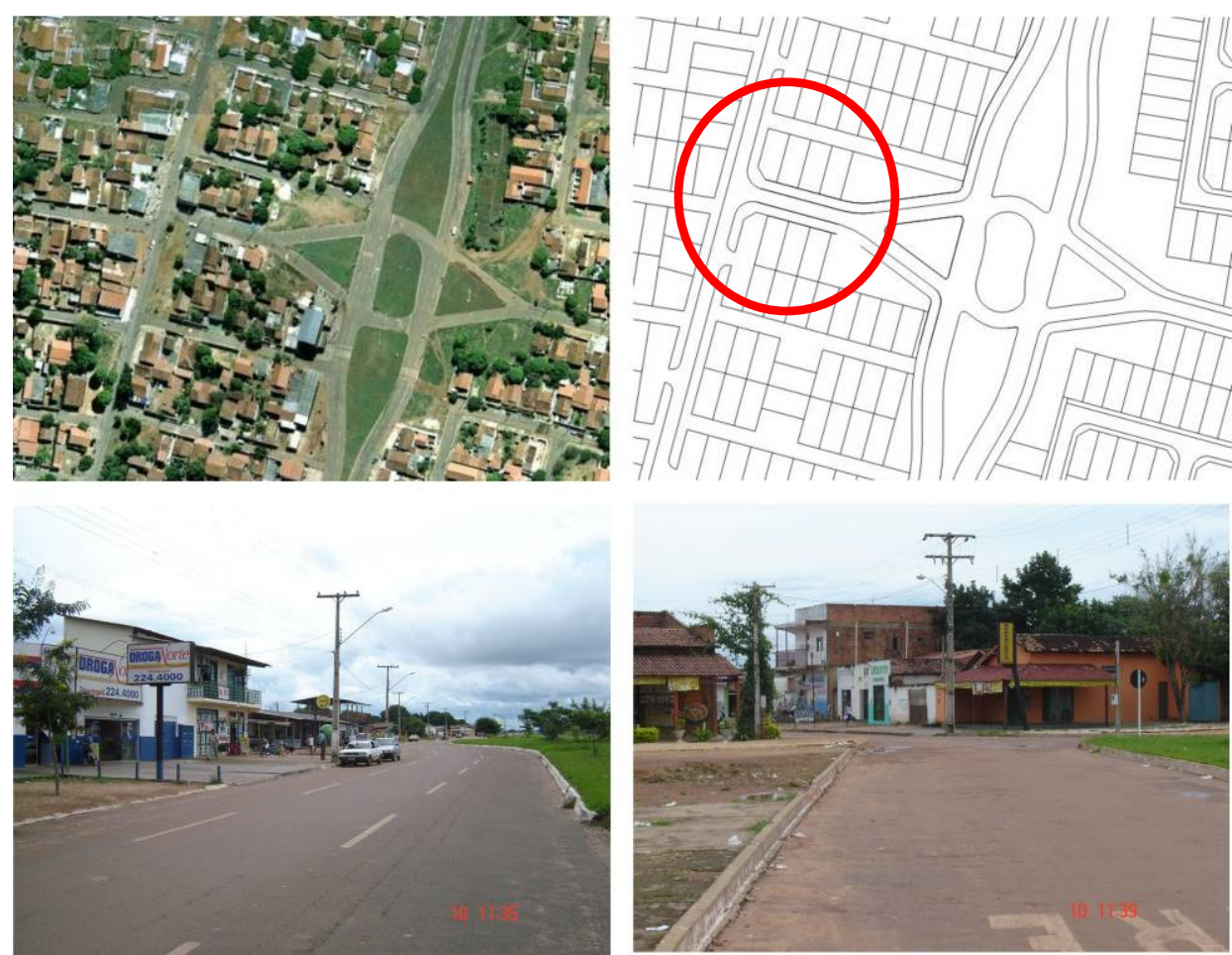

Fig. 86, Centralida de no acesso viário entre a Amo 31 e 32. (Fonte: autor, 2006)

A Fig. 86 retrata uma continuação da Amo 31. O trevo viário da avenida NS-03, que a separa da Amo 32, se conformou como um importante lugar de lazer e serviços para seus moradores. Na região central, as entradas são resenvadas para lotes residenciais, assim como no projeto original das 
quadras da Vila União, porém, com a mudança de uso, ocorreu uma nova configuração dos pontos de convergência para população local.
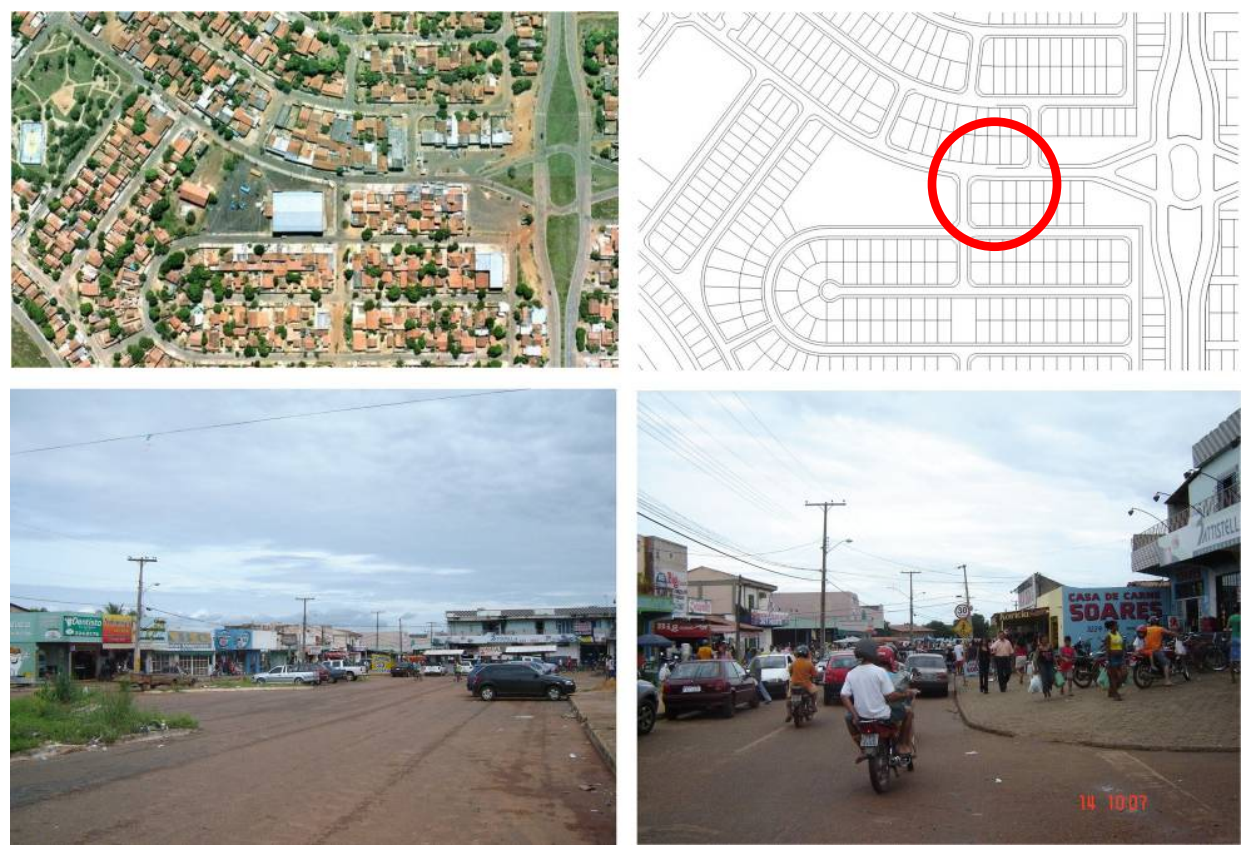

Fig. 87, Centralidade na entrada da quadra Amo 33. (Fonte: autor, 2006)

No eixo viário entre a Amo 32 e 33 o processo foi semelhante, porém com maior intensidade. O comércio que se formou no acesso da quadra 33 e na Alameda 09, se tomou o ponto nevrálgico da Vila União, e principal atrativo e referência espacial da região. Essa transformação revelou todo o processo cultural de conformação do espaço pelas forças das práticas socia is, contra pondo os limites impostos pelo desenho, que por vezes subjuga tais processos, e que são determinantes para a consolidação da esfera pública, em detrimento da sua conforma ção estética e funcional.

\section{Conectividade}

A múltipla centralidade propicia urbanidade quando as tramas espa cia is apresentam maior axialidade e conectividade, contribuindo para a forma ção de um sistema de espaçoscom permeabilidade, e de uma rede de estruturas de movimentos no espaço urbano mais homogênea, 
aumentando a sua capilaridade. Os limites do projeto urbano se evidenciam nas formas como estas conexões podem ser estabelecidas, seja pelo traçado, ou por sua contraposição, nas rupturas ao modelo imposto pelo desenho. Em Pa Ima s essas a parecem seguind o esses dois modelos.

O projeto de Palmas foi estabelecido por conexões, distribuídas em uma grade ortogonal derivadas dos dois principa is eixos viários: a Avenida Teotônio e a Avenida JK, e pela condição topográfica do sítio natural, que possibilitaria a distribuição quase homogênea dos fluxos pela sua malha viária. A Fig. 88 demonstra a homogeneidade viária prevista pelo plano e como ele se comporta na atualidade.
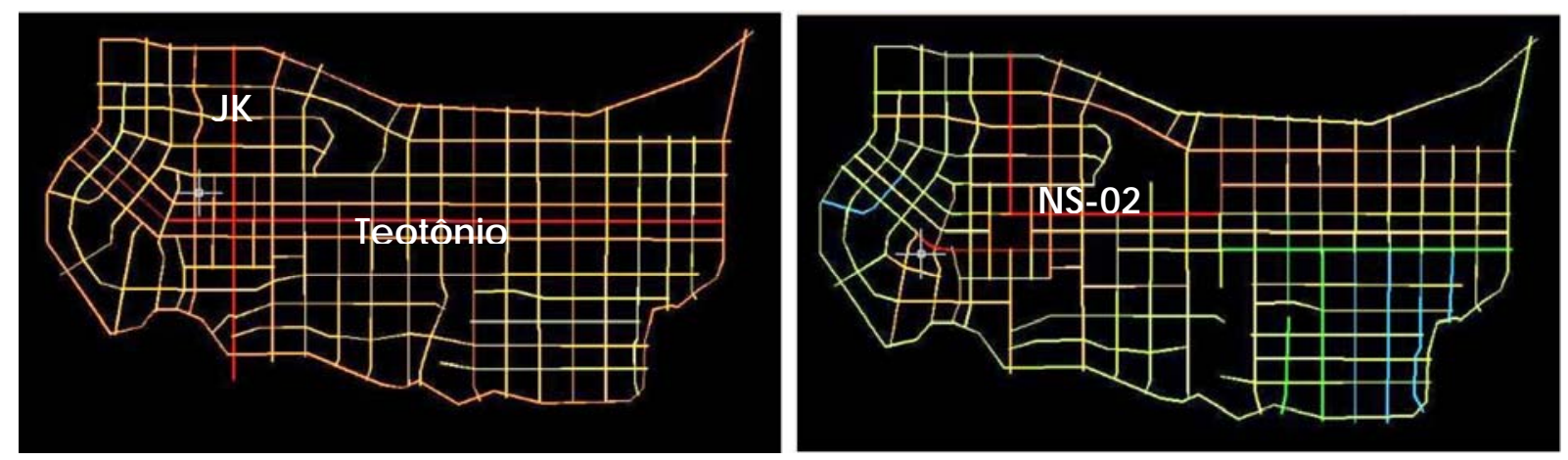

Fig. 88, Esquema axial da cidade de Palmas pelo plano e como a cidade se comporta na a tua lida de. (Fonte: a utor, 2007)

Um ponto a ser destacado é a perda da importância viária da Avenida Teotônio Segurado, que transferiu grande parte de seu fluxo para a Avenida NS-02, tomando-a a principal conexão entre o norte, o centro e o sul da cidade. A intemupção da Av. Teotônio pelo atual desenho da Praça dos Girassó is impossibilitou uma conexão direta entre os setores norte e sul da avenida, alterando assim o seu papel de articulador do sistema viário da cidade. Outra variável preponderante é o fato da cidade apresentar maior ocupação no quadrante sudeste da cidade, gerando um maiorfluxo para a Avenida NS-02. Mesmo considerando que a cidade ainda está em formação, a sua atual configuração influenciou na forma de se conectare se integrar. Essas transformações ocorrem com os mesmos condicionantes na sescala das unidades de vizinhanças. 
A funcionalidade cria conexões através de uma hierarquia urbana e viá ria pré-estabelecida, porém, as forças sociais que produzem os espaços acabam modificando esse perfil, condicionando-a as necessidades do cotidiano. Esta não é somente uma inscrição física no espaço, mas sensorial28. Locais produzidos para essa função podem impedir que outras formas de urbanidade ocorram. Em Palmas foi determina do um conjunto de praças centrais, liga das por passeios arborizadas e ladeadas por galerias. A conexão física não promoveu esse uso, transfomando os locais em nãolugares, fragmentá rios e não identitá rios.

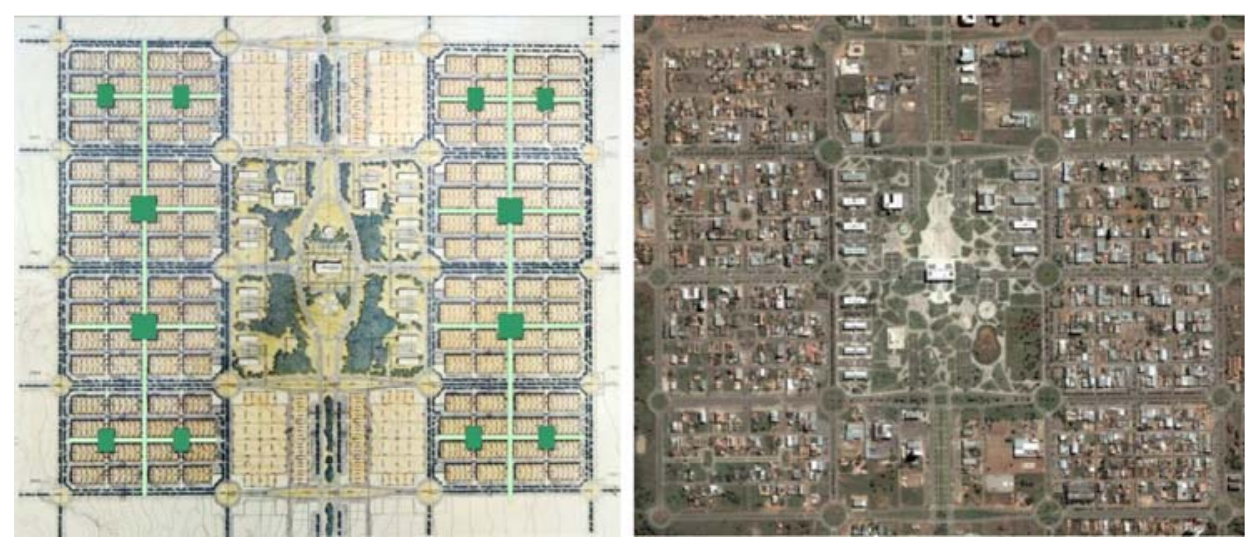

Fig. 89, Conjunto de praças planejadas para a região central. (Fonte: SEMUC, 2006)

O plano expôs suas fragilidades e possibilitou a criação de novas formas de conexão. Essas denotam uma outra condição para os espaços públicos, a de integração espacial. Estas, projetadas ou conformadas pelas práticas sociais, têm diferentes graus de atratividade. Os focos de atração da população nas unidades de vizinhança geram no espaço uma estrutura que se condiciona à trama urbana imposta pelo projeto, porém muitas delas, só são possíveis a tra vés da ruptura com o traçado, inscrevendo novos caminhose percursos que deteminam os modos de a propriação pública na cidade.

28 O sensorial remete ao processo cognitivo destacado no livro Apreensão da Forma da Cidade de Kohlsdorf, que permite uma leitura individual do espaço urbano, caracterizando potencialidades específicas a a preensão e entendimento da tota lidade e do fragmento pelo indivíduo: tra nsformação de sina is em signos. 


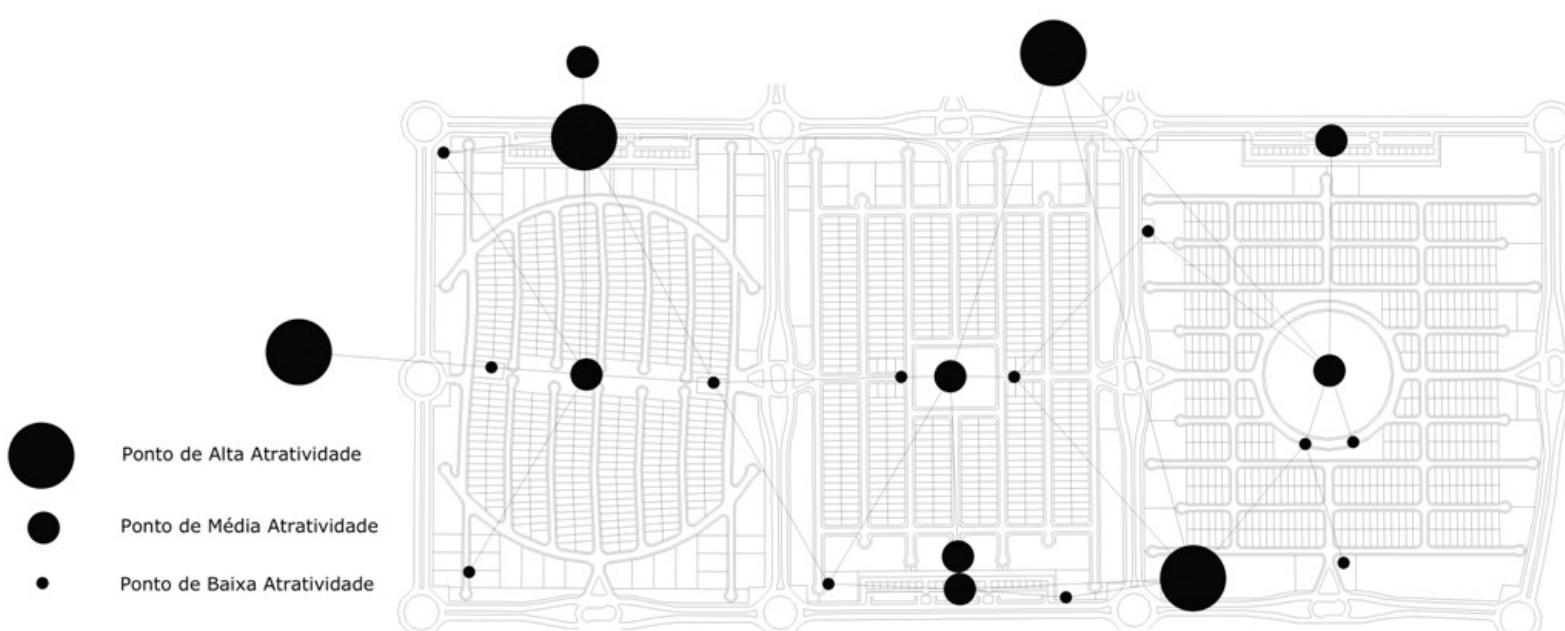

Fig. 90, Conec tividade e pontos de a trativida de na região central. (Fonte: autor, 2006)

As figuras 90 e 91 representam os pontos de maior atratividade e sua rede de conexões. Estas estão articuladas referenciando à integração entre cada uma delas, tanto no espaço como na complementaridade de uso, e pelo grau de importância que cada uma apresenta dentro dasquadras.

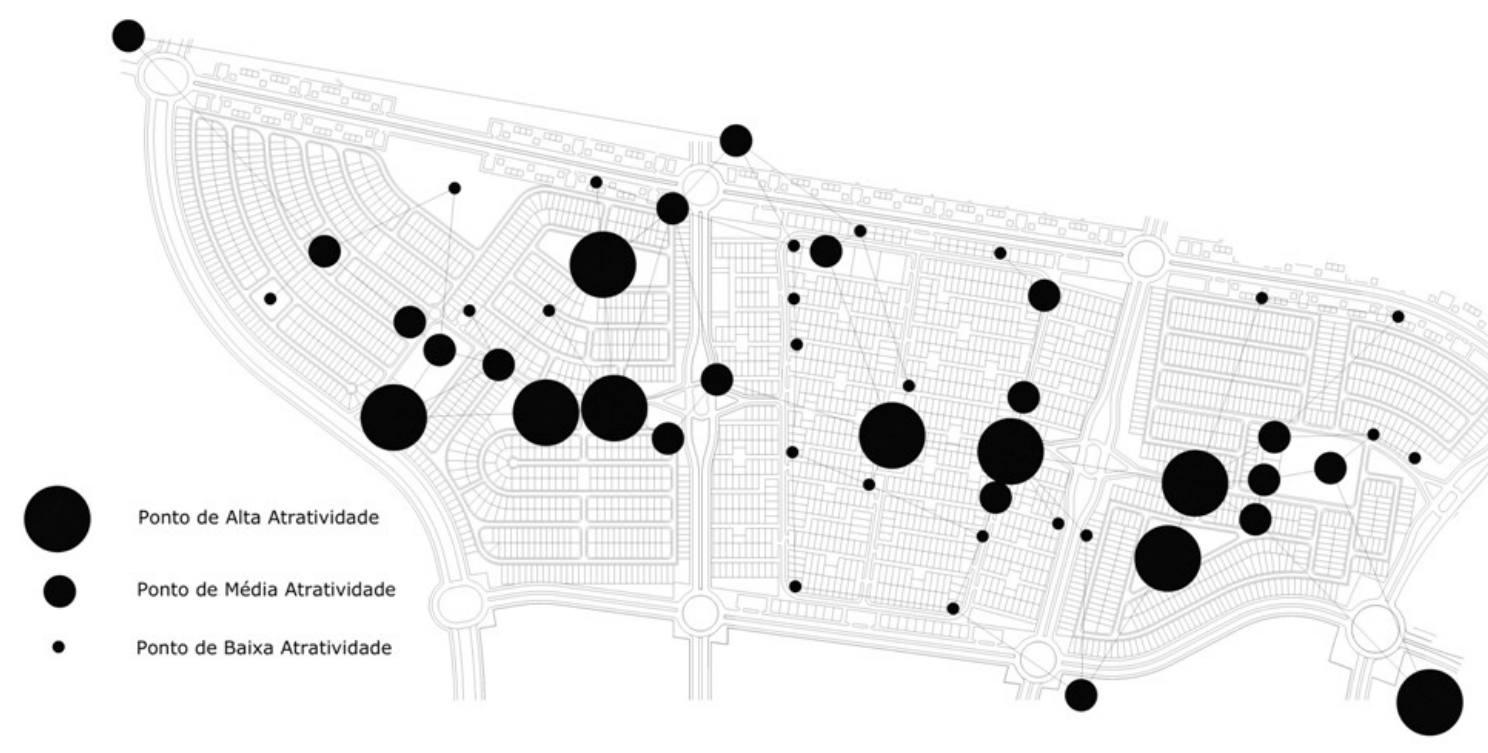

Fig. 91, Conec tividade e pontos de atrativida de na Vila União. (Fonte: a utor, 2006)

Nas três quadras centra is (Fig. 90), os principa is pontos de a tração são representados pelas centralidades do projeto urbano, como o comércio vic inal, as esc olas, as praças e as igrejas loca is. Esses ultra pa ssam seus limites, permitindo ligações com as unidades adjacentes, sempre condicionadas 
aos pontos de atratividades definidos pelo projeto. Mesmo havendo essa variável, essa pouca diversidade reduziu e limitou as suas conexões, principalmente quando confrontada com as promovidas na Vila União (Fig. 91).

A múltipla centralidade promoveu uma maior quantidade de ligações, principalmente nas novas áreas comerciais que surgiram nos acessos. Essas se conectam, formando um eixo horizontal entre os outros pontos de atratividade, resultando em uma estrutura em rede que gera novas possibilidades de uso. Essa distribuição promoveu mais vitalidade ao cotidiano dosmoradores, incidindo na esfera pública do espaço.

Na região central, o comércio vicinal apresenta problemas na forma de se conectar com o interior de sua quadra, dificultando sua integração. Essa incongruência espacial, configurou um dos principais enclaves projetua is da cidade, gerando espaços ociosos em meio a o tecido urbano. Na Vila União, tentou-se estabelecer as mesmas premissa s projetuais, porém, a sua conformação fez com que o comércio vicinal perdesse seu valor de a tra tividade, alterando sua configura ção.
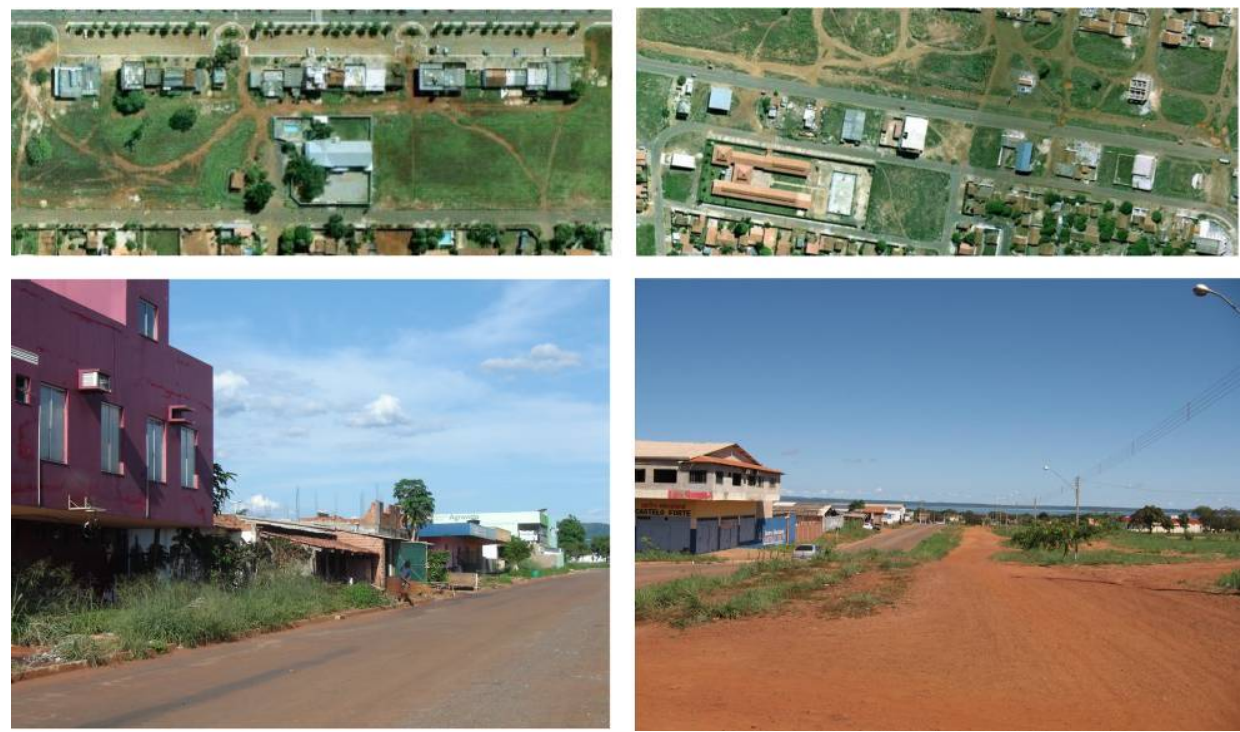

Fig. 92, Comérc io Vic inal da Arse 14 e Amo 32. Os equívoc os projetua is se repetem não integrando o comércio vic inal com a quadra, produzindo inscrições em meio ao espaço a inda não ocupa do para definir as conexões as essasáreas. (Fonte: a utor, 2006) 
Em contrapartida, os novos pontos e atração promovem uma integração entre o projeto urbano e as práticas sociais que o conformaram. Isso remete a aspectos de uma cidade tradicional, onde o uso do solo se molda em função do caráter axial de um deteminado eixo viánio. Outro aspecto questionado quanto à conectividade remete ao fato do projeto original restringir de forma intencional uma maior permeabilidade de veículos nas unidades de vizinhança. Os acessos só podem ser feitos por entradas junto às avenidas arteriais, ligando-as as vias loca is do interior da quadra. Tecnicamente foi um modelo adotado para organizar e direcionar todo o tráfego das avenidas expressas para as ruas intemas, e assim promover um maior ordenamento viário.

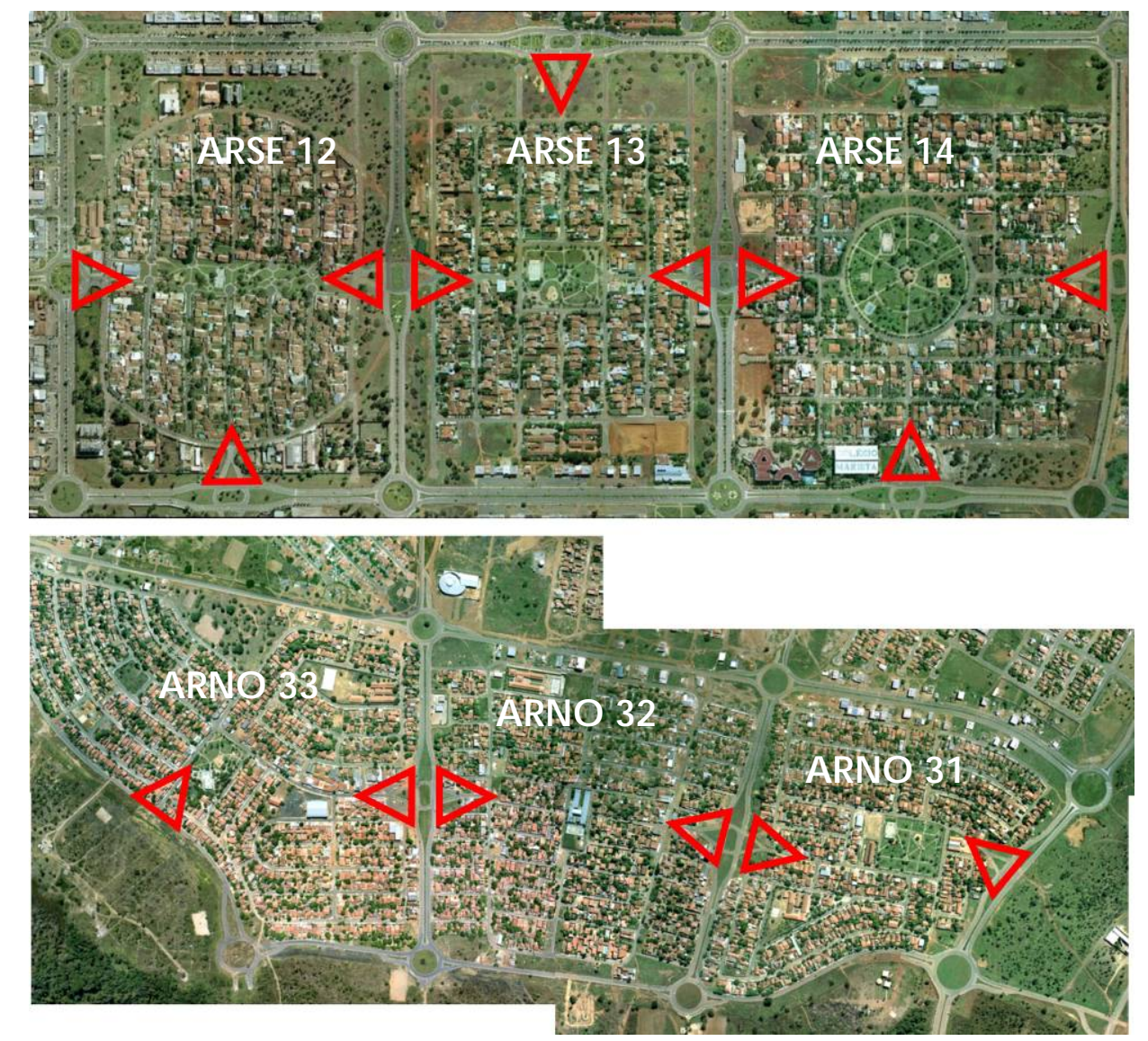

Fig. 93, Esquema de acessos nas quadras centra is e na Vila União. (Fonte: SEDUH, 2005)

A restrição ao acesso às quadras originou dois fatos que marcam a paisa gem das unidades de vizinhança. Na tentativa de restringir e separar o fluxo intemo, as partes frontais dos lotes se voltaram para as ruas intemas 
loca is, não possibilitando uma ligação direta com as avenidas. Isso criou a principal característica da paisagem de Palmas, uma cidade de muros, formatando seus os limites e perdendo o potencial de conexão direta entre os generosos espaços livres do plano. Outra conseqüência é o surgimento de caminhos e percurso feitos por carros e pedestres para facilitar o acesso às avenidas. Essa transgressão a o modelo de acessibilidade permitiu verificaras necessidades de conexão entre os eixos viários arteriais e as ruas locais, possibilitando uma maior permeabilidade e capilaridade, integrando-as ao plano (Fig. 94).
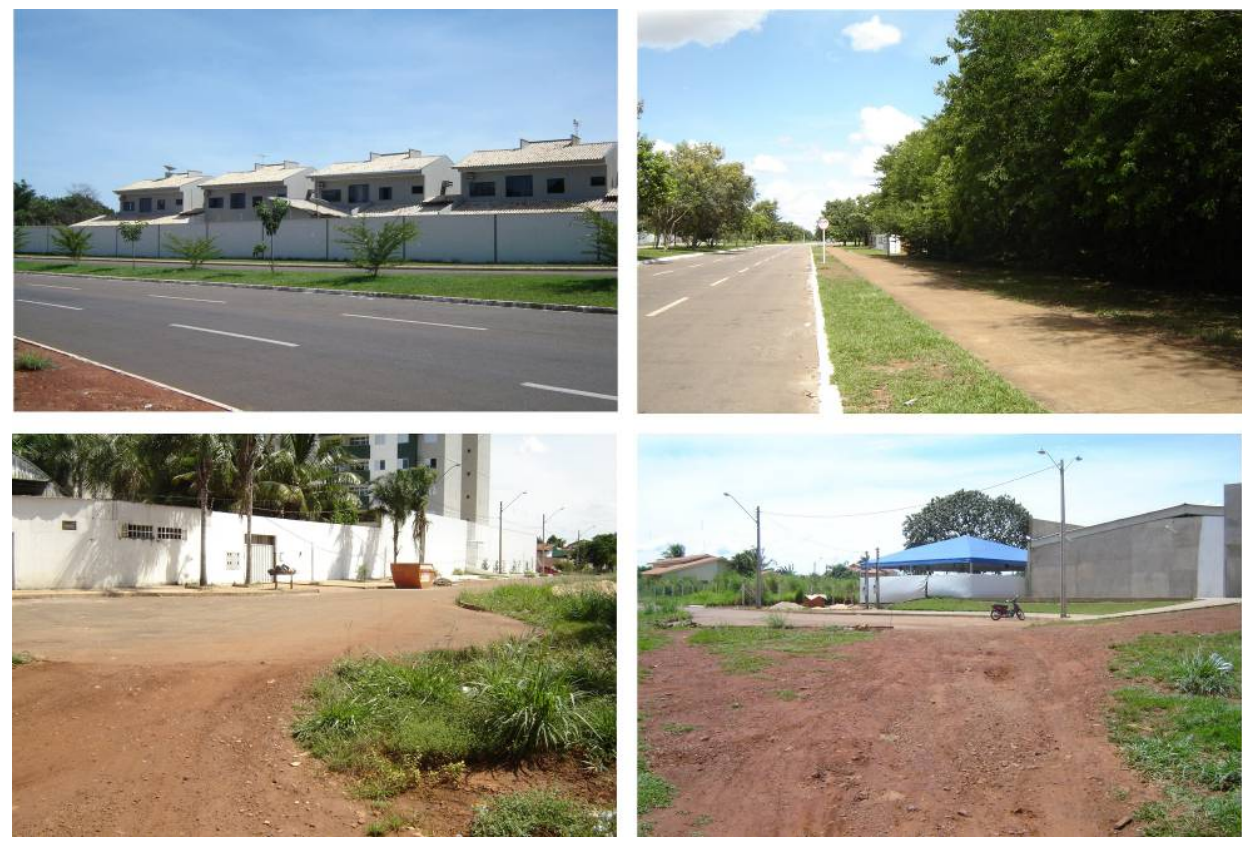

Fig. 94, Muros nos limites das qua dras: condomínio s horizonta is em lotes multifa milia res cada vez mais marcam a paisagem; tra tamento paisagístic o para camufla ros muros das residências. Dois pontos na quadra Arse13 onde se percebe caminhos realizados por automóveis. (Fonte: a utor, 2007)

A Fig. 95 apresenta um esquema axial da região central, com sua capacidade de conectividade, integração e assim inteligibilidade 29 . Percebe-se que o modelo de cul-de-sac interrompe a ligação das vias locais com o sistema viário da cidade, e faz com que essas tenham menor grau de inteligibilidade.

\footnotetext{
29 Inteligibilidade é entendida aqui como a correlação existente entre conectividade e integração. (Fonte: Holanda, 2006)
} 


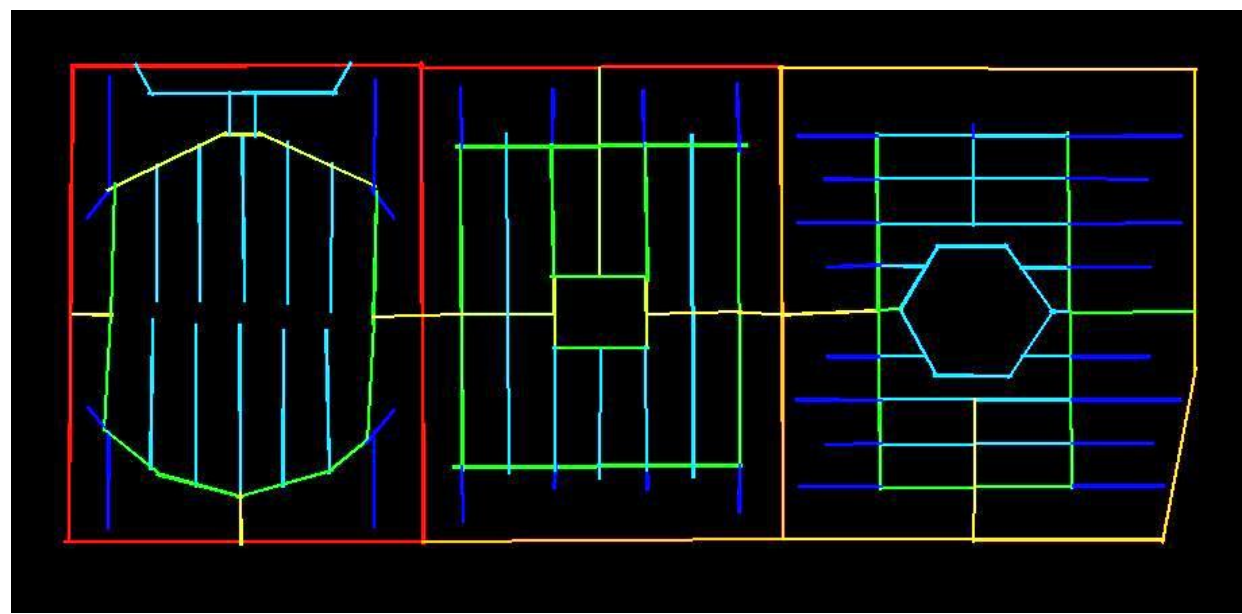

Fig. 95, Modelo de axialidade para as quadras centra is. (Fonte: a utor, 2006)

A Fig. 96 representa um esquema de conexões previstas pelo projeto e inscritas pelo processo de ocupação. As quadras da região central seguem o princípio de resenvar as ruas para tráfego preferencialmente local, porém percebe-se através de inscrições em alguns espaços, a necessidade de ligações entre o sistema local e o arterial. A quantidade de caminhos inscritos por pedestres e automóveis, tanto nas áreas privadas sem ocupação, quanto nas de propriedade pública, alteram a dinâmica espacial, porém, muitos fluxos, em verde, tendem a desaparecer à medida que os lotes forem sendo ocupados.

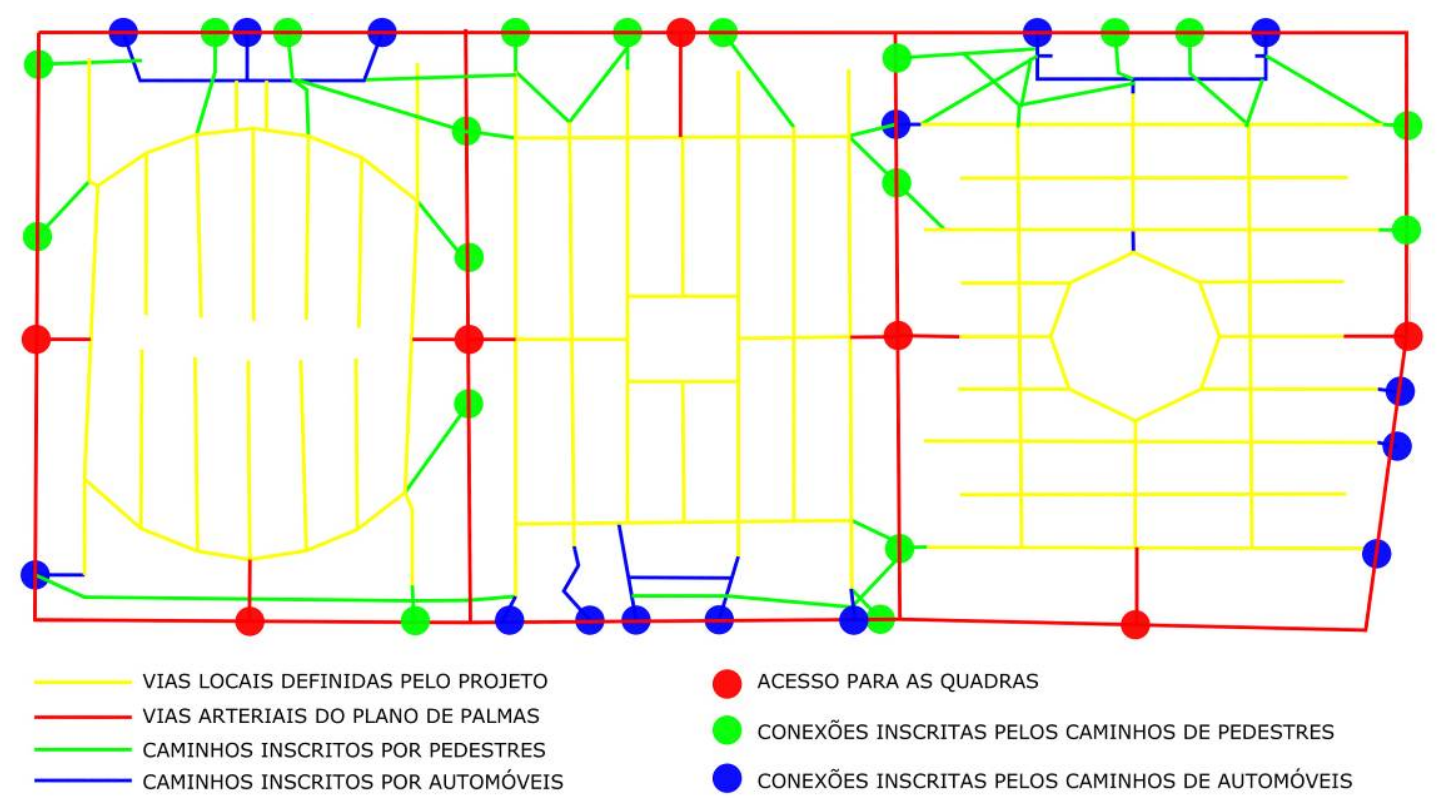

Fig. 96, Pontos de conexões na região central. (Fonte: autor, 2006) 
Jane Jacobs afima que uma das principais caracteństic as para trazer qualidade ao planejamento físico de um bairro, é fazer com que o tecido das ruas forme uma malha ma is contínua possível. As observações empínicas de J acobs e as análises matemáticas feitas pelos pesquisadores da sintaxe espacial, focam no mesmo ponto em épocase formas diferentes.

Cada fragmento é um lugar em potencial para a criação de novas conexões, gerando uma diversidade de fluxos que influenciam a dinâmica do cotidiano, demonstrando que a urbanidade não é fruto só de seu projeto, mas de seus limites, que se evidenciam nos processos socia is.
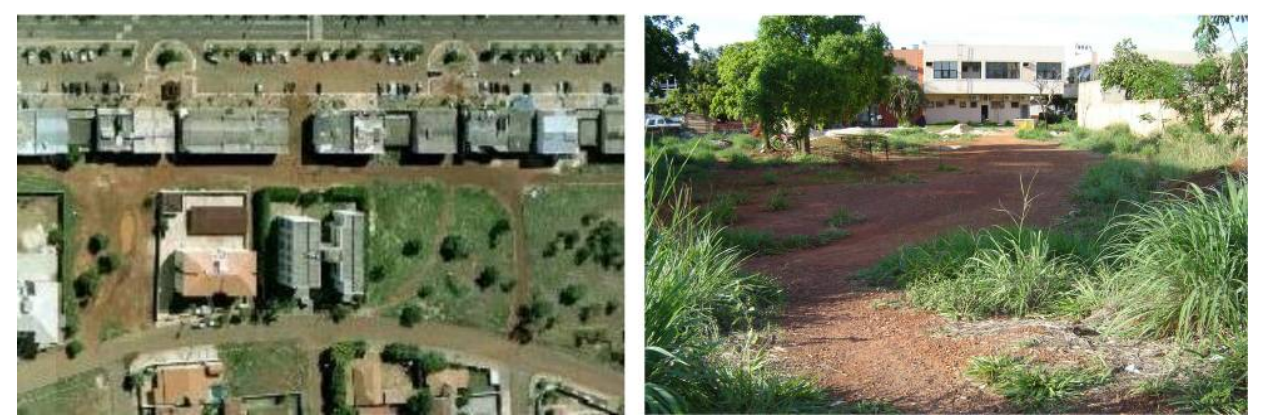

Fig. 97, Foto aérea do comércio vicinal da Arse12: a dificuldade de acesso da quadra para o comérc io e para a parada de transporte coletivo na avenida fez surgir uma rua atrás dos lotes e caminhos feitos em terrenos priva dos pa ra melhor a cessibilidade. (Fonte: SEDUH, 2005; autor, 2006)

A mesma ruptura ocorreu na Vila União, mas com um processo diferenciado que gerou outra confomação. Ao contrário das quadras centrais que apresentam três acessos, o projeto original para cada unidade de vizinhança limitou o acesso em apenas dois lados, o que dificultaria a inda ma is a conectivida de entre as a venidas a rteria is e a s ruas locais.

O projeto original da Amo 32, já apresentado anteriomente, previa uma diferenciação quanto à hierarquia de ruas, promovendo como conceito ruas de pedestres ligadas a uma perimetral intema. O principio projetual não se confomou como estipulado, e cedeu lugar a um fato exclusivo na cidade de Palmas: ruas intemas que se conectam com as avenidas arteriais. Este alterou a axialidade da Vila União como um todo, e formatou o modo de circulação por elas, distribuindo melhor os fluxos pela 
trama. A caracteństica colocada por Jacobs ocorreu na Amo 32, não pelo projeto, mas pela sua contra posição.
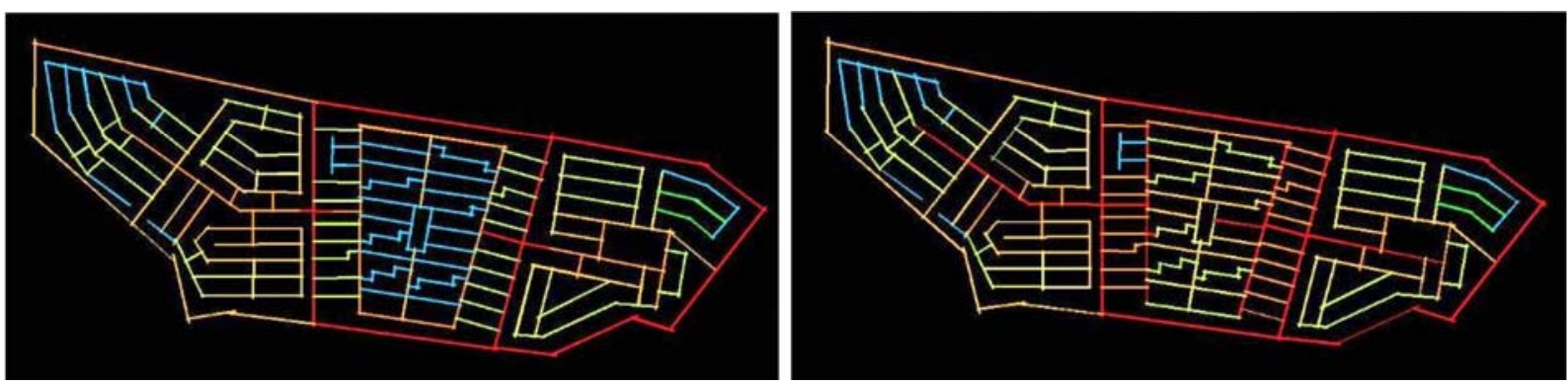

Fig. 98, Axia lidade do projeto original e como ela se encontra na atualidade. A integração da ma lha viária local com as via sarteria is possibilitou uma maior integração da malha urbana, proporcionando maior conectivida de da trama urbana. (Fonte: autor, 2007)

A Fig. 98 representa como seria a axialidade se o projeto original tivesse sido realmente concretizado, e como ele se coloca na atualidade. A ruptura não é somente no desenho, que excluiu as barreiras físicas entre esses dois elementos viários, mas de uma outra forma de ocupação do uso em Palmas. Tais alterações possibilitaram uma mudança na paisagem de muros da cidade. As esquinas dessa conexão promoveram também uma mudança na disposição da construção no lote, se voltando para as avenidas arteria is. A Fig. 99 demonstra esse encontro no espaço.

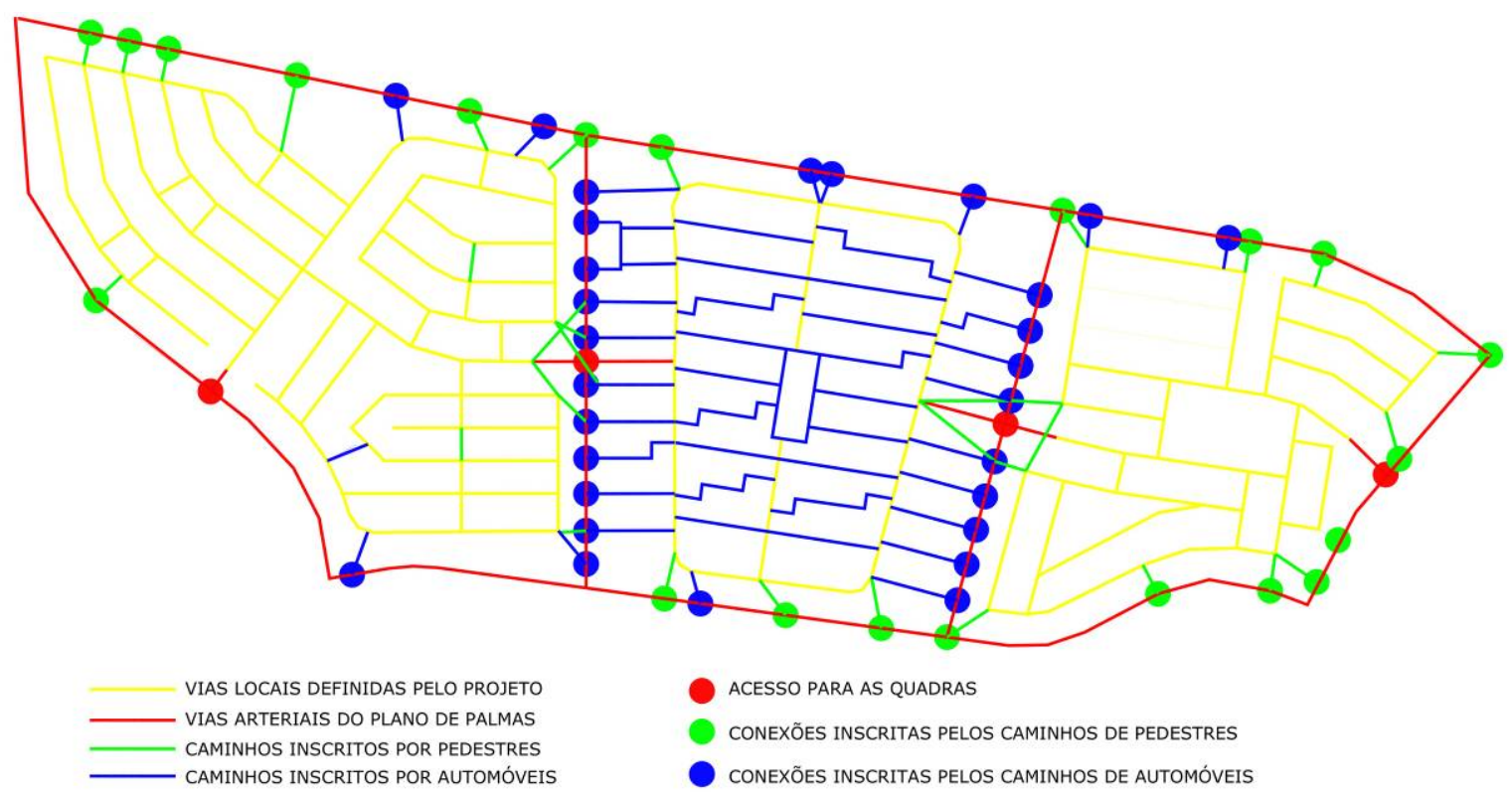

Fig. 99, Pontos de Conexão na Vila União. (Fonte: autor, 2006) 

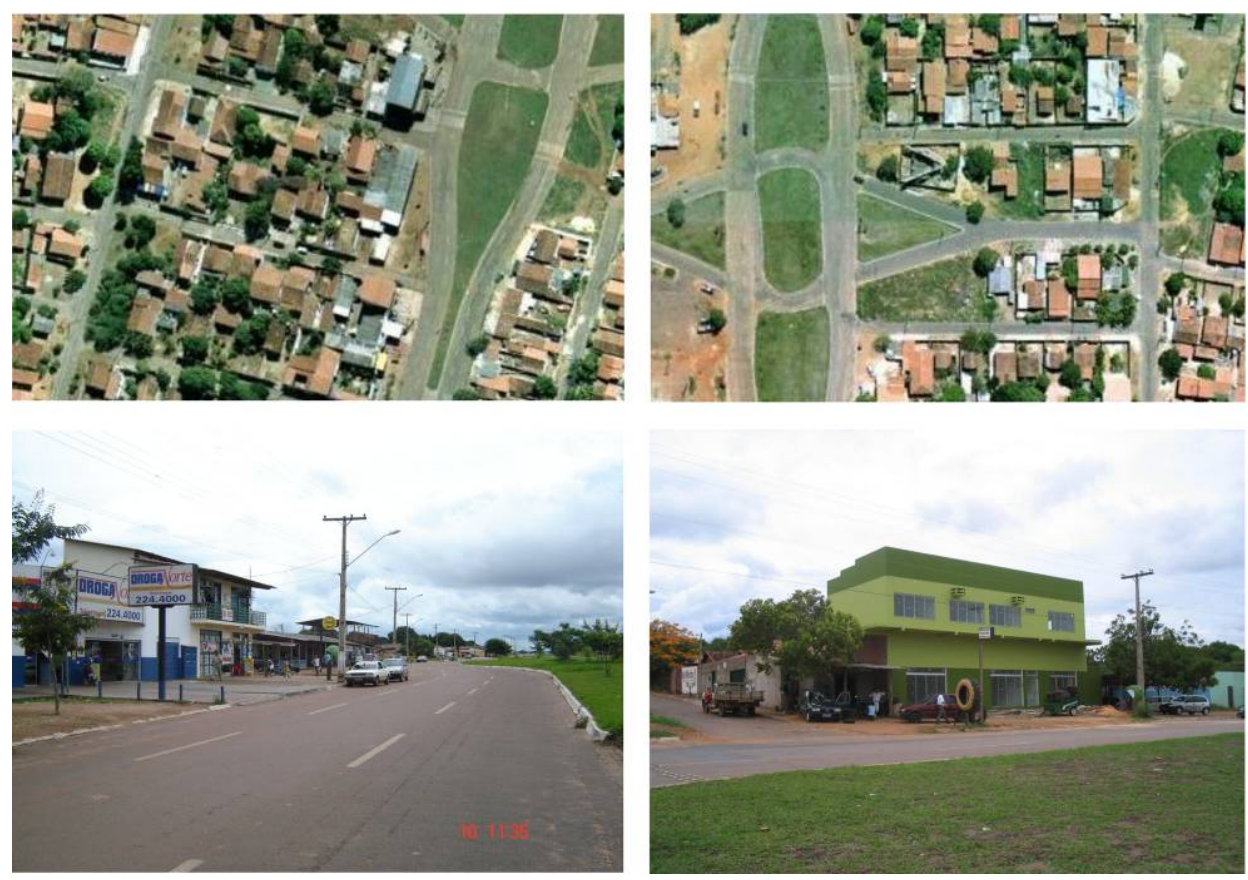

Fig. 100, Pontos de conexão entre as via loc ais e a avenidas arteria is. Nestes pontos a a rquitetura influenciou na conforma ção de uma nova paisagem e de uma nova dinâmica espacial. (Fonte:SEDUH, 2005; Autor: 2006)

Essa nova distribuição não alterou a hierarquia e a condição de ponto nodal dos acessos às quadras, constituindo-se como centralidades, porém demonstrou que uma maior quantidade de conexões diretas entre o interior e o exterior da quadra distribui os fluxos pelo espaço, aumentando o papel das ruas como o lugar de circulação e encontro. Muitas áreas de propriedade pública estão em meio a esses eixos, transfomando seus espaços, mesmo sem intervenção projetual, em lugares.
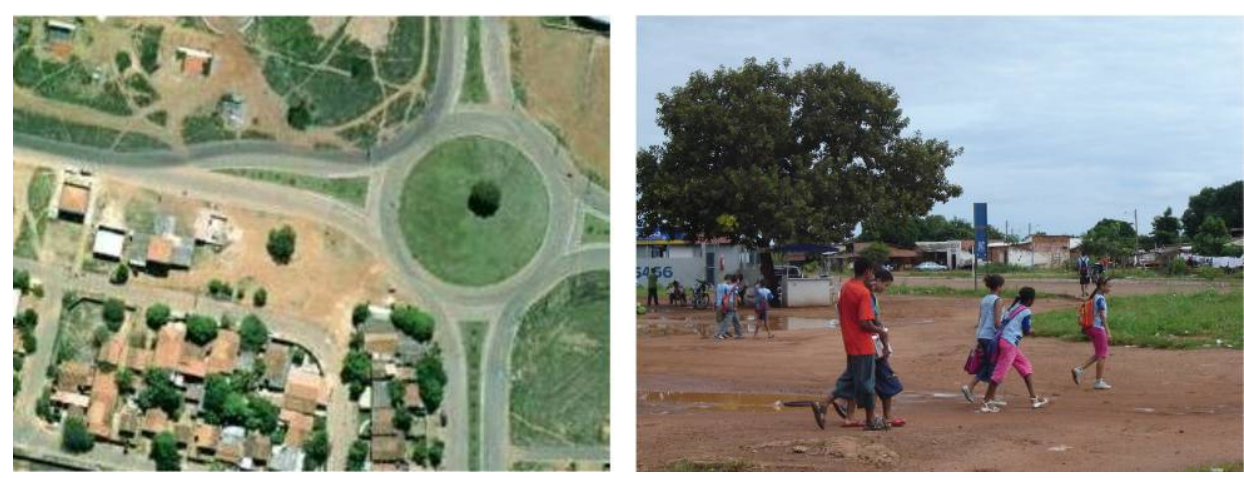

Fig. 101, Caminhos feitos por pedestres que acabam gerando pontos de concentração de mora dores. (Fonte: SEDUH, 2005; a utor: 2006) 
O projeto urbano não é abordado aqui como um elemento estático, inc apaz de sofrer a lterações, porém, ta is comporta mentos a nalisa dos na Vila União e em outras localidades da cidade, propiciam e suscitam a discussão dos limites destes como elementos estruturadores dos movimentos no espaço.

\section{Movimento e permanência no espaço urbano}

O modo de se movimentar em uma cidade é decisivo para se planejar a boa forma urbana. Na gênesis do urbanismo modemo o modo de circular pela cidade é determinante para a confecção não só da trama física, mas das tramas socia is que tecem as dinâmicas do espaço. Cria r centralidadese conectividade são desafios de um projeto urbano, que se transformam e são apropriados de modos diferenciados em função das caracteństicas e elementos que o compõe.

Os movimentos caracterizam o modo da sociedade se deslocar dentro de uma trama urbana, e também os fluxos do cotidiano, determinando os principais pontos de convergência e trajetos. Estes conferem à capacidade de um local abrigarpor um determinado momento uma parcela dessa sociedade.

O espaço livre, objeto das a ná lises desta subcategoria, é um elemento capaz de gerar fluxose permanências, porém nem sempre condicionados à qualidade espacial. Alguns lugares de maior circulação podem não apresentar urbanidade, o mesmo acontecendo com locais de permanência, porém, a capacidade do espaço livre em gerar vitalidade está ligada à sua sintaxe, ao sistema de tramas sociais, e a condição diversificada de usos. Jacobs afima que é a sua fluência e a confluência de trajetos, que fazem as vizinhanças constituírem combina ções de atividades, mesmo que essas áreas sejam predominantemente de trabalho ou de moradia. 
Os sistemas de espaços livres devem ser condiciona dos a um misto de usos urbanos, atraindo uma diversidade de pessoas e incitando a apropriação do espaço de propriedade pública. A multiplicidade de centros as promove. A coletividade em ambientes públicos vem gradativamente sendo substituída por uma esfera individua lista e segrega cionista no espaço.

Atualmente circular por uma cidade não significa necessariamente interagir com seu espaço urbano. Cada vez mais este se toma um eixo de ligação entre dois pontos ou mais, um local de passagem apenas, cenário da movimentação alienada à cidade. Esse quadro é mais presente quando não há o que interagir, como é discutido no livro Cidade de Muros, ocasionando o que Caldeira, em citação de Weinstein (1996), adverte sobre a desvalorização da esfera pública.

\footnotetext{
"A cidade é vivenciada como uma passagem através do espaço, com restrições estabelecidas pela velocidade e pelo movimento, e não pela condição estática dos sólidos, dos prédios que definem a experiência do pedestre nas cidades tradicionais. A indiferença resultante privatiza a inda ma is a experiência, desvaloriza o domínio público e devido ao tempo gasto em viagens, contribui para o isolamento." (CALDEIRA, 1996, p 332)
}

A urbanidade é aferida pela confomação de lugares, referindo-se ao conceito de Augé: identitários, relacional e histórico, que se formam nos espaços de propriedade pública, fator este que pode ou não estar liga do à qualidade projetual, mas principalmente como configuradores de pontos de encontro, do debate público, que culturalmente imprimem sua marca no espaço. Assim como afima Rosalyn Deutsche, espaço não é uma entidade, masuma relação.

Este capítulo é uma forma de demonstrar através das observações in loco como essas conexões criam uma rede de movimentos urbanos e como as centralidades são apropriadas e criam pontos de pemanência pela população.

A fragmentação de uma cidade em unidades de vizinhança não é um fator para a má qualidade urbana, pelo contrário, o seu conceito deveria possibilitar o fortalecimento de práticas sociais no espaço e da 
distribuição de equipamentos urbanos pela cidade. A forma como estão dispostos seus usos geram o grau de utilização do espaço, alterando seu o conceito original que é promover e fortalecer as interações socia is. J acobs refuta qualquer modelo que encare os bairros como auto-suficientes e introvertidos, fazendo alusã o a o conceito de unidade de vizinhança, por não promoverem as relações intimas que ela tanto ressalta.

Esse fortalecimento pode ocorrer em diferentes níveis e âmbitos. Usos mistos, múltipla centralida de e conectividade, são capazes de promover tais relações. A capilaridade do espaço permite uma intensidade e diversidade de fluxos que distribui as relações socia is no espaço livre.

Nas duas áreas de estudo, os movimentos e permanências interagem com o espaço e apresentam posturas semelhantes, porém, com uma intensidade e freqüência diferenciadas. As observações captaram os principais fluxos, mensurando as movimentações no espaço através dos caminhos percorridos pelos moradores nas quadras. As observações também mapearam os pontos de permanência, não separando por gênero e idade, mas apenas pela quantidade de pessoas que se encontrava em determinado ponto no espaço no instante da pesquisa. Para esse levantamento foram feitas observações na região central e na Vila União simultaneamente, em dias da semana e em peńodos do dia altemados, para possibilitar diferentes leitura se percepções desta incidência.

A Fig. 102 representa os levantamentos feitos em uma terça-feira à tarde, onde as condições climáticas se encontravam em tomo de $32^{\circ} \mathrm{C}$. Cada ponto em azul corresponde a uma pessoa e cada linha vermelha os principais caminhos percomidos, podendo ser por uma ou ma is.

Nas quadras centrais, existe uma predominância de movimentos verticais no sentido dos comércios vicinais e das paradas de ônibus, caracterizando uma hierarquia padronizada entre as residências e as avenidas Leste-Oeste. Mesmo havendo fluxos no sentido horizontal no horário avaliado, não há uma grande intensidade de trocas entre as quadras. Um ponto em comum ocorre: a praça é caminho de passagem para os 
moradores, servindo com eixo de conexão com os outros pontos de convergência.
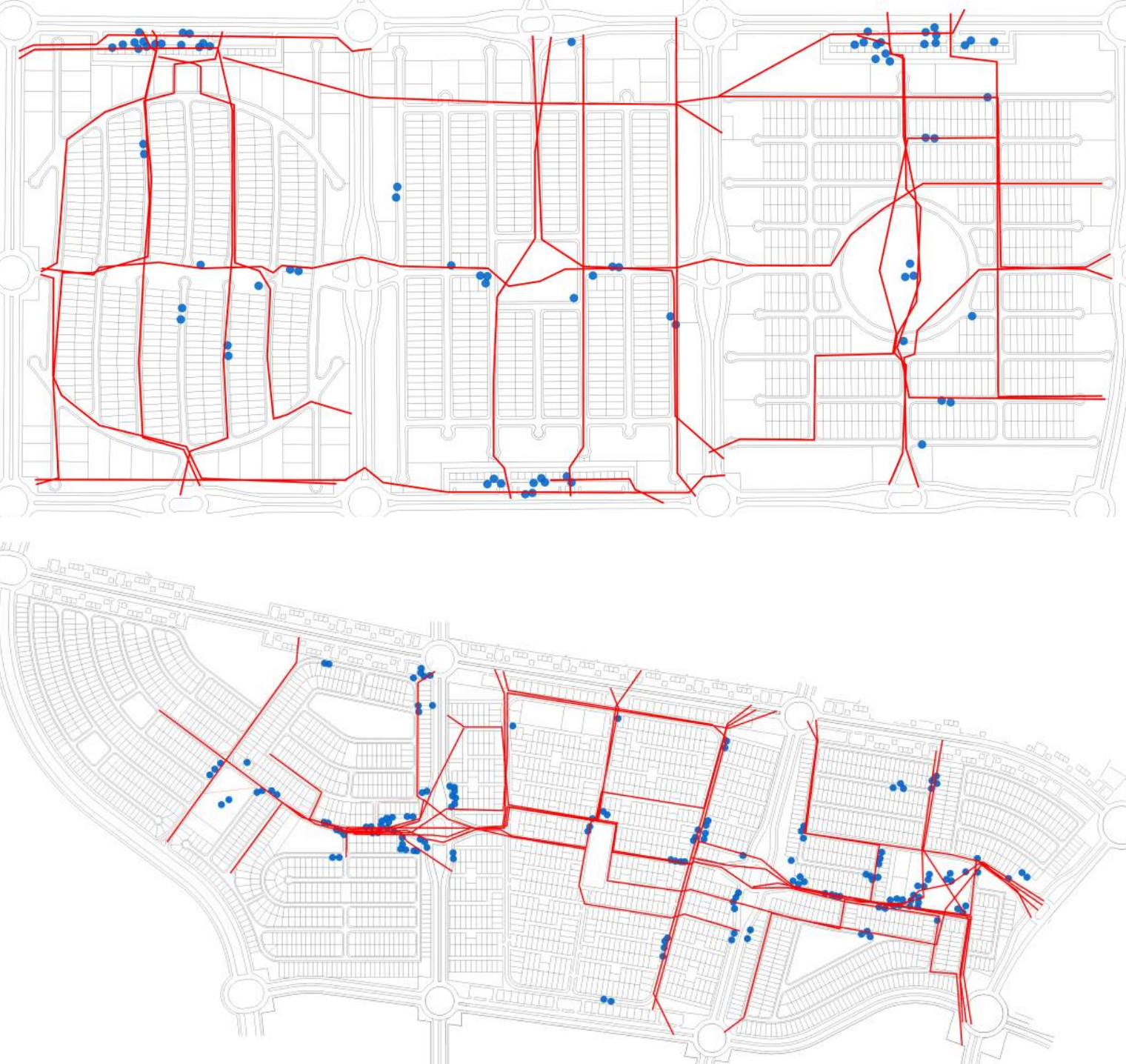

Fig. 102, Movimentose permanênciasna Área Centrala na Vila União - terça-feira à tarde. (Fonte: a utor, 2006)

$\mathrm{Na}$ Vila União os movimentos se caractenizam por uma nova hierarquia, conectando e produzindo os novos lugares nas áreas públicas. Em contraposição aos fluxos da região central, há uma troca maior no sentido dos eixos horizontais, ligando os centros de cada quadra e ramificando vertica lmente em direção às moradiase pontos de atratividade, como comércios informais, escolas, igreja e praças. A alteração dos usos do solo permitiu a conexão efetiva entre as três unidades de vizinhança, 
confomando nós urbanos nos acessos viários. Essa dinâmica permitiu a utiliza ção intensa dos trevos das a venidas, tra nsfomando-os em luga res.

Os pontos de permanência estão ligados a esses movimentos. O comércio é o catalisador em comum nas duas regiões. Nas praças e nos espaços livre, auxiliam na consolidação do encontro de pessoas. Para Jacobs a maior parte dos usos da diversidade depende direta ou indiretamente da presença de um comércio urbano abundante, oportuno e diversificado. (2000, p 162)
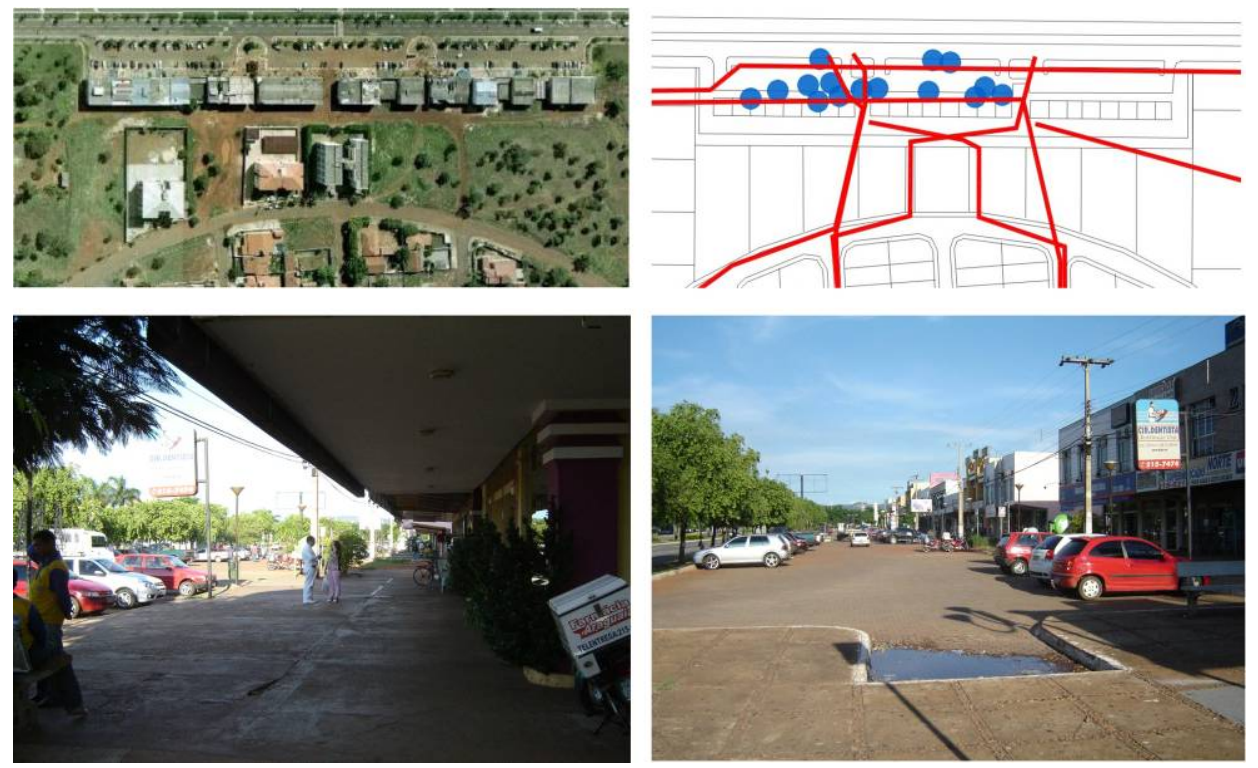

Fig. 103, Comérc io vic inal da Arse12 em uma terça-feira à tarde: lugar de grande movimentação e permanência de pessoas. (Fonte: a utor, 2006)

O comércio vicinal da região central concentra os pontos de permanência no horário avaliado. O setor comercial da Arse12 está se transformando em um pólo de serviço não só da quadra, mas da cidade, e se conforma como um lugarde encontro e de interatividade social.

No período avaliado, poucas pessoas se encontravam nas ruas e praças, devido ao forte calor no peńodo da tarde, onde as temperaturas a cima de $30^{\circ} \mathrm{C}$, desestimulam uma ma ior utiliza ção de a lguns espa ços livres. Assim, neste horário, as praças são utilizadas apenas como local de passagem. 

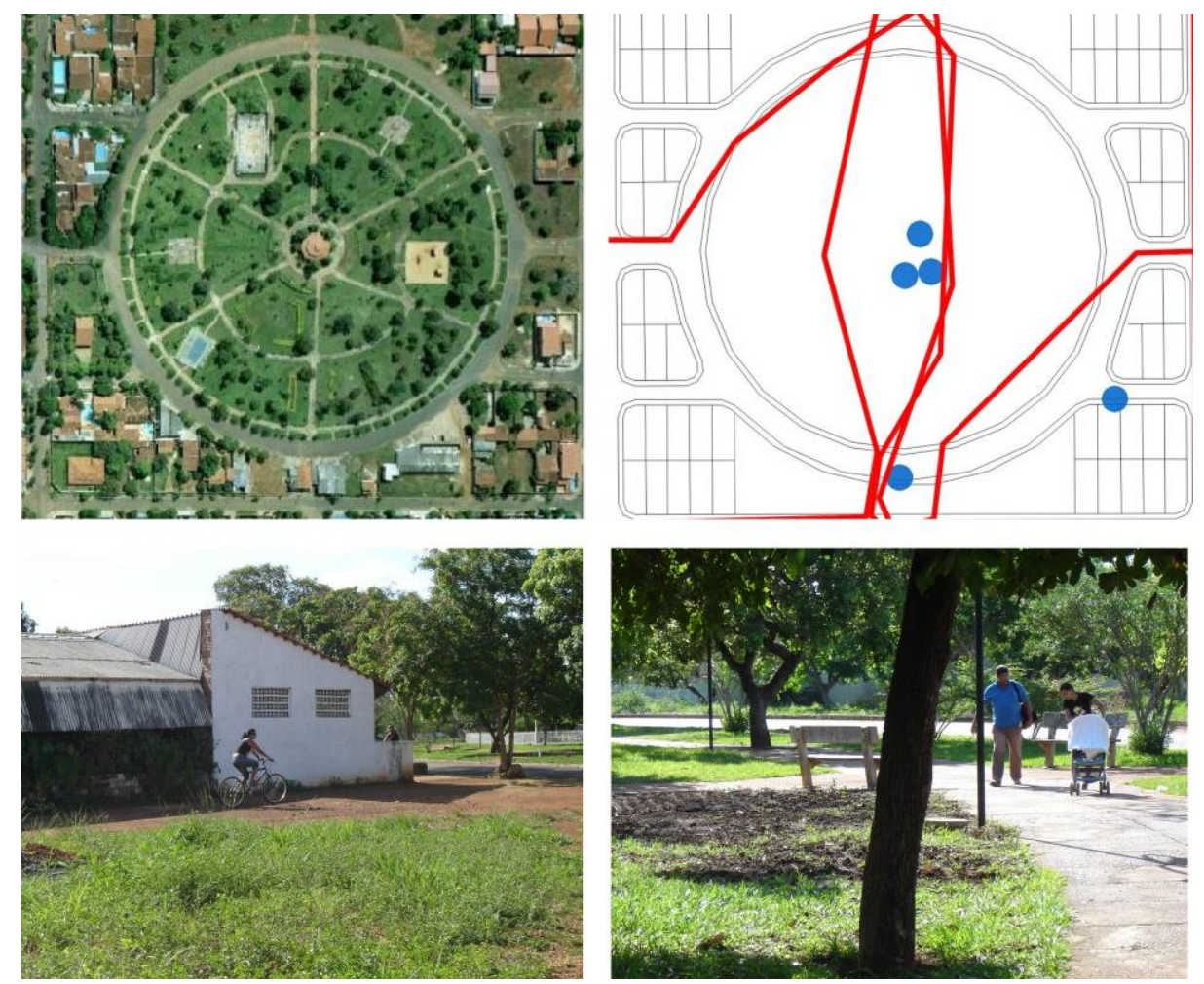

Fig. 104, Praça da Arse14 em uma terça-feira à tarde: local de passagem e de poucosfocos de permanência. (Fonte: autor, 2006)

A Vila União apresenta algumas particularidades, dentre elas o de ser a região mais populosa de Palmas, que faz com que ela possua diversos pontos de concentração de indivíduos nos espaços públicos. Se as quadras centrais ainda apresentam um potencial construtivo superior ao atual, na Vila União, a forma de ocupação promoveu sua elevada taxa de lotes ocupados. A capacidade do encontro aumenta, inserindo no espaço suas marcas.

Nas quadras centra is a ind a existem muitos terrenos a serem ocupados, diminuindo a densidade prevista de 300 hab/hectare para uma média de $30 \mathrm{~h} /$ hectare, ou seja, $10 \%$ do total previsto, com uma estrutura urbana bem consolidada. A densidade média na Vila União está entre 75 a 80 hab/hectare, também muito abaixo do esperado, porém distribuída de forma homogênea em seu teritório (Fonte: SEDUH, 2006). 

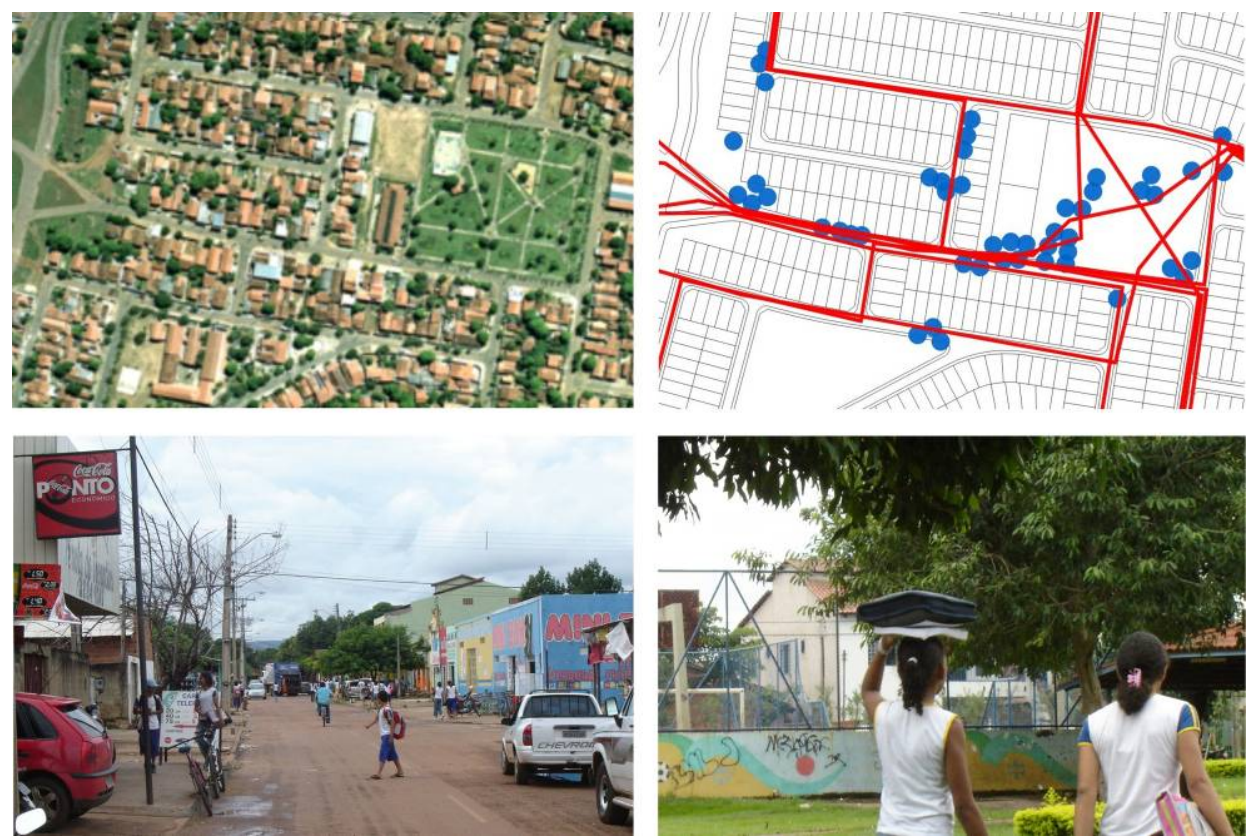

Fig. 105, Praça da Amo31(a primeira quadra da Vila União) terça-feira à tarde; grande fluxo de pessoas, pontos pemanência tanto na praça como nascalçadas. (Fonte: autor, 2006)
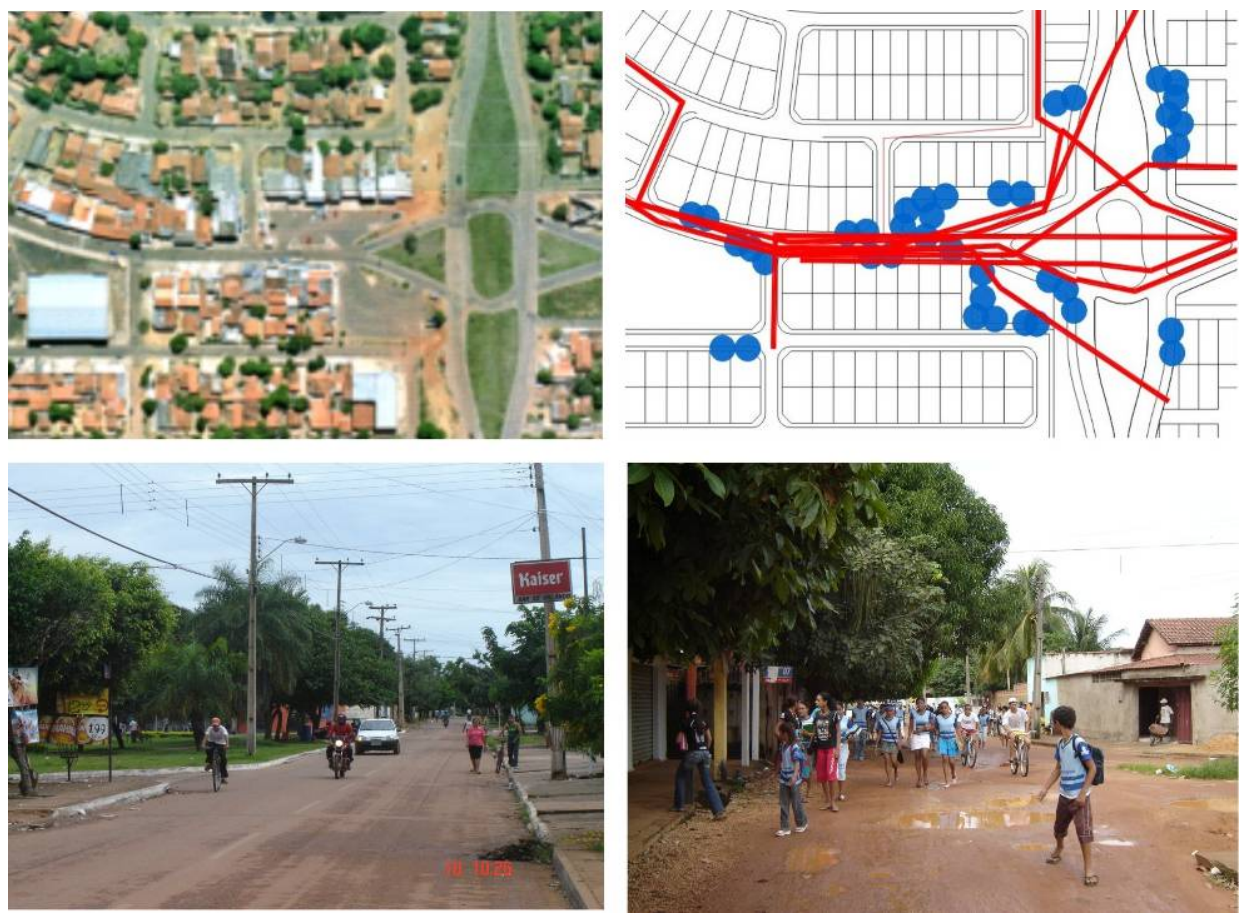

Fig. 106, Centro comercial da Amo33 terça à tarde: o grande fluxo de pessoas dá uma outra condição à esfera pública na Vila União. (Fonte: autor, 2006)

A apropriação de áreas concebidas como propriedade pública, mas que no projeto urbano se configuram mais como "sobras" do parcelamento, convergem como pontos de convívio e de passagem, intensificando os limites do projeto. Esses resíduos se tomaram lugares pela concentração de 
equipamentos urbanos junto a essas áreas, inscrevendo nestas pequenas fretas do desenho urbano locais de encontro, descanso e até mesmo de geração de renda para pequenos estabelecimentos.
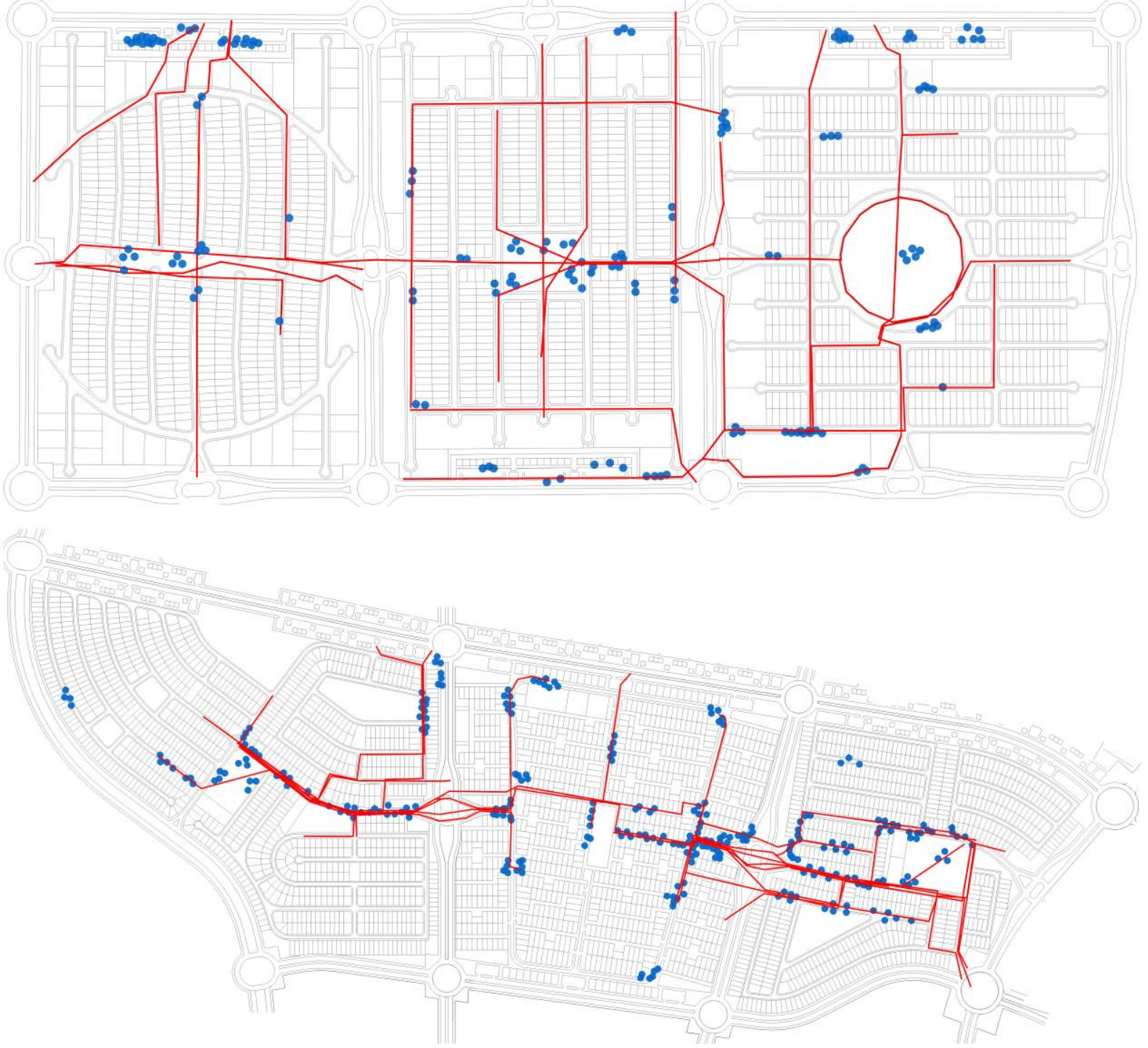

Fig. 107, Movimentose permanências na Área Central a na Vila União - quinta-feira no entardecer. (Fonte: a utor, 2006)

Os levantamentos efetuados nas duas áreas em uma quinta-feira no entardecer, apresentaram mais semelhanças do que diferenças. A quantidade de pessoas em movimento e que permanecem em algum local neste horário denota um ritmo diferenciado ao espaço urbano das quadras, possibilitando uma nova leitura das relações socia is e da paisa gem local. 
Se uma paisagem muda constantemente com a dinâmica urbana, o entardecer se caracteriza pela exaltação da esfera da vida cotidiana. O condicionante bioclimático é deteminante para a foma de apropriação dos espaços públicos na região norte do Brasil, porém para este trabalho, não foi feita uma medição deste em detrimento dos condicionantes físicos do espaço.
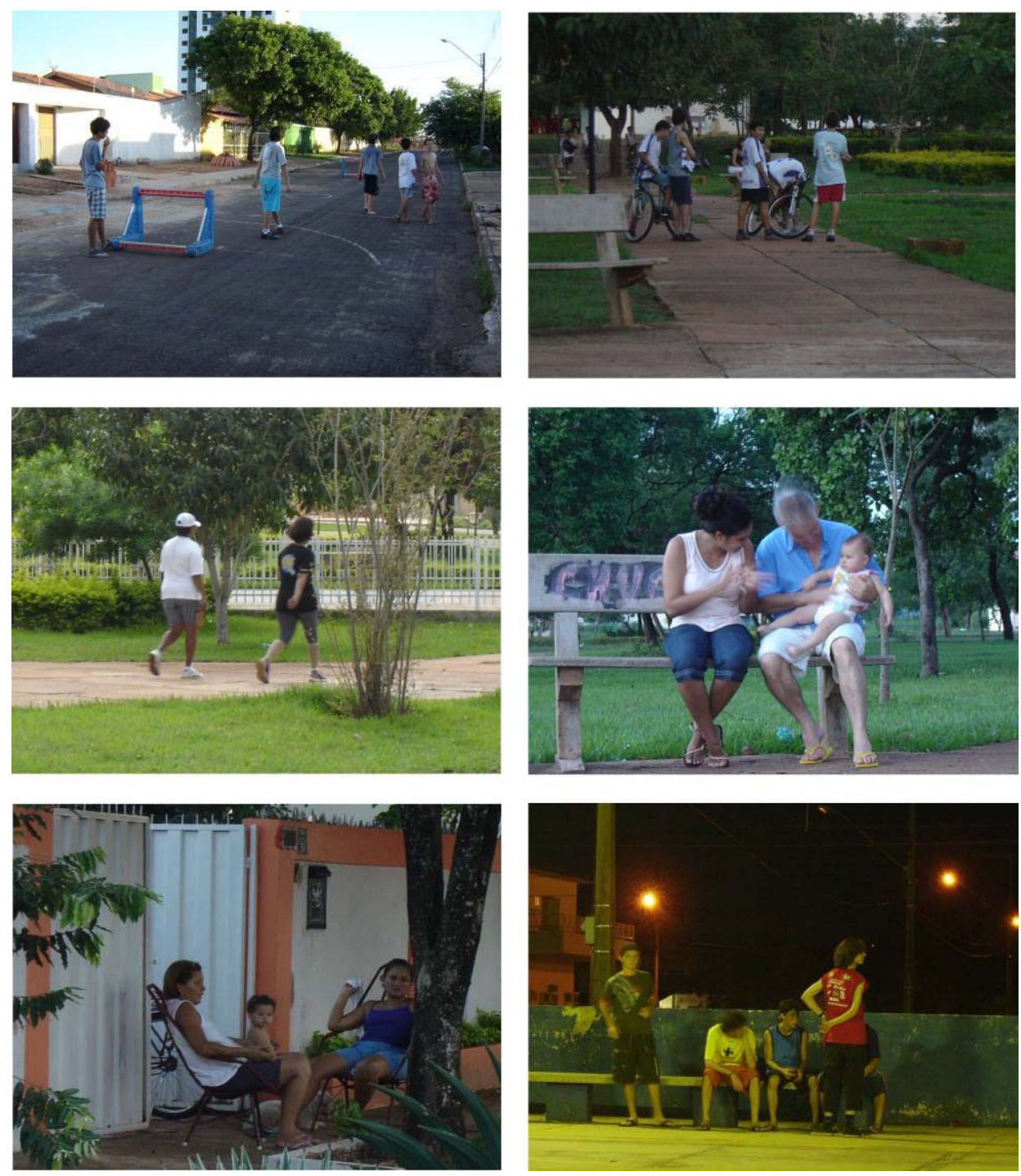

Fig. 108, Cenascaptadas na área central na quinta-feira no entardecere a noite. (Fonte: autor, 2006)

A cidade ganha um novo significado urbano a noite, não pelas luzes da cidade, mas pela possibilidade dos habitantes em se sentirem confortá veis em se a propriar do espaço público. Muitos fluxos correspondem às pessoas saindo do trabalho e as crianças voltando da escola. Nas duas 
áreas a nalisadas, esses se dissipam pela trama urbana, imigando os espaços públic os de pedestres.

$\mathrm{Na}$ região central, destaca-se novamente o comércio vicinal da Arse12 e da Arse14. A praça e as ruas da Arse13 apresentaram um grande número de movimentos de pessoas e pontos de permanência, para descansar, obsenvar o cotidiano, caminhar, andar de bicicleta ou praticar esportes. A praça da Arse14, pela sua dimensão, é utilizada por praticantes de comida e caminhada, apropriada no fim de tarde por moradores que a circulam.

Um importante ponto de concentração de moradores ocorre na praça da Arse12, diariamente ao entardecer. Nesta praça se localiza a igreja católica Casa de Maria, e missas são realizadas no horário das 17:00 às 19:00, possibilitando uma interação entre espaço construído e apropriação coletiva no espaço livre. A permeabilidade do projeto arquitetônico permitiu às pessoa s a ssistirem as missas de fora da igreja, na praça, possibilitando uma dimensão pública para este evento.
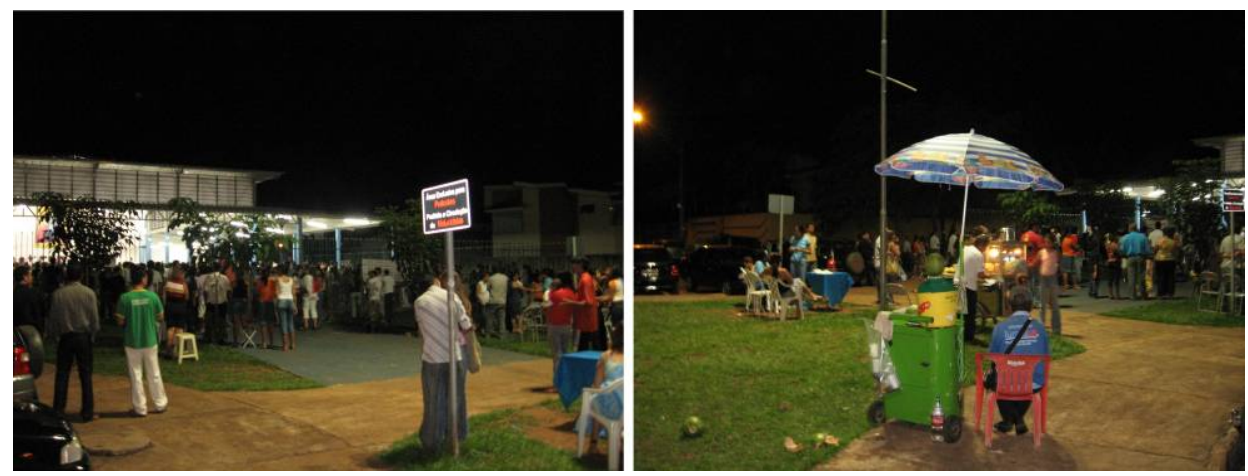

Fig. 109, Pessoas assistindo a missa na praça da Arse12. (Fonte: Daniel Pimentel, 2007)

Os movimentos e permanências na Vila União ocorrem, tanto no peńodo vespertino quanto ao entardecer, com a mesma intensidade e dinâmica, porém, os pontos de convergência se diferem. A entrada da quadra Amo 32 se tomou, neste período, o principal ponto de encontro dos moradores. Os bares, restaurantes e someterias, atraem os moradores da região noroeste da cidade, formando um centro de diversão e lazer para a comunidade. 
A presença constante de pessoas circulando pelas ruas, pode ser verificada também no domingo pela manhã na Vila União, quando os espaços públicos das outras quadras não apresentam a mesma apropriação.
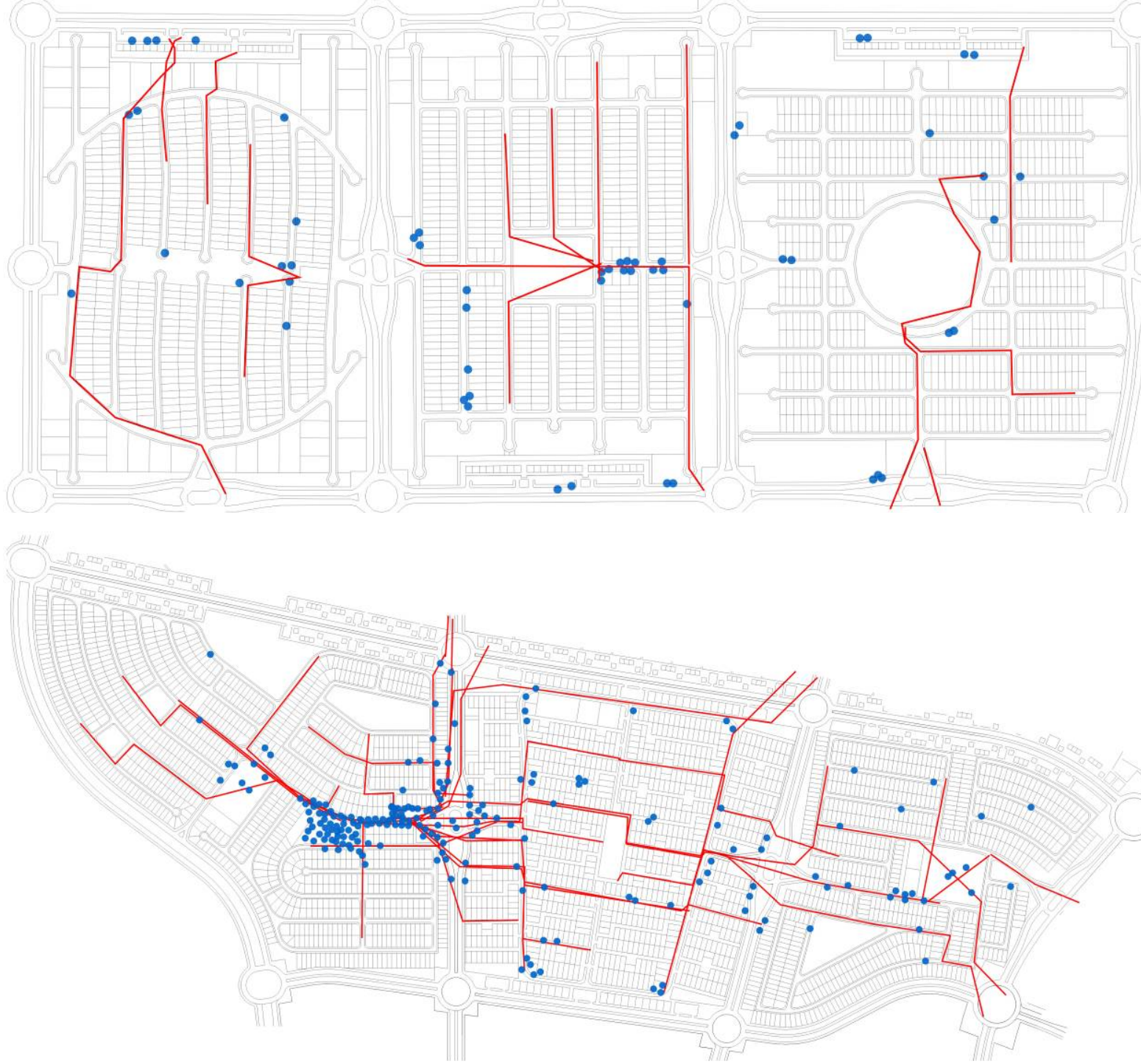

Fig. 110, Movimentose permanências na Área Central e na Vila União - domingo pela manhã. (Fonte: autor, 2007)

Domingo pela manhã é o peńodo que a Vila União vira uma centralidade da cidade. A vitalidade de seu comércio local e da feira que começa no sábado à noite e se estende até a manhã de domingo, atrai moradores não só de outras quadras da região noroeste, como de outras regiões da cidade. Junto com a feira, todo o comércio no entomo abre, 
atraindo a população, e ampliando os movimentos e permanências nessa parte da Vila União. Os fluxos levantados apresentam dois pontos de convergência, a feira e asigrejas que se distribuem pelas quadras.
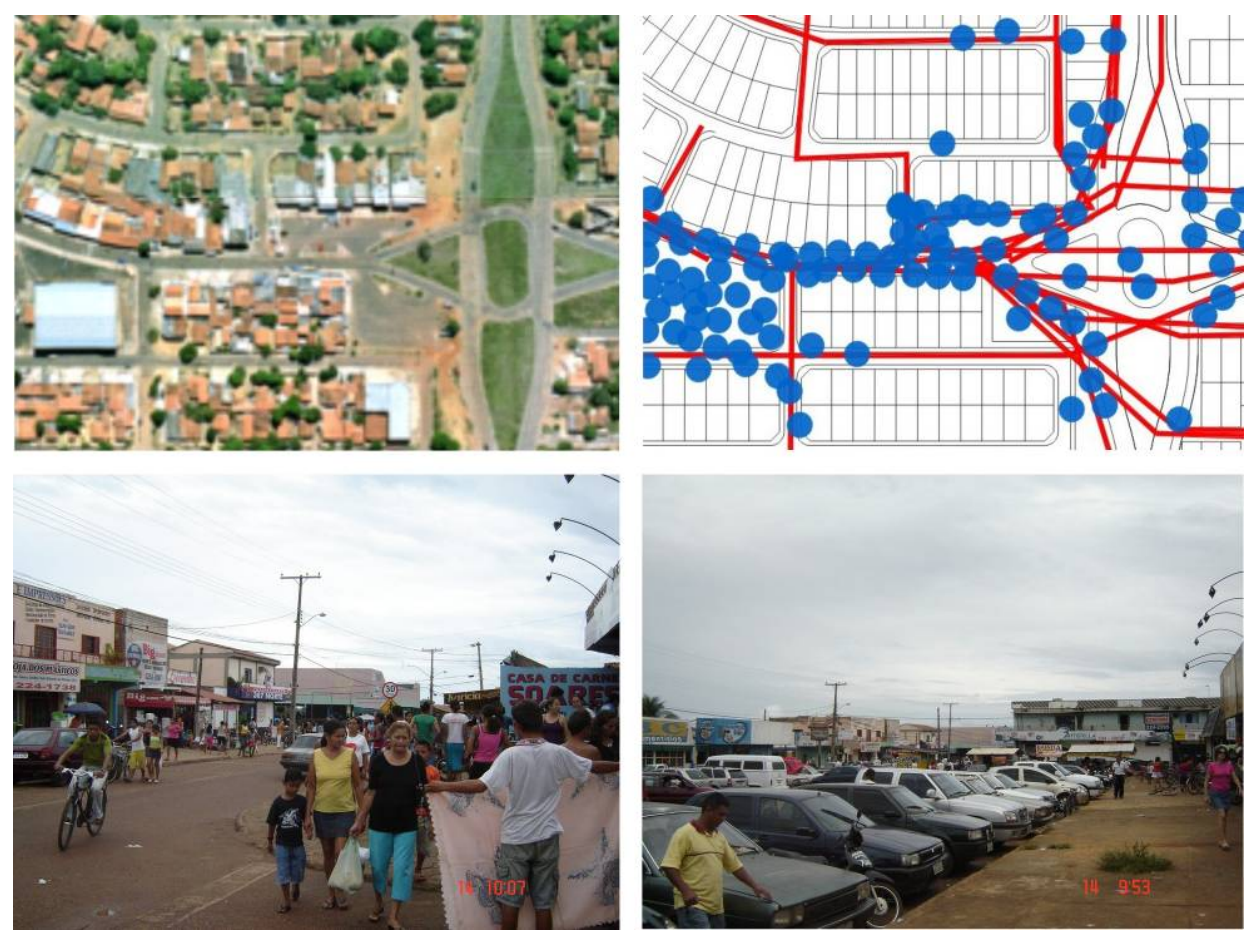

Fig. 111, Amo 33 domingo pela manhã - a feira e o comérc io atraem pessoas de outros pontos da cidade. (Fonte: autor, 2006)

As leituras feitas in loco para averiguar os principais caminhos percomidos pela população, e onde a pemanência era favorecida pelo contexto urbano, verificaram que a presença constante de pessoas nos espaços livresca racteriza a paisagem da Vila União. Essa dinâmica denota a sua identidade e o sentido de pertencimento, possibilitando a conformação de lugares.

"Os encontros interpessoais e o reforço das relações entre vizinhanças e bairros são práticas capazes de garantir a passagem de informações menos manipuladas, porque estão apoiadas na diversidade de interpretações de pessoas que se comunicam sem intermediários. Por outro lado, essas têm sido as únicas ações que possibilitam a superação de contradições históricas e a realização de transformações socia is e são, por isso a verdadeira ação cívica isto é, aquela de apropriação e construção da cidade pelos seus cidadãos." (KOHLSDORF, 1996, p 25) 
A forma urbana é um fator preponderante para a caracterização destes movimentos. Os sistemas de espaços livres encontram nos limites do espaço construído uma importante relação para a consolidação dos sistemas de fluxos na cidade e das trocas e interações das relações soc ia is.

\section{ReIaçã o entre Espaço Livre e Construído}

Quando Niemeyer profetizou a "esculhambação" que Palmas se tomaria por não deteminar um plano de nomatização edilícia, talvez ele não quisesse se referir apenas a arquitetura da cidade, mas a condição espacial deteminante que o construído, edificado, exerce sobre o espaço livre.

Interpretando a afimação, a esculhambação do espaço construído pode proporcionar também a do espaço livre. Mas como isso é possível? Outros processos que fazem com que ele seja "esculhambado"? Esculhambações a parte, o que este trabalho procura demonstrar é a dependência da urbanidade desta relação, pois a composição da paisagem é uma ação conjunta entre os diferentes elementos que se interagem no espaço urbano.

A relação entre espaço livre e construído não se restringe apenas a uma porcentagem, ou a algumas cifras, como costumam definir alguns planos. Caracterizar algumas áreas residuais de um projeto como espaços de propriedade pública, inspira algumas reflexões sobre como fazer a integração entre essas duas diferentes esferas, porém complementares, no urbano.

Uma importante relação está na capacidade de trocas que estas podem apresentar. Os limites entre uma e outra se caracterizam por particularidades fundiárias, fragmentárias e identitárias, que deteminam à forma de apropriação e pertencimento dos indivíduos. 
“O espaço construído tem uma dupla caracterização: de um lado, demarca as formas de apropriação do espaço urbano; de outro, estas marcas representam o elemento comum de mútuo pertencer entre o espaço e a coletividade que o dinamiza. Nesta dimensão, o design do espaço é sua a propriação e identidade social." (FERRARA, 2001, p 15)

Essas trocas, moldam e conformam as diversas interações socia is que compõe à paisagem urbana. Em Palmas o espaço livre é identificado pelas grandes praças, avenidas, canteiros, parques, que em tese deveriam promover a urbanidade, porém, a dissociação entre essa estrutura urbana, com a edilícia, interferiu nas dinâmicas promovidas pelo cotidiano que constituem parte da paisagem da cidade.

“O desenho urbano não deve ser o desenho dos edifícios ou fatos construídos, mas o desenho da estrutura, o desenho daquilo que une e relaciona os diferentes elementos morfológicos ou as diferentes partes da cidade." (LAMAS, 1993, p 125)

A diversidade de espaços que formatam o tecido urbano não catalisou suas potencialidades para a constituição de um ambiente com interações. Para Caldeira (2000, p 302), a qualidade do espaço construído inevitavelmente influencia a qualidade das interações sociais que lá acontecem. A configuração destes em Palmas representa uma conquista para o urbanismo sob a ótica de um sistema pensado para diversas finalidades, porém o excesso de espaço livre não representa necessa riamente qualida de.

Enquanto sua escassez em algumas cidades tradicionais promove soluções e apropriações inusitadas, e reveladas pelas relações socia is, em uma cidade planejada, o excesso promove apropriações nos limites entre o projeto e a condição social que se forma com o desenvolvimento da cidade. Conceber e formatar um sistema de áreas livres não implica necessariamente na transformação destes em luga res com qualida de.

A qualidade do espaço livre depende mais de sua relação com as diferentes formas de arquiteturas, e dos sistemas que se criam através dela, do que propriamente da quantidade de áreas especificada por leis ou 
projetos. A identidade dos espaços públicos abertos provém intensamente da maneira de ser, freqüência e mistura dos tipos de edifícios existentes. (KOHLSDORF, 1996, p 149)

A cidade de Palmas perdeu uma grande oportunidade de experimentar modelos que enfatizassem essa questão. Ao invés disso procurou definir as "áreas públicas" através de porcentagens para: área livre, área verde e área de lote. Isso definiu a divisão entre propriedade pública e privada, interferindo não somente na dimensão de sua apropriação, mas na relação entre o espaço construído e livre da cidade.

"Public space is another democratic concept, one that is central to discourse about cities, where it is used to support a cruel and unrea sonable urbanism." (DEUTSCHE, 1998, p 02)30

Condicionar espaço público a do público pode requerer mais do que especificações. Este fa to ocorre em todas as regiões do plano, desde a área central até as unidades de vizinhanças, local onde as interações sociais ocorrem em outra dimensão. Os limites impostos pela distinção de propriedade, caracterizam as influências sobre sua esfera pública.

As quadras das regiões de análise apresentam aproximadamente as mesmas estruturase coeficientes de á reas livres. O relevo mais pla no da área central possibilitou um projeto urbano mais retilíneo e padronizado, enqua nto que as quadras da Vila União apresentam maior variedade de formas e desenho de espaços livres, proveniente do declive em relação a o fundo de vale que as separam da área central.

A Fig. 112 representa a figura fundo dos espaços edifica dos e espaços livres nas quadras centrais. Em azul estão os lotes particulares, uni e multifamiliares, comércios, e instituições como igrejas e escolas. Há uma disposição do projeto em concentrar no meio dasquadras, isoladas, grandes áreas livres destinadas a praças. Cada miolo de quadra recebeu uma forma diferente, adequando-se o traçado do projeto.

\footnotetext{
30 Espaço público é outro conceito democrático, que é central para o discurso sobre cidades, onde é usada como suporte para um cruel e iracional urbanismo.
} 


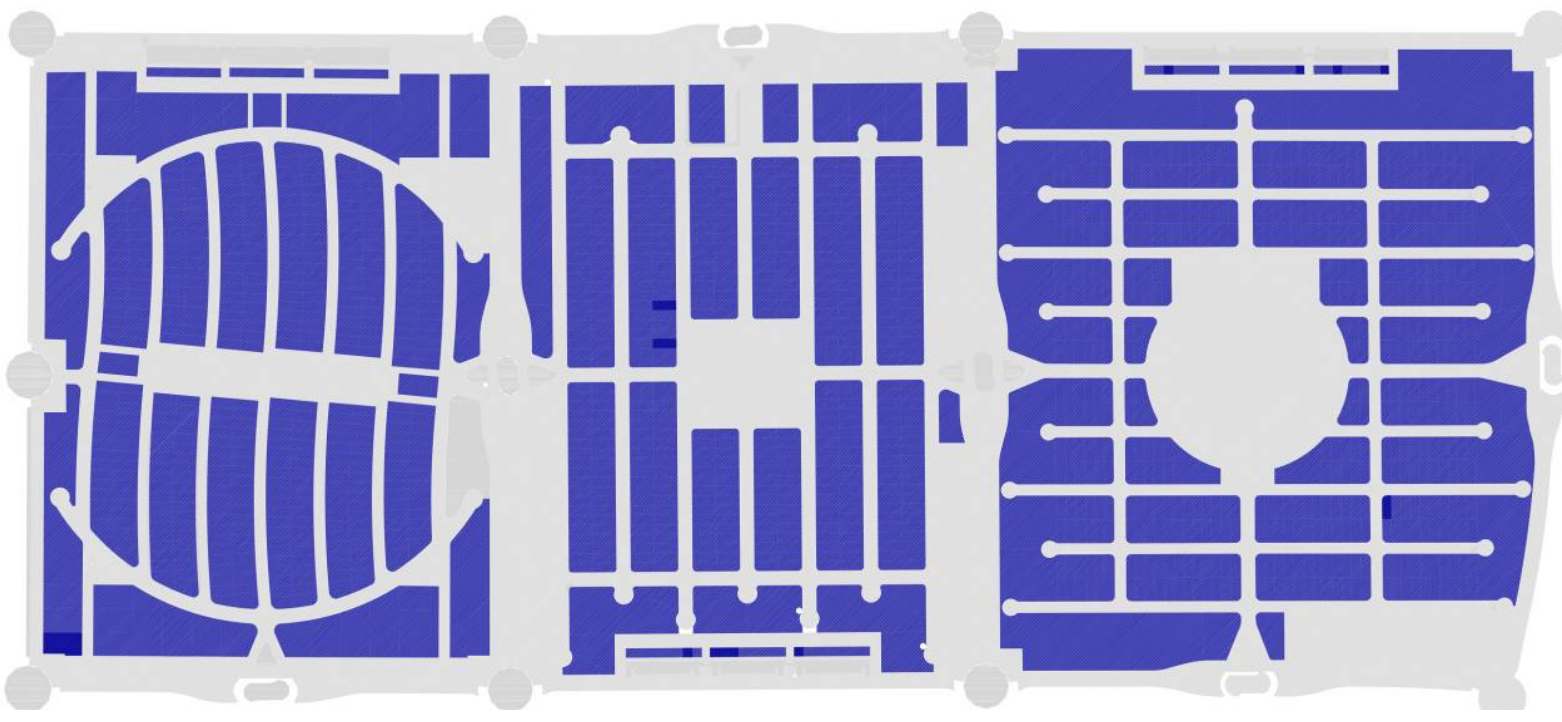

Fig. 112, Espaç os priva dos e espaç os livres das qua dra s centra is. (Fonte: a utor, 2006)

As quadras da região Arse apresentam uma maior legibilidade e continuidade do projeto urbano. O traçado ortogonal e as ruas com cul-desac as caracterizam, porém cada quadra apresenta uma particularidade que a identifica: a Arse12 tem a praça em meio ao parcelamento que divide a quadra em duas partes semelhantes; a Arse13 tem ruas paralelas que se conectam a praça central; e a Arsel4 tem uma grande praça circular como principal referência espacial. O tamanho da praça da Arse14 é desproporcional para o seu contexto, não se integrando ao restante da malha urbana da quadra. A concentração da porcentagem necessá ria de área verde nesta praça, a fez um marco urbano importante, porém a falta de integração com um espaço construído mais envolvente a fez perder força na consolidação desta como um espaço da urbanidade (Fig. 113).
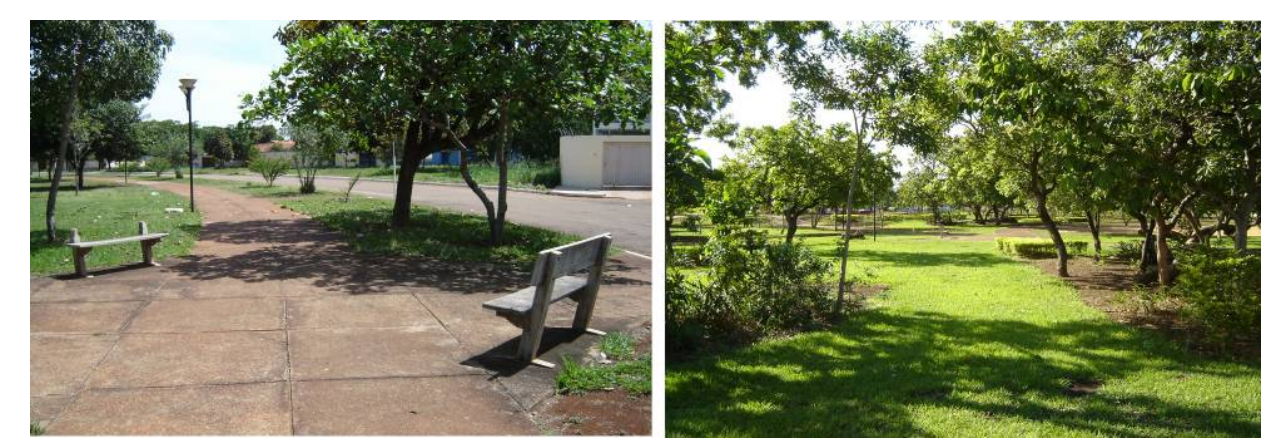

Fig. 113, Praça da Arse14: a falta de interação com o espaço edific ado não potencializa a sua qualidade espacial. (Fonte: autor, 2006) 
Projetualmente, os sistemas fechados foram adotados para promover uma maior privacidade de cada unidade de vizinhança, condicionando as ruas intemas como espaço reservados a o uso local. Esse modelo Palmas, não fragmenta e aumenta o senso de privacidade nas unidades de vizinhança. A segurança das ruas locais que uma proposta como essa idealiza, poderia ser alcançada por outros artifícios do desenho urbano. No item anterior, a estrutura de malha aberta que se formou na Amo 32 resultou em uma condição urbana benéfica para a consolidação da esfera pública do espaço na Vila União.

A relação entre a esfera pública e a privada é uma das principais questões do urba nismo contemporâneo. Em Palmas, há uma distinção clara em definir o que é área pública e área privada pelo projeto fundiário. A premissa de custear a cidade através da venda dos lotes pertencentes ao estado, influenciou no modelo de parcelamento urbano. Em Brasília, principal alvo de crítica a o urbanismo do movimento modemo, o modelo de parcelamento da superquadras permite um livre transito pelo espaço, dando-lhe uma outra dimensão pública. O plano de massas de Brasília não moldou somente a paisagem e a arquitetura, mas também as interações socia is resultantes da conexão entre espaço edifica do e livre.

\footnotetext{
“A primeira condição consiste em conceber o espaço público não apenas como um espaço dotado de uma forma precisa e prédeterminada, mas sobretudo em fazer com que seja esta forma o que comanda a disposição dos espaços privados e ordena os objetos a rquitetônic os." (HUET, 2001, p 147)
}

Na visão dos planejadores, em cada quadra projetada, buscou-se aplicar princípios de um urbanismo contemporâneo, com a criação uma espacialização urbana equilibrada. A imagem de um espaço urbano com qualidade foi fundamental para atrair moradores de todas as regiões do Brasil. É importante frisar que pelo plano original, as casas e edifícios não deveriam ter muros na frente dos lotes, e as divisões laterais deveriam ser feitas com cerca viva. Isso não é nenhuma utopia urbanística, mas as transformações cultura is que ocorreram, moldaram uma outra paisagem. 
Muros foram construídos, fechando não somente as frentes dos lotes, como os fundos que dão para as áreas públicas junto às avenidas, e fragmentando ainda mais as quadras, tanto na acessibilidade como na sua visibilidade.

Essa ruptura do conceito original transfomou os ritos do cotidiano. A quantidade de muros em Palmas pressupõe que a dimensão privada prevaleça na vida cotidiana dos moradores das quadras centrais. Os fluxose a apropriação do espaço foram demonstrados no item anterior, onde pontos de permanência, sejam nas ruas, nas áreas comerciais ou praças, ainda são reduzidos, proporcionalmente à quantidade de espaços públicos nas unidades de vizinhança.
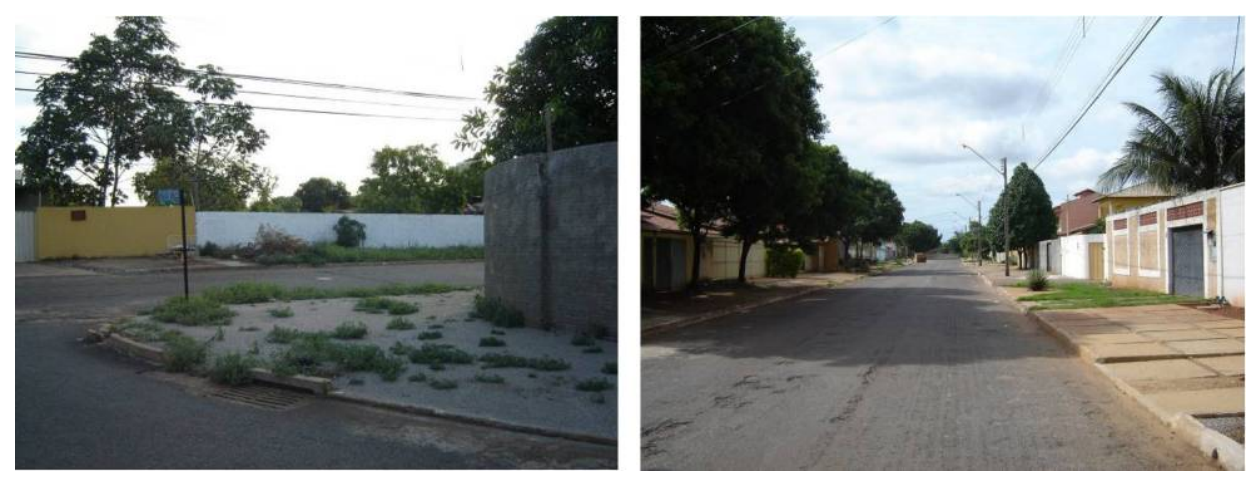

Fig. 114, Muros dos lotes residenc ia is que limita m o espaço público do priva do, e constituem a paisa gem das unidades de vizinhança na cidade. Essa configuração dific ulta as relações entre espaço construíd o e espaços livres. (Fonte: Autor, 2006)

A idéia de espaço público na cidade ainda está ligada à praça do bairro e áreas verdes. As próprias calçadas são apropriadas de foma privada, com canteiros, barreiras físicas, com vegetação dispostas sem qua lquer critério espacial, pisos ausentes e irregulares, problemas comuns às cidades brasileiras, mas que em uma cidade planejada, poderia ter sido evita do. Nas três quadras centra is, as calçadas a presentam de 3 a 6 metros de largura, porém não se convertem em espaços com qualidade. Nos levantamentos realizados a rua aparece como a principal via de circulação de pedestres. 

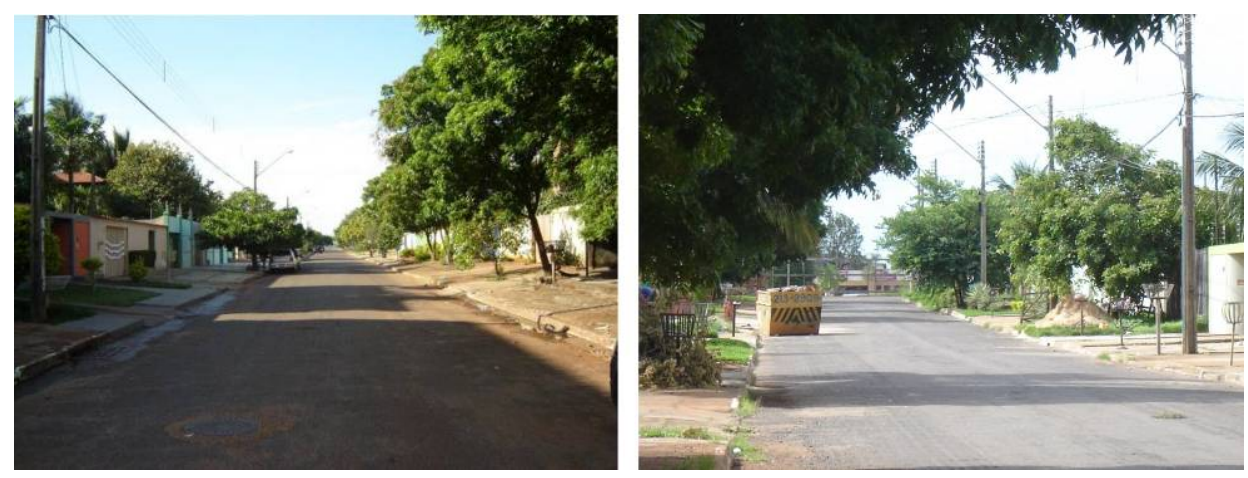

Fig. 115, Calçadas que não promovem urbanidade, apesarda generosidade de suas dimensões. (Fonte: a utor, 2006)

O espaço público é ainda uma grande questão no projeto urbano. Se ele em si é uma questão, como idealizá-lo? Como fazer com que a vitalidade urbana seja algo promovida pela esfera pública da vida cotidiana? Talvez a solução não esteja propriamente no projeto, mas nos seus limites, nas bordas, nas interfaces que se revelam da relação entre o espaço livre e o construído.

Mesmo com a redução do potencial de uso das áreas públicas na região central, elas ocorrem e se revelam nos a contecimentos do cotidiano. Alguns fatores caracterizam parte desta vida coletiva presente nas praças, ruas e áreas comerciais, caracterizada principalmente pelos ritos de uma nova sociedade que se adapta ao espaço determinado e inscrevendo suas marcas.

As barreiras físicas são a mpliadas com a fragmentação social que se conformou no processo de ocupação da cidade. A Arse21(Fig. 116), a quadra com maior renda por habitante de Palmas (SEDUH, 2006), é a única que apresenta um tratamento paisagístico diferenciado nos limites e acessos à quadra. Fisicamente, o projeto da quadra não impede qualquer morador da cidade de passar por suas ruas, mas a inexistência de uma centralidade intema na quadra se reflete na baixa movimentação de pessoas que circulam por dentro da quadra, interferindo na axialidade e na potencialidade de seu espaço urbano. 

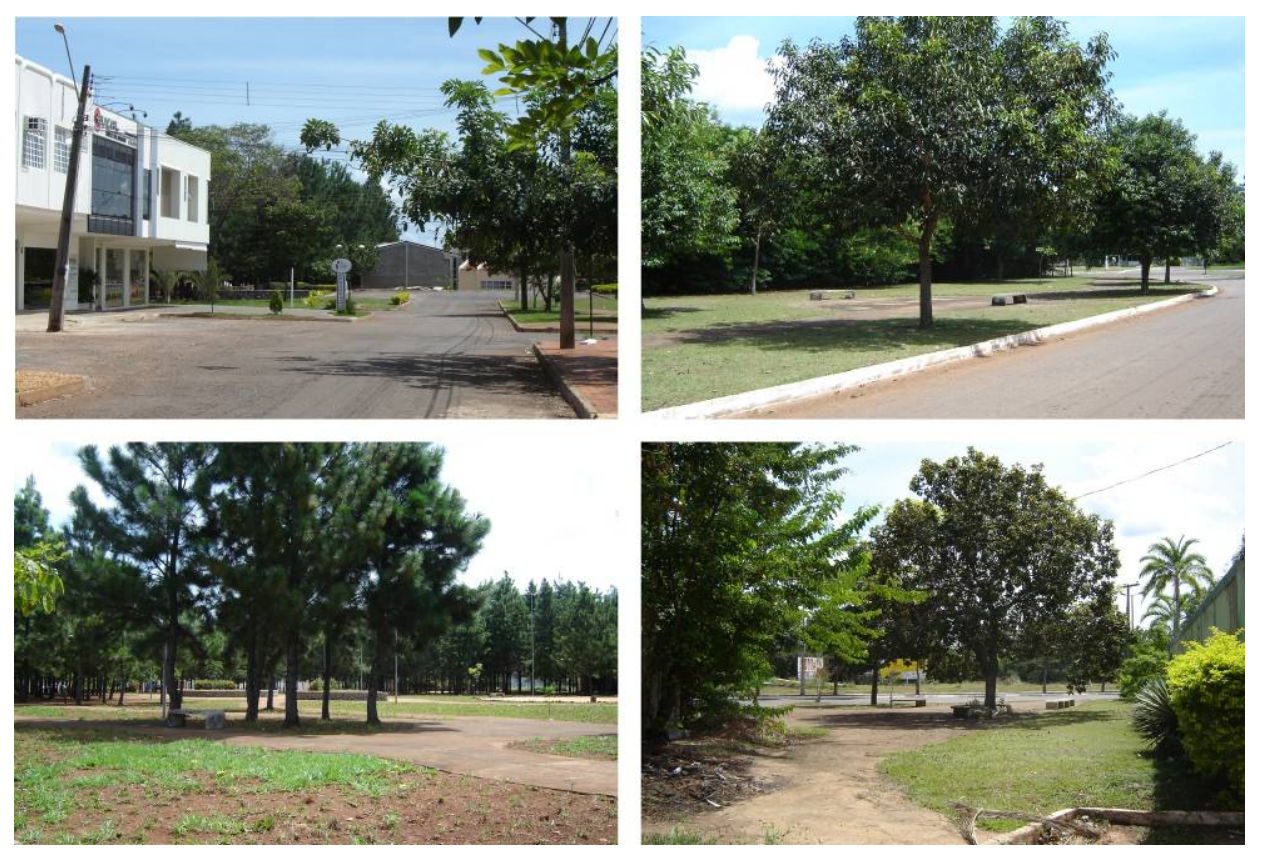

Fig. 116, Fotos da Arse21, a quadra que se diferencia por sua qualidade espacial. Nas fotos percebe-se o comérc io que se localiza no interior da quadra, o acesso viá rio da quadra, a

praça central e o acesso de pedestres que se localizam entre no fim de cul-de-sacs. A qualidade do tratamento não intensifica a apropriação. (Fonte: autor, 2007)

$\mathrm{Na}$ Vila União, existe atualmente a mesma delimitação de áreas públicas e privadas, condicionada pelo projeto urbano. A necessidade de conquista da esfera privada que a invasão proporcionou, modificou diretamente a condição de esfera pública do bairro: o privado determinou o público. A relação espacial entre o edificado e o livre a presenta uma outra conotação. As barreiras também existem, com muros nas frentes dos lotes, limitando as quadras e as avenidas, porém a conexão com o espaço livre se baseia no processo coletivo de apropriação, e por isso ele ganhou outro signific a do junto a essa população.

As áreas a propriadas pela população, não são praças ou canteiros bem cuidados, mas áreas públic as que derivaram do parcelamento urbano e agora fomam lugares. A esfera pública do espaço na Vila União advém justamente das potencialidades criadas pelas forças cultura is que 0 construíram. Isso gerou uma diversidade de lugares, que referenciam a identidade e a memória da construção do bairro.

$\mathrm{Na}$ Fig. 117, a diversidade do traçado marca a urbanística da Vila União, em um pastiche de formas e grande quantidade de espaços livres. 
No caso da Amo 31 e 33, o conceito de praça tradicional se manteve, porém conectadas ao novo contexto que se formou.

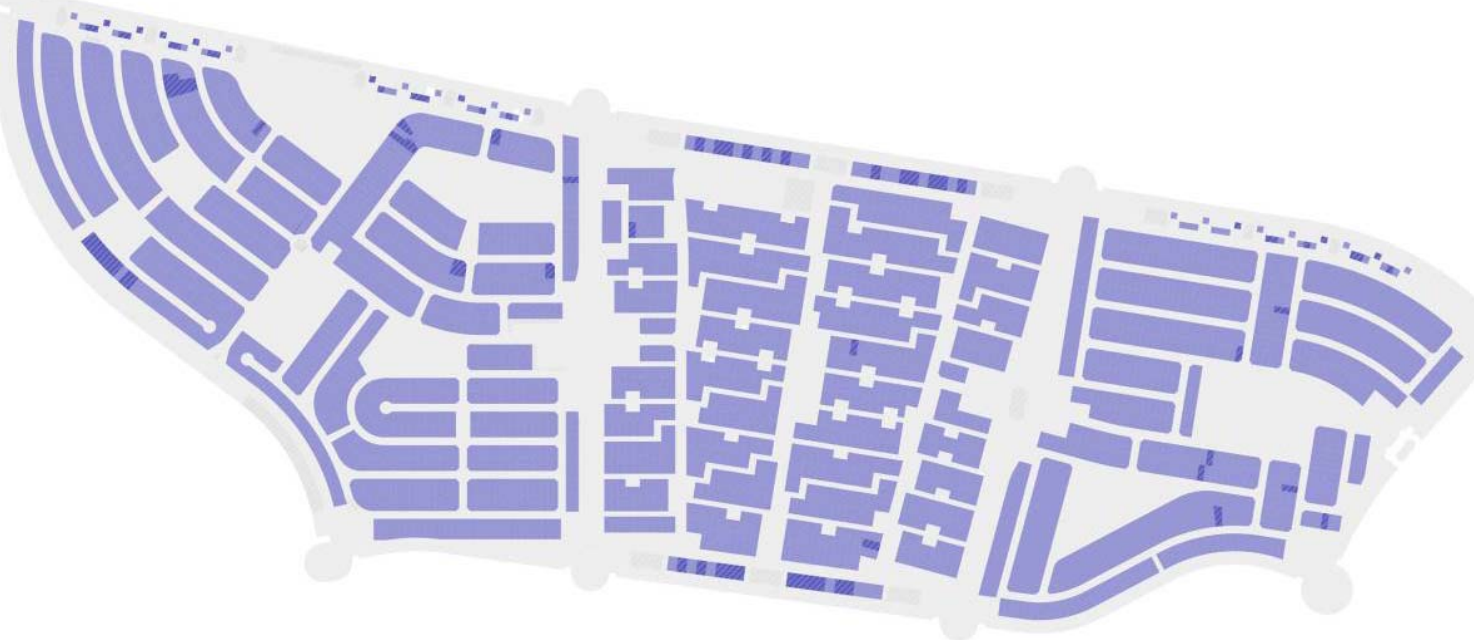

Fig. 117, Espaços priva dos e livres da Vila União. (Fonte: a utor, 2006)

O espaço privado mantém a sua importância no cotidiano dos moradores. A conquista do lote é o elo da história do bairro e de cada vida que se construiu através da obtenção do direito de moradia. Se esse representa a conquista da esfera privada, o espaço público representa a conquista de uma esfera comunitária, onde cada memória completa a ocupação do ba irro, inscrevendo as marcas de sua conformação.

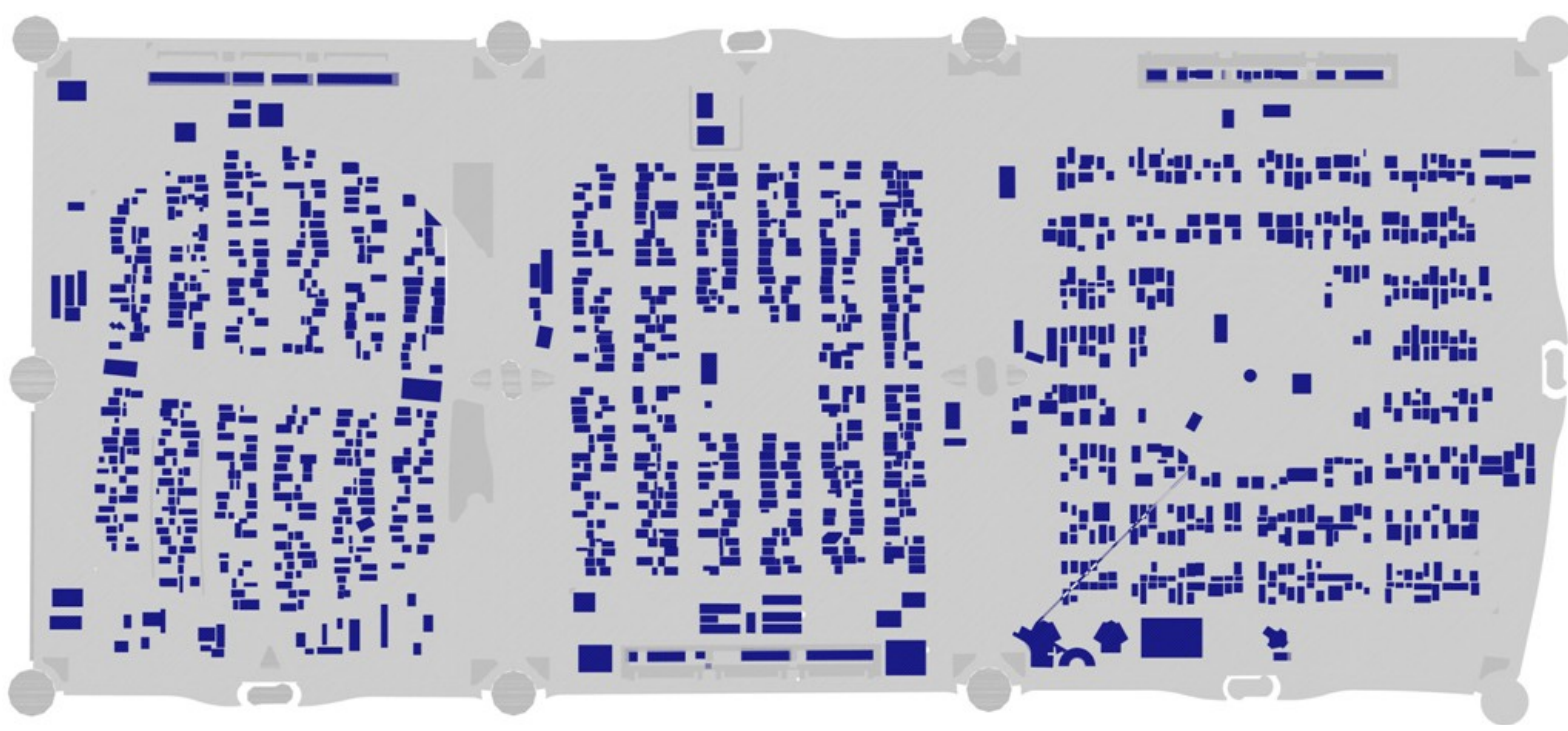

Fig. 118, Espaç os ed ific a dos e não edific a dos das qua dras centra is. (Fonte: a utor, 2006) 
Na Fig. 118, está marcada em azul a área edificada das três quadras da região central. Em cinza, as áreas livres de edificação, não necessariamente públicas. O seu destaque pode indicar uma boa qualidade urbana, porém não implica na conformação de lugares. O potencial de espaços não edificados não se completa com o sistema de espaços livres. $\mathrm{Na}$ área central, ainda existe metade dos terrenos multifamiliares a serem edificados, projetando uma taxa de densidade ainda maior. À medida que estes forem ocupados, uma nova dinâmica ocorrerá, porém se mantiver a mesma postura das construções atuais, a relação entre edificado e não tenderá a permanecera mesma.

A qualidade edilícia da Vila União não apresenta a mesma condição estética da região central, porém, algumas caractenísticas da história de ocupação ainda permanecem presentes. Algumas casas feitas pelo poder público para as famílias locais ainda marcam a paisagem, retratando essa conquista (Fig. 119). Muitas sofreram transformações: ampliações, novos acabamentos, e principalmente muros, porém, algumas apresentam sua característica original, principalmente sem muros na parte frontal e lateral, criando uma ambiência que potencializa a interação entre rua e lote.
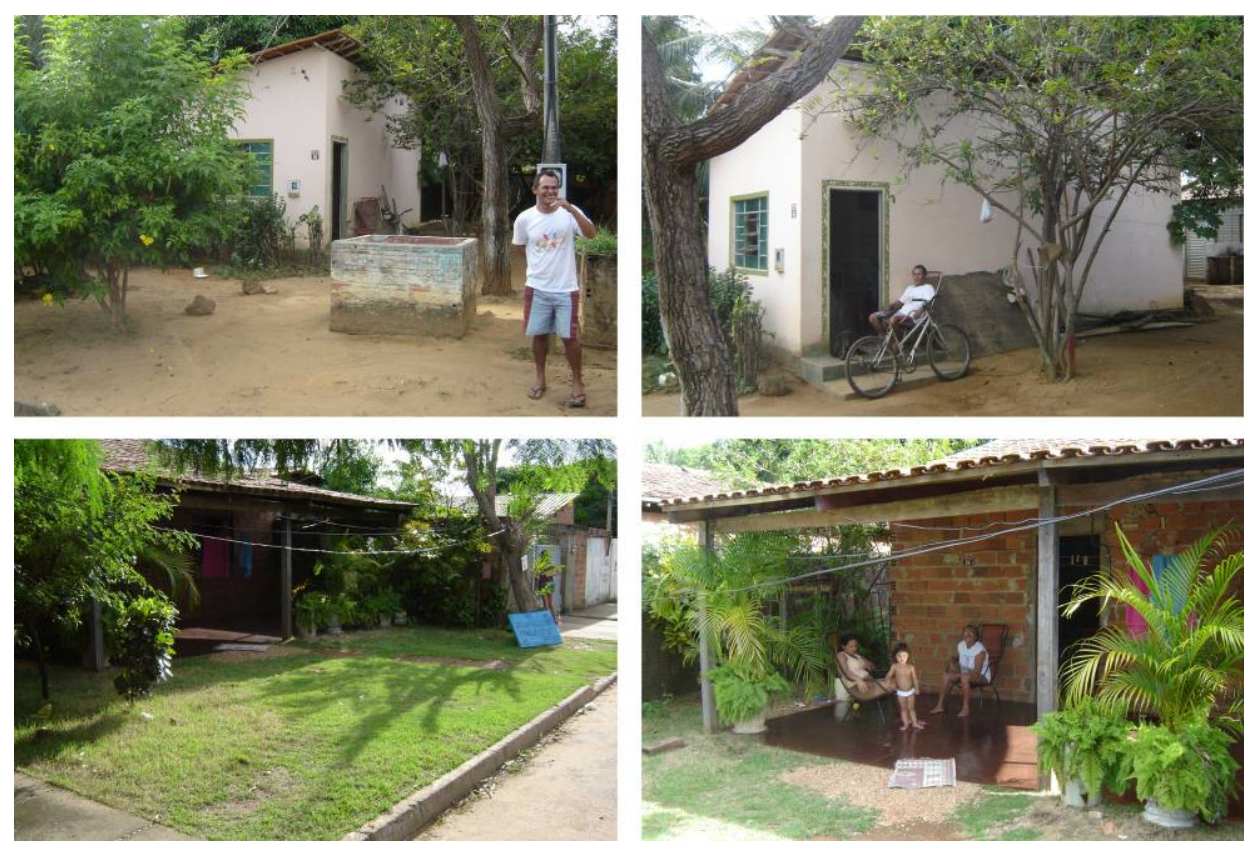

Fig. 119, Cenários do cotidiano da Vila União. Algumas edificações sem muro permitem uma interação de seus moradores com o a mbiente público. (Fonte: autor, 2007) 
A separação entre parcelamento urbano e tipologia edilícia interferiu diretamente na interação entre arquitetura e espaço urbano. O problema não está diretamente na parcela, mas na convicção de que a arquitetura é algo independente. A arquitetura é para a cidade, para o cidadão, para o pedestre e para o carro, para o proprietário e expectador. Não é uma defesa da privacidade, mas da interação entre espaços livres e arquiteturas geradas pelo privado. Em Palmas, os limites de público e privado deveriam ser de alguma forma uma arquitetura que possibilitasse uma maior interlocução entre essas duas esferas, porém a divisão é feita pelos muros, cada vez mais presentese consolidados na paisagem.

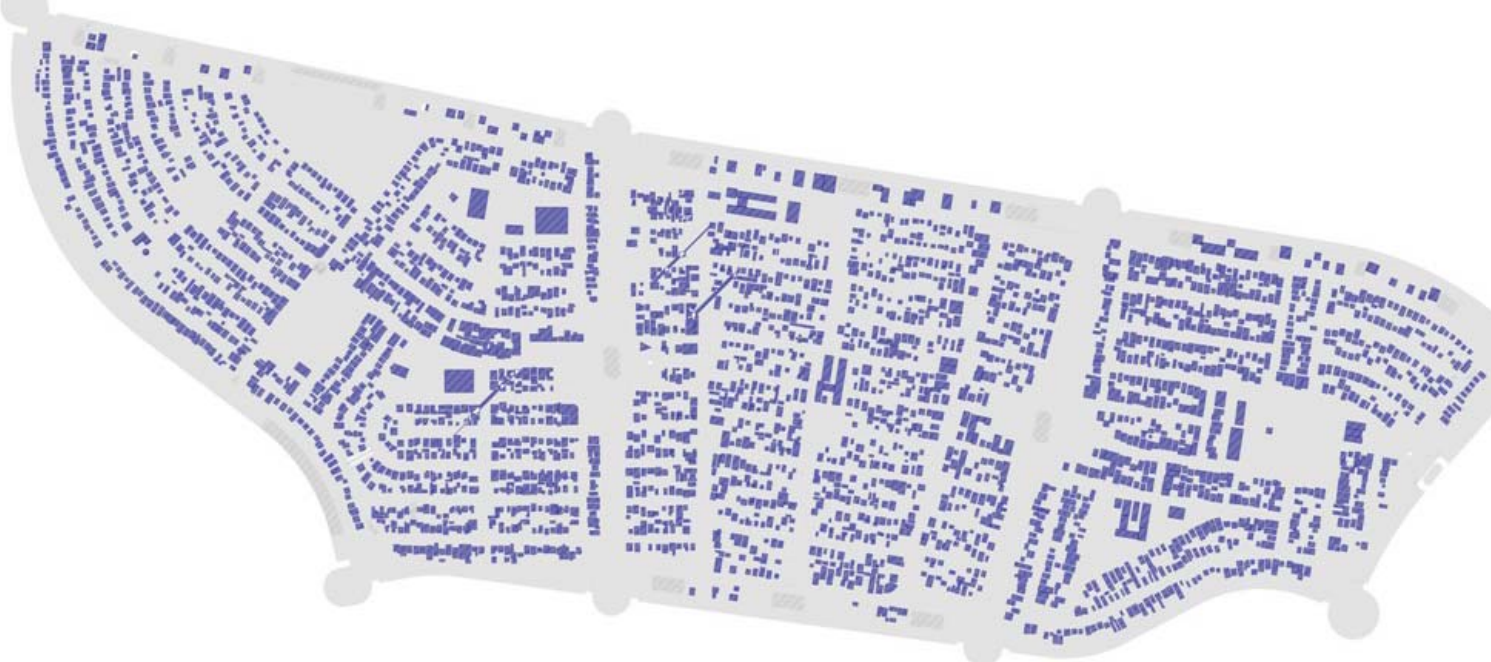

Fig. 120, Áreas edific a dase não edifica das da Vila União. (Fonte: a utor, 2006)
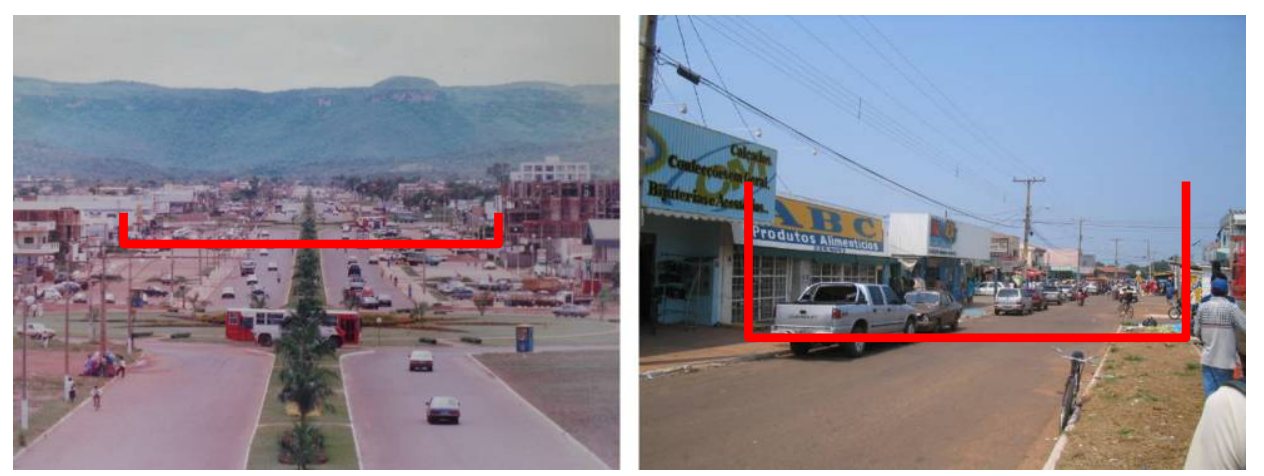

Fig. 121, Relação entre a escala da arquitetura e do espaço livre. Área comercial vic inal na região central e comérc io da Vila União. (Fonte: Autor, 2006) 
A a rquitetura não é o limite do espaço livre, é onde ela se completa. A urbanidade depende da riqueza dessa ambigüidade, da dialética entre público e privado, da separação que determina a dimensão individual e coletiva de cada indivíduo no espaço. O modemismo categorizou o espaço livre como um condicionante essencial para a boa arquitetura, porém sem condicioná-lo aos limites necessánios para uma escala gregária. Esta depende das diferentes esferas de relação com o construído. Embora Brasília apresente na macro-escala esse distanciamento, nas superquadras a enome quantidade de áreas livres se conecta com as edificações, criando uma interdependência entre essas duas categorias do urbano.
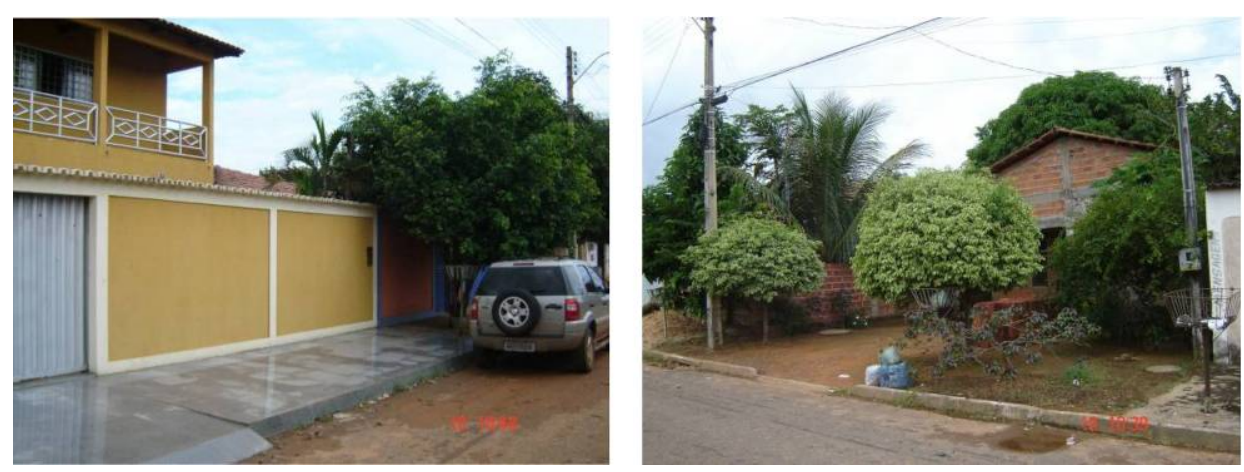

Fig. 122, Transformação e manutenção das características edilícias: Vila União. (Fonte: a utor, 2006)

Mesmo se o projeto de Palmas tivesse uma tipologia edilícia para as habitações, talvez a Vila União destoasse a inda ma is do plano, assim como a Vila Planalto ${ }^{31}$ destoa do Plano Piloto em Brasília. As quadras apresentam algumas caracteństic as derivadas dos programas de habitação social e da autoconstrução. Na Vila União, essa relação começa a seguir a mesma caracteriza ção das quadras centra is, com o crescimento de residências que fecham seus lotes com muros, impossibilitando uma maior interação. As transformações no espaço e no tempo possibilitarão novas interfaces ou novas ruptura s entre essas dimensões.

31 Acampamento de empreiteiras que se conformou como um bairo tradicional dentro do plano Piloto de Braślia, próximo ao Palácio do Planalto, destoando da paisagem ordenada da cidade. 


\section{Interface}

As interfaces remetem à idéia de troca, de contato, de interação, e principalmente de limites e potencialidades entre os elementos que constituem a paisagem, as tramas urbanas e sociais de uma cidade. As críticas à segregação propiciada pela privação da coletividade pública em ambientes privados, murados e não conectados com o ambiente urbano, abastece a discussão de como o projeto urbano pode, e deve, condicionar o seu traçado, parcelamento, tipologia edilícia e implantação, para uma cidade com interfaces.

Essas ocorrem no cotidiano de uma cidade, e dependem em parte das dinâmicas socia is e cultura is que se apropriam do seu espaço, e em parte de como o projeto urbano, a arquitetura, e os espaços livres estão conectados, conferindo as trocas necessáriaspara a urbanidade.

Caldeira alerta para o perigo da exclusão proporcionada pelos condomínios que se alastram pelas cidades brasileiras, causando uma segregação espacial e social preocupante para o planejamento urbano. Por mais que estes lugares façam parte da malha urbana, e criem uma imagem de "qualidade", não ocorre uma interação com o restante dos elementos que constituem as outras partes da cidade, fragmentando o espaço em núcleos que não se conectam. Assim como afima Pesci (1999), a idéia modema de interfaces é muito mais rica e complexa que a histórica: mais que um limite, ela é o ponto máximo de interação.

\footnotetext{
“Na verdade, espaço urbano e sociedade são duas faces da mesma moeda; ou seja, o espaço é um aspecto estrutural da cidade. Seu papel supera o conceito sociológico de suporte de atividades, pois não é um meio rígido e neutro, mas capaz de oferecer possibilidades e restrições á realização de práticas. Sua natureza social implica que o espaço da cidade seja necessariamente histórico, no sentido de posicionado em marcos tempora is, geográficose cultura is." (KOLHSDORF, 1996, p 21)
}

A urbe é um fato físico promotor desta interação. Pesci enfatiza duas categorias de interfaces, Ativa e Passiva, ou Social e Física, para caracterizar 
as intera ções existentes em uma cidade, seja pela sua função infoma cional, seu papel urbano e seu valor comunicacional. Entendendo como Kolhsdorf, que espaço urbano e sociedade são dois lados da mesma moeda, duas va riá veis físic a s foram identific a das para esta a nálise - interfaces e ba rreiras utilizando subcategorias para uma melhor sistematização dos dados: entre espaço construído e espaço livre; entre atividades (distintas); entre espaços livres; e entre espaços construídos.

Um caminho para a urbanidade é alimentar os espaços livres de entradas, contrapondo espaços cegos, mortos, residuais de uma cidade. As ba rreiras físic as urbanas dific ultam as intera ções soc ia is. Se um dos conceitos principais da unidade de vizinhança de Palmas era promover essa diversidade, entre pessoas de diferentes heranças cultura is e classes socia is, as barreiras criadas e originadas pelo projeto urbano promovem 0 cisalha mento dessa s forças a tra vés do espaço.

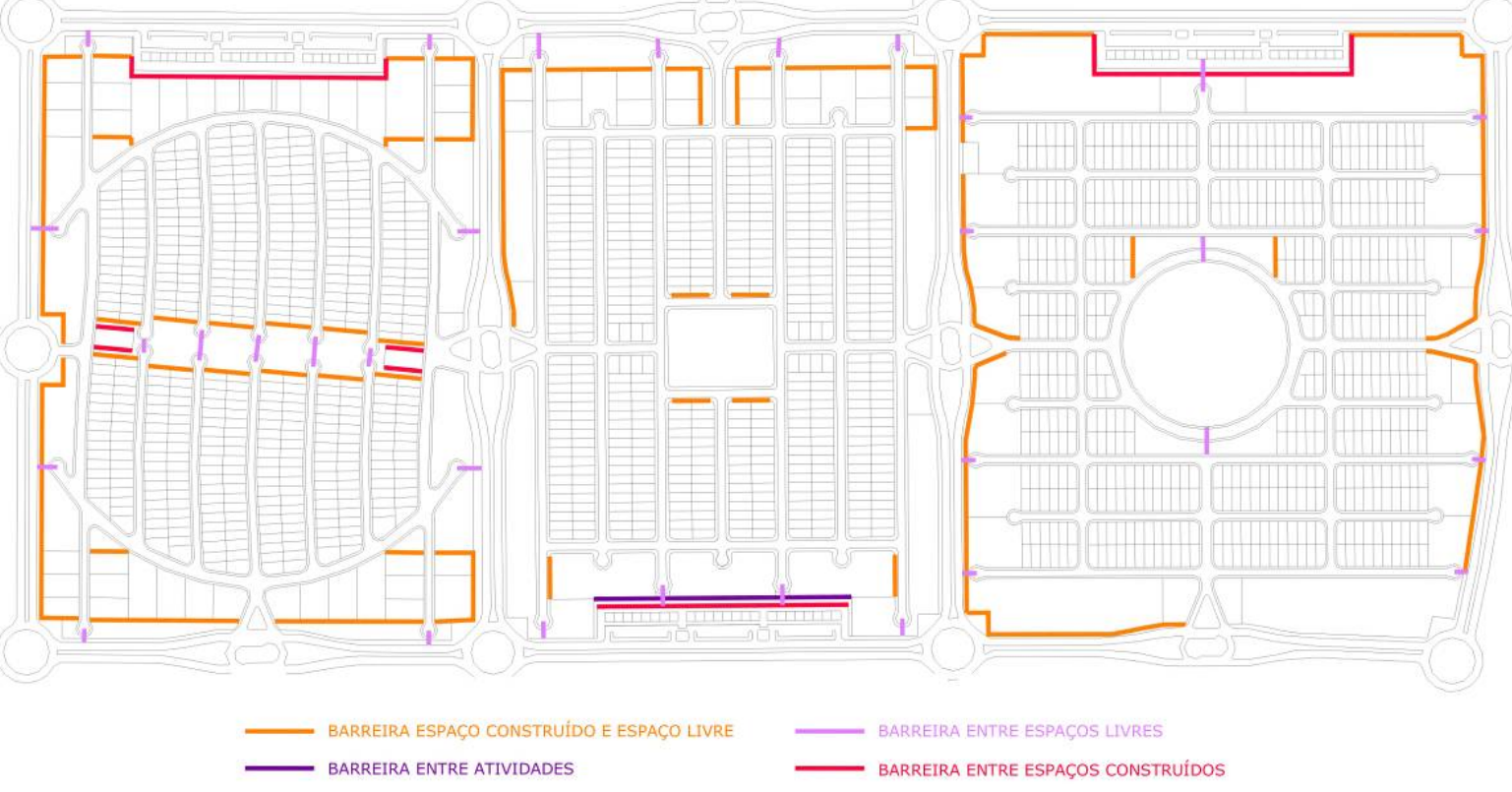

Fig. 123, Barreira s existentes na região central. (Fonte: a utor, 2006)

A Fig. 123 apresenta as barreiras da região central, caracterizadas pelas subcategorias de a nálise. A que ocorre em maior intensidade é entre o espaço construído e livre, na cor laranja. Esta se dá principalmente pelo parcelamento que se configura voltado para o interior da quadra, 
fragmentando-a. Os muros dos lotes residenciais, bloqueiam as bordas das quadras, transformando os espaços livres junto às avenidas em loca is sem nenhuma conexão e interação com o traçado urbano.
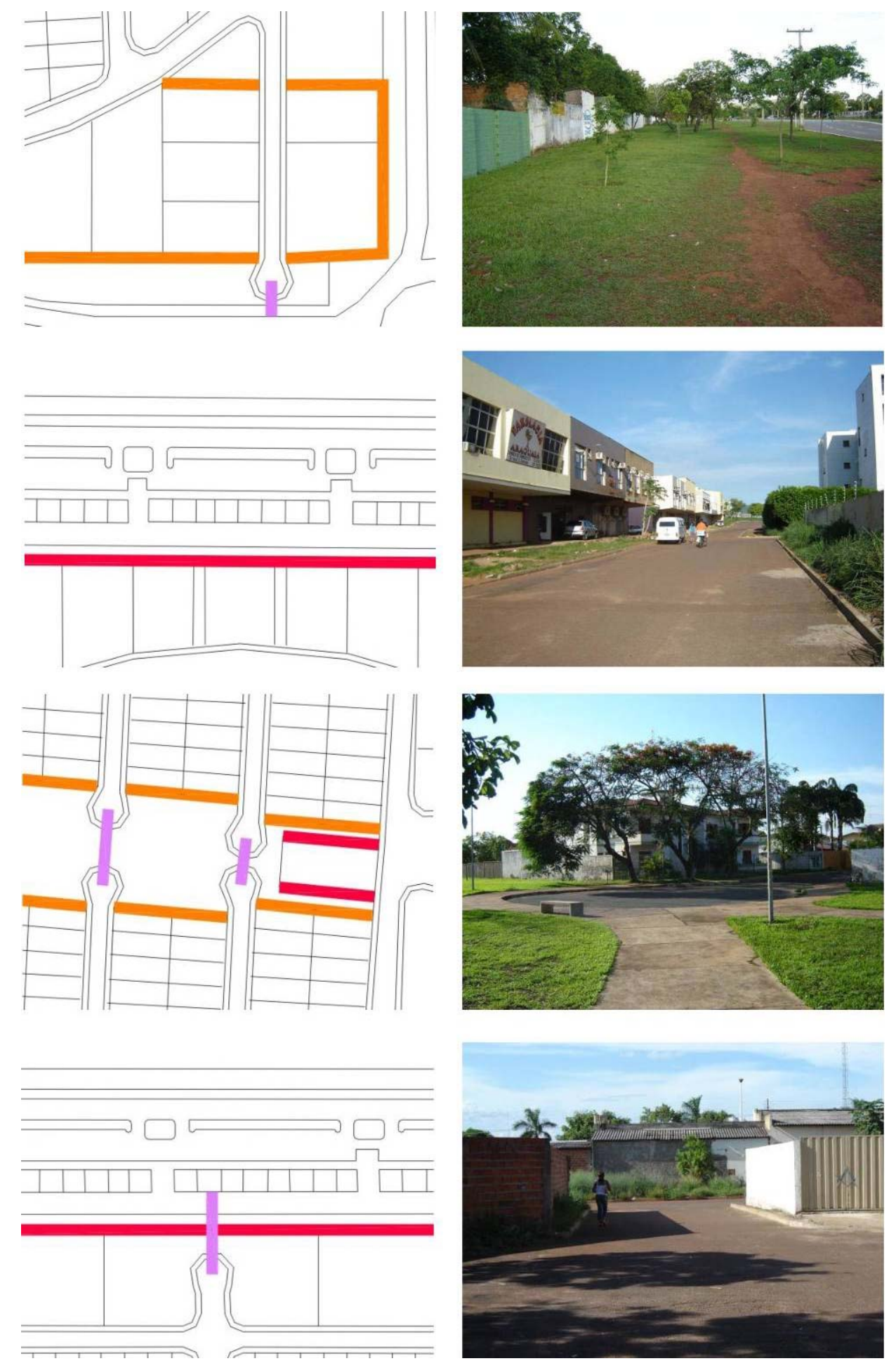

Fig. 124, Ba rreiras no espaço das quadras centra is. A potenc ialida de espacial é perdida por ba rreiras que limitam a interação. Na última foto, caminho criado em um lote privado para facilitar o fluxo de pessoas pela quadra. (Fonte: autor, 2006) 
Em vermelho estão demarcadas as barreiras entre os espaços construídos. Nos principais pontos de atratividade das quadras, a falta de integração do comércio com as residências, formou uma lacuna, um espaço subutilizado que se conforma como um vazio. Na Arse 13, o comércio vicinal está junto a uma universidade, porém, não há nenhuma interface entre esses dois importantes elementos urbanos, impedindo atividades que poderiam formar uma área com intensa vitalidade.

O sistema viário fechado adotado para as quadras centrais, bloqueou a ligação entre os espaços livres. Muitas foram rompidas, demonstrando a força cultural que se inscreve nos espaços da cidade. Estas não devem ser traduzidas apenas como algo negativo para o projeto urbano, pois a sua contraposição, transgressão e conflito, geram potencialidades de conformação de lugaresem meio a detemina dos contextos urbanos.

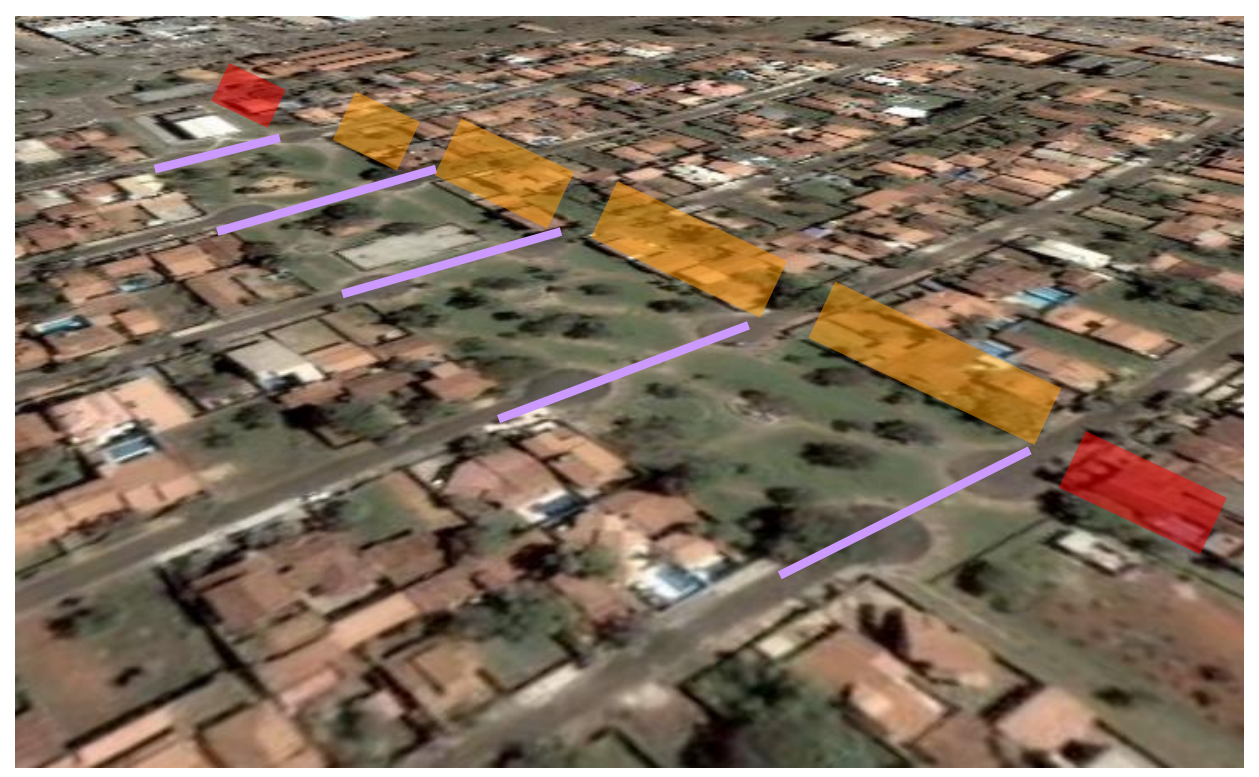

Fig. 125, Foto aérea da praça central da Arse12. Na corlaranja as barreiras entre espaço construíd o e livre; na cor lilás as barreira s entre espaços livres; na cor la ranja as barreiras entre espaç os construídos. (Fonte: GOOG LE EARTH, 2007)

A praça da Arse12 (Fig. 125) contém três categorias de barreiras: os muros latera is dos lotes residencia is forma $m$ fachadas cegas para a praça entre espaço construído e livre; os muros laterais das residências não permitem uma integração com as igrejas - entre espaços construídos; e os cul-de-sacs do traçado urbano impedem uma maior circulação pela 
quadra - entre espaços livres. Essa praça, que deveria promover uma integração espacial é desvalorizada por essas barreiras.

As interfaces, por outro lado, propiciam a criação de lugares. Nas quadras centrais elas ocorrem principalmente entre algumas áreas livres e espaços construídos, onde o seu interior e suas bordas se conectam com as avenidas arteriais. Este modelo de projeto foi pouco utiliza do na cidade, prevalecendo barreiras físicas, como os muros residenciais. Isso permitiria uma maior integração entre os espaços urbanos e aumento dos fluxos, permanências e principalmente na conformação de uma nova paisagem urbana.

A Fig. 126 apresenta as interfaces que se caracterizam nas quadras centrais. Elas ocorrem com maior intensidade na Arse13, principalmente entre espaços livres, linhas na cor verde escuro, potencialmente condicionadas a minimizar o impacto causado pelas barreiras. As linhas na cor verde claro, representam as diferentes atividades. Esta é uma forma de caracterizar a quantidade de áreas com usos diversificados que interagem espacialmente. Em alguns pontos no interior e na borda das quadras, há integração entre áreas livres, comércio e instituições, que se configuram como pontos de atratividade.

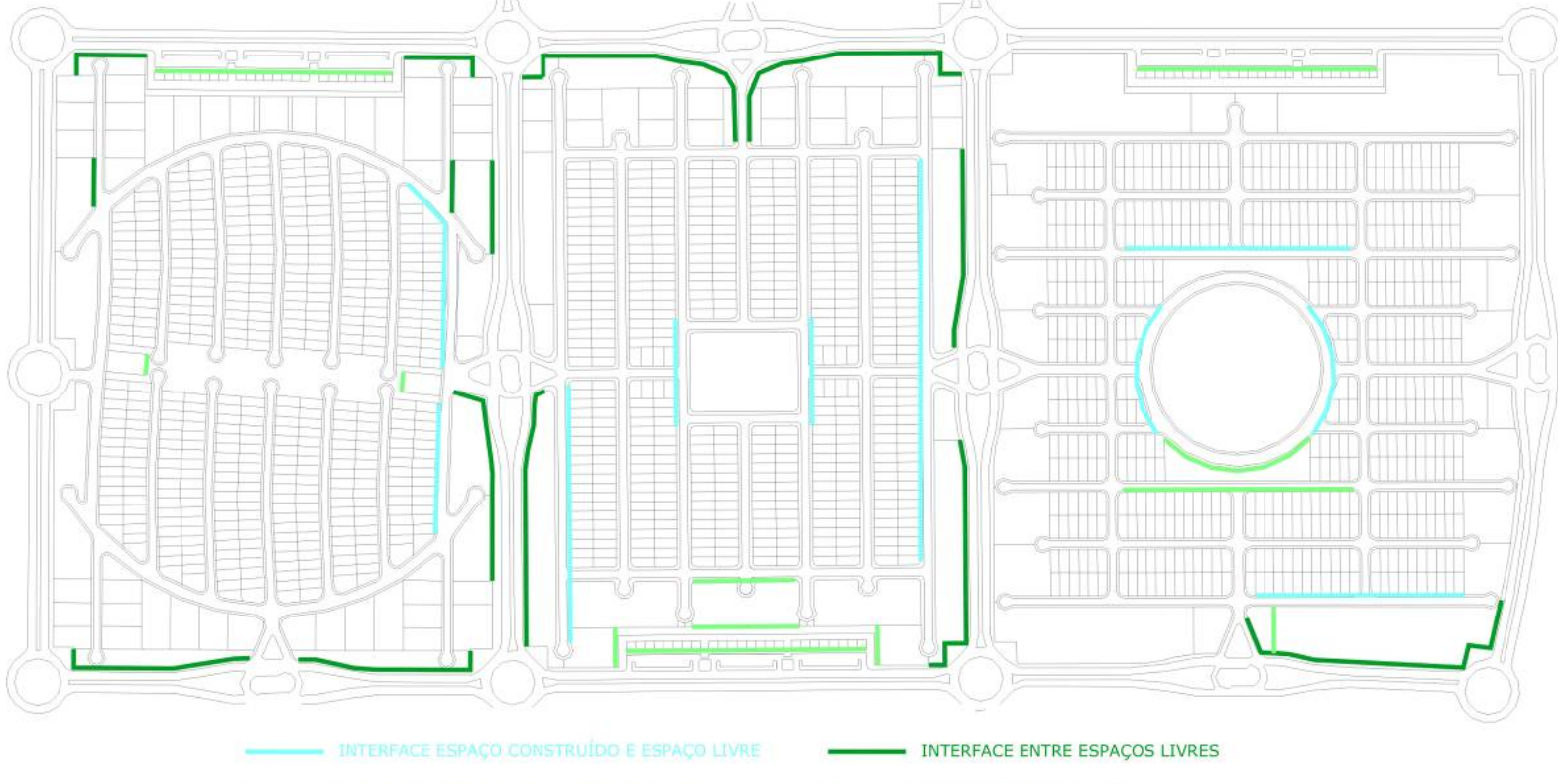

Fig. 126, Interfac es existentes nas qua dra s centra is. (Fonte: a utor, 2006) 

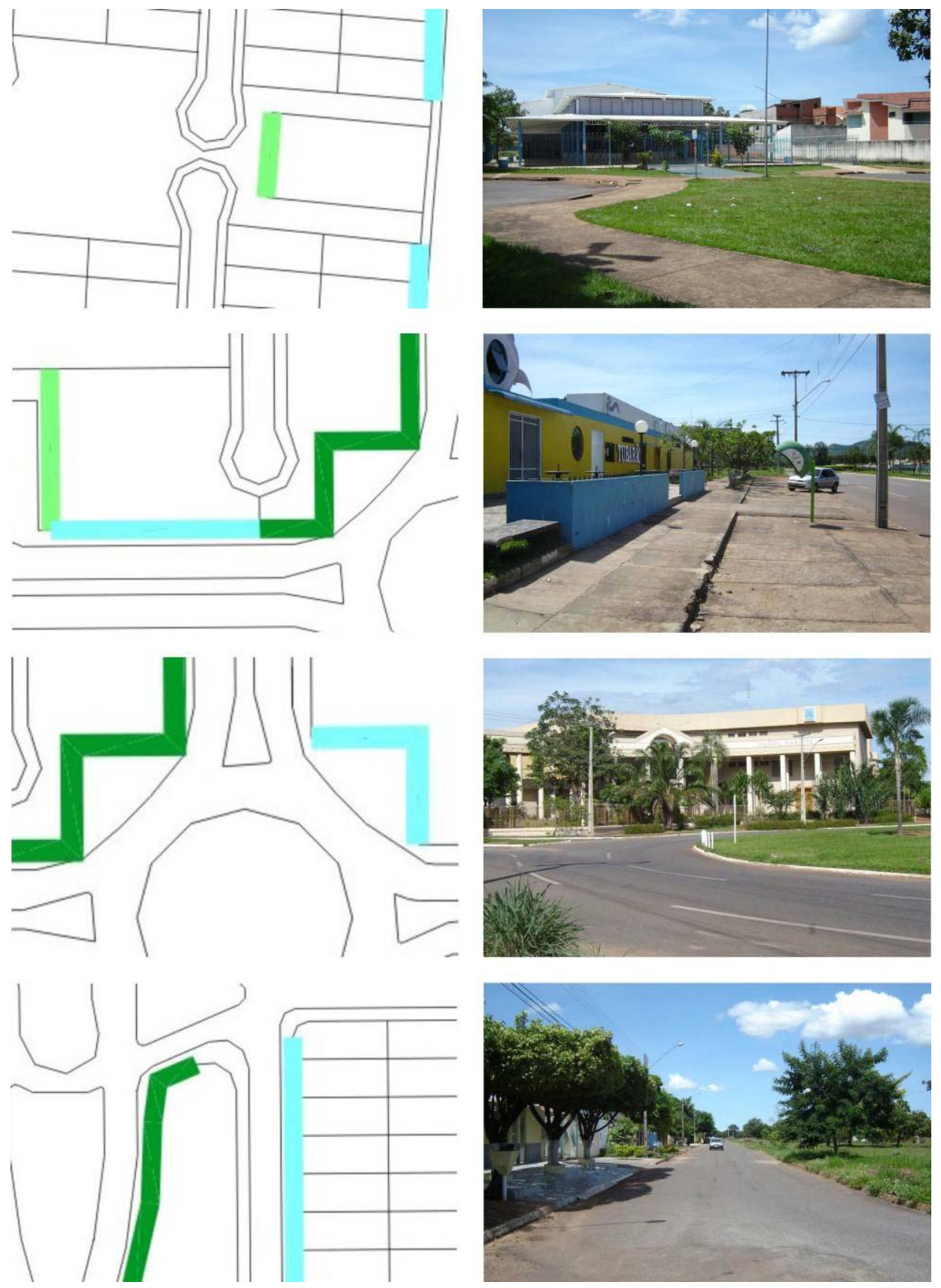

Fig. 127, Interfac es que ocorrem nas quadras centra is. A primeira foto representa a igreja

que se abre para a praça, permitindo uma interface com o espaço livre. A segunda apresenta o comércio junto à avenida que se conecta diretamente com ela. A terceira foto é a fachada que se volta para a rotatória, fato raro na cidade. A última representa uma rua na borda da quadra que se conecta com um espaço verde. (Fonte: autor, 2006)

Na Fig. 127, em azul claro, está destacada a interface entre o espaço construído e o espaço livre. Esta apresenta um fator deteminante para a conformação de urbanidade. Este remete a qualidade ambiental local, onde fatores témicos e paisagísticos auxiliam na ambiência urbana, 
promovendo uma paisagem capaz de amenizar os efeitos causados pela destruição da vegetação local.

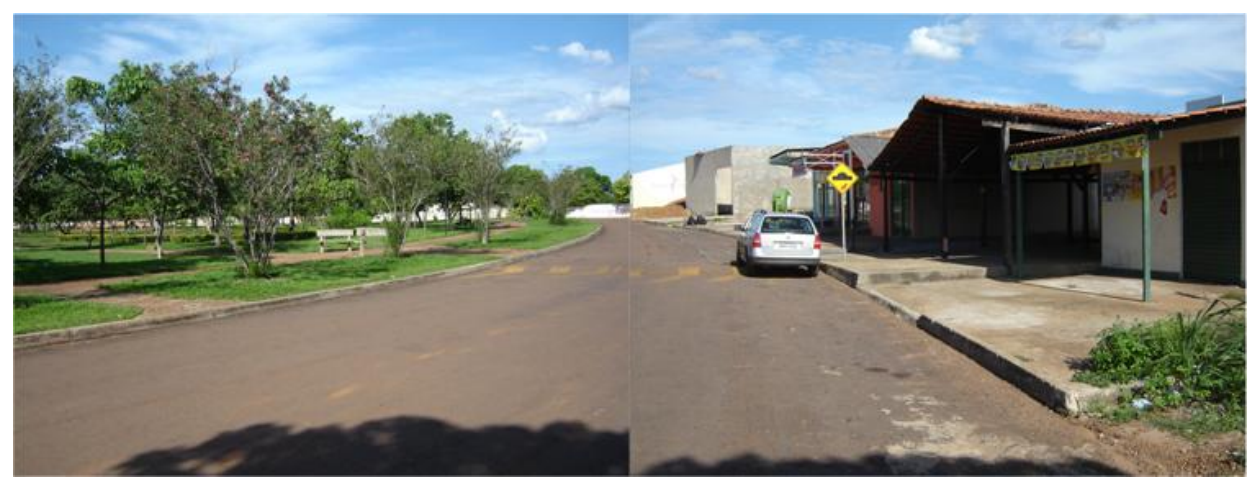

Fig. 128, Interface na Arse 14. O comérc io localiza do a direita se localiza em uma área destinada à área verde. (Fonte: autor, 2006)

A contraposição aos modos tradicionais de ocupação das unidades de vizinhança na Vila União, fez com que as interfaces formassem a gênese desta ocupação: limites entre o poder público e a sociedade civil, entre o espaço natural e o antrópico, e principalmente entre diferentes grupos sociais. Se o projeto idealizado para as quadras propôs os mesmos parâmetros urbanísticos das demais da cidade, a transfomação dos espaços foi criando novos lugares em meio à ordenação imposta pelo traçado. As interfaces iniciais estão presentes até a atualidade, histórias inscritas na paisagem e no contexto urbano.

Embora as interfaces ressa Item os limites do projeto na Vila União, este também produziu barreiras, interferindo na potencialidade de ampliação das interações socia is e espacia is. As principais se caracterizam novamente entre o espaço construído e o espaço livre. Algumas bordas das quadras caracterizam-se por uma paisagem de muros que se volta para o espaço das avenidas, mesmo onde há acessos e conexões diretas para esses. Isto ocorre principalmente nos lotes vizinhos a áreas de preservação, na parte inferior da Fig. 129, na cor laranja. 


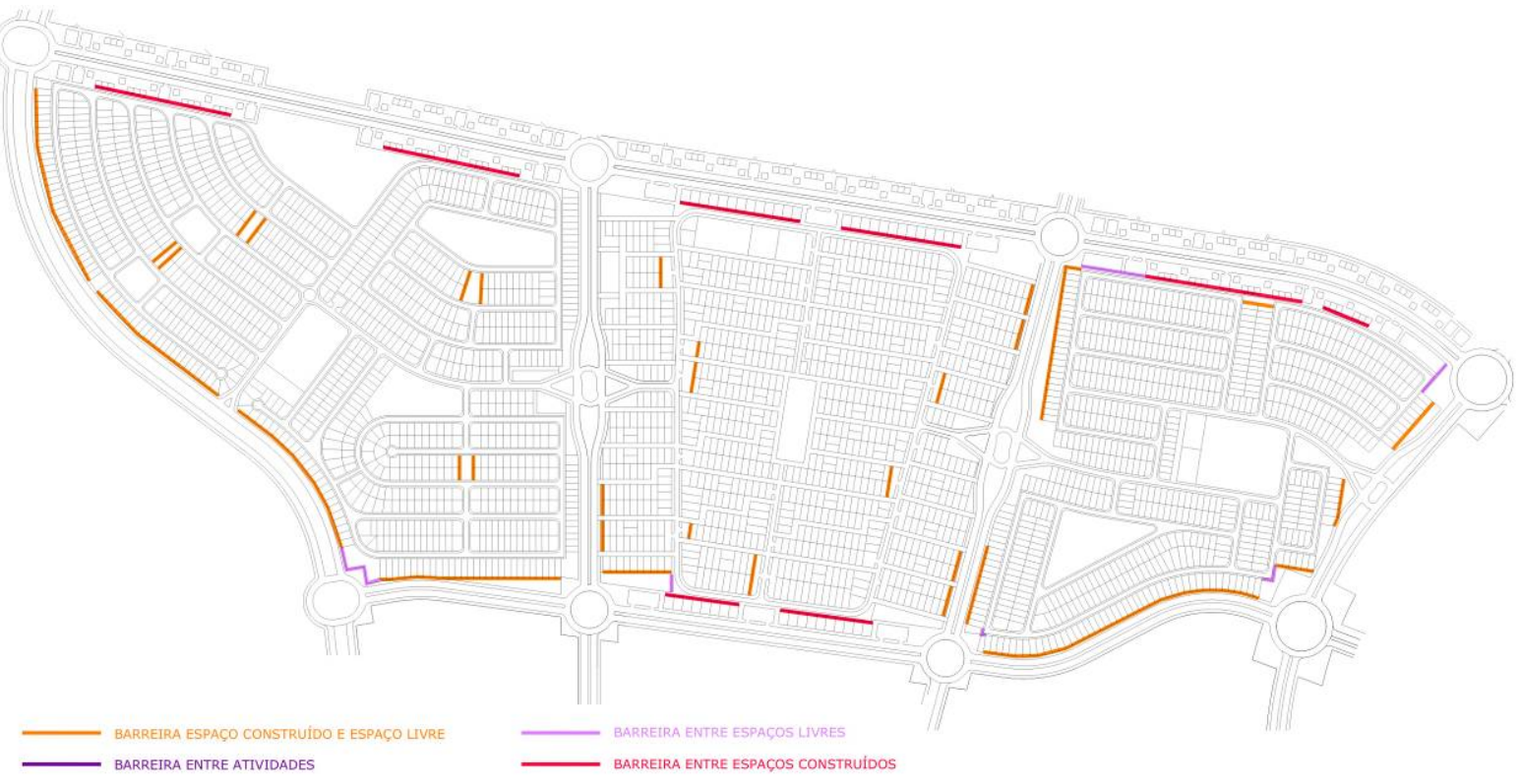

Fig. 129, Barreiras na Vila Uniã o. (Fonte: autor, 2006)
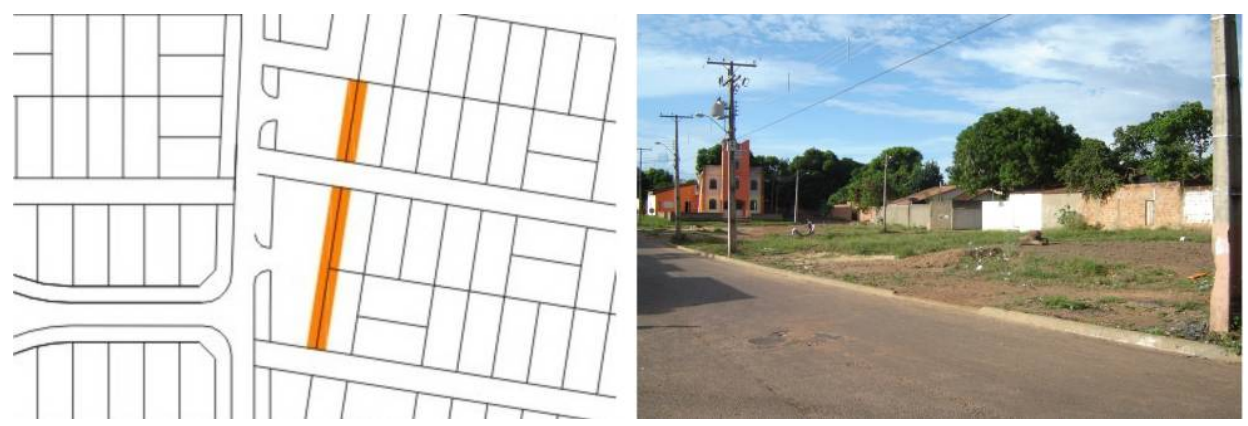

Fig. 130, Barreiras na Vila União. Na primeira foto os muros de residências junto a áreas livres, formando espaçoscegos. Na segunda, o comérc io que a inda não se constituiu, por não a presentar interface de atividades com o restante da quadra. (Fonte: autor, 2006)

Outras barreiras se dão através dos muros latera is dos lotes que estão junto a espaços livres. Nas Amo 32 e 33, algumas dessas áreas não se conectaram com o espaço construído, fomando barreiras ao longo do traçado e impossibilitando um uso efetivo destas áreas.

O comércio vicinal na Vila União, como já fora demonstrado, não se constitui como uma centralidade e um pólo de atratividade da população, formando uma barreira não só física para o acesso a quadra. Este se origina entre os espaços construídos, entre os fundos dos edifíc ios que não se voltam para o interior da quadra, configurando uma paisagem desconectada e que não se potencializa como lugar. 
As interfaces, em contrapartida, produzem uma outra caracteństica para sua paisagem. Se por um lado as áreas comerciais projetadas para esse fim se constituem como barreiras, as formadas pela contraposição ao uso especificado se constituem pela interação entre a sociedade e o espaço urbano. As novas centralidades criaram no mesmo espaço diferentes categorias destas. A Fig. 131 as representa na Vila União, se formando principalmente no novo eixo urba no que liga a praça da Amo31 à praça da Amo 33, passando pelo interior da Amo 32.

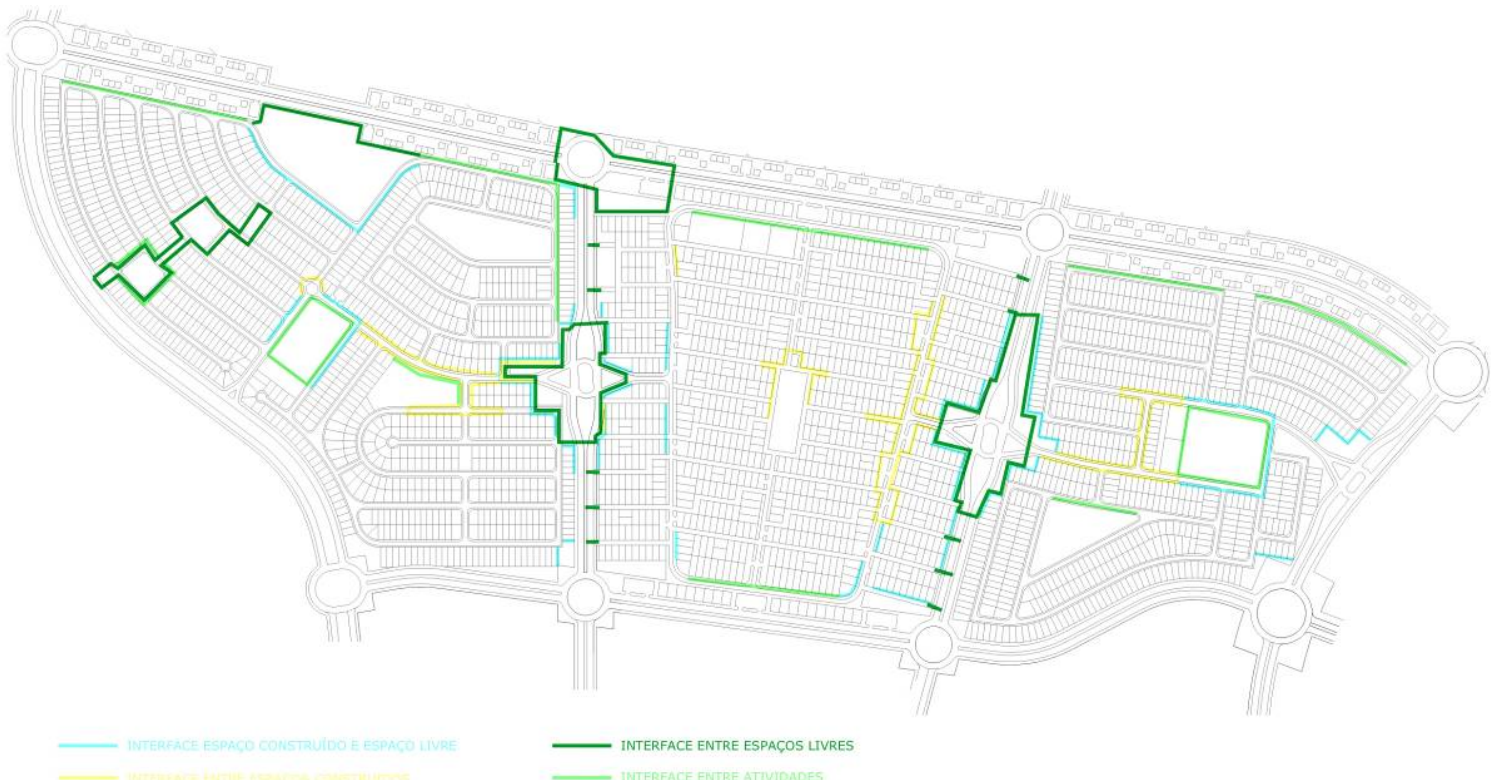

Fig. 131, Interfaces na Vila Uniã o. (Fonte: autor, 2006)

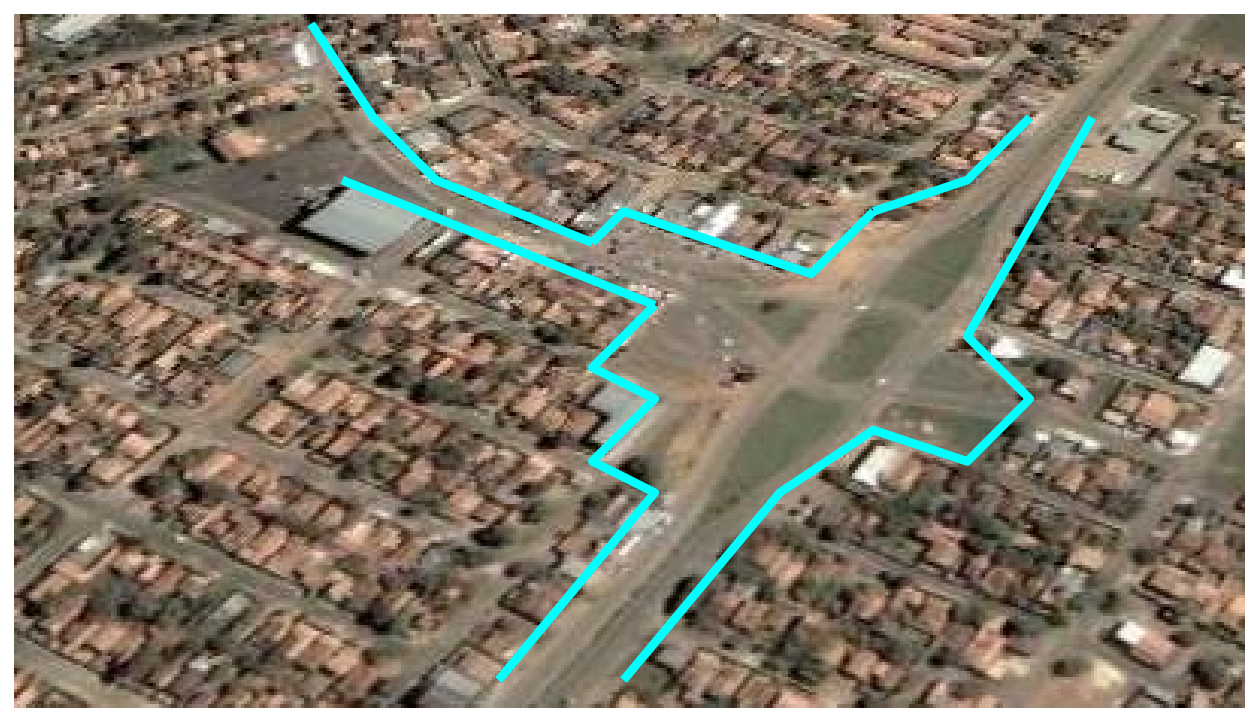

Fig. 132, Foto aérea da entrada das Quadras Amo32 e 33. Interfaces promovidas pela contraposição ao projeto. (Fonte: GOOGLE EARTH, 2007) 
A Fig. 132 representa uma foto aérea da entrada que divide as Amo 32 e 33. Neste ponto, o espaço que se configurou pela mudança de uso, pela abertura de ruas que chegam na avenida, e pela escala entre construído e livre, permite uma nova condição espacial.

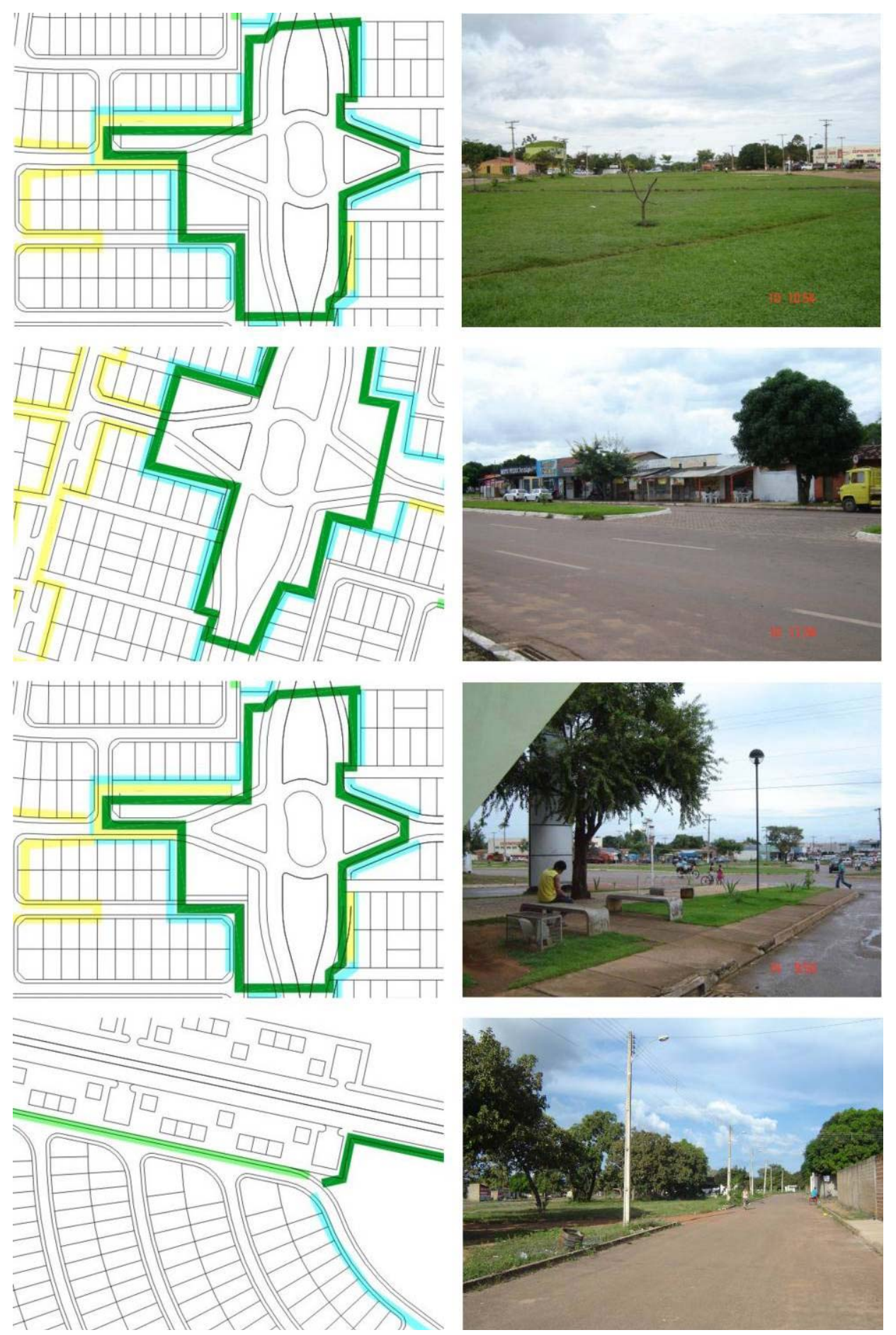

Fig. 133, A primeira foto refere-se à interface do canteiro central da Av. NS - 05. A mesma conforma ção ocorre na segunda foto, com um desvio aberto para facilitara capilaridade. A terceira representa uma pequena praça, que se conecta com o centro comercial. Na última, área residencial junto à área verde. (Fonte: a utor, 2006) 
As inúmeras rotatórias de Palmas não se constituem como lugar, principalmente pela a usência de conexões a o seu redor. Porém, as rotatórias da Amo 32 e 33 são exceções, devido aos pontos de atratividades que as cercam. Outro aspecto já destacado são as ligações entre as ruas locais da Amo 32 com as avenidas arteria is, criando novas interfaces entre a unidade de vizinhança e o plano, destacado em verde escuro na Fig. 133.

Uma conseqüência direta da transformação dos usos está na constituição do limite entre esfera urbana e social, constituído pela conjuntura cultural. O urbanismo com interfaces potencializa as interações físicas e sociais no espaço, promovendo diferentes graus de urbanidade, apoiada em uma esfera pública que se conforma através de lugares.

\section{Espaço V e rde}

A cidade de Palmas apresenta uma importante relação com os espaços verdes, categoria esta que abriga uma extensa área do parcelamento da cidade e que é responsável por parte da imagem de qualidade urbana proposta pelo plano e pelos gestores urbanos.

Os espaços verdes foram previstos como um sistema de áreas com hierarquias determinadas pela trama urbana e pela condição geográfica. A forma de apropriação, a relação com o contexto regional e a qualidade estética de cada parcela de espaço verde determina o grau de urbanidade dos lugares em Palmas. A transformação da paisagem reflete os conflitos culturais, econômicos e sociais que se revelam através da construção do espaço.

A geografia natural foi substituída por uma nova, delimitada por avenidas e canteiros arborizados, e que hoje representam parte de sua imagem paisagística. Esta, implantada nas avenidas arteriais, evidencia o limite entre a forte presença linear e espacial do plano e os espaços livres localizados nas suas bordas. Enquanto alguns são fragmentánios, outros se conectam criando uma complexidade de ambientes que são apropriados 
de diferentes modos pela população, fomando não só um sistema físico, mas de estruturas invisíveis e de relações socia is.
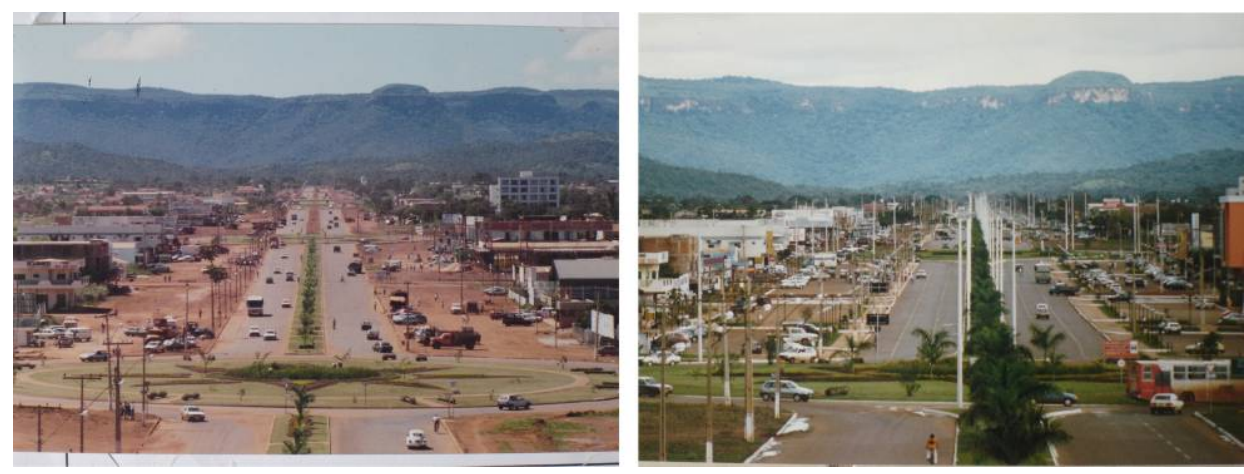

Fig. 134, Diferentes momentos do paisagismo dos canteiros e rotatórias da Avenida J K. (Fonte: SEMUC, 2006)
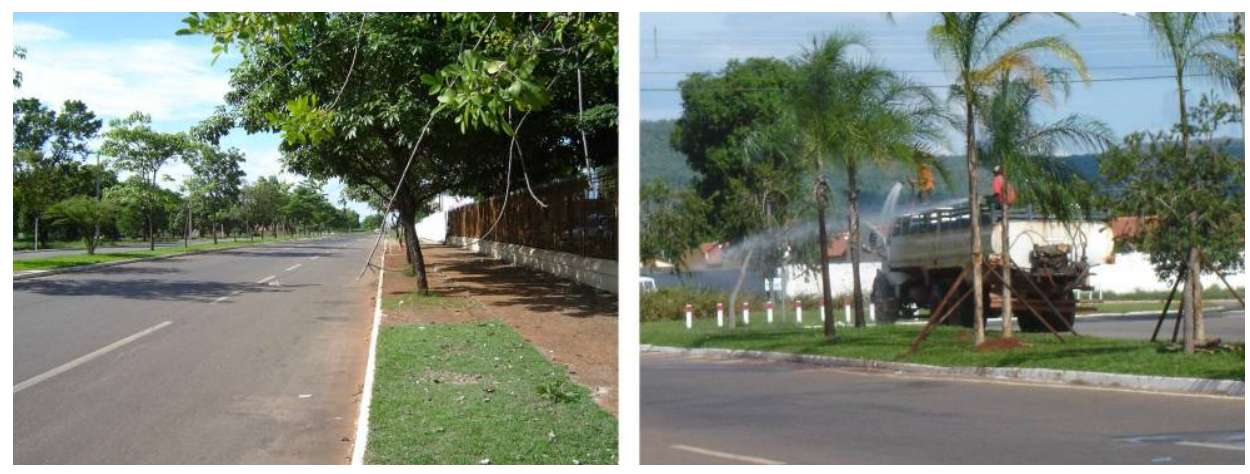

Fig.135, Pa isa gem das avenidas a rteria is na região central. Caminhão pipa aguando os jardins dos canteiros das avenidas na época seca, que corresponde de ma io a outubro.

(Fonte: a utor, 2006)

$\mathrm{Na}$ cidade, o espaço verde natural e o transfomado ora se contrapõem e se completam na formação da paisagem. A estética do cerrado foi gradativamente substituída. Transformação esta que teve um custo, ecossistêmico, social e econômico.

O sistema de espaços verdes de Palmas em parte já está delimita do pelo sistema viário e pelas áreas de preservação, independente de sua intervenção projetual. Amarrando esse sistema estão os espaços verdes de cada unidade de vizinhança, e que podem apresentar diferentes formas, dada à especificidade do desenho de cada quadra. Ocupando 9,9\% do total de 10.787 ha., os espaços verdes representam uma importante fração do parcelamento e do traçado da cidade. (SEDUH, 2005) 


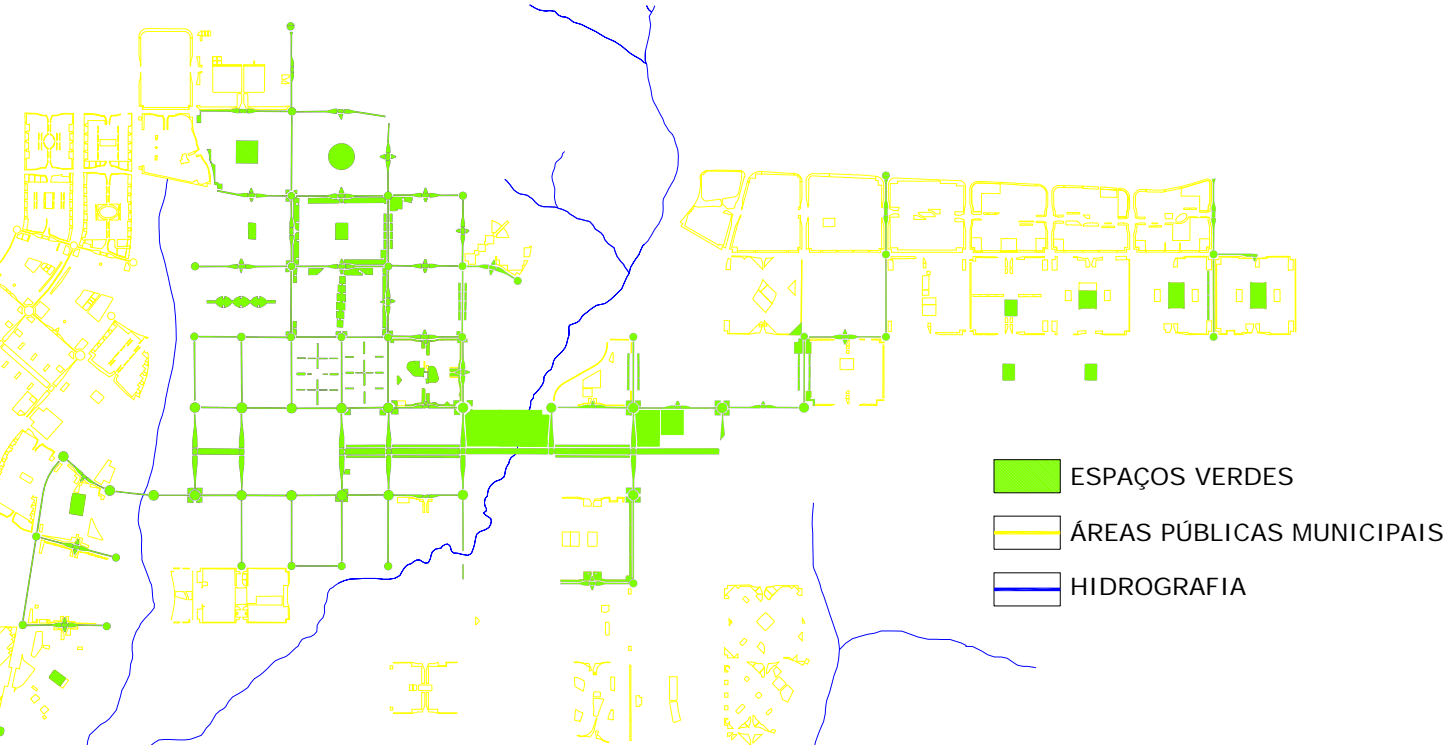

Fig. 136, Espaços verdes em Pa Imas. Na cor a ma rela as áreas públic as munic ipa is, um importante potencial para a criação de áreas verdes. (Fonte: SEDUH, 2005)

A Fig. 137 representa a caracterização dos espaços verdes das quadras centrais. A separação indica todas as formas em que estes se conformam, seja em áreas públicas, institucionais, particulares, no sistema viário, ou em áreas residuais do parcelamento.

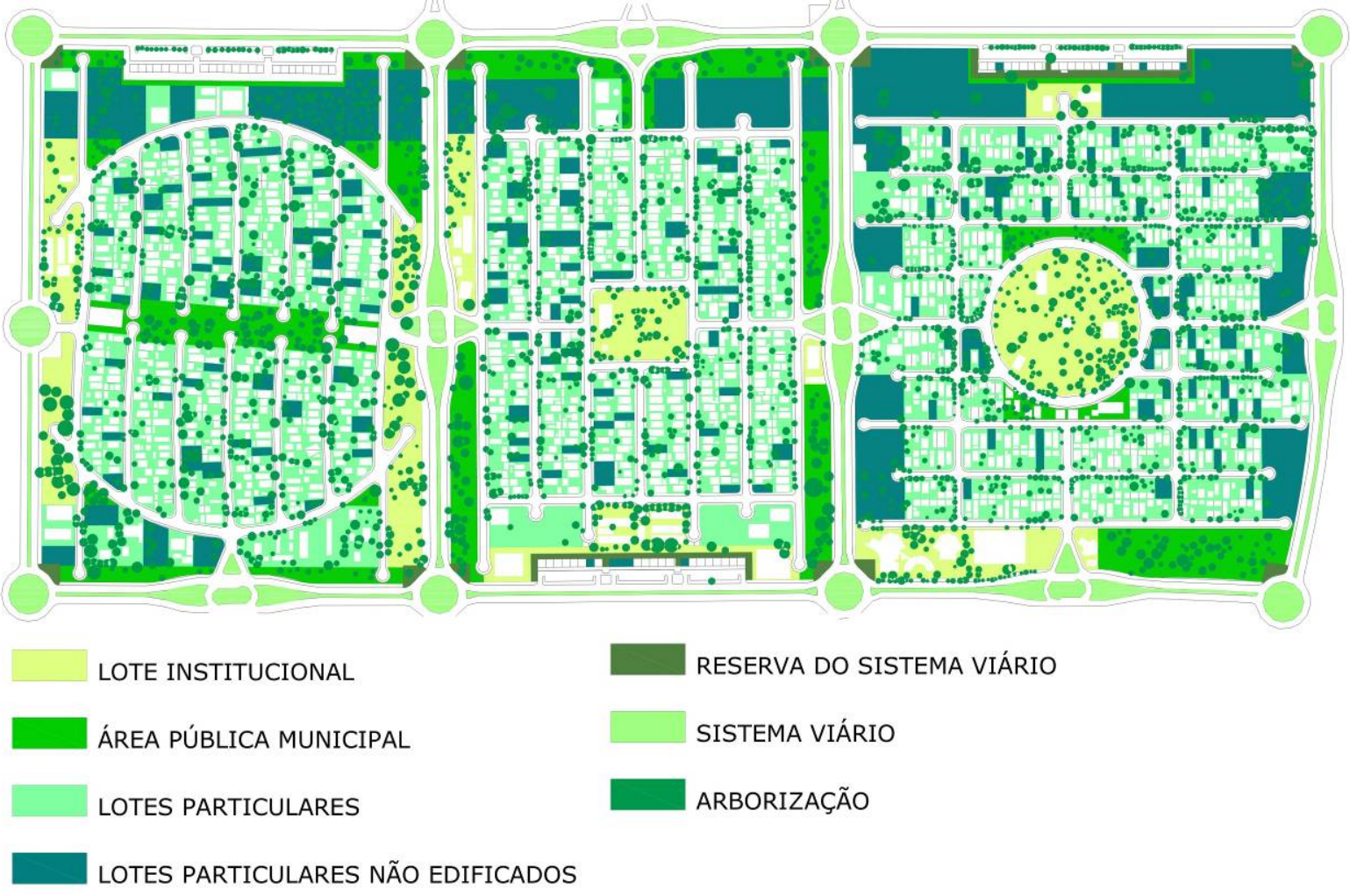

Fig. 137, Caracteriza ção dos de Espaços Verdes na região central. (Fonte: a utor, 2006) 
Essa grande quantidade de áreas verdes está sendo gradativamente utilizada pelo poder público, porém algumas ainda se mantêm praticamente intocadasou com pouca intervenção humana. O processo de construção do espaço verde da Avenida Teotônio Segurado, apresentado no Capítulo 03, se estendeu por praticamente toda cidade, definindo as principais categorias de espaços verdes que se configuraram, caracterizando esse sistema. Este se divide em três categorias:

1)Espaços onde a vegetação nativa foi totalmente retirada e constituiu-se uma nova a rquitetura paisa gístic a com outras espécies;

2)Espaços onde a vegetação nativa foi incorporada em novos projetos de a rquitetura paisa gística;

3)Espaços onde a vegetação nativa foi parcialmente retirada e não houve intervenção projetual;

A capacidade de cada um em promover interações e se conformar com lugar, está relaciona do com a forma com que estes foram apropriados, independentemente de sua condição projetual.

A primeira engloba principalmente os canteiros e rotatórias do sistema viário e algumas áreas públicas municipais. A arborização das ruas, de responsabilidade de cada morador, se caracteriza muitas vezes por apresentar intervenção projetual, onde o tratamento urbano e paisagístico é feito pelo morador do lote. Esse conflito entre apropriação privada em área pública, assim como ocorre em muitas cidades, é responsável pela má utiliza ção das calçadas em Pa Imas. A segunda engloba alguns espaços que preservaram árvores mais relevantes, incorporadas a um novo desenho da paisagem. A terceira se caracteriza pelos espaços públicos e lotes particulares que a inda não ocupados.

As duas áreas objeto de estudo apresentam as três categorias de espaços verdes, e o objetivo é identificar o grau de urbanidade de cada uma e sua relevância quanto a esse sistema, aferindo-as a condição de lugaresem meio à trama urbana.

A primeira categoria de espaços verdes, a que foi totalmente altera da, ocorre na região central principalmente junto a o sistema viário (Fig. 
138). A vegetação original foi totalmente removida para abertura das avenidas e quadras, substituídas por outras espécies, tanto nos canteiros centrais e como nas calçadas laterais. As quadras centrais a presentam o paisagismo das avenidas como principal marco e imagem da condição estética da cidade.

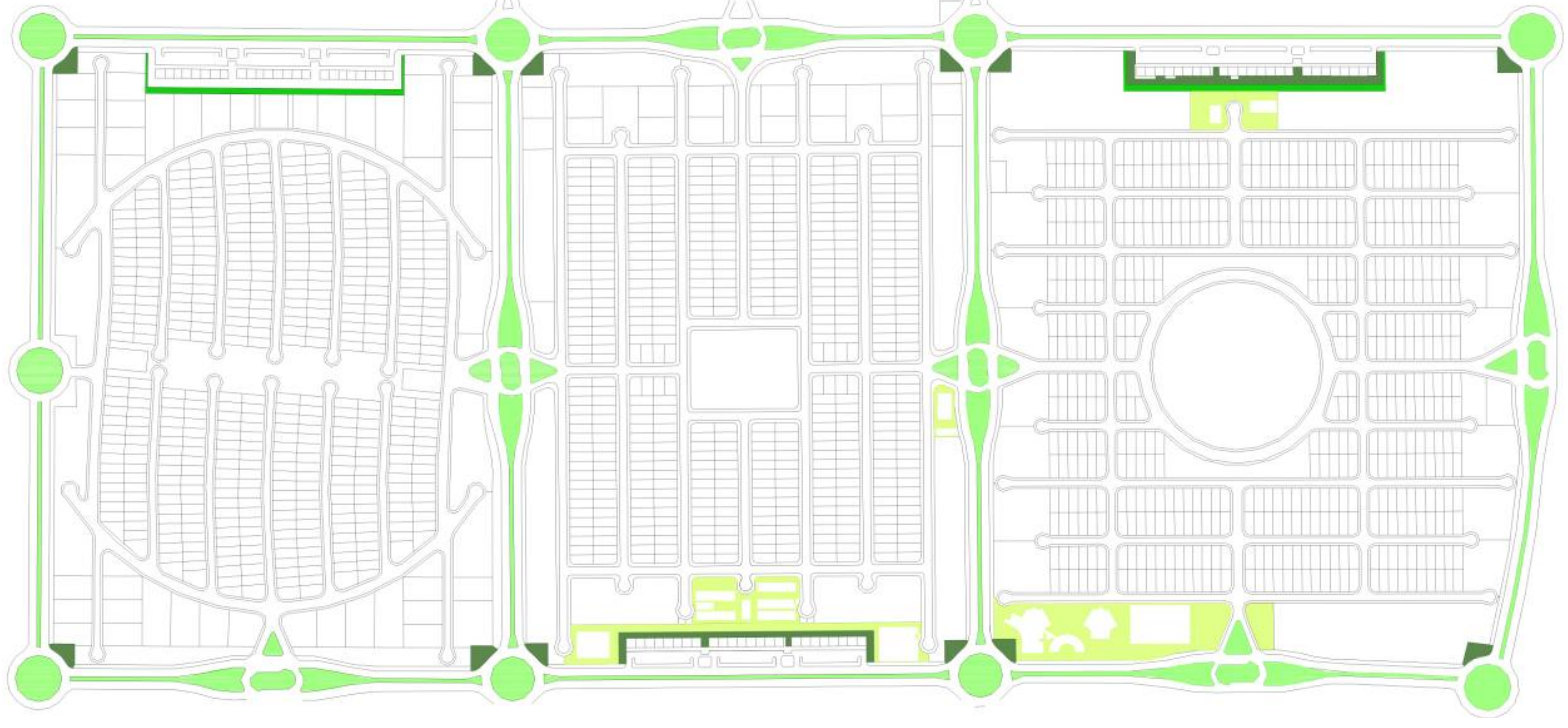

Fig. 138, Espaços verdes tota Imente modific a dos: região central. (Fonte: a utor, 2006)
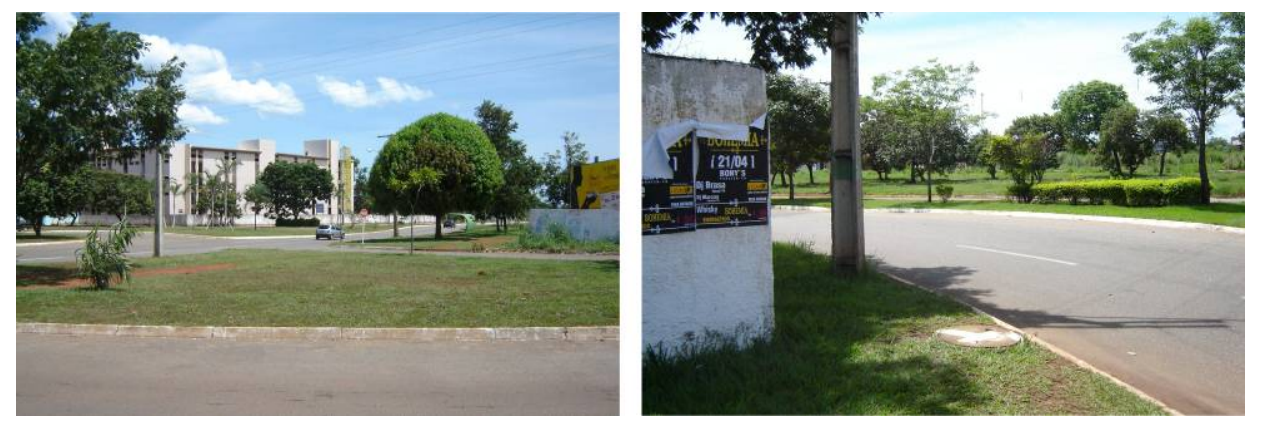

Fig. 139, Espaços verdespertencentes a o sistema viário de Palmas. Acesso à quadra e reserva do sistema viário na Arse 13. (Fonte: autor, 2006)

As rotatórias caracterizam-se pela criatividade das formas de seus jardins. Esse importante coeficiente de áreas verdes da cidade se configura apenas como um nó viário, sem nenhuma apropriação pública que gere interações, delimitando e ordenando esse sistema. Elas não promovem nenhuma relação com o espaço ao redor, dificultado pelo acesso de 
pedestres, e prejudicado pela falta de interfaces existentes com outros elementos do contexto urbano.
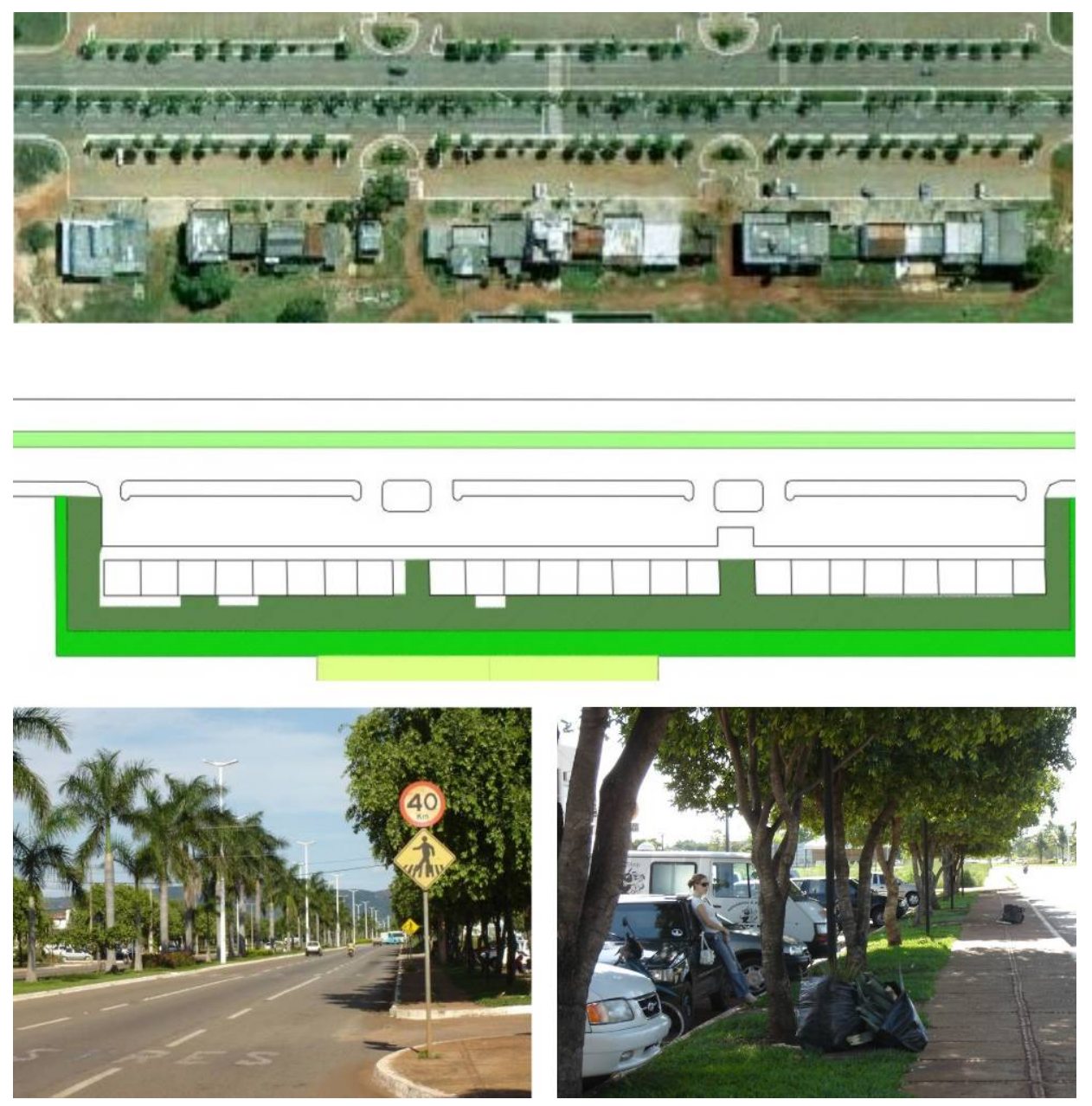

Fig. 140, Canteiros centra is e passeio de pedestres na Arse14. (Fonte: a utor, 2006)

Outras áreas totalmente modificadas são as áreas de expansão do sistema viário. Estas correspondem a uma pequena fração, porém sua localização estratégica permite uma importante conexão com o espaço livre das unidades de vizinhança, que muitas vezes estão limita das por muros de lotes residencia is.

A segunda categoria de espaço verde se caracteriza na região central pelas praças, por algumas áreas institucionais, e por áreas públicas junto ao sistema viário. Esses pontos de atratividade são formados por projetos paisagísticos que adaptaram e incorporaram algumas espécies relevantes da vegetação nativa. Essa transformação parcial não impediu 
que muitas árvores e arbustos fossem retirados, modificando a condição ecossistêmica, e principalmente o micro clima local.
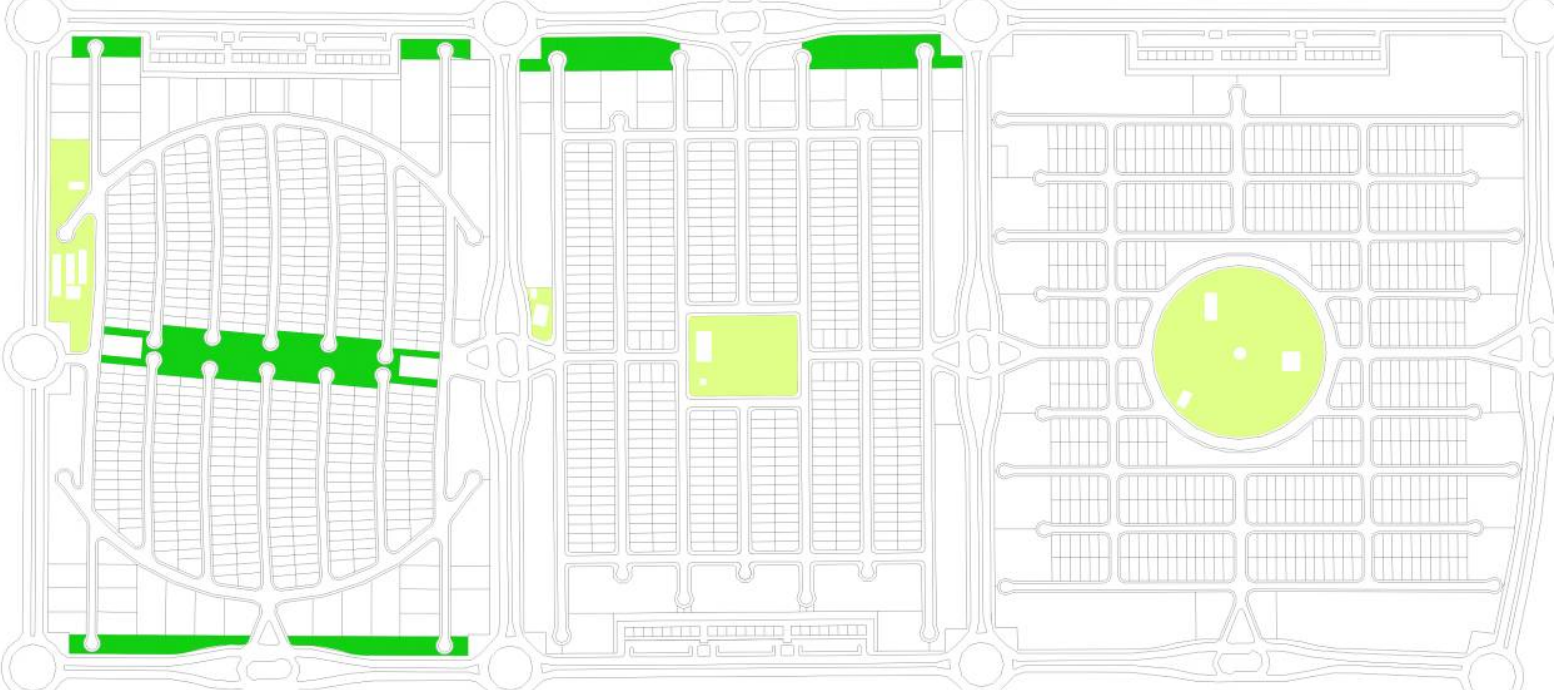

Fig. 141, Espaços verdes que sofreram intervenção projetual mas a proveita ram o potencial paisa gístico da vegetação nativa. (Fonte: autor, 2006)
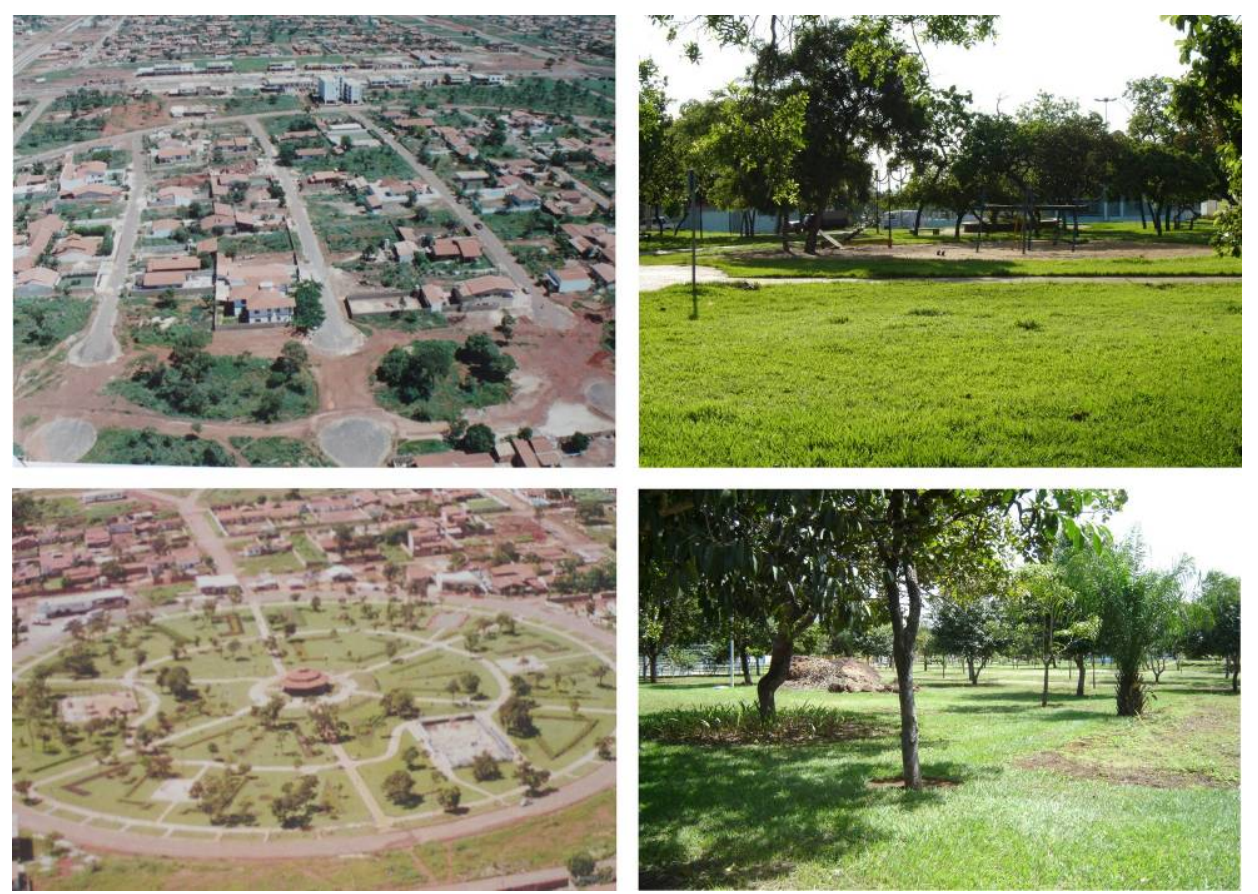

Fig. 142, Área da Praça da Arse12 sem intervenção com as espécies nativas que serão aproveitadas pelo projeto paisa gístic o. Praça da Arse12 já implementada. (Fonte: SEMUC, 2006; autor, 2006)

Esse tipo de intervenção fez com que esses espaços verdes apresentassem não só uma melhor qualidade projetual, mas uma ligação 
direta com alguns elementos que formam a paisagem local, criando uma identidade junto à do cerrado. Essa relação tem influência direta na forma de apropriação destas. Os resquícios da formação natural aparecem em alguns pontos dos projetos, como na Fig. 142, constituindo luga res a prazíveis para o convívio e relações socia is.

A capacidade da vegetação do cerrado em se constituir como lugar, gerando uma presença mais efetiva dos moradores, e utilização do espaço de propriedade pública, é fruto da composição e da identidade da paisagem, onde esta se destaca como um fator preponderante para a formação do senso de pertencimento local. As principais concentrações de pessoas estão nestas áreas, localizadas à sombra de árvores nativas, como as Faveiras de bolotas, Pequizeiros, Cajueiros, Acácias e outras espécies que são encontradas no cerrado.
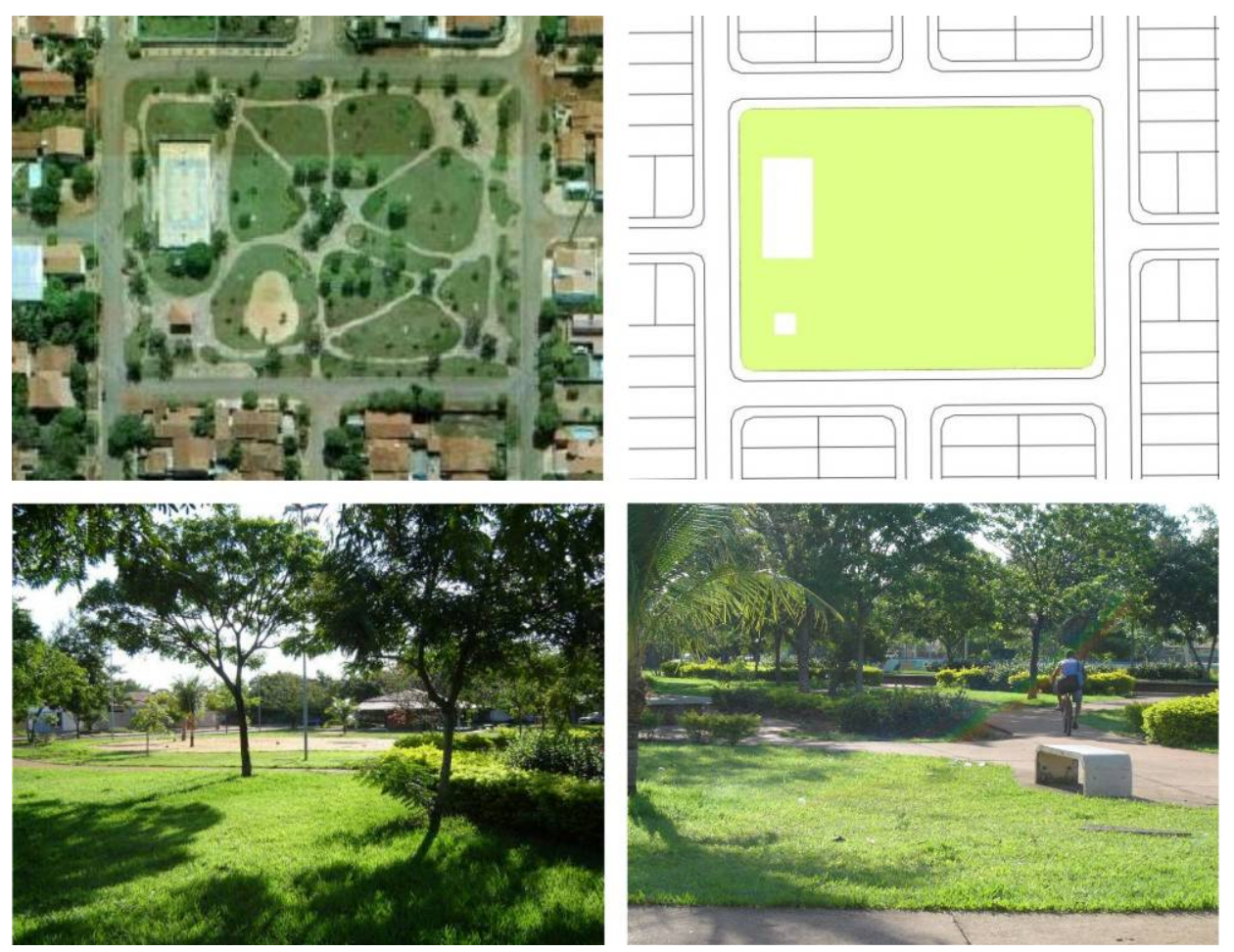

Fig. 143, Praça da Arse13 com sua vegetação nativa incorporada ao projeto paisagístico. (Fonte: a utor, 2006)

A terceira categoria de espaços verdes encontra-se em grande quantidade na área central, e é responsável por um tênue limite entre projeto urbano e apropriação. Os espaços de propriedade pública que não 
sofreram interferência de projeto, se moldaram ao plano da cidade, e representam um importante coeficiente para a manutenção da qualidade urbana local.

Muitos terrenos particulares não edificados e áreas públicas se encaixam nesta categoria, deixando algumasárvorese parte da vegetação rasteira. A capacidade do cerrado em se regenerar é conhecida, e nesses terrenosa vegetação cria uma importante zona de conforto, principalmente para os pedestres, que os utilizam para o acesso a outros pontos da quadra e como pontos de permanência. Esses se caracterizam por uma apropriação pública, condicionados a sua melhor ambiência urbana e como elemento da estrutura de espaços livre. A sua disposição na Fig. 144 demonstra a potencialidade deste elemento para a conjuntura urbana local.

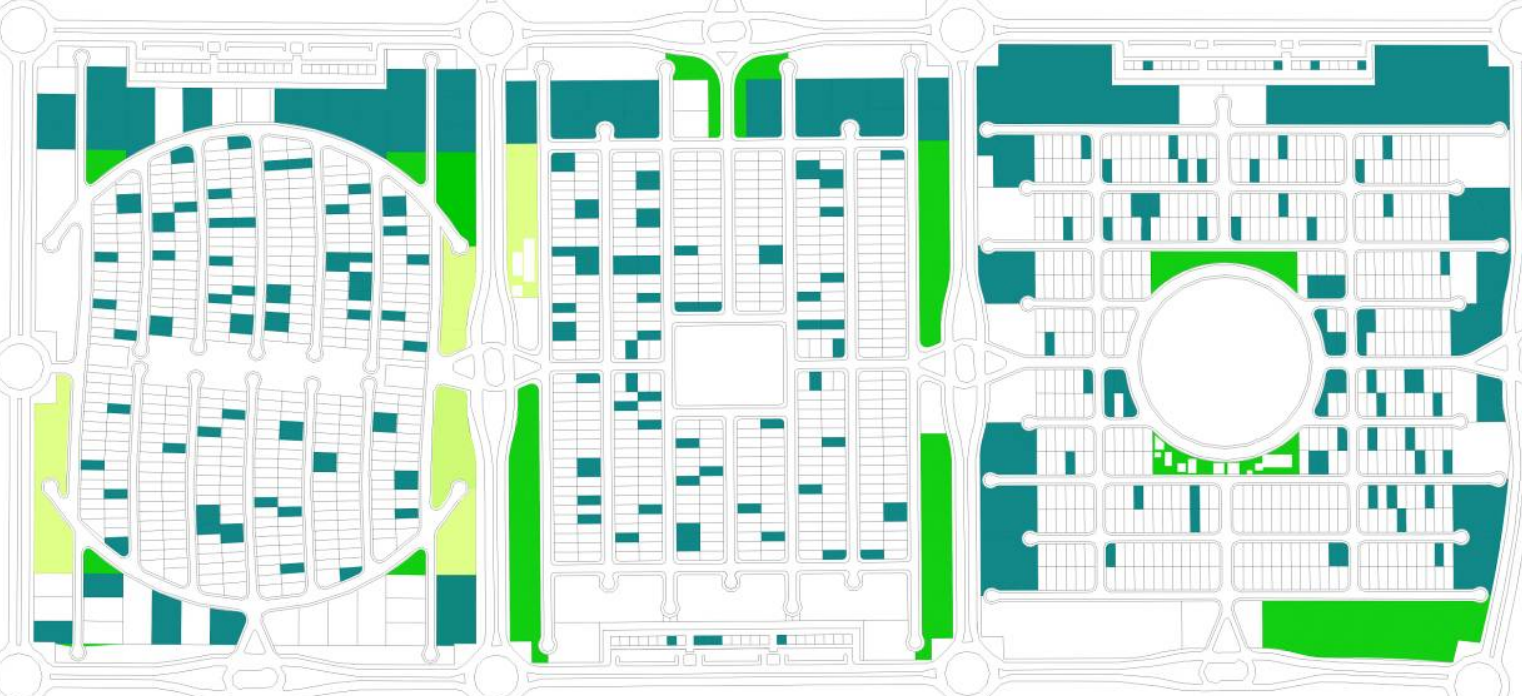

Fig. 144, Espaços verdes que não sofreram intervenção projetual e a vegetação nativa foi parcia Imente retira da. (Fonte: autor, 2006)

Nessas áreas, o fato de não haver o mesmo tratamento paisagístico, implica na redução doscustos de manutenção, na apropriação espontânea e em uma outra composição da paisagem urbana. Espécies nativas inscrevem na paisagem os ciclos naturais da vegetação, do solo e da condição climática local. 

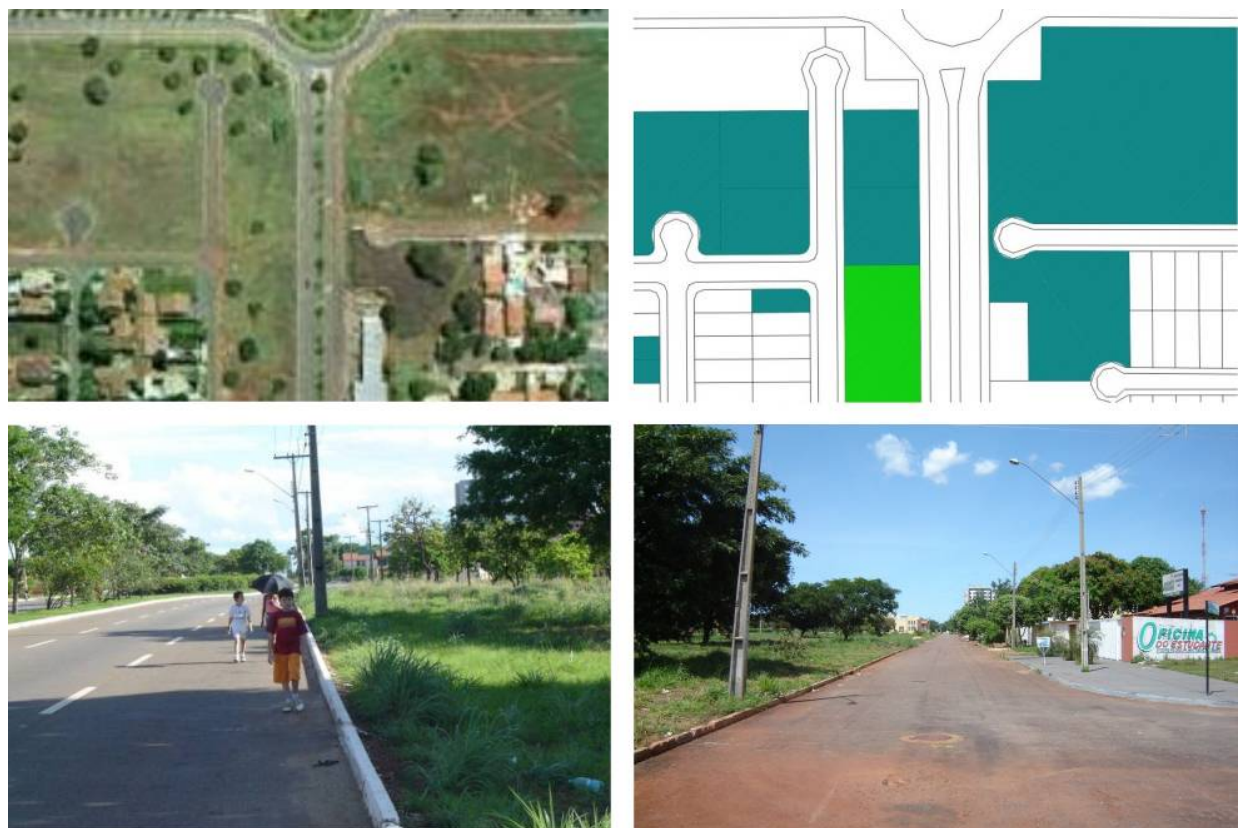

Fig. 145, Espaços verdes sem intervenção projetual. Na foto áreas particula rese públic as se fundem criando um sistema de espaços livres na cidade. (Fonte: a utor, 2006)

O maciço arbóreo das quadras centrais (Fig. 146), se configura por uma maior concentração de árvores nas calçadas, porém ainda pouco explorado em relação à generosidade de espaços destinados a esse elemento. Pode-se ler o traçado das quadras através dessa arborização. Nos residencia is há uma pequena concentração de árvores no seu interior. A grande quantidade de piscinase áreas de lazerfazcom que o terreno tenha uma outra conforma ção pa isagístic a, com a rbustos, pa lmeiras e gramíneas.
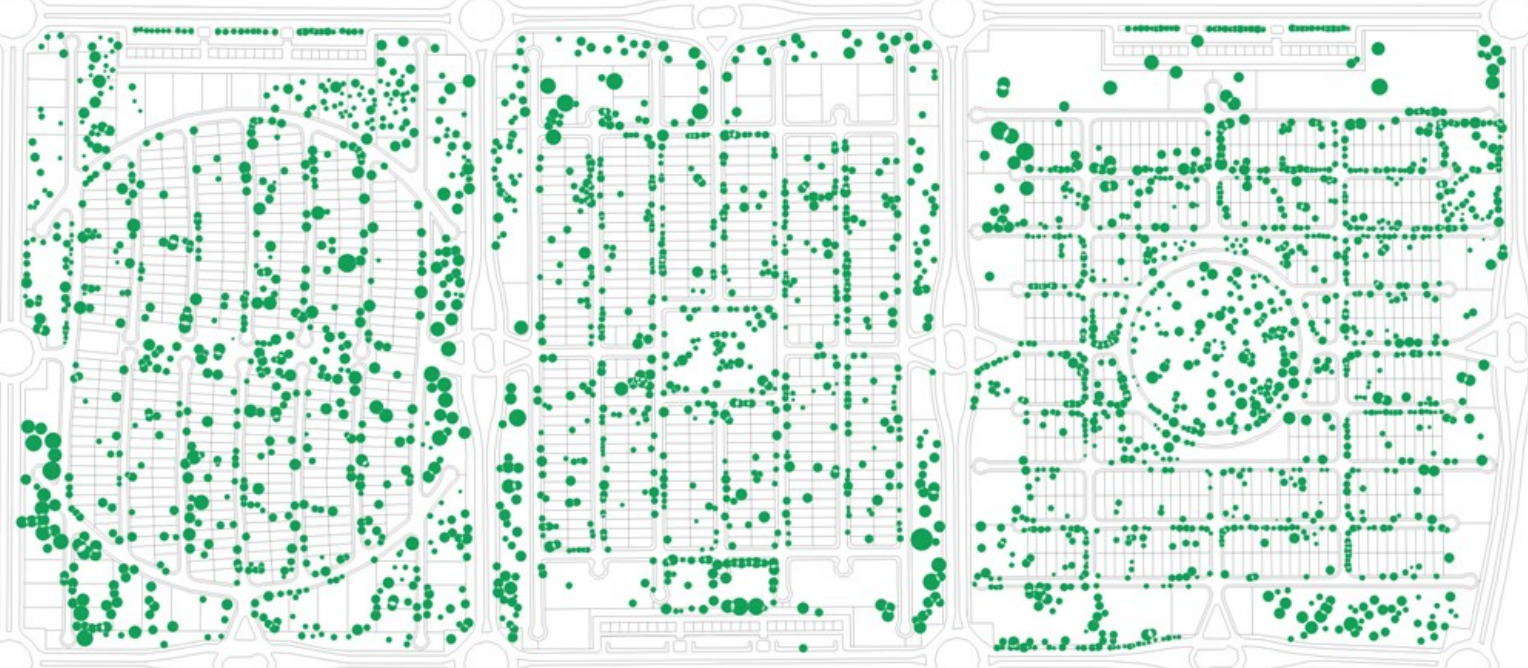

Fig. 146, Arborização das qua dra s centra is. (Fonte: a utor, 2006) 

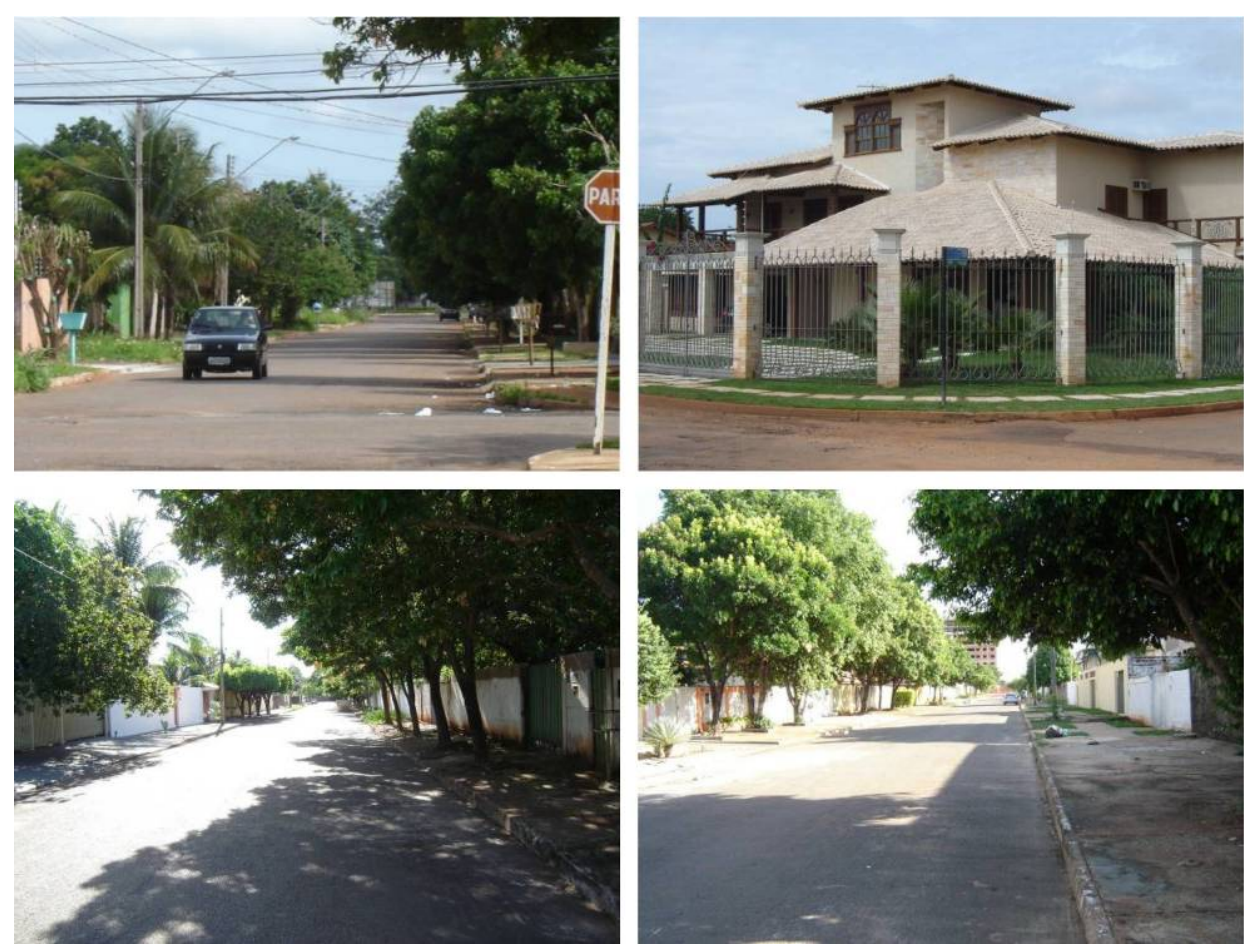

Fig. 147, Arborização nas calça das da região central. (Fonte: a utor, 2006)

Em muitos locais, a arborização privilegia espaços que não tem um fluxo intenso de pessoas. Os canteiros centra is das avenidas são repletos de árvores de grande porte, enquanto que no passeio não há uma arborização adequada às condições témicas locais. Muitos fluxos estão atrelados ao sistema de arborização existente em cada quadra.

A Vila União apresenta as mesmas porcentagens de espaços livres verdes, porém se configurando morfológica e espacialmente de modo diferenciado. A presença de maciços arbóreos em lotes particulares, com uma forte presença destas nos fundos dos lotes, cria um importante coeficiente ambiental para a área. Esses são frutos do perfil cultural dos moradores, onde quinta is com árvores, muitas vezes frutíferas, sem projeto pa isa gístico, dominam esses espaços.

Em contrapartida, a a rborização nas calçadas da Vila União não apresenta a mesma confomação, sem a mesma relevância cultural, tomando a paisagem das ruas diferenciadas. As ruas estreitas e a arboriza ção nos terrenos dos lotes denotam uma outra condição e um outro signific a do para a paisagem. A Fig. 148 mostra essa distribuição. 


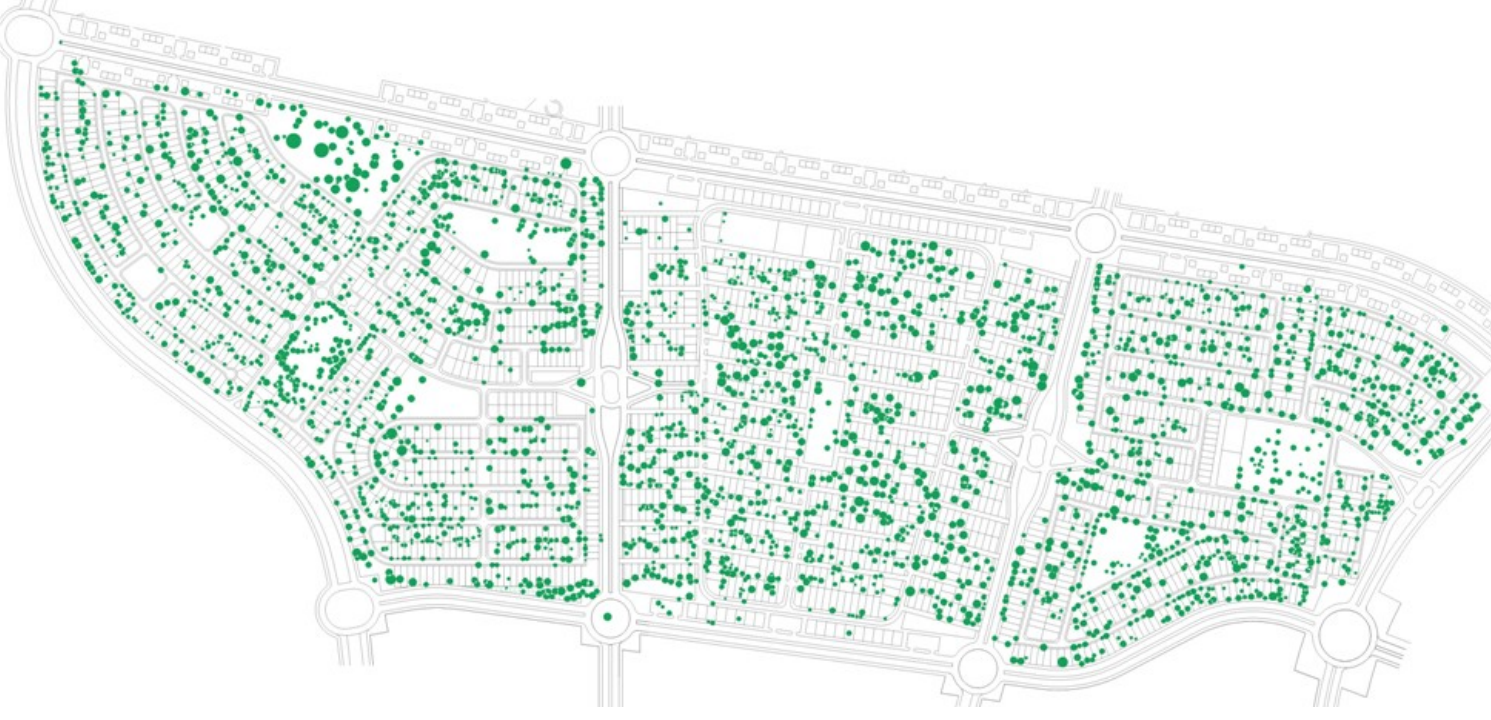

Fig. 148, Arboriza ção na Vila União. (Fonte: autor, 2006)
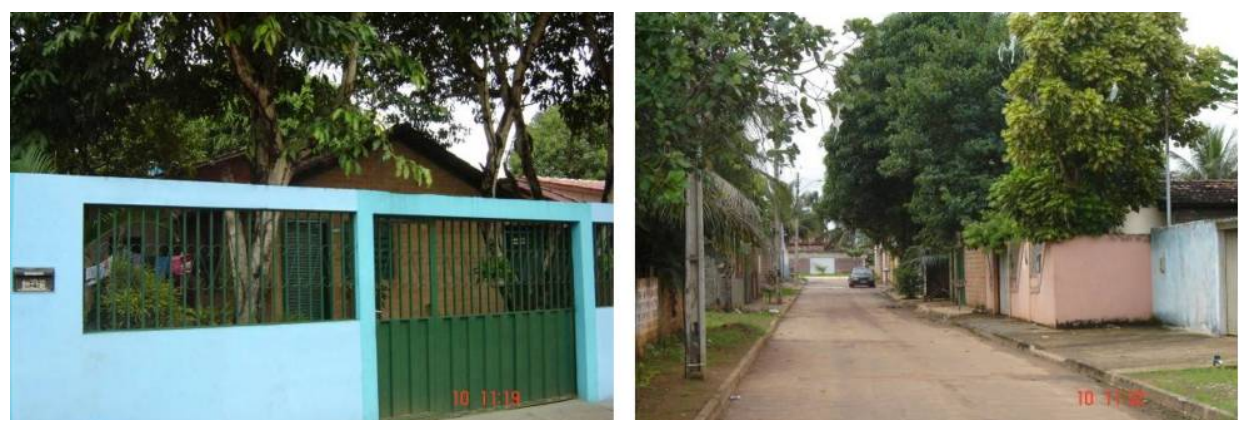

Fig. 149, Arboriza ção nos lotes partic ula res da Vila União. (Fonte: a utor, 2006)

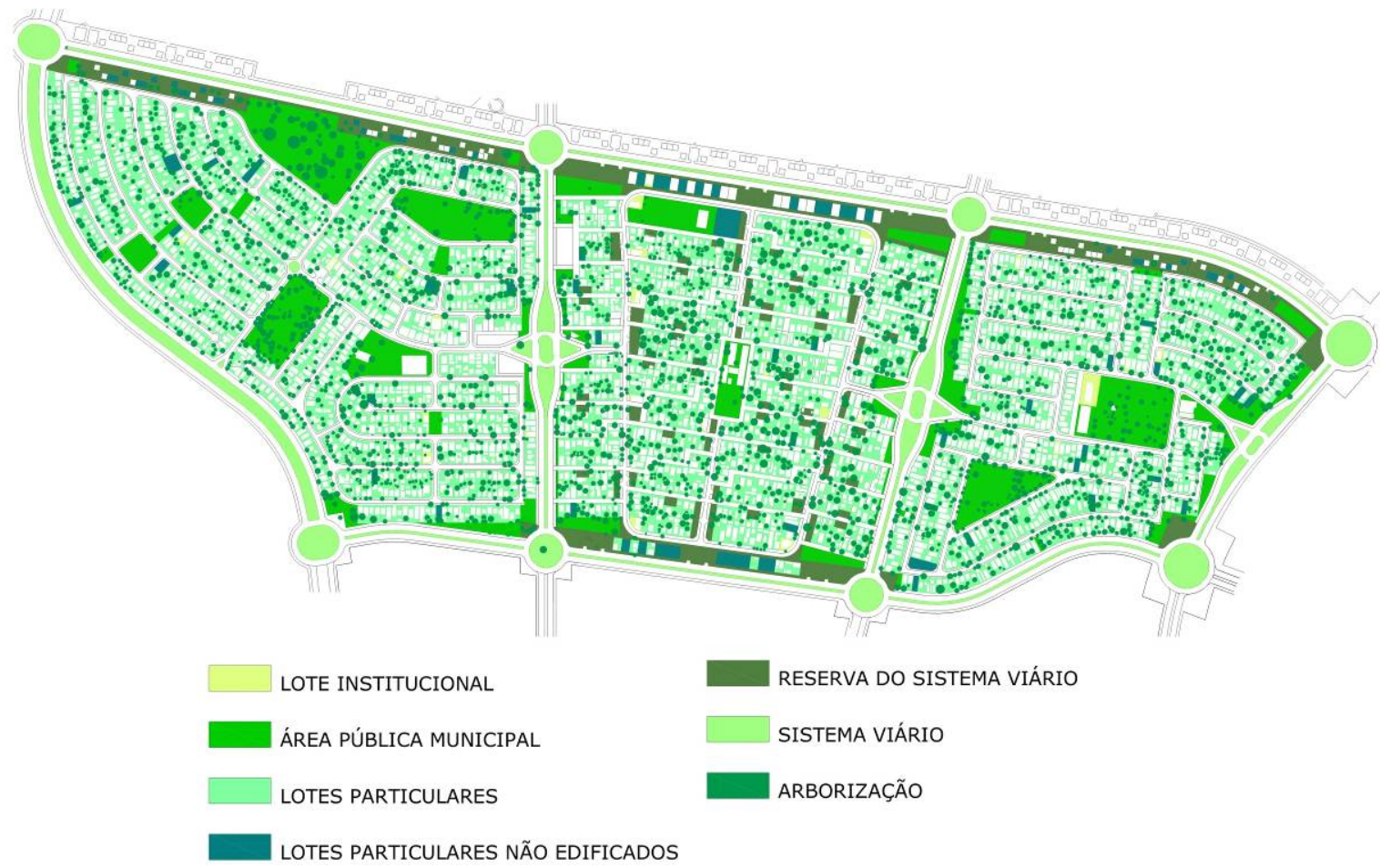

Fig. 150, Ca racteriza ção dos Espaç os Verdes na Vila União. (Fonte: autor, 2006) 
Grande parte da vegetação existente foi modificada. A foma de ocupação, com muitas pessoas se apropriando e tendo que tomar posse do lote, promoveu uma alteração no contexto ecossistêmico local. À medida que as quadras começaram a ser estruturar, uma nova vegetação foi se conformando, e somadas as ánores remanescentes, configuraram os espaços verdes da região.

A primeira categoria, onde a vegetação foi totalmente retirada, se encontra principalmente nos canteiros e rotatórias. Esses, não exibem a mesma diversidade de espécies e o mesmo cuidado que marca a imagem paisagística da cidade. Os gramados e as árvores recém plantadas delimitam não somente as quadras, mas os limites do plano, insc revendo na paisagem a dialética entre projeto e cultura.

Fig. 151, Espaços verdes modific adose com nova vegetação. (Fonte: a utor, 2006)
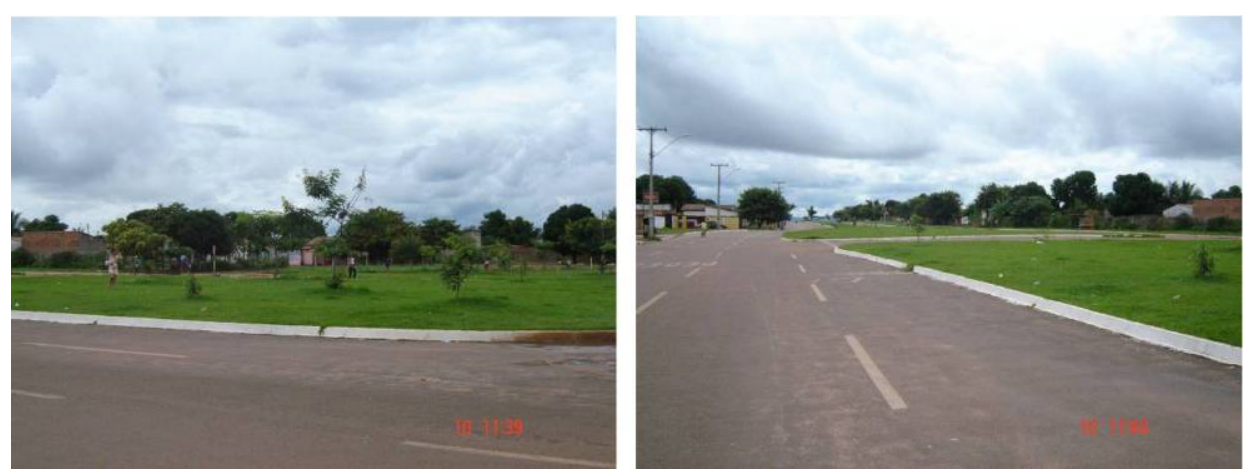

Fig. 152, Canteiros centra is das a venidas na Vila União. (Fonte: a utor, 2006) 
A segunda categoria se evidencia nas duas praças da Amo 31 e 33.0 projeto paisagístico seguiu o mesmo padrão das quadras centrais, com árvores nativas de relevância estética, cultural e ambiental, preservadas, e incorporadas ao novo desenho. O projeto foi um instrumento para equiparar espacialmente as áreas públicas da Vila União às centrais, transferindo a identidade e ima gem da cidade ideal a tra vés de intervenções pa isa gísticas.

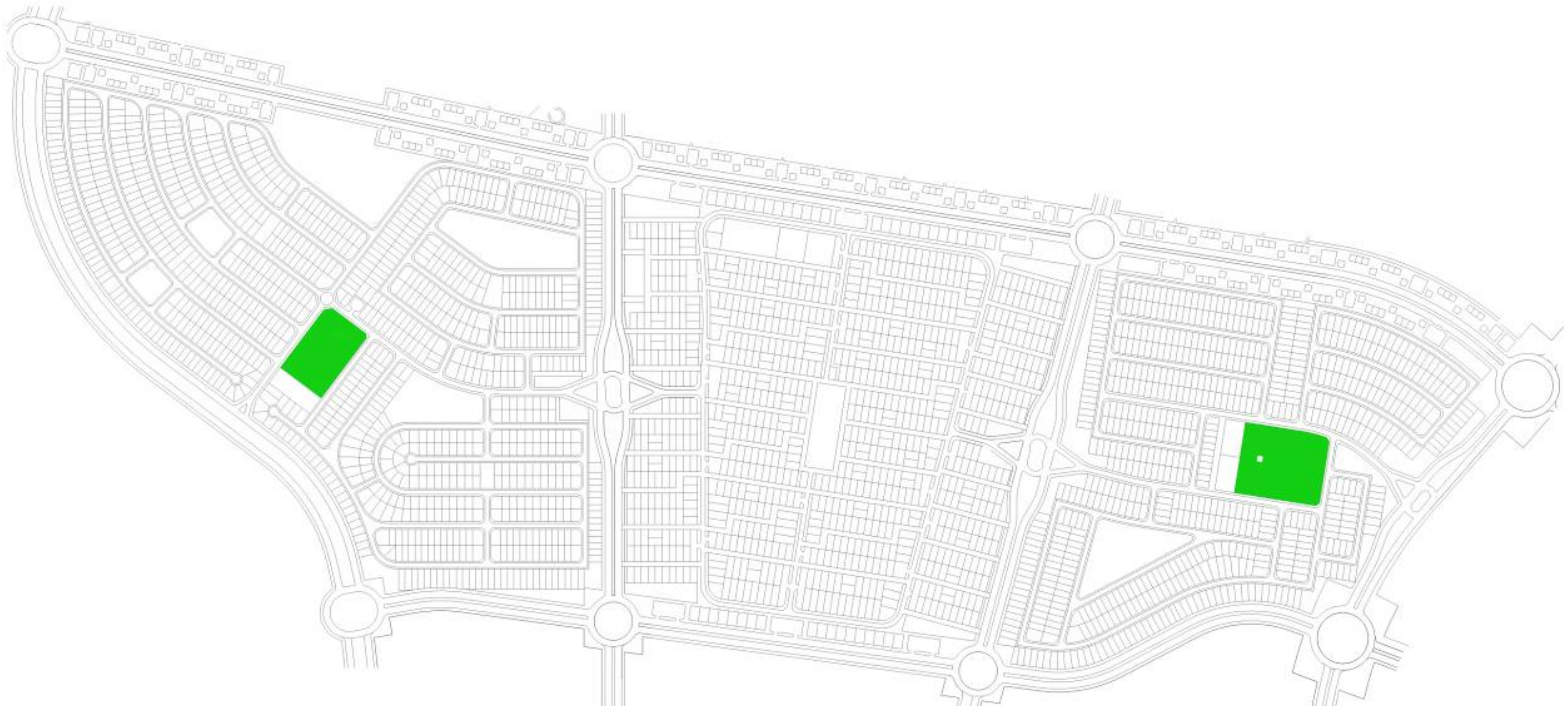

Fig. 153, Espaç os verdes que sofreram intervenção projetual mas a proveitaram o potencial paisagístico da vegetação nativa. (Fonte: autor, 2006)
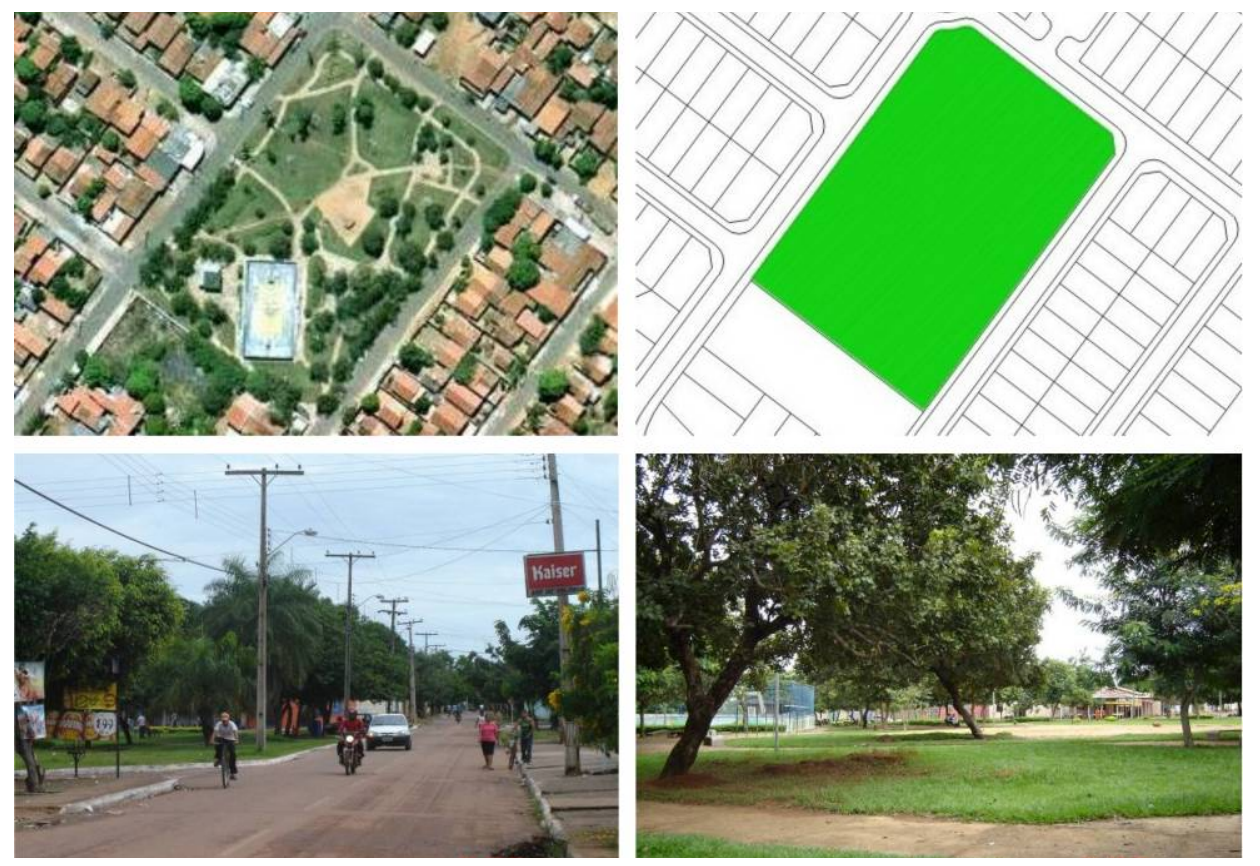

Fig. 154, Praça central da Amo 33. O projeto paisagístico segue o modelo de desenho de outras praças da cidade. O aproveitamento da vegetação no projeto aumentou a qualidade do local, que é a propriado pelos moradores. (Fonte: autor, 2006) 
As áreas onde se fomaram os centros comerciais a presentam poucas árvores, principalmente nos acessos às quadras, diferenciando-se da região central, onde existe uma maior concentração de vegetação. Mesmo assim, são lugares do encontro e das relações socia is.

A terceira categoria é essencial para a dinâmica do espaço. Áreas sem intervenção projetual formatam a paisagem e criam um sistema onde a apropriação espontânea molda as práticas sociais. Este fa to configurou uma esfera pública essencial para a urbanidade, não pela ausência do projeto em si, mas pela possibilidade e visibilidade da apropriação cultural que insc reve seus ritos, fluxose necessidades.

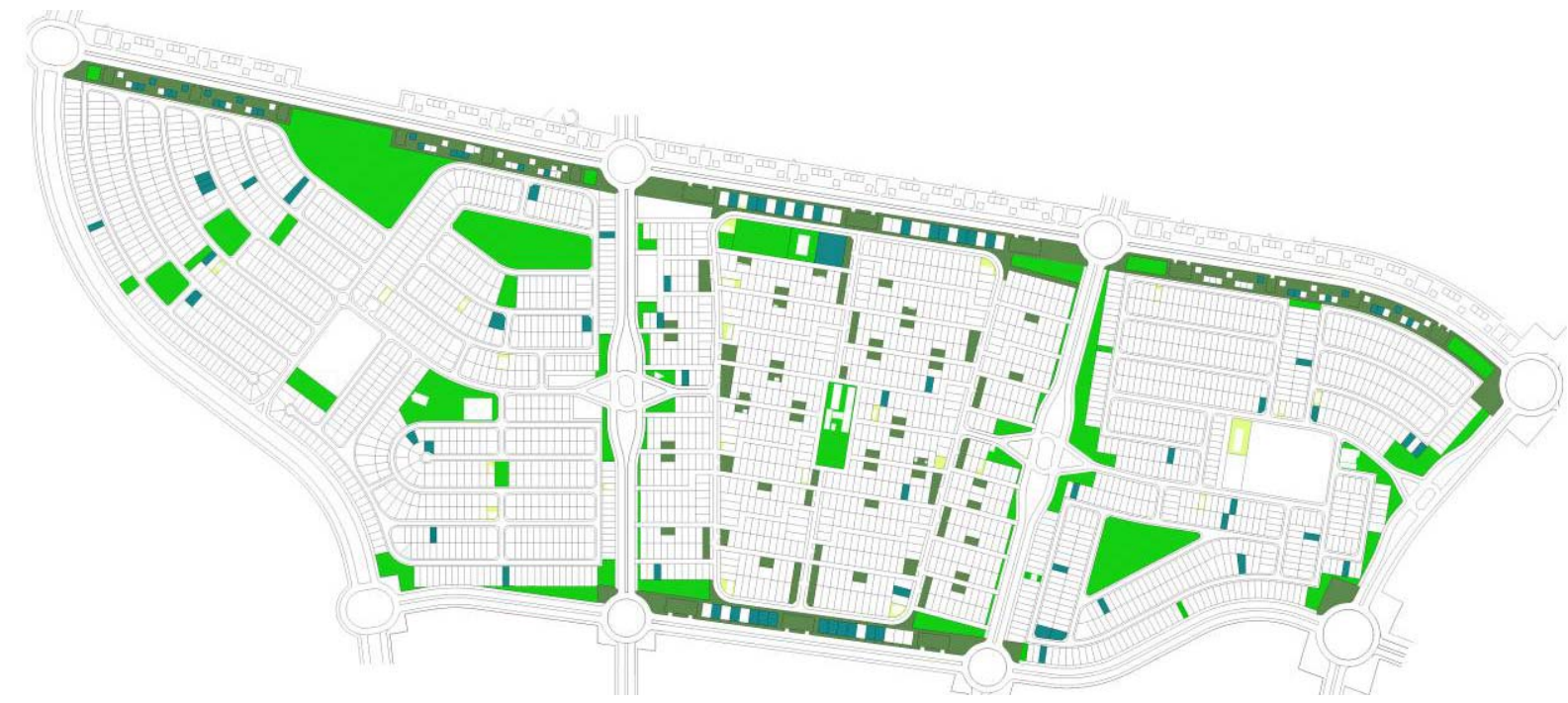

Fig. 155, Espaços verdes parcia Imente modifica dose sem intervenção projetual. (Fonte: autor, 2006)

Diferentemente da região central, onde esse tipo de espaço verde se divide igualita riamente entre espaços públicos e privados, na Vila União elas se concentram nas áreas públicas munic ipais. O projeto urbano das quadras previu uma grande e diversificada quantidade destas, propiciando diferentes formas de apropriação. Muitas destas se encontram em meio aos caminhos percomidos pelos moradores para as diversas centralidades criadas pela contra posição ao plano, fazendo com que muitas se to massem pontos de concentração e pemanência dos moradores. 

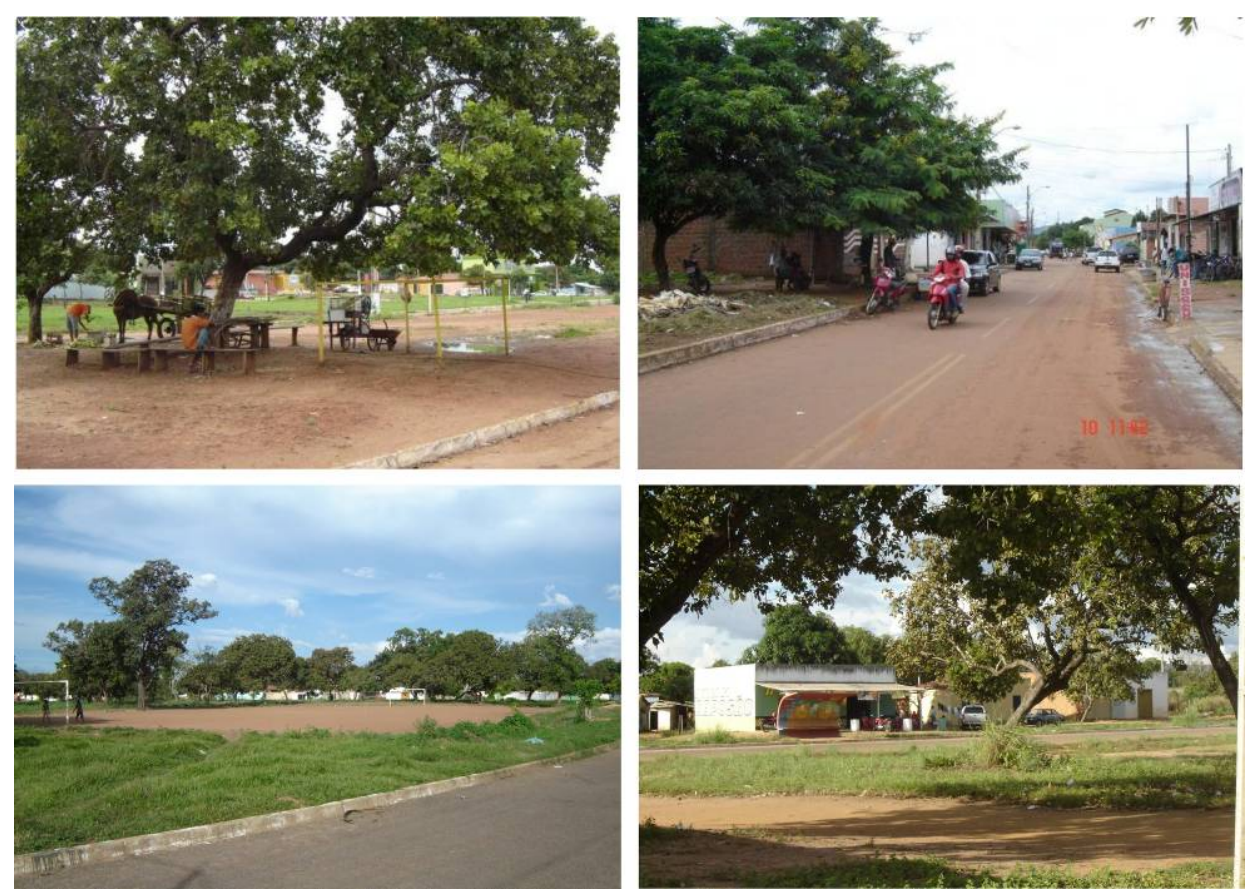

Fig. 156, Cenas do cotidia no e dos espaç os livres sem intervenção projetual, porém com intensa a propriação dos moradores. (Fonte: autor, 2006)

A riqueza de apropriações nestas áreas permite maior legibilidade da dinâmica social e das relações que se evidenciam. A condição para a urbanidade não é projetual, é identitária, histórica e relacional, assim como o lugar, que transmite uma riqueza de informações essenciais para a sua condição qualitativa. 


\section{Consideraçõ es Finais}

Os limites do projeto urbano são potencialidades, interfaces de uma articulação entre a prática de profissionais, que inscrevem os conhecimentos adquiridos pela sociedade e os condicionantes culturais que inscrevem os deteminadosmomentos da sociedade.

O espaço urbano de Palmas é um grande laboratório criado pela apropriação humana em meio a uma paisagem natural. Vivenciar o processo de construção de uma nova cidade é uma experiência participativa que permite diferentes olhares sobre o mesmo lugar. As categorias elencadas para demonstrar uma deteminada caracteństica de sua conformação não revelam a totalidade de potencialidades que este propicia e propiciará, à medida que a relação tempo-espaço produz e produzirá, novos contextos e cenários capazes de inserir novas marcas, novas conformações desta paisa gem.

As ca tegorias demonstra ram que nas duas regiões de estudo, os limites estão articulados com as práticas culturais de apropriação, que se evidenciam no espaço. A qualidade deste, ou urbanidade, é aferida pelas interfaces existentes entre as insc rições físic as e abstratas que denotam uma dinâmica própria à cidade. O misto de determinismo e espontaneidade introduziu uma nova realidade no cotidiano de seus moradores, revelando os conflitose contra dições que ocorrem no espaço.

“A cidade não é o seu projeto. Ela é muito mais o produto de seus cidadãos; não pertence a ninguém em particular, nem aos que a planejam, nem aos seus iniciadores." (PLANO BÁSICO/MEMÓRIA,, 1989)

As palavras dos autores de Palmas na citação a cima revelam um ideal inicial que dificilmente se viu na prática, a de eximir a concepção, a autoria do projeto, de seu processo de conformação. A revisão deste, com informações produzidas pelos condicionantes culturais, políticos e ambientais, devem refletir uma nova postura técnica e de gestão para a 
solução de problemas urbanísticos, devendo ser incorporados como elementos de sua produção.

O projeto urbano é necessá rio para a prática espacial assim como sua crítica. Mesmo com a crítica apresentada neste trabalho, os acertos são maiores que os erros em Palmas. As soluções de questões téc nicas e de infraestrutura necessária, e de uma ampla possibilidade de diferentes ambientes, revelam o discemimento da equipe que a projetou na tentativa de condicionar espaço a uma qualidade urbana promovida pelo projeto.

\begin{abstract}
“Projeto e crítica esforçaram-se em demonstrar que a apatia e a inconsistência constituem a própria essência da realidade em que vivemos e que, consequentemente, não há batalhas a combater assim como não se justifica a tensão para uma reconstrução de uma moral coletiva, como indispensável condição intemédia entre a moral individual e a ética das leis." (GIANGREGORIO, 2000, p 07)
\end{abstract}

O plano é uma possibilidade, não estática, de inscrever os desejos das sociedades. A identidade, o senso de pertencimento e a esfera pública são condicionantes para a consolidação do locus urba no em lugares. Estes, em Palmas, são determinantes para rever o processo de sua construção, revelando novas formas de proporcionar ao projeto uma qualidade que se evidencia porfatores cultura is, e não somente por seu ordenamento.

As unida des de vizinhança configuraram não somente o traçado, mas os diferentes processos de construção do espaço. Locus do cotidiano e exemplo de um urbanismo que definiu o seu modelo de desenvolvimento, evidenciam a história de uma sociedade em fomação. Parte desta está contida nas estruturas visíveis do plano, e parte nas estruturas invisíveis que determinam os ritos de seus moradores.

As análises demonstraram as diferenças dos processos de conformação entre as duas áreas. Dentre as categorias apresentadas, a múltipla centralidade revelou a importância de pontos de atratividade além dos previstos pelo plano, permitindo aos novos ampliar o uso público. Nas duas regiões, as centralidades representam os lugares de ma ior visibilidade 
pública das quadras, inserindo-as nas dinâmicas do cotidiano que as unida des possibilita m.

A conectividade é mais que uma possibilidade, é uma necessidade que se inscreve em diferentes pontos da cidade, seja pelo projeto ou por sua contraposição, marcando uma nova forma de apropriação dos espaços que rompem com as ba rreiras definidas para delimitar a ordem no plano. Em ambas as regiões as conexões revelam que a capilaridade do traçado urbano é uma qualidade que define as interações entre as centralidades. Tanto na Vila União, como na região central, elas ocorrem e promovem uma integração entre as diversas categorias de espaços livres existentes na cidade.

Os movimentos e as permanências garantem vitalidade a o espaço público. Embora estas ocorram com maior intensidade e continuidade na Vila União, a região central apresenta um grande potencial de transformação em função do aumento previsto de densidade, porém é necessário incorporar a lguns a spectos de integração entre as centralidades e possibilitar novos usos que garantam a diversidade de interações nas quadras. Somente sua intensidade não configura uma esfera pública no espaço livre, onde os fluxos podem ocorrer sem as trocas, enfraquecendo as relações sociais. Em locais onde o processo de construção apresentou um caráter comunitário, intensificando a participação, os movimentos e permanências a presentaram uma outra dimensão, possibilitando a inscrição de lugares, identitá riose relaciona is. Esse fa to ocorre na Vila União.

Sob esta ótica, a integração entre o espaço livre e arquitetura é essencial para possibilitar uma maior interação entre as esferas pública e privada. Seus limites referem-se à interloc ução entre as diferentes formas de arquitetura. Em Palmas há um hiato entre a qualidade dos espaços livres previstos pelo plano e a qualidade das edificações, que não se apropria da generosidade dos locais abertos para imprimir uma condição de unbanidade.

Esta lacuna inibe outras formas de apropriação do espaço público, formatando uma paisagem de muros pela cidade e não possibilitando as 
trocas, o contato, a escala gregária, a condição estética e cultural dos edifícios, e a legibilidade da paisagem. Construído e livre são objetos que necessitam uma interface direta, tanto física quanto social.

Em Palmas, algumas barreiras produzidas pelo plano não possibilitam que essas ocorram de forma a garantir a qualidade do seu espaço. O seu contraponto promoveu rupturas, principalmente na Vila União, onde a apropriação gerou uma nova condição de uso e uma nova organização temitorial, alterando as interações entre espaço e sociedade. Estas condicionam as dinâmicas socia is que determinam uma esfera pública mais efetiva nos espaços livres.

As categorias de espaços verdes revelaram a integração de fatores cultura is para a transformação de espaços públicos em lugares. A escala de muitas praças, a desconexão com o traçado urbano, e as barreiras impostas pelo desenho, denotaram a necessidade de uma maior interlocução entre a generosidade de espaços verdescom outros elementos os configuram.

A tese, que a urbanidade se conforma nos limites do projeto urbano e dos processos sociais, revela a importância dos fatores culturais e antropológicos, no processo projetual dos espaços urbanos. Construir uma cidade é uma tarefa inintemupta, onde os processos que a deteminam não são estáticos. É uma luta continua e muitas vezes desigual dos pensadores do espaço, que na busca de seu entendimento propõem melhorias que sintetizam diferentes graus de qualidade urbana em determinados momentos, mas que encontra nas variáveis que se inserem sobre as cidades, novas conformações.

Assim são os limites, potencialidades que apresentam as forças cultura is, inscrevendo a riqueza e os conflitos de cada sociedade, que se evidenciam no espaço e que transformam a ciência de sua produção em um processo contínuo.

A perspectiva de entender o ambiente urbano como um ecossistema, permitindo a leitura das relações entre seus elementos, traz uma contribuição necessária para a real manutenção e melhoria da qualidade da vida neste meio. Certamente não é a única. A a propriação da sua imbricação com as 
outras dimensões poderá desenhar uma outra urbanidade que, de forma progressiva, constitua uma visão com abrangência holística, onde estejam efetivamente incorporadas também as dimensões culturais, políticas e a mbientais.

Sem ingenuidade mas também sem cetic ismo, cada intervenção feita deve estar comprometida com os a tributos implícitos da urbanidade, para que seus limites passem a representar novos ca minhos de interloc ução entre espaço e sociedade. 


\section{Bi b I o g rafi a}

Plano básico/memória - G RUPOQUATRO, 1989

Revista Projeto n 146, outubro de 1991

ABALOS,I. O que é a paisagem? resenha arquitextos, revista eletrônica Vitruvius $n^{\circ} 049$, maio 2004

ACSELRAD, H. Discursos da sustentabilida de urbana. In: R. B. Estudos urbanos e regionais no. 1, p. 79-90, ma io 1999

ALVES, M. R. Notas de aula. Disciplina: Espaço, lugar e a cidade contemporânea. EESC-USP, Sã o Carlos, $2^{\circ}$ sem 2006

ANDRADE, L. M S. O conceito de Cidades-Jardins: uma adaptação para as cidades sustentáveis. Resenha arquitextos, revista eletrônica Vitruvius $n^{\circ} 042$, novembro 2003

ARANTES, O. Cultura e Transformação Urbana. São Pa ulo: 2000

ARANTES, O. O Lugar da Arquitetura depois dos Modemos In. São Paulo, EDUSP, 1993

ARANTES, O. Uma estratégia fatal: a cultura nas novas gerações urbanas. Sã o Paulo, 1998

ARANTES, O . Urbanismo em Fim de Linha. São Pa ulo: Edusp, 2001

ARENDT, H. A condição Humana. Rio de Janeiro: Ed. Forense Universitánia, 1981

AUGÉ, M. Não-lugares: introdução a uma antropologia da supermodemidade. Campinas: Pa pirus Ed itora,1994

AUGÉ, M. No-Lugares y Espacio Publico. in Quadems 231 - Water / Land. Barcelona, p. 06-15, 1997

BACON, E. Design of Cities. Lond on: Tha mes and Hud son Ltd., 1975

BARCEШOS, V. Q. Unidade de vizinhança: notas sobre sua origem, desenvolvimento e introdução no Brasil. Brasília: UNB, Cademos Eletrônicos da Pós- Paranoá, Volume 3, 2001

BAZOШ, J. A. Os efeitos dos vazios urbanos no custo de urbanização da cidade de Palmas., Pa Imas, 2007

BENÉVOLO, L. História da cidade. São Pa ulo: Perspectiva, 1999 
BORDA, L - O espaço recriado. São Paulo: Nobel, 1991

BRANDÃO, C. R. - A cultura na rua. Campina s: Pa pirus Editora, 1982

CALEIRA, T. P. do R. Cidade de muros: crime, segregação e cidadania em São Paulo. São Paulo : Ed. 34: Edusp, 2000

CALTHORPE, P. - The next american metropolis: ecology, community and the American dream. New York: Princeton a rchitectural press, 1993

CAPRA, F. As conexões oc ultas.Sã o Pa ulo: Cultrix, 2002

CARLOS, A. F. A. A (Re) produção do espaço urbano. São Paulo: EDUSP, 1994

CARLOS, A. F. A. A cidade . São Paulo: Editora Contexto, 1992

CARLOS, A. F. A. Espaço urbano e movimentos sociais. Boletim de Geografia Teoretica Rio Claro, v.22, n.43-4, p.147-53, 1992

CARLOS, A. F. A. Espaço: tempo da vida cotidiana na metrópole. Tese de livre docência, 2000

CARLOS, A. F. A. Meio ambiente urbano e o discurso ecológico. Revista do Departamento de Geografia. São Paulo, n.8 , 1994 p.75-8

CARLOS, A. F. A. Novas contradições do espaço. São Pa ulo : Contexto, 1999

CARLOS, A. F. A. O lugar no/do mundo. São Paulo: Hucitec, 1996

CARR, S. Public Spaces. New York: Ca mbridge University Press, 1992

CASEY, E. S. The Fate of Place: a Philosophical History. Berkeley: University of Califomia Press, 1997

CERTEAU, M. A invenção do cotidiano: artes de fazer. Petrópolis: Vozes, 1996 CONG RESS FOR THE NEW URBANISM Charter of the New Urbanism. EUA, 2000 COSTA, C. R. Z Ciências arcaic as do espaço. 1991

COSTA, H. S. M. Desenvolvimento Urbano Sustentável: Uma Contra dição de Temmos? - R. B. Estudo urbanos e regionais n. ㄴ 2, p. 55-71, ma rço 2000 COSTA, J. F. A personalidade somática de nosso tempo. In $\mathrm{O}$ vestígio e a aura: corpo e consumismo na moral do espetáculo. Rio de Janeiro, Garamond, 2004 p $185-202$

COSTA, J . F. O dec línio do comprador, ascensão do consumidor. In O vestígio e a aura: corpo e consumismo na moral do espetáculo. Rio de Janeiro, Garamond, 2004 p $131-184$ 
COX, H. A Cidade do homem (a secularização e a urbanização na perspectiva teologica). Rio de J a neiro: Paz e Terra, 1971

CRAWFORD, M. Bluming the Boundaries: public space ad private life. In Everyday Urba nism. New York: Mona celli Press, 1999 p 23

CUFF, D. Immanent domain: Pervasive Computing and the public realm. J oumal of architectural education, 2003 p 43-49

DAMIANI, A. L As contradições do espaço : à (lógica) dialética, a propósito do espaço. São Paulo : Contexto, 1999

DAMIANI, A. L Cidade (des) ordenada e o cotidiano. Revista do Departamento de Geografia Sa o Paulo, n.9 , p.107-16, 1995

DAMIANI, A. L Lugare a produção do cotidiano. São Paulo : Contexto, 1999

DELG ADO, M. Tránsitos. Espacio público, masas corpóreas. La interpreta ción del mundo: cuestiones para el tercer milenio / coord. por Patxi Lanceros, Andrés Ortiz-O sés, 2006, ISBN 84-7658-769-4, p 113-132

DEUTSCHE, R. Agoraphobia e Uneven Development public art in New York City. in 'Evic tions, Art and Spatial Politics'. Cambridge: MITPress, p. 3-52, p. 269316, 1996

DEUTSC HE, R. Evictions. Art and Spatial Politics. Massa c husetts, MITPress, 1996.

DEUTSCHE, R. The question of public space. URL: www.thephotographyinstitute.org/joumals/1998/rosalyn_deutsc he. Visita do em outubro de 2006

DILNOT, $C$. The Decisive Text on begining to read Heidegger's Building, Dwelling and Thinking. in The Harvard Architectural Review. New York, num 08, p. 161-187, 1992

FEATHERSTO NE, M. Cultura de Consumo e Pós-Modemismo. São Paulo: Studio Nobel, 1995

FEATHERSTO NE, M. Cultura Global. Petrópolis: Vozes, 1990

FEATHERSTO NE, M. 0 desmanche da cultura: globalização, pós-modemidade e identidade. São Paulo: Studio Nobel, Sesc, 1997

FERRARA, L. D. Architectures de l'espace. Paris: L'Harmatta n, 2001 
FERRARA, L D. Arquitetura e Linguagem: Investigação Contínua. In: Ana Clá udia Oliveira. (Org.). Visualidade Urbanidade Intertextualidade. 1a ed. São Paulo: Hecker, 1998, v. 1, p 25-32

FERRARA, L D. Lugar na cidade : conhecimento e diálogo. Campinas: Edições Teritorial, 2003 p 118-129

FIG UERA, D. R. A efetividade do projeto de cidade ecológica de palmas - to: pelos seus espaços verdes. Dissertação de Mestrado em Ciências do Ambiente - UFT, Palmas, 2005

FOUCAULT, M. Of other Spaces: utopias and heteretopias. in Lea ch, N. (editor) 'Rethinking Arc hitecture'. New York: Routledge, p. 350-379, 1997

FRENCH, J. S. Urban Space: a brief history of the city. Dubuque: Fendall Hunt, 1978

FRÚGOU J r., H. São Paulo: espaços públicos e interação social. São Paulo: Marco Zero, 1995

GAETA, A. C. Acumulação e transformação do espaço urbano. São Paulo, 1988

GIANG REG ORIO, G. Crútica e Projecto na Cidade Contemporãnea. in ECDJ : Novos Mapas para Velhas Cidades. Coimbra, n 03, 2000

GOMES, P. C. da C. A condição urbana: ensaios de geopolítica da cidade. Rio de J a neiro: Bertrand Brasil, 2002

GOTIDIENER, M. A produção social do espaço urbano. São Paulo: Edusp, 1993

G REG ORY, D. Social relations and spatial structures. Lond on: Ma c millan, 1990. GUATTARI, F. As três ecologias. Campinas: Pa pinus, 1990

GUIHEUX, A. Libelo por una ciudad contemporánea suntuosa. In: DETHIER, Jean \& GUIHEUX, Alain. La Ville: Art et Architecture en Europe - 1870-1993. Paris: Centre Georges Pompidou, 1994

HAШ, E. T. Dimensão oculta. Madrid: Leal, 1973

HAШ, P. Cidades do amanhã. Perspectiva, Sã o Pa ulo, 1995

HARVEY, D. A condição pós-modema: uma mudança sobre as origens da mudança cultural. São Paulo: Loyola, 1993 
HEIDEGGER, M. Construir, habitar, pensar. In Conferencias y a rtículos. Barcelona: Ediciones del Serbal, 1994

HILUER, B. The Common language of space. http://www.spacesyntax.org, visita do em junho de 2006

HILUER, B. The social logic of space. Cambridge: Cambridge University Press, 1988

HOLANDA, F. (organizador) Arquitetura e Urbanidade. São Paulo: PróEditores Associados Ltda., 2003

HOLANDA, F. Notas de a ula. Mestrado interinstituc ional UNB-UFT. Pa Imas, 2007 HOUGH, M. Naturaleza y Ciudad: planificación urbana y procesos ecológic os. Barc elona: Gusta vo G ili, 1995

HOUGH, M. Out of Place: Restoring Identity to the Regional Landscape. New Haven: Yale University Press, 1990

HUET, B. A Cidade como Espaço habitável: altemativas à Carta de Atenas. in Arquitetura e Urba nismo. São Paulo: DezlJ an 86/87, p. 82-87, 1987

HUET, Bema rd. Espaços públic os, espaços residuais. In: HUET, Bema rd et al. Os Centros das Metrópoles: reflexões e propostas para a cidade democrática do século XXI. São Paulo: Terceiro Nome/Viva o Centro/Imprensa Oficial, 2001 p 147-151

J ACKSO N, J . B. A sense of place, a sense of time. New Ha ven: Yale University, 1994

J ACOBS, J . Morte e vida das grandes cidades. Martins Fontes, Sã o Pa ulo, 2000 J AMESO N, F. Espaço e imagem: teorias do pós-modemo e outros ensaios. Rio de J a neiro: Editora UFRJ , 2004

J AMESON, F. Pos-modemismo: a lógica cultural do capitalismo tardio. São Paulo : Atica, 1996

J AMESON, F.. Pós-modemidade e sociedade de consumo. In: Revista Novos Estudos CEBRAP. Sã o Pa ulo, nำ12, 1985, p 16-26

KATZ, P. The New Urbanism: Toward arc hitec ture of community. EUA, 1994 KOHLSDORF, M. E. - A apreensão da forma da cidade. UNB: Bra sília, 1996 LAMAS, J. M. R. G. Morfologia urbana e desenho da cidade. Lisboa: Fundação Calouste Gulbenkian, 1993 
LFFEBVRE, H. A Produção do Espaço. Cap. VI - Das Contra dições do espaço diferencial - Tra d. J orge Hajime Oseki, 2003

LFFEBVRE, H. Vida cotidiana no mundo modemo. Sã o Pa ulo: Ática, 1991

LFITÃO, L A dimensão subjetiva da sustentabilidade. In: II Seminá rio Intemacional de Conservação e desenvolvimento sustentável urbano. Uma estrutura teórica. CECI/UFPE, IPHAN, WHC/UNESCO, ICCRON, OVPM, ICOMOS/CIF, Recife, 1998

LEITE, M. A. F. P. Destruição ou desconstrução? São Paulo: Hucitec, 1994

LEITE, M. Â. F. P. Mas, se o lugar nos engana, é por conta do mundo. São Paulo: Fundação Perseu Abramo, 2004

LEITE, M. A. F. P. Novos valores : destruição ou desconstrução? questões da paisagem e tendências de regionalização. Tese Doutora do. São Paulo, 1992 LEITE, M. A. F. P. Os lugares invisíveis. Revista paisa gem e ambiente $n^{\circ} 11$. São Paulo: FAU-USP, 1997

LFITE, M. A. F. Projeto e uso dos espaços públicos, o código e interpretação. São Paulo : Hacker ; Centro de Pesquisa Sociossemióticas, 1998. p 65-75

LEITE, M. A. F.P. Espaço público e visibilidade social. São Pa ulo: FAUUSP, 1998 URA, E. R. - A gênese de Palmas - Tocantins. Disserta ção de Mestra do. UNESP, Presidente Prudente, 1995

URA, E. R. - A gênese de Palmas - Tocantins. Dissertação de Mestrado. Presidente Prudente; UNESP, 1995

LYNCH, K. Managing the Sense of a Region. Cambridge: The MITPress, 1978 MAGNANI, J . G. C. Na metrópole: textos de antropologia urbana. São Paulo: Edusp, 2000

MAGNANI, J. G. C. Quando o campo é a cidade: fazendo antropologia na metrópole. São Paulo: EDUSP, 1996

MAGNANI, J. G. C. Transformações na cultura urbana das grandes metrópoles. Petrópolis: Vozes, 1998

MALHEIROS, U. da S. Palmas: cidade real, cidade imaginária. Arte pública como representação urbana. São Paulo: Tese de doutorado apresentada a FAUUSP, 2002 
MARCUS, C .; C ., FRANCIS, C. People Places: design guidelines for urban open spaces. New York: Van Nostrand Reinhold, 1990

MARIANI, R. Cidade modema entre a história e a cultura. São Paulo: Nobel, 1986

MARTINS, J. de S. A sociabilidade do homem simples. São Paulo: Hucitec, 2000

MCCUШOUGH, M. Digital Ground - Architecture, Penasive Computing, and Environmental Knowing. Massa c husetts: The MITPress Cambridge, 2004

MEYER, M. R. P. Pensando a Urbanidade. Resenha, 2004

MILLER, M. Raymond Unwin: Garden cities \& town planning. Leicester, UK: Leic ester University Press, 1992

MONTANER, J M. Espacio y antiespacio, lugar y no lugar en la arquitectura modema. in 'La Modemidad Superada: arte y pensamineto del siglo XX'. Barcelona, p. 25-58, 2001

MORAES, A. C. R. Meio ambiente e ciências humanas. São Paulo: Hucitec, 1994

MORAES, L. M. A segregação planejada: Goiânia, Brasilia e Palmas. Goiânia: Editora da UCG, 2003

NASSAUER, J . Placing nature: Culture landscape ecology. Wa shington D.C.: Island Press, 1997

NEITO, V. de M. O efeito da arquitetura. IAB-RS http://iab-rs.org.br/, visita do em junho de 2006

NORBERG-SCHULZ, C. Existencia, espacio y arquitec tura. Ba rcelona, Blume, 1978

OLVEIRA, A C. M. A. de; BRITO, Y C. F. de Visualidade, Urbanidade, Intertextualidade. São Paulo: Hacker Editores, 1998

PAUL, R. E. Pattem of urban life. Longman: Ha row, 1970

PESCI, R. La Ciudad de la urbanidad. Buenos Aires: Funda c ión CEPA, 1999

RABOTNIKOF, N. E espacio público: variaciones en tomo a un concepto, en La tenacidad de la política, IIF, UNAM, 1995

RIBEIRO, A. C. T. Urbanidade e vida metropolitana. Rio de janeiro: Jobran, 1996 
SANTOS, C. N. F. dos A cidade como um jogo de cartas. Rio de J aneiro: UFF, 1988

SANTOS, C. N. F. dos Quando a nua vira casa: a apropriação de espaços de uso coletivo em um centro de baimo. Sã o Pa ulo: Ibam/finep, 1985

SANTOS, M. A natureza do espaço: técnica e tempo, razão e emoção. São Paulo: Hucitec, 1996

SANTOS, M. Espaço do cidadão. São Pa ulo: Nobel, 1993

SANTOS, M. Espaço e método. São Paulo: Nobel, 1985

SANTOS, M. Metamorfoses do espaço habitado. São Paulo, Huc itec, 1991

SANTOS, M. Pensando o espaço do homem. São Paulo: Huc itec, 1982

SAUNDERS, P. R. Social theory and the urban question. New York: Holmes \& Meier, 1981

SCHULZ, S. H. Mundos Diferenciais na cidade: a urbanidade como experiência estética. São Pa ulo, 2003

SENNETT, R. O Declínio do Homem Público. Sã o Pa ulo: Companhia das Letras, 1988

SILVA, A. C. da O espaço fora do lugar. São Pa ulo, Hucitec, 1978

SIMMEL, G. E individuo y la libertada. Ensayos de crítica de la cultura. Barcelona: Ed. Península, 1986

SING ER, P. I. Cidade e campo. São Paulo: CEBRAP, 1972

SOLA-MORALES, I. Lugar: Diferencias. Topografia de la arquitectura contemporânea. Barcelona: Gustavo Gilli, 1995

SOLÁ-MORALES, I. Presente y Futuros: arquitectura em la ciudad. Barcelona: XIX Congresso de la UIA, 1996

SOLÀ-MORALES, M. Las Fommas del Crecimiento Urbano. Barcelona: UPC , 1997 SPIRN, A. W. O jardim de granito. A natureza no desenho da cidade. São Paulo: EDUSP, 1995

TRINDADE, D. L $\mathbf{O}$ desenho urbano de Palmas. Disserta ção de Mestrado. São Carlos, 1999

TUAN, Y. Espaço e lugar: a perspectiva da experiência. São Paulo: Difel, 1983 VELHO, G. Individualismo e cultura: nota para uma antropologia da sociedade contemporânea. Rio de J a neiro: Zahar, 1981 
VELHO, O. G. O fenômeno urbano. Ed. Gua nabara, Rio de J a neiro, 1987

VIRÍLIO, P. Espaço Cń́tico. Rio de J a neiro: Ed. 34, 1993

ZUKIN, S. The culture of cities. Cambridge: Bla ckwell, 2000

Sites:

Space Syntax - www.space.synta x.org

Vitruvius - www.vitruvius.com.br

Prefeitura de Palmas - www.palmas.to.gov.br

Entrevistas:

Luis Hildebrando Ferreira Paz: 20/10/2006

Associação dos moradores da Vila União: 22/10/2006

Walfredo Antunes de Oliveira Filho: 25/10/2006

Moisés Avelino: 27/10/2006 


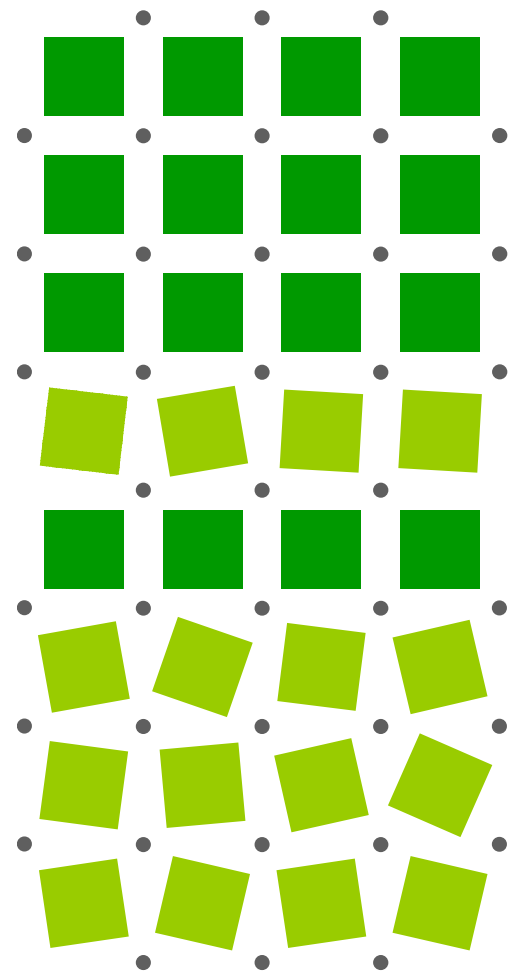

Prólogo 


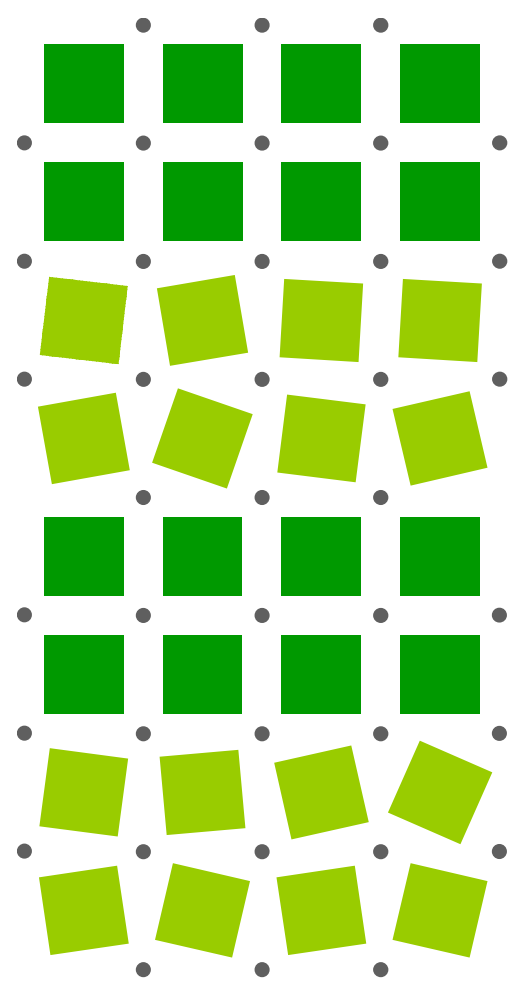

Introd uçã o 


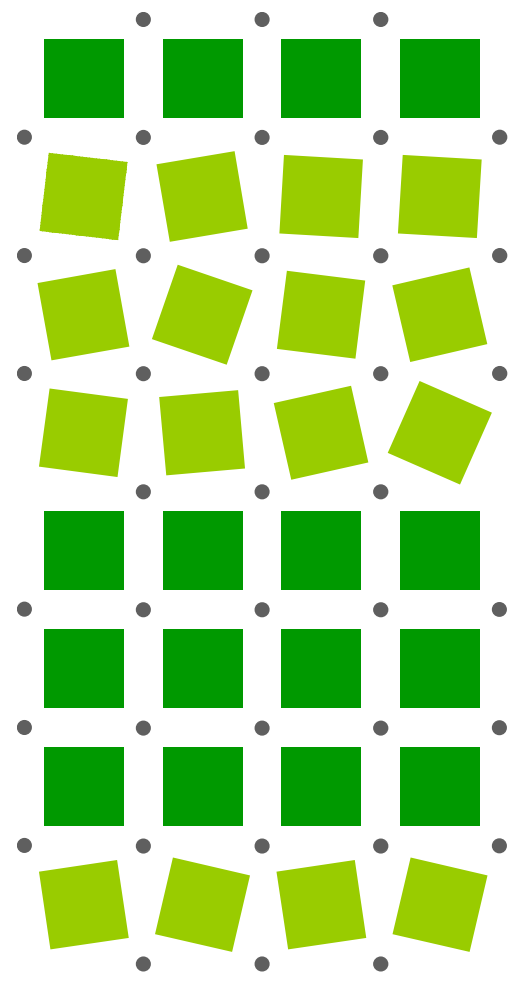

Capítulo 01: espaço, lugar e paisagem 


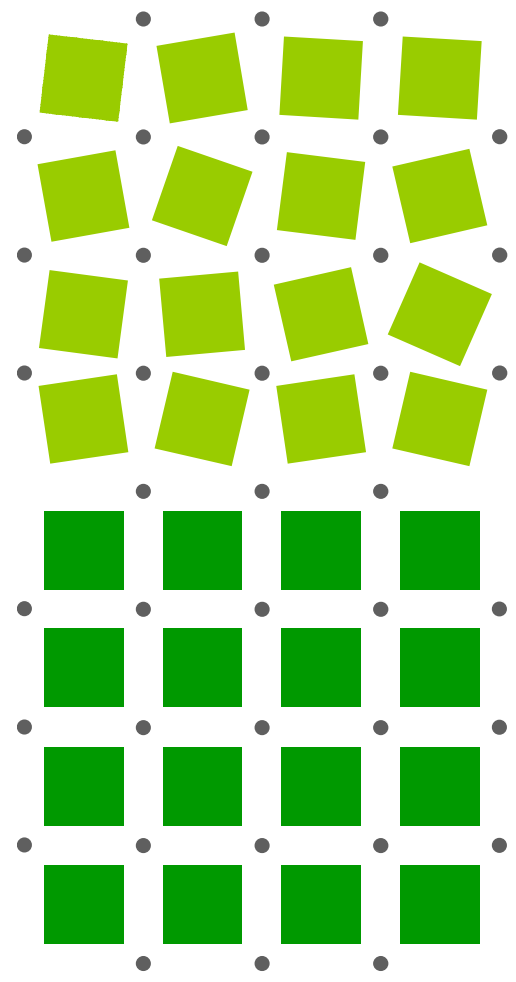

Capítulo 02: a urbanidade em questão 


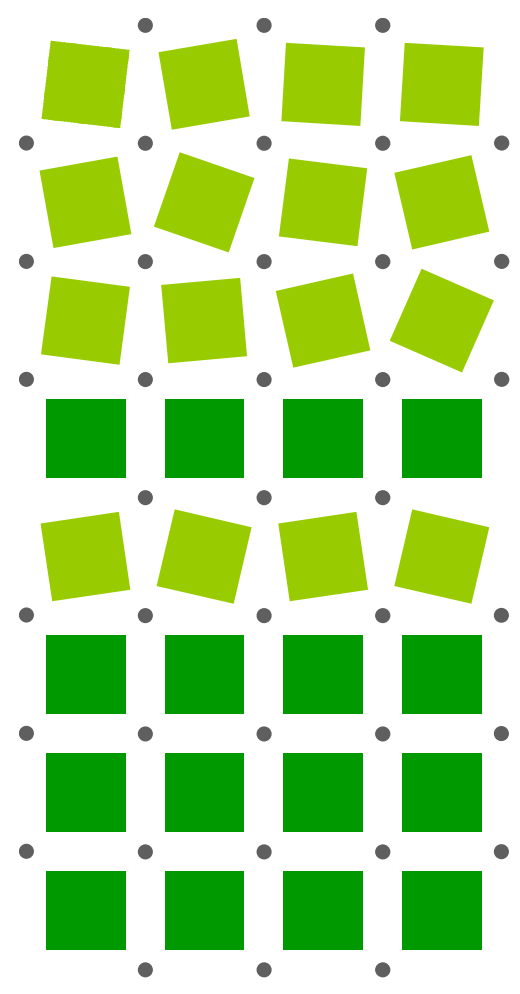

Capítulo 03: inscrições no espaço de Palmas 


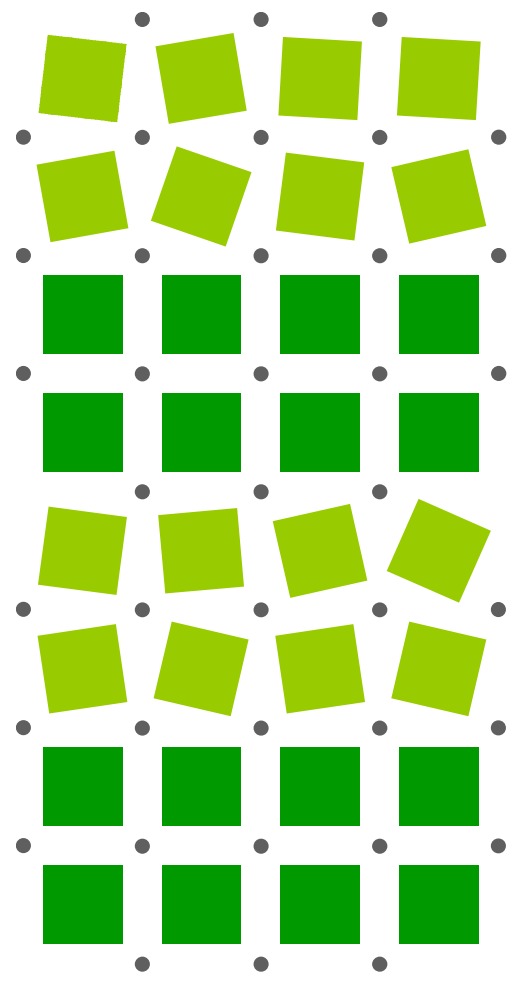

Capítulo 04: os limites do projeto urbano na conformação de lugares 


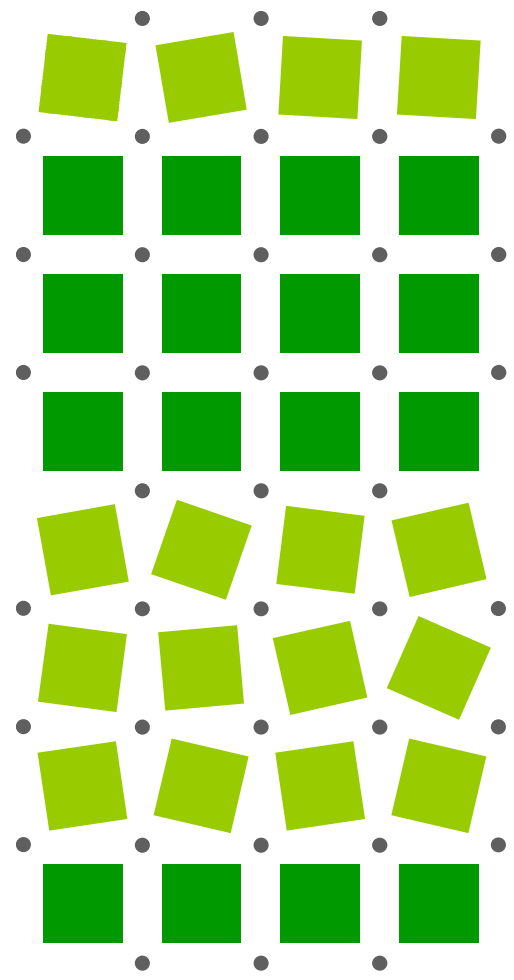

Considera ções Fina is 


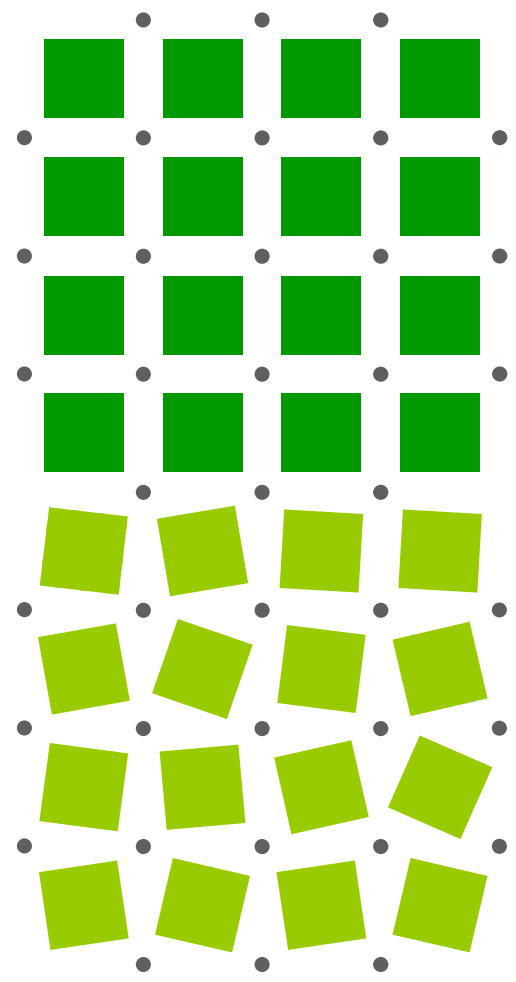

Bibliografia 
\# Paisagem e Urbanidade Glauco de Paula Cocozza 变 